\title{
Drugs for the acute treatment of migraine in children and adolescents (Review)
}

Richer L, Billinghurst L, Linsdell MA, Russell K, Vandermeer B, Crumley ET, Durec T, Klassen TP, Hartling L

Richer L, Billinghurst L, Linsdell MA, Russell K, Vandermeer B, Crumley ET, Durec T, Klassen TP, Hartling L.

Drugs for the acute treatment of migraine in children and adolescents.

Cochrane Database of Systematic Reviews 2016, Issue 4. Art. No.: CD005220.

DOI: 10.1002/14651858.CD005220.pub2.

www.cochranelibrary.com 
TABLE OF CONTENTS

HEADER 1

ABSTRACT

PLAIN LANGUAGE SUMMARY

SUMMARY OF FINDINGS

BACKGROUND

OBJECTIVES

METHODS

RESULTS

Figure 1.

Figure 2.

Figure 3.

Figure 4.

Figure 5.

Figure 6.

DISCUSSION

AUTHORS' CONCLUSIONS

ACKNOWLEDGEMENTS

REFERENCES

CHARACTERISTICS OF STUDIES

DATA AND ANALYSES

Analysis 1.1. Comparison 1: Ibuprofen vs placebo in children, Outcome 1: Pain-free

Analysis 1.2. Comparison 1: Ibuprofen vs placebo in children, Outcome 2: Adverse events (any)

Analysis 1.3. Comparison 1: Ibuprofen vs placebo in children, Outcome 3: Headache relief

Analysis 1.4. Comparison 1: Ibuprofen vs placebo in children, Outcome 4: Rescue medication

Analysis 1.5. Comparison 1: Ibuprofen vs placebo in children, Outcome 5: Headache recurrence

Analysis 2.1. Comparison 2: Triptans vs placebo in children, Outcome 1: Pain-free

Analysis 2.2. Comparison 2: Triptans vs placebo in children, Outcome 2: Adverse events (any)

Analysis 2.3. Comparison 2: Triptans vs placebo in children, Outcome 3: Headache relief

Analysis 2.4. Comparison 2: Triptans vs placebo in children, Outcome 4: Rescue medication

Analysis 2.5. Comparison 2: Triptans vs placebo in children, Outcome 5: Headache recurrence

Analysis 2.6. Comparison 2: Triptans vs placebo in children, Outcome 6: Presence of nausea

Analysis 2.7. Comparison 2: Triptans vs placebo in children, Outcome 7: Presence of vomiting

Analysis 3.1. Comparison 3: Triptans vs placebo in adolescents, Outcome 1: Pain-free

Analysis 3.2. Comparison 3: Triptans vs placebo in adolescents, Outcome 2: Adverse events (any)

Analysis 3.3. Comparison 3: Triptans vs placebo in adolescents, Outcome 3: Headache relief

Analysis 3.4. Comparison 3: Triptans vs placebo in adolescents, Outcome 4: Rescue medication

Analysis 3.5. Comparison 3: Triptans vs placebo in adolescents, Outcome 5: Headache recurrence

Analysis 3.6. Comparison 3: Triptans vs placebo in adolescents, Outcome 6: Presence of nausea

Analysis 3.7. Comparison 3: Triptans vs placebo in adolescents, Outcome 7: Presence of vomiting

Analysis 4.1. Comparison 4: Triptans vs placebo in adolescents, subgroup analysis, Outcome 1: Pain-free by route (oral or intranasal)

Analysis 4.2. Comparison 4: Triptans vs placebo in adolescents, subgroup analysis, Outcome 2: Sumatriptan vs placebo by route (oral or intranasal)

Analysis 4.3. Comparison 4: Triptans vs placebo in adolescents, subgroup analysis, Outcome 3: Zolmitriptan vs placebo by route (oral or intranasal)

Analysis 4.4. Comparison 4: Triptans vs placebo in adolescents, subgroup analysis, Outcome 4: Pain-free by preventive medication

Analysis 5.1. Comparison 5: Triptans vs placebo by age, subgroup analysis, Outcome 1: Age group

Analysis 6.1. Comparison 6: Triptans vs placebo in adolescents, sensitivity analysis, Outcome 1: Study design ...................... Analysis 6.2. Comparison 6: Triptans vs placebo in adolescents, sensitivity analysis, Outcome 2: Allocation concealment ........ Analysis 6.3. Comparison 6: Triptans vs placebo in adolescents, sensitivity analysis, Outcome 3: Source of funding ................ Analysis 6.4. Comparison 6: Triptans vs placebo in adolescents, sensitivity analysis, Outcome 4: Reported in a journal ........... 


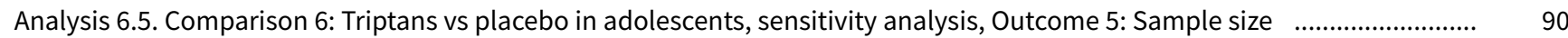

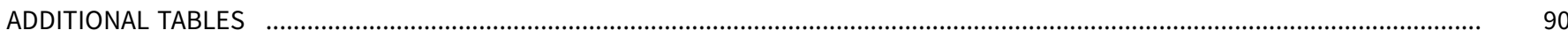

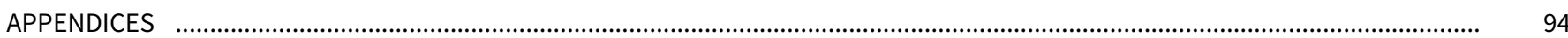

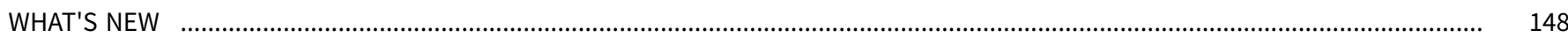

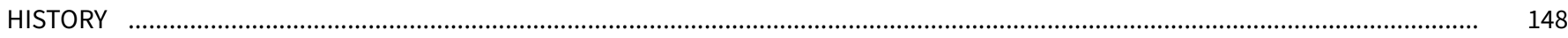

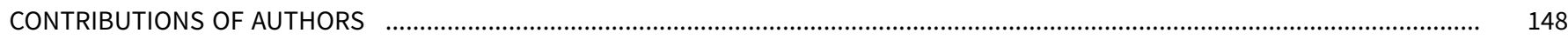

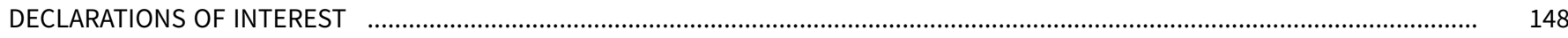

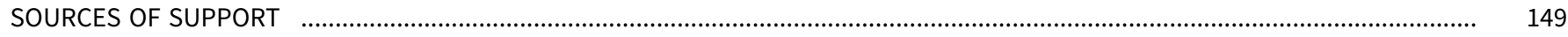

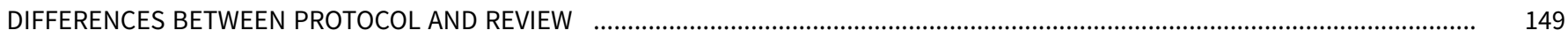

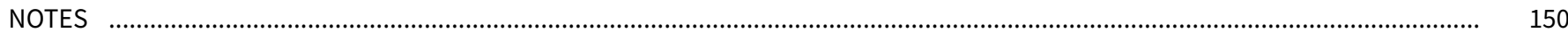

INDEX TERMS 
[Intervention Review]

\section{Drugs for the acute treatment of migraine in children and adolescents}

Lawrence Richer $^{1}$, Lori Billinghurst ${ }^{2}$, Meghan A Linsdell ${ }^{3}$, Kelly Russell ${ }^{4}$, Ben Vandermeer ${ }^{5}$, Ellen T Crumley ${ }^{6}$, Tamara Durec ${ }^{7}$, Terry P Klassen8, Lisa Hartling5

1Department of Pediatrics, Division of Neurology, University of Alberta, Edmonton, Canada. 2Division of Neurology, The Children's Hospital of Philadelphia, Philadelphia, PA, USA. 3Women and Children's Health Research Institute, University of Alberta, Edmonton, Canada. ${ }^{4}$ Department of Pediatrics and Child Health, University of Manitoba, Winnipeg, Canada. ${ }^{5}$ Department of Pediatrics and the Alberta Research Centre for Health Evidence, University of Alberta, Edmonton, Canada. 6 Health Info and Searching Practice Inc, Edmonton, Canada. ${ }^{7}$ Aberhart Centre One, Room 9418, Evidence-based Practice Centre, Edmonton, Canada. 8 Manitoba Institute of Child Health, Winnipeg, Canada

Contact address: Lawrence Richer, Iricher@ualberta.ca.

Editorial group: Cochrane Pain, Palliative and Supportive Care Group.

Publication status and date: Stable (no update expected for reasons given in 'What's new'), published in Issue 10, 2020.

Citation: Richer L, Billinghurst L, Linsdell MA, Russell K, Vandermeer B, Crumley ET, Durec T, Klassen TP, Hartling L. Drugs for the acute treatment of migraine in children and adolescents. Cochrane Database of Systematic Reviews 2016, Issue 4. Art. No.: CD005220. DOI: 10.1002/14651858.CD005220.pub2.

Copyright @ 2016 The Cochrane Collaboration. Published by John Wiley \& Sons, Ltd.

\section{A B S T R A C T}

\section{Background}

Numerous medications are available for the acute treatment of migraine in adults, and some have now been approved for use in children and adolescents in the ambulatory setting. A systematic review of acute treatment of migraine medication trials in children and adolescents will help clinicians make evidence-informed management choices.

\section{Objectives}

To assess the effects of pharmacological interventions by any route of administration versus placebo for migraine in children and adolescents 17 years of age or less. For the purposes of this review, children were defined as under 12 years of age and adolescents 12 to 17 years of age.

\section{Search methods}

We searched seven bibliographic databases and four clinical trial registers as well as gray literature for studies through February 2016.

\section{Selection criteria}

We included prospective randomized controlled clinical trials of children and adolescents with migraine, comparing acute symptom relieving migraine medications with placebo in the ambulatory setting.

\section{Data collection and analysis}

Two reviewers screened titles and abstracts and reviewed the full text of potentially eligible studies. Two independent reviewers extracted data for studies meeting inclusion criteria. We calculated the risk ratios (RRs) and number needed to treat for an additional beneficial outcome (NNTB) for dichotomous data. We calculated the risk difference (RD) and number needed to treat for an additional harmful outcome (NNTH) for proportions of adverse events. The percentage of pain-free patients at two hours was the primary efficacy outcome measure. We used adverse events to evaluate safety and tolerability. Secondary outcome measures included headache relief, use of rescue medication, headache recurrence, presence of nausea, and presence of vomiting. We assessed the evidence using GRADE (Grading of Recommendations Assessment, Development and Evaluation) and created 'Summary of findings' tables. 


\section{Main results}

We identified a total of 27 randomized controlled trials (RCTs) of migraine symptom-relieving medications, in which 9158 children and adolescents were enrolled and 7630 (range of mean age between 8.2 and 14.7 years) received medication. Twenty-four studies focused on drugs in the triptan class, including almotriptan, eletriptan, naratriptan, rizatriptan, sumatriptan, sumatriptan + naproxen sodium, and zolmitriptan. Other medications studied included paracetamol (acetaminophen), ibuprofen, and dihydroergotamine (DHE). More than half of the studies evaluated sumatriptan. All but one study reported adverse event data. Most studies presented a low or unclear risk of bias, and the overall quality of evidence, according to GRADE criteria, was low to moderate, downgraded mostly due to imprecision and inconsistency. Ibuprofen was more effective than placebo for producing pain freedom at two hours in two small studies that included 162 children (RR 1.87, 95\% confidence interval ( $\mathrm{Cl}) 1.15$ to 3.04) with low quality evidence (due to imprecision). Paracetamol was not superior to placebo in one small study of 80 children. Triptans as a class of medication were superior to placebo in producing pain freedom in 3 studies involving 273 children (RR 1.67, 95\% Cl 1.06 to 2.62, NNTB 13) (moderate quality evidence) and 21 studies involving 7026 adolescents (RR $1.32,95 \% \mathrm{Cl} 1.19$ to 1.47 , NNTB 6) (moderate quality evidence). There was no significant difference in the effect sizes between studies involving children versus adolescents. Triptans were associated with an increased risk of minor (non-serious) adverse events in adolescents (RD $0.13,95 \% \mathrm{Cl} 0.08$ to 0.18 , NNTH 8), but studies did not report any serious adverse events. The risk of minor adverse events was not significant in children (RD $0.06,95 \% \mathrm{Cl}-0.04$ to 0.17 , NNTH 17). Sumatriptan plus naproxen sodium was superior to placebo in one study involving 490 adolescents (RR $3.25,95 \% \mathrm{Cl} 1.78$ to 5.94, NNTB 6) (moderate quality evidence). Oral dihydroergotamine was not superior to placebo in one small study involving 13 children.

\section{Authors' conclusions}

Low quality evidence from two small trials shows that ibuprofen appears to improve pain freedom for the acute treatment of children with migraine. We have only limited information on adverse events associated with ibuprofen in the trials included in this review. Triptans as a class are also effective at providing pain freedom in children and adolescents but are associated with higher rates of minor adverse events. Sumatriptan plus naproxen sodium is also effective in treating adolescents with migraine.

\section{PLAIN LANGUAGE SUMMARY}

\section{Drugs for the acute treatment of migraine in children and adolescents}

\section{Background and review question}

Migraine is a painful and debilitating disorder that is common in children (under 12 years of age) and adolescents (12 to 17 years of age). Common symptoms reported during a migraine attack are headache, nausea, vomiting, and sensitivity to light and sound. Many treatments for migraine are available, of which the most common are paracetamol (also known as acetaminophen), ibuprofen and other anti-inflammatories, and triptans. Not all triptan medications are approved for use in children or adolescents, and approvals vary from country to country.

\section{Study characteristics}

In our review, we looked at 27 randomized controlled trials of drugs compared to placebo to find out which treatments were effective at providing pain freedom two hours after treatment. We also wanted to know what side effects might be caused by the treatments. A total of 7630 children received medication in the studies. The evidence is current to February 2016 . Each study had between 13 and 888 participants. Their average age was 12.9 years and ranged from 8.2 to 14.7 years. Nineteen of the studies were funded by the drug manufacturer.

\section{Key results}

Ibuprofen appears to be effective in treating children with migraine, but the evidence is limited to only two small trials. Ibuprofen is readily available and inexpensive, making it an excellent first choice for migraine treatment. Paracetamol was not shown to be effective in providing pain freedom in children, but we only found one small study. Triptans are a type of medication designed specifically to treat migraine and are often effective at providing greater pain freedom in children and adolescents. The triptans examined in children included rizatriptan and sumatriptan, while almotriptan, eletriptan, naratriptan, rizatriptan, sumatriptan, and zolmitriptan were examined in adolescents. The combination of sumatriptan plus naproxen sodium is also effective at treating adolescents with migraine. Overall, there is a risk that the triptan medications may cause minor unwanted side effects like taste disturbance, nasal symptoms, dizziness, fatigue, low energy, nausea, or vomiting. The studies did not report any serious side effects.

\section{Quality of the evidence}

The overall quality of the evidence provided by the review was moderate for the triptans, but low for paracetamol and ibuprofen, as we only identified a few studies. More studies need to look at the effects of each of the migraine treatments in children and adolescents separately. 
SUMMARY OF FINDINGS

\section{Summary of findings 1 . Should ibuprofen be used to treat children with migraine?}

Ibuprofen compared with placebo in children with migraine

Patient or population: acute treatment of migraine in children

Setting: ambulatory

Intervention: ibuprofen

Comparison: placebo

\begin{tabular}{|c|c|c|c|c|c|}
\hline \multirow[t]{2}{*}{ Outcomes } & \multicolumn{2}{|c|}{ Anticipated absolute effects ${ }^{a}(95 \% \mathrm{Cl})$} & \multirow{2}{*}{$\begin{array}{l}\text { Relative effect } \\
(95 \% \mathrm{Cl})\end{array}$} & \multirow{2}{*}{$\begin{array}{l}\text { No of participants } \\
\text { (studies) }\end{array}$} & \multirow{2}{*}{$\begin{array}{l}\text { Quality of the evi- } \\
\text { dence } \\
\text { (GRADE) }\end{array}$} \\
\hline & Response with placebo & Response with Ibuprofen & & & \\
\hline \multirow[t]{2}{*}{ Pain freedom at $2 \mathrm{~h}$} & Study population & & \multirow{2}{*}{$\begin{array}{l}\text { RR } 1.87 \\
\text { (1.15 to } 3.04 \text { ) }\end{array}$} & \multirow{2}{*}{$\begin{array}{l}125 \\
\text { (2 RCTs) }\end{array}$} & \multirow{3}{*}{$\begin{array}{l}\oplus \oplus \circ 0^{b, c} \\
\text { Low }\end{array}$} \\
\hline & 267 per 1000 & $\begin{array}{l}499 \text { per } 1000 \\
(307 \text { to } 811)\end{array}$ & & & \\
\hline Adverse events & & $(-13$ to 13$)$ & $(-0.13$ to 0.13$)$ & $(1 \mathrm{RCT})$ & \\
\hline
\end{tabular}

\section{GRADE Working Group grades of evidence}

High quality: We are very confident that the true effect lies close to that of the estimate of the effect.

Moderate quality: We are moderately confident in the effect estimate: The true effect is likely to be close to the estimate of the effect, but there is a possibility that it is substantially different.

Low quality: Our confidence in the effect estimate is limited: the true effect may be substantially different from the estimate of the effect.

Very low quality: We have very little confidence in the effect estimate: the true effect is likely to be substantially different from the estimate of effect.

Cl: confidence interval; RR: risk ratio; RD: risk difference

aThe response in the intervention group (and its 95\% confidence interval) is based on the assumed risk in the comparison group and the relative effect of the intervention (and its $95 \% \mathrm{Cl}$ ).

bIn the two studies, there were no serious risks of bias, inconsistency, indirectness, or publication bias. We downgraded quality of evidence by two levels due to very serious imprecision (small sample size, few events, and wide confidence interval).

cHigh $(\oplus \oplus)$ = further research is very unlikely to change our confidence in the estimate of effect; Moderate $(\oplus \oplus \circ)=$ further research is likely to have an important impact on our confidence in the estimate of effect and may change the estimate; Low $(\oplus \oplus \circ))=$ further research is very likely to have an important impact on our confidence in the estimate of effect and is likely to change the estimate; Very Low $(\oplus \circ) 0)=$ any estimate of effect is very uncertain. 


\begin{tabular}{|c|c|c|c|c|c|c|}
\hline \multicolumn{7}{|c|}{ Triptans compared with placebo in children with migraine } \\
\hline \multicolumn{7}{|c|}{$\begin{array}{l}\text { Patient or population: acute treatment of migraine in children } \\
\text { Setting: ambulatory } \\
\text { Intervention: triptans } \\
\text { Comparison: placebo }\end{array}$} \\
\hline \multirow[t]{2}{*}{ Outcomes } & \multicolumn{2}{|c|}{ Anticipated absolute effects ${ }^{a}(95 \% \mathrm{Cl})$} & \multirow{2}{*}{$\begin{array}{l}\text { Relative effect } \\
(95 \% \mathrm{CI})\end{array}$} & \multirow{2}{*}{$\begin{array}{l}\text { No of partici- } \\
\text { pants } \\
\text { (studies) }\end{array}$} & \multirow{2}{*}{$\begin{array}{l}\text { Quality of the } \\
\text { evidence } \\
\text { (GRADE) }\end{array}$} & \multirow[t]{2}{*}{ Comments } \\
\hline & $\begin{array}{l}\text { Response with place- } \\
\text { bo }\end{array}$ & Response with triptans & & & & \\
\hline \multirow{2}{*}{$\begin{array}{l}\text { Pain freedom at } \\
2 \mathrm{~h}\end{array}$} & Study population & & \multirow{2}{*}{$\begin{array}{l}\text { RR } 1.67 \\
\text { (1.06 to } 2.62)\end{array}$} & \multirow{2}{*}{$\begin{array}{l}345 \\
(3 \mathrm{RCTs})\end{array}$} & \multirow{3}{*}{$\begin{array}{l}\oplus \oplus \oplus O \mathrm{~b}, c \\
\text { MODERATE }\end{array}$} & \multirow{3}{*}{$\begin{array}{l}\text { Includes rizatriptan oral ( } 1 \\
\text { study) and sumatriptan by } \\
\text { nasal spray ( } 2 \text { studies) }\end{array}$} \\
\hline & 276 per 1000 & $\begin{array}{l}461 \text { per } 1000 \\
(292 \text { to } 723)\end{array}$ & & & & \\
\hline Adverse events & 176 per 1000 & $\begin{array}{l}11 \text { per } 1000 \\
(-7 \text { to } 30)\end{array}$ & $\begin{array}{l}\text { RD } 0.06 \\
(-0.04 \text { to } 0.17)\end{array}$ & $\begin{array}{l}420 \\
\text { (3 RCTs) }\end{array}$ & & \\
\hline
\end{tabular}

\section{GRADE Working Group grades of evidence}

High quality: We are very confident that the true effect lies close to that of the estimate of the effect.

Moderate quality: We are moderately confident in the effect estimate: the true effect is likely to be close to the estimate of the effect, but there is a possibility that it is substantially different.

Low quality: Our confidence in the effect estimate is limited: the true effect may be substantially different from the estimate of the effect.

Very low quality: We have very little confidence in the effect estimate: the true effect is likely to be substantially different from the estimate of effect.

CI: confidence interval; RR: risk ratio; RD: risk difference.

${ }^{a}$ The response in the intervention group (and its 95\% confidence interval) is based on the assumed response in the comparison group and the relative effect of the intervention (and its 95\% Cl).

bIn the three studies, there were no serious risks of bias, inconsistency, indirectness, or publication bias detected. Quality of evidence was downgraded by one level due to serious imprecision (small sample size, few events, and wide confidence interval).

cHigh $(\oplus)=$ further research is very unlikely to change our confidence in the estimate of effect; Moderate $(\oplus 0)=$ further research is likely to have an important impact on our confidence in the estimate of effect and may change the estimate; Low $(\oplus \circ)$ = further research is very likely to have an important impact on our confidence in the estimate of effect and is likely to change the estimate; Very Low $(\oplus 00))=$ any estimate of effect is very uncertain.

\section{Summary of findings 3 . Should triptans be used to treat adolescents with migraine?}

Triptans compared with placebo in adolescents with migraine 


\begin{tabular}{|c|c|c|c|c|c|c|}
\hline \multirow[t]{2}{*}{ Outcomes } & \multicolumn{2}{|c|}{ Anticipated absolute effects ${ }^{a}(95 \% \mathrm{Cl})$} & \multirow{2}{*}{$\begin{array}{l}\text { Relative effect } \\
(95 \% \mathrm{Cl})\end{array}$} & \multirow{2}{*}{$\begin{array}{l}\text { No of partici- } \\
\text { pants } \\
\text { (studies) }\end{array}$} & \multirow{2}{*}{$\begin{array}{l}\text { Quality of the } \\
\text { evidence } \\
\text { (GRADE) }\end{array}$} & \multirow[t]{2}{*}{ Comments } \\
\hline & $\begin{array}{l}\text { Response with } \\
\text { placebo }\end{array}$ & Response with Triptans & & & & \\
\hline \multirow{2}{*}{$\begin{array}{l}\text { Pain freedom at } \\
2 \mathrm{~h}\end{array}$} & Study population & & \multirow{2}{*}{$\begin{array}{l}\text { RR } 1.32 \\
\text { (1.19 to } 1.47 \text { ) }\end{array}$} & \multirow{2}{*}{$\begin{array}{l}6761 \\
\text { (21 RCTs) }\end{array}$} & \multirow{4}{*}{$\begin{array}{l}\text { MOD,c } \\
\text { MODERATE }\end{array}$} & \multirow{4}{*}{$\begin{array}{l}\text { Includes almotriptan (1 study), eletriptan } \\
\text { (1 study), naratriptan (1 study), rizatriptan } \\
\text { (4 studies), sumatriptan (10 studies), and } \\
\text { zolmitriptan (4 studies) }\end{array}$} \\
\hline & 230 per 1000 & $\begin{array}{l}303 \text { per } 1000 \\
\text { (273 to } 338)\end{array}$ & & & & \\
\hline \multirow[t]{2}{*}{ Adverse events } & 184 per 1000 & 24 per 1000 & RD 0.13 & 7876 & & \\
\hline & & (15 to 33 ) & (0.08 to 0.18$)$ & (21 RCTs) & & \\
\hline
\end{tabular}

\section{GRADE Working Group grades of evidence}

High quality: We are very confident that the true effect lies close to that of the estimate of the effect.

Moderate quality: We are moderately confident in the effect estimate: the true effect is likely to be close to the estimate of the effect, but there is a possibility that it is sub-

stantially different.

Low quality: Our confidence in the effect estimate is limited: the true effect may be substantially different from the estimate of the effect.

Very low quality: We have very little confidence in the effect estimate: the true effect is likely to be substantially different from the estimate of effect.

Cl: confidence interval; RR: risk ratio; RD: risk difference.

aThe response in the intervention group (and its 95\% confidence interval) is based on the assumed response in the comparison group and the relative effect of the intervention (and its $95 \% \mathrm{Cl}$ ).

bSerious inconsistency was observed in the effect estimates. All of the triptans with only 1 study were not statistically superior to placebo (i.e. almotriptan, eletriptan, naratriptan) in producing pain freedom while the three triptans with 2 or more studies (i.e. rizatriptan, sumatriptan, and zolmitriptan) were statistically significant with a higher magnitude of effect. In the subgroup analysis of the individual triptan groups through, the subgroup differences were not statistically significant $(\mathrm{P}=0.45)$.

cHigh $(\oplus)=$ further research is very unlikely to change our confidence in the estimate of effect; Moderate $(\oplus \oplus 0)=$ further research is likely to have an important impact on our confidence in the estimate of effect and may change the estimate; Low $(\oplus \oplus \circ))=$ further research is very likely to have an important impact on our confidence in the estimate of effect and is likely to change the estimate; Very Low $(\oplus \circ) 0)=$ any estimate of effect is very uncertain.

\section{Summary of findings 4 . Should sumatriptan plus naproxen sodium be used to treat adolescents with migraine?}

Sumatriptan + naproxen sodium compared with placebo in adolescents with migraine

Patient or population: acute treatment of migraine in adolescents

Setting: ambulatory 
Intervention: sumatriptan + naproxen sodium Comparison: placebo

\begin{tabular}{|c|c|c|c|c|c|c|}
\hline \multirow[t]{2}{*}{ Outcomes } & \multicolumn{2}{|c|}{ Anticipated absolute effects ${ }^{a}(95 \% \mathrm{Cl})$} & \multirow{2}{*}{$\begin{array}{l}\text { Relative effect } \\
(95 \% \mathrm{Cl})\end{array}$} & \multirow{2}{*}{$\begin{array}{l}\text { No of partici- } \\
\text { pants } \\
\text { (studies) }\end{array}$} & \multirow{2}{*}{$\begin{array}{l}\text { Quality of the } \\
\text { evidence } \\
\text { (GRADE) }\end{array}$} & \multirow[t]{2}{*}{ Comments } \\
\hline & $\begin{array}{l}\text { Response with } \\
\text { placebo }\end{array}$ & $\begin{array}{l}\text { Response with Sumatrip- } \\
\tan +\text { naproxen sodium }\end{array}$ & & & & \\
\hline \multirow{2}{*}{$\begin{array}{l}\text { Pain freedom at } \\
2 \mathrm{~h}\end{array}$} & Study population & & \multirow{2}{*}{$\begin{array}{l}\text { RR } 2.66 \\
\text { (1.57 to } 4.51)\end{array}$} & \multirow{2}{*}{$\begin{array}{l}485 \\
(1 \mathrm{RCT})\end{array}$} & \multirow{4}{*}{$\begin{array}{l}\oplus \oplus O^{b, c} \\
\text { MODERATE }\end{array}$} & \multirow{4}{*}{$\begin{array}{l}\text { Doses including sumatriptan + naproxen } \\
10 \mathrm{mg}+60 \mathrm{mg}, 30 \mathrm{mg}+180 \mathrm{mg} \text {, and } 85 \\
\mathrm{mg}+500 \mathrm{mg} \text { were all well tolerated and } \\
\text { demonstrated similar efficacy }\end{array}$} \\
\hline & 99 per 1000 & $\begin{array}{l}262 \text { per } 1000 \\
\text { (163 to } 394)\end{array}$ & & & & \\
\hline \multirow[t]{2}{*}{ Adverse events } & 83 per 1000 & 2 per 1000 & RD 0.03 & 490 & & \\
\hline & & $(-2$ to 7$)$ & $(-0.02$ to 0.09$)$ & $(1 \mathrm{RCT})$ & & \\
\hline
\end{tabular}

\section{GADE Working Group grades of evidence}

High quality: We are very confident that the true effect lies close to that of the estimate of the effect.

Moderate quality: We are moderately confident in the effect estimate: the true effect is likely to be close to the estimate of the effect, but there is a possibility that it is substantially different.

Low quality: Our confidence in the effect estimate is limited: the true effect may be substantially different from the estimate of the effect.

Very low quality: We have very little confidence in the effect estimate: the true effect is likely to be substantially different from the estimate of effect.

Cl: confidence interval; RR: risk ratio; RD: risk difference.

aThe response in the intervention group (and its 95\% confidence interval) is based on the assumed response in the comparison group and the relative effect of the intervention (and its $95 \% \mathrm{Cl}$ ).

bThe confidence interval of the effect size is wide. The true effect may be substantially different than the estimated effect in producing pain freedom.

cHigh $(\oplus \oplus)=$ further research is very unlikely to change our confidence in the estimate of effect; Moderate $(\oplus \oplus)=$ further research is likely to have an important impact on our confidence in the estimate of effect and may change the estimate; Low $(\oplus \oplus \circ))$ f further research is very likely to have an important impact on our confidence in the estimate of effect and is likely to change the estimate; Very Low $(\oplus \circ) 0)=$ any estimate of effect is very uncertain. 


\section{B A C K G R O U N D}

Migraine is a common and disabling disease, affecting 3\% to $10 \%$ of children and adolescents (Stovner 2007). Children as young as two years of age may be affected, and most adults with migraine have their first headache in early childhood or adolescence (Bille 1997). Quality-of-life studies indicate that migraine has a significant negative impact on a child (Powers 2003; Powers 2004). Indeed, migraines can be a tremendous source of anxiety for children, adolescents, and their parents, disrupting both school obligations and parental work responsibilities. These concerns may be amplified when there is uncertainty on the physician's part as to the best treatment.

The International Classification of Headache Disorders, 3 rd edition, beta version (ICHD-3 beta), provides the most accepted and current definition of migraine. The presence of headache, often associated with nausea, vomiting, or both is common to adults, adolescents, and children with migraine. However, the criteria acknowledge that children and adolescents' migraines may be shorter but will last at least two hours, and the pain may be bilateral over the frontotemporal head regions or non-pulsatile. Adolescents, like adults, will usually begin to report unilateral pulsatile pain. The presence of photophobia and phonophobia may need to be inferred from behaviour such as a preference for a quiet and dimly lit room during a migraine attack.

Treatments for migraine include symptom-relieving and preventive strategies. Preventive medications are used to reduce the frequency and severity of migraine attacks. Symptom-relieving therapies commonly aim to eliminate head pain and reduce the symptoms associated with migraine, including nausea, phonophobia, and photophobia. Oral analgesics such as paracetamol and ibuprofen are the mainstay of acute therapy for migraine in children and adolescents (Hämäläinen 2002). However, other agents such as ergot derivatives (e.g. dihydroergotamine) and the serotonin $1 \mathrm{~b} / 1 \mathrm{~d}$ receptor agonists (triptans) have demonstrated efficacy in adults. Many of these medications have now been studied in children and adolescents, and some are approved for use in the pediatric age group. A practice parameter on this topic has been published by the American Academy of Neurology Quality Standards Subcommittee and the Practice Committee of the Child Neurology Society (Lewis 2004). This systematic review will summarize and update the evidence base and provide a metaanalysis of the data.

\section{O B J E C T IVES}

To assess the effects of pharmacological interventions by any route of administration versus placebo for migraine in children and adolescents 17 years of age or less. For the purposes of this review, children were defined as under 12 years of age and adolescents 12 to 17 years of age.

\section{METHOD S}

\section{Criteria for considering studies for this review}

\section{Types of studies}

We included all prospective, placebo-controlled trials of pharmacological interventions for symptomatic or acute treatment of migraine in children and adolescents in the outpatient setting if allocation to treatment groups was randomized (see Differences between protocol and review). We included studies regardless of design (i.e. parallel-group or cross-over), publication status, or language of publication. We included cross-over studies, as migraine is an episodic disorder, and we did not expect any carry-over or period effects (see Differences between protocol and review). We excluded non-placebo-controlled studies, concurrent cohort comparisons and other quasi- or non-experimental designs.

\section{Types of participants}

We included studies involving pediatric participants 17 years of age or less with a diagnosis of migraine with or without aura. For the purposes of the review, we defined children as under 12 years of age and adolescents as 12 to 17 years of age (see Differences between protocol and review). We recorded inclusion age criteria, including median and mean age of subjects. We excluded studies involving both pediatric and adult patients unless they reported results separately for the pediatric patients. We analyzed separately the data from studies that included both children and adolescents when possible. If studies did not report the data separately, we used the mean age as a surrogate. If the mean age in the study was less than 12 years, we considered the study population to be of predominantly childhood age. If the mean age was greater than or equal to 12 years, we considered the study population to be of predominantly adolescent age.

Migraine is defined by clinical symptoms and signs in the $3^{\text {rd }}$ edition of the International Classification of Headache Disorders, beta version (ICHD-3 beta). ICHD-3 beta includes revised comments for the diagnosis of migraine in children and adolescents, including shorter duration of headache ( 2 to 72 hours), bilateral frontotemporal location, and the presence of photophobia and phonophobia as inferred from behaviour. There have been two other versions of the International Classification of Headache Disorder and a proposed revision of the 1988 criteria in the context of children or adolescents (IHS 1988; ICHD-2; Winner 1995). We included a study in this review if investigators used any version of the International Headache Society classification systems above or the proposed revision for pediatrics for the diagnosis of migraine with or without aura.

\section{Types of interventions}

We included studies allocating participants to receive a pharmacological intervention by any route of administration for symptomatic acute treatment of a migraine attack. Acceptable comparator groups included placebo or other active drug treatments. We identified the use of preventive medication and examined this in subgroup analysis, but discontinuation was not required for inclusion.

\section{Types of outcome measures}

We chose outcomes to assess both efficacy and safety. We selected the primary efficacy outcome based on the suggested guidelines for controlled trials of drugs in migraine (Tfelt-Hansen 2012). The primary outcome for safety was based on the report of adverse events. All outcome measures were reported for the treatment of a single attack (see Differences between protocol and review).

\section{Primary outcomes}

The primary outcome measure for efficacy was the percentage of pain-free participants at two hours; we defined pain freedom as the absence of pain at two hours before the use of additional or 
rescue medication (see Differences between protocol and review). Headache relief is a frequently used primary outcome measure that is variably defined based on the scale used to assess pain. For example, if using the four level scale of none, mild, moderate, or severe pain, investigators or physicians may define headache relief as a decrease in pain from moderate or severe to mild or none. Some in the migraine research community have challenged the use of headache relief as a primary outcome measure; for example, migraine sufferers generally do not consider headache relief a success and expect pain freedom from an intervention (Davies 2000; Lipton 2002). Given these considerations, we classified headache relief as a secondary outcome measure (see Differences between protocol and review).

We used the percentage of participants with any adverse event(s) as the primary safety outcome measure, and this was required for inclusion in the analysis (see Differences between protocol and review). We defined adverse events as any unwanted effect that occurred during treatment. We also documented the proportion of participants reporting any serious adverse events when possible. Serious adverse events included death, any lifethreatening condition, hospitalization, disability or permanent damage, required intervention to prevent permanent damage, or any other important medical event that could jeopardize the participant or require medical or surgical intervention.

Some aspects of the original protocol were not necessary to implement given the way studies reported outcome data. We document these considerations in the Differences between protocol and review section.

\section{Secondary outcomes}

We assessed the following secondary outcome measures.

- Headache relief (headache response): the percentage of participants with headache relief at two hours is typically defined as a decrease in headache intensity from severe or moderate to mild or none at two hours prior to the use of rescue medication. When studies used alternate definitions of pain intensity (e.g. numerical scale), they needed to describe a level of relief that would be meaningful to a participant and to reflect a decrease in headache intensity similar to that assumed in the above definition.

- Rescue medication: the percentage of participants taking rescue medication at two hours or earlier to a maximum of six hours after the test drug. The definition of rescue medication was variable and often included any use of medication to treat the recurrence of headache within a specified timeframe (i.e. usually 24 hours). For the purposes of the review, rescue medication was defined as the use of any medication between 2 and 24 hours.

- Headache recurrence: the percentage of participants who were initially pain-free or achieved the study primary outcome of headache relief within 2 hours without the use of rescue medication but who experienced recurrence of any headache from 2 to 48 hours.

- Presence of nausea: percentage of participants with nausea at two hours after taking the test drug.

- Presence of vomiting: percentage of participants with vomiting within two hours of taking the test drug.

We did not include participant preference, presence of photophobia, or presence of phonophobia in the analysis as originally planned in the protocol (see Differences between protocol and review).

\section{Search methods for identification of studies}

We conducted a search of electronic databases in collaboration with a research librarian using search strategies to identify the highest level of evidence for the topic. In addition, we manually searched other sources listed below.

\section{Electronic searches}

We systematically searched the following databases:

- Cochrane Central Register of Controlled Trials (CENTRAL) (1991 to 2013, Issue 3).

- OvidSP MEDLINE (1946 to February 2016).

- Ovid MEDLINE In-Process \& Other Non-Indexed Citations (2012 to February 2016).

- EMBASE (1980 to February 2016).

- Database of Abstracts and Reviews of Effects (1991 to April 2013).

- International Pharmaceutical Abstracts (1970 to April 2013).

- PsycINFO (1806 to April 2013).

- EBSCOhost CINAHL (Cumulative Index of Nursing and Allied Health) (1937 to April 2013).

The search strategies used a combination of text words and medical subject headings (MeSH), adapted for each database searched: concepts included migraine, headache, cephalgia or cephalalgia, drug therapy, drug treatment, antimigraine therapy, antimigraine treatment, and treatment outcome, combined with drugs and acute treatments known to be used for migraine in children and adolescents. These terms were combined with a pediatric filter designed by the librarian (Lisa Tjosvold) of the Cochrane Child Health Field.

Complete search strategies are given in Appendix 1.

\section{Searching other resources}

We conducted a gray literature search including reviewing the reference lists of included studies and handsearching meeting abstracts from the American Headache Society and International Headache Society Scientific meetings. The review authors attempted to contact primary authors, experts in the area, and drug manufacturers (GlaxoSmithKline, AstraZeneca, Ortho-McNeil, Merck, and Pfizer) for information on recent, ongoing, or unpublished trials. We searched ClinicalTrials.gov for new or ongoing studies and used Current Controlled Trials (www.controlled-trials.com) to search across multiple trial registries. GlaxoSmithKline (www.gsk-clinicalstudyregister.com) and AstraZeneca (www.astrazenecaclinicaltrials.com) have clinical trial registries and report on both published and unpublished studies.

\section{Data collection and analysis}

\section{Selection of studies}

We identified potentially relevant articles by reviewing the titles and abstracts from the original search. We considered studies with insufficient information in the title or abstract as potentially relevant articles for further assessment. We then reviewed the full text of potentially relevant studies for inclusion or exclusion. 
Two reviewers independently carried out both steps. A third, independent reviewer resolved any disagreements that arose between them.

\section{Data extraction and management}

One reviewer used a standardized data abstraction form to extract data, which a second reviewer then checked for accuracy and completeness. We recorded extracted data in Review Manager 5 (RevMan 2014). A third, independent reviewer resolved discrepancies.

\section{Assessment of risk of bias in included studies}

Two reviewers assessed risk of bias using the 'Risk of bias' table for each study. Reviewers assessed five domains before making a judgement: sequence generation, allocation concealment, blinding, incomplete outcome data, and selective reporting (Higgins 2011). We resolved any disagreements by discussion. We did not use the Jadad scale as planned in the protocol, as per current recommendations of the Cochrane Collaboration (Differences between protocol and review).

\section{Assessment of quality of evidence in included studies}

We assessed the overall quality of the evidence for each outcome using the GRADE system and included our assessment in the 'Summary of findings' tables in order to present the main findings of the review in a transparent and simple tabular format (GRADEPro 2015). In particular, we included key information concerning the quality of evidence, the magnitude of effect of the interventions examined, and the sum of available data on the main outcomes.

The GRADE system uses the following criteria for assigning a level of evidence.

- High: further research is very unlikely to change our confidence in the estimate of effect.

- Moderate: further research is likely to have an important impact on our confidence in the estimate of effect and may change the estimate.

- Low: further research is very likely to have an important impact on our confidence in the estimate of effect and is likely to change the estimate.

- Very low: any estimate of effect is very uncertain.

We decreased the grade if we found:

- serious $(-1)$ or very serious $(-2)$ limitations to study quality;

- important inconsistency(s) (-1);

- some $(-1)$ or major (-2) uncertainty about directness;

- imprecise or sparse data $(-1)$;

- high probability of reporting bias $(-1)$.

\section{'Summary of findings' table}

We decided post hoc to include four 'Summary of findings' tables to present the main findings in a transparent and simple tabular format. In particular, we included key information concerning the quality of evidence, the magnitude of effect of the interventions examined, and the sum of available data on the outcomes pain freedom at 2 hours and adverse events, for the four main comparisons.

\section{Measures of treatment effect}

We reported the risk ratio (RR) for all primary and secondary efficacy outcome measures with $95 \%$ confidence intervals (Cls) as well as the number needed to treat for an additional beneficial outcome (NNTB). We reported the risk difference (RD) with 95\% Cls for the adverse events as the primary measure of harm as well as the number needed to treat for an additional harmful outcome (NNTH).

\section{Unit of analysis issues}

We included cross-over trials with binary outcomes in the analysis (Curtin 2002). None of the cross-over trials reported any significant carry-over or period effects, and none would be expected based on the acute episodic nature of migraine.

\section{Dealing with missing data}

We only analyzed the available data for all outcomes. We assessed the possibility of missing studies as described below (see Assessment of reporting biases). We considered variability in the reporting of outcomes to be random.

\section{Assessment of heterogeneity}

We assessed heterogeneity using the $\mathrm{I}^{2}$ statistic. We interpreted the $1^{2}$ statistic as suggested in the Cochrane Handbook for Systematic Reviews of Interventions (Higgins 2011).

\section{Assessment of reporting biases}

We assessed reporting biases qualitatively by visually examining the funnel plot and quantitatively using a modified version of Egger's test (Egger 1997; Harbord 2006), as implemented in the metabias module for Stata statistical software package on the triptan versus placebo studies in adolescents using the pain-free outcome (Stata 14).

\section{Data synthesis}

We pooled studies using a Mantel-Haenszel, random-effects model. We pooled dichotomous outcomes, and calculated RRs with $95 \%$ $\mathrm{Cls}$. We calculated the number needed to treat for an additional beneficial outcome (NNTB) for RRs of the primary outcome that were statistically significant. For adverse events, we combined data combined using RDs with $95 \% \mathrm{Cls}$. We calculated the number needed to treat for an additional harmful outcome (NNTH) for RDs of adverse events that were statistically significant. We included studies with small sample sizes and imprecise effect estimates, but we graded them lower for quality and weighted them accordingly in the meta-analyses.

We combined trials of cross-over design with parallel group trials in the meta-analysis. We included outcome measures from each intervention period in the analysis as if the trial were a parallel group trial. We also included three-way cross-over studies with two intervention periods and one placebo period as if they were a parallel group trial, but we divided the placebo period in two to avoid double counting the placebo interventions. Paired analysis was not possible for any of the included studies (see Differences between protocol and review). This method of including crossover studies will tend to produce wider confidence intervals and is considered a more conservative assessment of treatment effect given that these studies will receive a lower weight in the metaanalyses. We included study design in the sensitivity analysis to assess the influence of cross-over design on our final conclusions. 


\section{Subgroup analysis and investigation of heterogeneity}

We used the 12 statistic to determine the presence of heterogeneity and test for subgroup differences as implemented in RevMan, used to prepare this review (Higgins 2002; RevMan 2014). We performed all subgroup analyses for the pain-free outcome measure using the placebo-controlled studies of triptan medications versus placebo in adolescents (except for the age-based subgroup analysis).

Post hoc subgroup analyses included the following.

1. Intranasal route.

2. Preventive medication permitted during the study.

\section{Sensitivity analysis}

We examined potential sources of heterogeneity using the following a priori sensitivity analyses (see Differences between protocol and review).

1. Allocation concealment (low, unclear, or high risk of bias).

2. Cross-over versus parallel-group study design.

3. Source of funding (pharmaceutical, non-pharmaceutical, or unclear).
4. Reported in a peer-reviewed indexed journal.

5. Small sample size $\leq 50$.

We performed all sensitivity analyses for the pain-free primary outcome using the studies of triptan medications versus placebo in adolescents.

\section{RE S U L T S}

\section{Description of studies}

See Characteristics of included studies, Characteristics of excluded studies, Characteristics of ongoing studies.

\section{Results of the search}

The literature search and review of the gray literature yielded 15,811 unique citations, 379 of which we assessed as full-text articles for eligibility. Some of our data requests to manufacturers were met with referrals to trial registry websites or data were not made available. A total of 27 randomized placebo-controlled trials of acute drug therapy for migraine met our inclusion criteria (Figure $1)$. 
Figure 1. Study flow diagram.

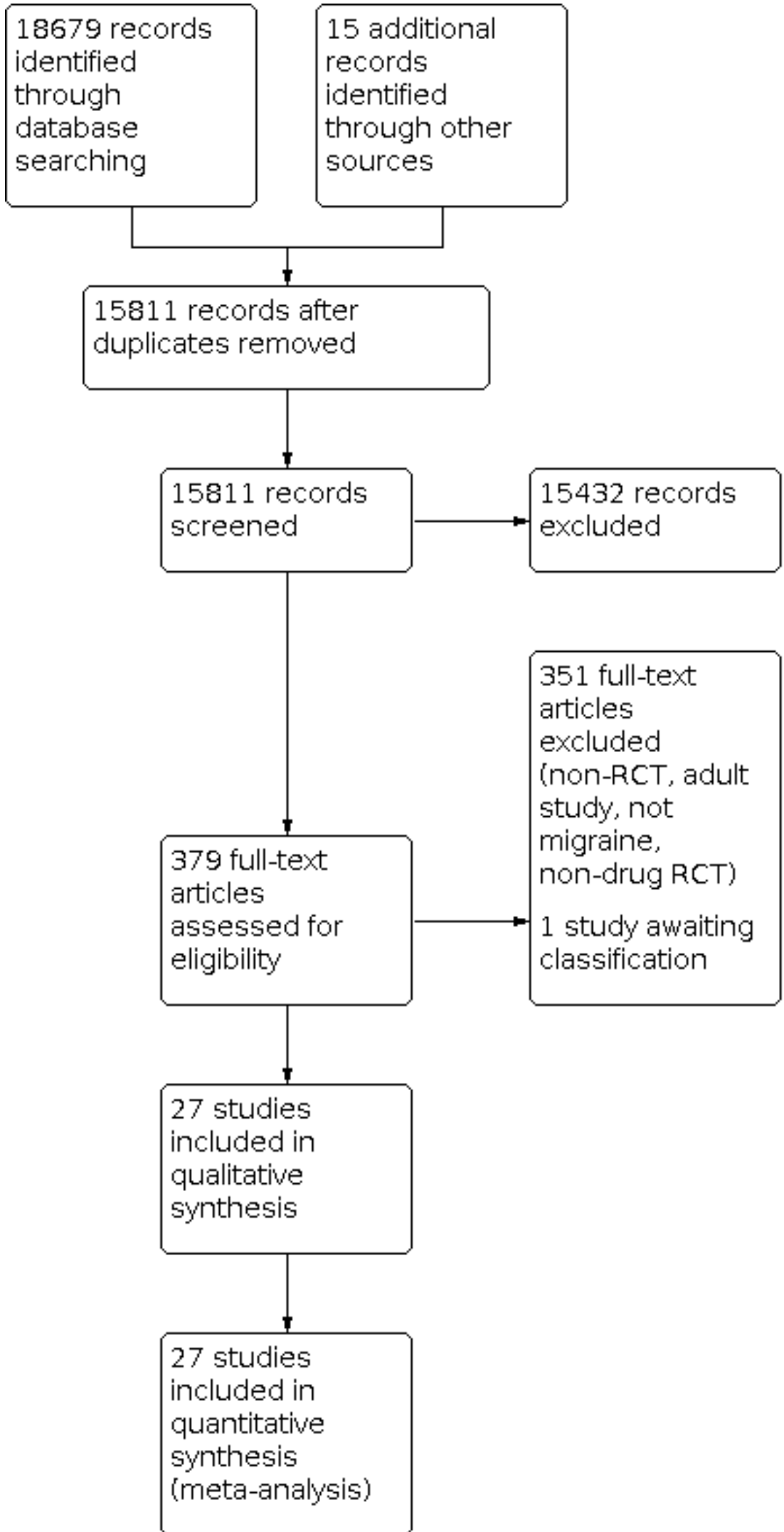




\section{Included studies}

The mean age of inclusion was 12.9 years with a range of means between 8.2 and 14.7 years. The minimum age of inclusion was 4 years in one study (Hämäläinen 1997a), and the maximum age for inclusion was 18 years in two studies (Evers 2006; Hämäläinen 1997b). Three studies included only children under 12 (Hämäläinen 2002; Lewis 2002; Ueberall 1999), and one study reported data for children and adolescents separately (Ho 2012). Six studies included children and adolescents, but they did not report the data separately (Ahonen 2004; Ahonen 2006; Evers 2006; Hämäläinen 1997a; Hämäläinen 1997b; Hämäläinen 1997c). Participants in two of the studies reporting children and adolescents combined had a mean age of less than 12 years and were included in the analysis as studies of predominantly children (Hämäläinen 1997a; Hämäläinen 1997c). Participants in the remaining four studies where children and adolescents were combined had a mean age of greater than 12 years, and we considered them to be studies of predominantly adolescents for the analysis. Finally, 17 studies included only adolescents over the age of 12 years (Callenbach 2007; Derosier 2012; Fujita 2014; Lewis 2007; Linder 2008; NCT01211145; Rothner 1997; Rothner 1999a; Rothner 1999b; Rothner 1999c; Rothner 2006; Visser 2004a; Winner 1997; Winner 2000; Winner 2002; Winner 2006; Winner 2007). The mean number of participants randomized was 359 with a range of 13 to 888 . We summarize the characteristics of included studies in Table 1, and we summarize the individual studies in Table 2. We provide more details, including a risk of bias assessment, in Characteristics of included studies.

\section{Excluded studies}

We excluded two studies, one that compared intravenous prochlorperazine versus ketorolac in children and adolescents presenting to the Emergency Department (ED) (Brousseau 2004) and one that compared intravenous metoclopramide to placebo in children and adolescents presenting to the ED (NCT00355394) from the analysis as our review is focused on outpatient acute drug therapy. All other excluded studies were either not controlled or were non-drug clinical trials (see Characteristics of excluded studies).

\section{Awaiting classification}

A single study was recently published and is awaiting classification (Winner 2015). It is a cross-over study of sumatriptan + naproxen sodium in adolescents (see Characteristics of studies awaiting classification).

\section{Risk of bias in included studies}

We illustrated the risk of bias in included studies in Figure 2 and Figure 3.

Figure 2. Risk of bias graph: review authors' judgements about each risk of bias item presented as percentages across all included studies.

Random sequence generation (selection bias)

Allocation concealment (selection bias)

Blinding (performance bias and detection bias): All outcomes Incomplete outcome data (attrition bias): All outcomes

Selective reporting (reporting bias)

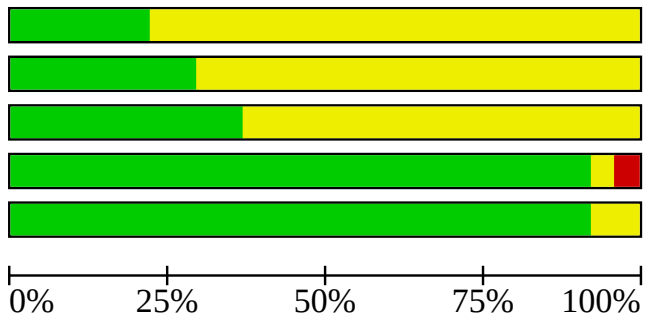

$\square$ Low risk of bias $\square$ Unclear risk of bias $\square$ High risk of bias


Figure 3. Risk of bias summary: review authors' judgements about each risk of bias item for each included study.

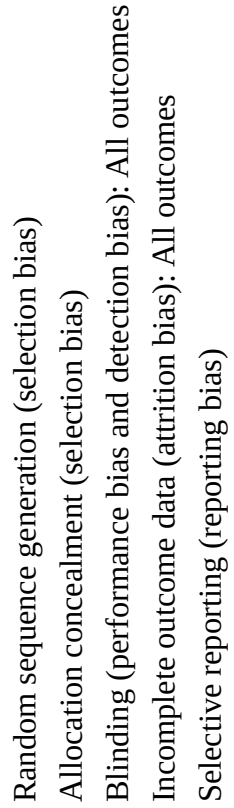

Ahonen 2004

Ahonen 2006

Callenbach 2007

Derosier 2012

Evers 2006

Fujita 2014

Hämäläinen 1997a

Hämäläinen 1997b

Hämäläinen 1997c

Hämäläinen 2002

Ho 2012

Lewis 2002

Lewis 2007

Linder 2008

NCT01211145

Rothner 1997

Rothner 1999a

Rothner 1999b

Rothner 1999c

Rothner 2006

Ueberall 1999

Visser 2004a

Winner 1997

Winner 2000

Winner 2002

Winner 2006
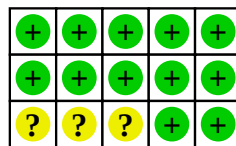
Figure 3. (Continued)

Winner 2006

Winner 2007

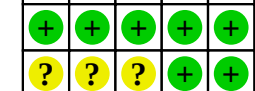

\begin{abstract}
Allocation
Investigators described all studies as randomized (low risk of selection bias (random sequence generation)), but the method of randomization was unclear in 19 studies (unclear risk of bias). Authors frequently employed generic descriptions of sequence generation such as 'randomized 1:1' or 'block randomization to two age groups'. Eight studies adequately reported allocation concealment, and we judged them to be at low risk of selection bias (allocation concealment). We judged the remaining 19 studies to be at unclear risk of bias for this domain.
\end{abstract}

\section{Blinding}

Generally, authors described all studies as double-blind, but 17 studies did not report their methods for blinding clearly (unclear risk of bias). All studies were either an oral or intranasal medication compared with placebo. Studies seldom described efforts to match for taste, color, smell, etc. We considered 10 studies to be at low risk of bias.

\section{Incomplete outcome data}

We considered incomplete reporting of outcome data to confer a high risk of bias in Winner 2002 and an unclear risk in Hämäläinen $1997 \mathrm{c}$. We considered the remaining 25 studies to be at low risk.

\section{Selective reporting}

Six studies were reported only in the sponsors' clinical trial report registry and published only in abstract form (Hämäläinen
2002; Rothner 1997; Rothner 1999a; Rothner 1999b; Rothner 1999c; Winner 1997), while one study was reported only in the sponsor's clinical trial report registry (NCT01211145). All included studies reported the pain-free primary efficacy outcome. The reports available through the sponsors' clinical trial registries were comprehensive in reporting all planned outcome measures and greatly enhanced the reported data that was published in abstract form. Also, there were no discrepancies between published abstracts and the reports released through the sponsor's clinical trial registry. Derosier 2012 was the only study that did not report the headache relief secondary outcome, and Lewis 2002 did not report adverse event data; we judged these two studies to be at unclear risk of bias for this domain. We judged the remaining 25 studies to be at low risk of bias.

\section{Other potential sources of bias}

We assessed publication bias based on the pain-free outcome for all triptans versus placebo in adolescents. On visual inspection, the funnel plot showed some asymmetry (Figure 4), suggesting the possibility of publication or other sources of bias and small-study effects. We used Egger's test to explore small-study effects, which were not significant $(P=0.139)$. The inclusion of published and unpublished data from the clinical trial registries would suggest a reduced risk of publication bias, as many of these studies were negative. 
Figure 4. Funnel plot of comparison: 7 Triptans vs placebo in Adolescents, outcome: 7.1 Pain-free.

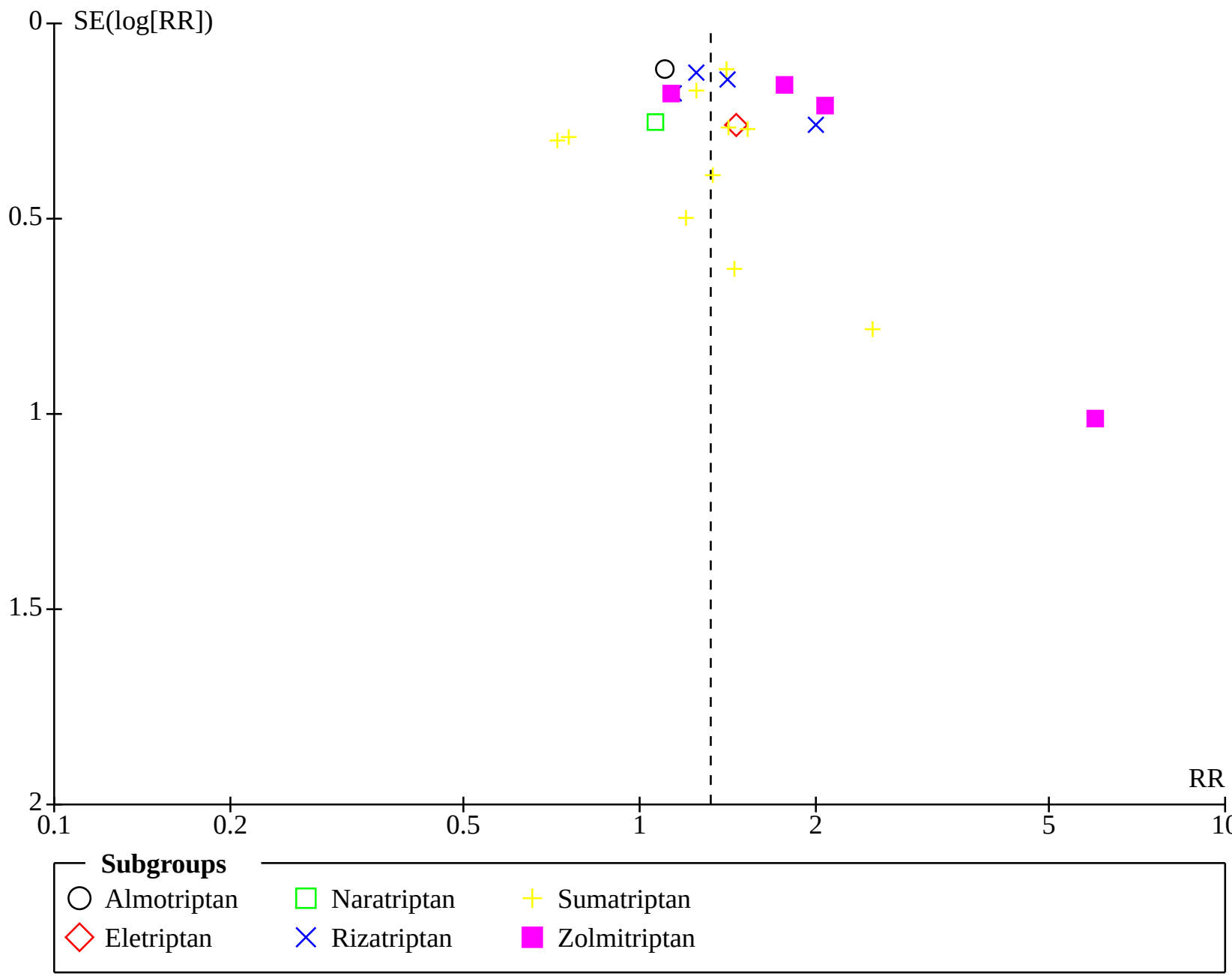

\section{Effects of interventions}

See: Summary of findings 1 Should ibuprofen be used to treat children with migraine?; Summary of findings 2 Should triptans be used to treat children with migraine?; Summary of findings 3 Should triptans be used to treat adolescents with migraine?; Summary of findings 4 Should sumatriptan plus naproxen sodium be used to treat adolescents with migraine?

We describe the measures of effect for each of the interventions below. In addition, we present 'Summary of findings' tables for all comparisons for which there was more than one study.

\section{Paracetamol versus placebo in children}

In the one three-way cross-over study that evaluated paracetamol (Hämäläinen 1997a), the participant age ranged from 4 to 15.8 years $(\mathrm{N}=88)$, but investigators did not report results for children and adolescents separately. However, the mean age of inclusion was 10.7 years, so we deemed the study to be predominantly in children. Paracetamol was not superior to placebo for the pain-free outcome ( $\mathrm{RR} 1.40,95 \% \mathrm{Cl} 0.75$ to 2.58 ). There was no statistically significant difference in headache relief (defined as a reduction in pain by two grades on a five point scale), rescue medication, headache recurrence, or adverse events. The study did not report the presence of nausea or vomiting.

\section{Ibuprofen versus placebo in children}

Ibuprofen was superior to placebo in the pooled analysis of two studies (Figure 5) - Hämäläinen 1997a was a three-way crossover study with paracetamol, with a mean participant age of 10.7 years $(\mathrm{N}=88)$, and Lewis 2002 was a parallel group study that included only 6 to 12 year-olds with a mean age of 9 years $(N=$ 84). For the pain-free primary outcome, the RR was $1.87(95 \% \mathrm{Cl}$ 1.15 to 3.04; Analysis 1.1) with a NNTB of 4. Ibuprofen was also superior to placebo for headache relief (Analysis 1.3) but not for rescue medication (Analysis 1.4) or headache recurrence (Analysis 1.5). There was no difference in the proportion of adverse events between groups (Analysis 1.2). Lewis 2002 did not report adverse events, and Hämäläinen 1997a did not report on the presence of nausea and vomiting. 
Figure 5. Forest plot of comparison: 2 lbuprofen vs placebo in Children, outcome: 2.1 Pain-free.

\begin{tabular}{|c|c|c|c|c|c|c|c|c|}
\hline \multirow[b]{2}{*}{ Study or Subgroup } & \multicolumn{2}{|c|}{ Ibuprofen } & \multicolumn{2}{|c|}{ Placebo } & \multirow[b]{2}{*}{ Weight } & \multirow{2}{*}{$\begin{array}{c}\text { Risk Ratio } \\
\text { M-H, Random, 95\% CI }\end{array}$} & \multirow{2}{*}{\multicolumn{2}{|c|}{$\begin{array}{c}\text { Risk Ratio } \\
\text { M-H, Random, 95\% CI }\end{array}$}} \\
\hline & Events & Total & Events & Total & & & & \\
\hline Hämäläinen 1997a & 12 & 20 & 6 & 21 & $40.1 \%$ & $2.10[0.98,4.51]$ & & \\
\hline Lewis 2002 & 20 & 45 & 10 & 39 & $59.9 \%$ & $1.73[0.93,3.24]$ & & \\
\hline Total (95\% CI) & & 65 & & 60 & $100.0 \%$ & $1.87[1.15,3.04]$ & & \\
\hline Total events: & 32 & & 16 & & & & & \\
\hline \multicolumn{7}{|c|}{ Heterogeneity: $\mathrm{Tau}^{2}=0.00 ; \mathrm{Chi}^{2}=0.15, \mathrm{df}=1(\mathrm{P}=0.70) ; \mathrm{I}^{2}=0 \%$} & $\begin{array}{lll}0.1 & 0.2 & 0.5\end{array}$ & $\begin{array}{lll}2 & 5 & 10\end{array}$ \\
\hline
\end{tabular}

The quality of evidence for the pain-free outcome was low, downgraded by two levels due to very serious imprecision (Summary of findings 1 ).

\section{Ibuprofen versus placebo in adolescents}

One small three-way cross-over study examined ibuprofen, zolmitriptan, and placebo (Evers 2006). While it included both children and adolescents, the mean participant age was 13.9 years $(N=29)$, so we considered the study to be predominantly in adolescents. Headache relief at two hours was the primary outcome measure reported, but investigators also reported pain freedom at two hours. The pain-free outcome was not statistically significant (RR $7.00,95 \% \mathrm{Cl} 0.99$ to 49.69 ), but ibuprofen was statistically superior to placebo for headache relief (RR 2.50, 95\% $\mathrm{Cl} 1.02$ to 6.10). There were no significant differences in other secondary outcome measures, including use of rescue medication, headache recurrence, presence of nausea, or presence of vomiting. There was no significant difference in adverse events observed.

\section{Triptans versus placebo in children}

Three studies examined two triptan medications in children under 12 years of age: rizatriptan ( $\mathrm{Ho} 2012, \mathrm{~N}=200$ ) and sumatriptan (Hämäläinen 2002, $N=59$; Ueberall 1999, $N=14$ ). Triptans as a class of medication were superior to placebo in children for the primary outcome measure of pain freedom (RR 1.67, 95\% $\mathrm{Cl} 1.06$ to 2.62; Analysis 2.1) with a NNTB of 13. There were no statistically significant differences in the effect size between rizatriptan and sumatriptan subgroups. Overall, we did not observe any statistically significant difference in the secondary outcomes of headache relief (Analysis 2.3), rescue medication (Analysis 2.4), headache recurrence (Analysis 2.5), presence of nausea (Analysis 2.6), or presence of vomiting (Analysis 2.7). There was no statistically significant difference in the proportion of adverse events observed in the triptan versus placebo groups (Analysis 2.2).

The quality of evidence for the pain-free outcome was moderate, downgraded by one level due to serious imprecision (Summary of findings 2).

\section{Triptans versus placebo in adolescents}

Triptans as a class of medications were superior to placebo in adolescents for the acute treatment of migraine (Figure 6). Overall the pain-free RR was 1.32 (95\% Cl 1.19 to 1.47 ; Analysis 3.1) with a NNTB of 6 and low $\left(I^{2}=26 \%\right)$, non-significant heterogeneity $(P=$ 0.13 ) between studies. Triptans for which there were two or more studies were statistically superior to placebo as a subgroup (Figure 6), but subgroup differences in effect size were not statistically significant. The individual triptans included were almotriptan (Linder 2008, N = 714), eletriptan (Winner 2007, N = 274), naratriptan (Rothner 1997, $\mathrm{N}=300$ ), rizatriptan (Ahonen 2006, $\mathrm{N}=96$; Winner 2002, $N=296$; Ho 2012, $N=570$; Visser 2004a, $N=476$ ), sumatriptan (Ahonen 2004, N = 83; Callenbach 2007, N = 46; Fujita 2014, N = 144; Hämäläinen 1997b, $N=23$; Rothner 1999a, N = 273; Rothner 1999b, N = 92; Rothner 1999c, N = 102; Winner 1997, N = 298; Winner 2000, $\mathrm{N}=507$; Winner 2006, $\mathrm{N}=731$ ), and zolmitriptan (Evers 2006, $\mathrm{N}=29$; Lewis 2007, $\mathrm{N}=171$; NCT01211145, $\mathrm{N}=$ 584; Rothner 2006, $\mathrm{N}=696$ ). There was, however, an increased risk of minor (nonserious) adverse events in the triptan group when compared with placebo, with an RD of $0.13(95 \% \mathrm{Cl} 0.08$ to 0.18 ; Analysis 3.2) and NNTH of 8 . The secondary efficacy outcomes that favoured triptans were headache relief (RR 1.14, 95\% Cl 1.04 to 1.24; Analysis 3.3), a reduction in the use of rescue medication (RR $0.79,95 \% \mathrm{Cl} 0.72$ to 0.87 ; Analysis 3.4), and reduced risk of headache recurrence (RR $0.79,95 \% \mathrm{Cl} 0.68$ to 0.93 ; Analysis 3.5 ). There were no statistically significant differences in the presence of nausea (Analysis 3.6) or vomiting (Analysis 3.7). 
Figure 6. Forest plot of comparison: 7 Triptans vs placebo in Adolescents, outcome: 7.1 Pain-free.

\begin{tabular}{|c|c|c|c|c|c|c|c|}
\hline & \multicolumn{2}{|c|}{ Triptan } & \multicolumn{2}{|c|}{ Placebo } & \multicolumn{2}{|r|}{ Risk Ratio } & Risk Ratio \\
\hline Study or Subgroup & Events & Total & Events & Total & Weight & M-H, Random, 95\% CI & M-H, Random, 95\% CI \\
\hline
\end{tabular}

\subsubsection{Almotriptan}

Linder 2008

Subtotal (95\% CI)

Total events:

$212 \quad 544$

544

60

170

170

$10.6 \%$

212

60

Heterogeneity: Not applicable

Test for overall effect: $\mathrm{Z}=0.85(\mathrm{P}=0.40)$

\subsubsection{Eletriptan}

Winner 2007

Subtotal (95\% CI)

31

$$
141
$$

20

133

$3.6 \%$

Total events:

31

20

Heterogeneity: Not applicable

Test for overall effect: $\mathrm{Z}=1.46(\mathrm{P}=0.14)$

\subsubsection{Naratriptan}

Rothner 1997

Subtotal (95\% CI)

$52 \quad 226$
226

Total events:

52

226

Heterogeneity: Not applicable

Test for overall effect: $\mathrm{Z}=0.25(\mathrm{P}=0.81)$

\subsubsection{Rizatriptan}

Ahonen 2006

Winner 2002

Ho 2012

Visser 2004a

Subtotal (95\% CI)

Total events:

Heterogeneity: $\mathrm{Tau}^{2}=0.01 ; \mathrm{Chi}^{2}=3.61, \mathrm{df}=3(\mathrm{P}=0.31) ; \mathrm{I}^{2}=17 \%$

Test for overall effect: $\mathrm{Z}=3.28(\mathrm{P}=0.001)$

\subsubsection{Sumatriptan}

Hämäläinen 1997b

Rothner 1999b

Rothner 1999c

Callenbach 2007

Rothner 1999a

Fujita 2014

Ahonen 2004

Winner 1997

Winner 2000

Winner 2006

Subtotal (95\% CI)

Total events:

\section{4}

$48 \quad 149$

$87 \quad 284$

$91 \quad 233$

\section{7}

40

62

96
142

$3.7 \%$

$6.4 \%$

$8.5 \%$

286

$9.8 \%$

$28.4 \%$

$$
194
$$

764

$3.8 \%$

$3.8 \%$

$1.06[0.65,1.75]$

$1.06[0.65,1.75]$

$1.46[0.88,2.43]$

$1.46[0.88,2.43]$

$1.10[0.88,1.39]$

1.10 [0.88, 1.39]

$2.00[1.20,3.33]$

1.14 [0.81, 1.62]

1.41 [1.07, 1.87]

$1.25[0.98,1.60]$

1.34 [1.13, 1.60]

$2.50[0.54,11.60]$

1.45 [0.42, 4.98]

1.20 [0.45, 3.18]

$1.33[0.62,2.86]$

$0.72[0.40,1.30]$

$0.76[0.43,1.34]$

$1.53[0.90,2.60]$

1.42 [0.84, 2.39]

$1.25[0.89,1.75]$

1.41 [1.12, 1.77]

1.27 [1.10, 1.48]

$6.00[0.83,43.59]$

2.07 [1.37, 3.13]

$1.13[0.80,1.61]$

$1.77[1.30,2.41]$

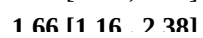

\subsubsection{Zolmitriptan}

Lewis 2007

Rothner 2006

NCT01211145

Suhtntal (95\% r.I)

$\begin{array}{rrrrr}6 & 14 & 1 & 14 & 0.3 \% \\ 58 & 148 & 24 & 127 & 5.1 \% \\ 108 & 483 & 32 & 162 & 6.4 \% \\ 86 & 288 & 50 & 296 & 7.6 \% \\ & \mathbf{9 3 3} & & \mathbf{5 9 9} & \mathbf{1 9 ~ 3 \%}\end{array}$

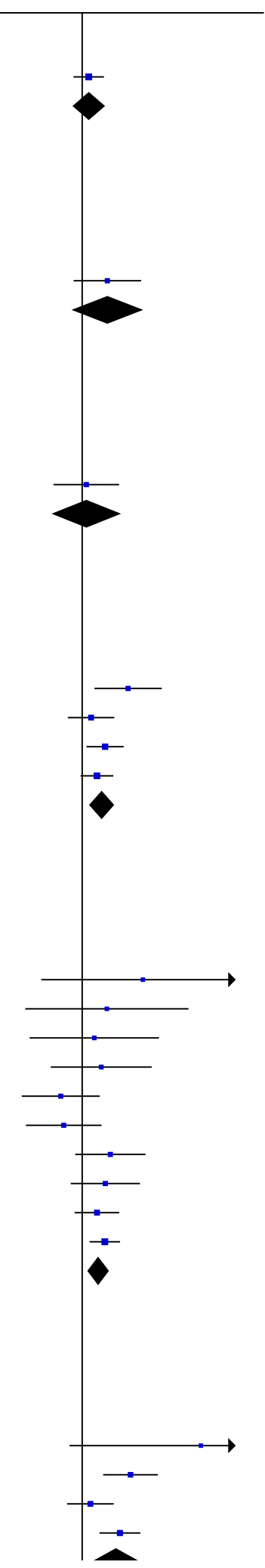


Figure 6. (Continued)
NCT01211145
Subtotal (95\% CI)
Total events:
86
288
933
50
296
$7.6 \%$
258
599
$19.3 \%$
107
Heterogeneity: $\mathrm{Tau}^{2}=0.07 ; \mathrm{Chi}^{2}=7.34, \mathrm{df}=3(\mathrm{P}=0.06) ; \mathrm{I}^{2}=59 \%$
Test for overall effect: $\mathrm{Z}=2.79(\mathrm{P}=0.005)$

$1.77[1.30,2.41]$
$\mathbf{1 . 6 6}[\mathbf{1 . 1 6}, \mathbf{2 . 3 8}]$

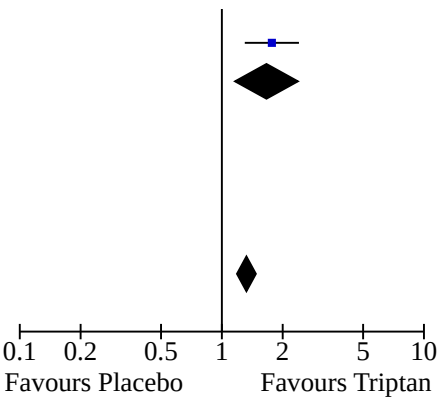

The quality of evidence for the pain-free outcome was moderate, downgraded by one level due to serious inconsistency (Summary of findings 3 ).

\section{Sumatriptan plus naproxen sodium versus placebo in adolescents}

We included one study of sumatriptan plus naproxen sodium versus placebo. The study included adolescents with a mean age of 14.7 years and randomized a total of 683 participants. The doses of sumatriptan + naproxen sodium, respectively, were $10 \mathrm{mg}+60$ $\mathrm{mg}(\mathrm{N}=96), 30 \mathrm{mg}+180 \mathrm{mg}(\mathrm{N}=97)$, and $85 \mathrm{mg}+500 \mathrm{mg}$ $(\mathrm{N}=152)$. The primary outcome reported was pain freedom at two hours, with data adjusted for age and baseline severity. The adjusted pain-free rates at two hours were higher with sumatriptan + naproxen sodium $10 \mathrm{mg}+60 \mathrm{mg}(29 \%$; adjusted $\mathrm{P}=0.003)$, $30 \mathrm{mg}+180 \mathrm{mg}(27 \%$; adjusted $\mathrm{P}=0.003)$, and $85 \mathrm{mg}+500$ $\mathrm{mg}$ (24\%; adjusted $\mathrm{P}=0.003$ ) versus placebo $(10 \%)$. Post hoc analyses showed no differences among the 3 doses or an age-bytreatment interaction. Calculating the RR for pain relief at 2 hours, sumatriptan + naproxen sodium was superior to placebo with an RR of 3.25 (95\% Cl 1.78 to 5.94) and NNTB of 6 . The use of rescue medication was also significantly reduced with the combination medication when compared with placebo (RR $0.46,95 \% \mathrm{Cl} 0.32$ to $0.64)$, but investigators did not report headache relief. There was no statistically significant increase in adverse events and no difference in the presence of nausea. Headache recurrence and presence of vomiting were also not reported.

The quality of evidence for the pain-free outcome was moderate, downgraded by one level due to the width of the confidence interval of the effect size (Summary of findings 4).

\section{Dihydroergotamine (DHE) versus placebo in children}

One small cross-over study of dihydroergotamine versus placebo included children and adolescents aged 5 to 15 years (Hämäläinen 1997 c, $N=13$ ). With a mean participant age of 10.3 years, we considered the study to be predominantly in children. DHE demonstrated no significant difference in the pain-free outcome or any of the secondary outcomes, including headache relief or the use of rescue medications. There was no statistically significant increase in the proportion of adverse events between DHE and placebo. Authors did not report headache recurrence, presence of nausea, or the presence of vomiting.

\section{Subgroup analysis for other sources of heterogeneity}

We assessed potentially important sources of clinical heterogeneity using the pain-free outcome of triptan studies in adolescents. Tests for subgroup differences showed that effect size estimates for intranasal studies of sumatriptan and zolmitriptan were significantly higher than oral triptan studies of almotriptan, eletriptan, naratriptan, rizatriptan, sumatriptan, and zolmitriptan $\left(P=0.02,1^{2}=81.5 \%\right.$, Analysis 4.1$)$. We observed a statistically significant difference in the comparison of oral versus intranasal zolmitriptan studies, where intranasal delivery was associated with a significantly higher effect size for the pain-free outcome $(P=0.04)=, I^{2}=77.1 \%$; Analysis 4.3$)$. However, the difference was not statistically significant when comparing oral versus intranasal sumatriptan studies (Analysis 4.2). The permitted concomitant use of migraine preventive medications in the triptan trials among adolescents was not associated with any significant difference in the effect size (Analysis 4.4). We did not observe any statistically significant differences in the overall effect size estimates between the triptan versus placebo studies that included only children, those where children and adolescents were mixed and not reported separately, and those studies that examined adolescents exclusively $\left(P=0.42,1^{2}=0 \%\right.$; Analysis 5.1).

\section{Sensitivity analysis of other study characteristics}

The overall heterogeneity was low for the triptan versus placebo studies in adolescents for the pain-free outcome $\left(\mathrm{Tau}^{2}=0.01\right.$; $\mathrm{Chi}^{2}=27.15$, degrees of freedom $\left.(\mathrm{df})=20(\mathrm{P}=0.13) ; \mathrm{I}^{2}=26 \%\right)$. We performed a sensitivity analysis to explore the effects of sponsorship; risk of bias in allocation concealment; study design (cross-over versus parallel group); type of study report (journal article versus clinical trial registry and abstract); and small sample size $(<50)$. The cross-over study design was associated with significantly higher effect size estimates for the pain-free outcome $\left(P=0.004,1^{2}=88.2 \%\right.$; Analysis 6.1). The effect estimate for the triptan versus placebo studies in adolescents was similar in direction, magnitude, and significance (i.e. RR 1.25, 95\% Cl 1.12 to 1.39 ) when we removed studies of cross-over design. Similarly studies with a sample size of less than 50 had a significantly higher estimates of treatment effect $(P=0.03,12=79.4 \%$; Analysis 6.5$)$. The overall effect estimate without studies having small sample sizes was similar to the reported effect estimate (RR $1.31,95 \% \mathrm{Cl} 1.18$ to 1.46). There were no significant subgroup difference for allocation concealment (Analysis 6.2), source of funding (Analysis 6.3), or type of study report (Analysis 6.4). 


\section{DISCUSSION}

\section{Summary of main results}

In total, we identified 27 moderate quality studies for inclusion. Most were at a low or unclear risk of bias and of varying size (a range of 13 to 888 participants in total). The mean age of inclusion was 12.9 years with a range of means between 8.2 and 14.7 years.

\section{Paracetamol}

There is insufficient evidence in favor of paracetamol for the acute treatment of migraine in children or adolescents. We only identified one small cross-over study, predominantly in children, where oral paracetamol was not superior to placebo or ibuprofen.

\section{Ibuprofen}

Ibuprofen was more effective than placebo in producing pain freedom in two small studies involving children. In one small crossover study in adolescents, ibuprofen was not superior to placebo for pain freedom, but it was for headache relief (Evers 2006). While ibuprofen as a non-steroidal anti-inflammatory drug (NSAID) may have some advantage in the treatment of a migraine attack, considering the presence of neurogenic inflammation (Levy 2008), it was not superior to zolmitriptan or paracetamol in two three-way cross-over studies (Evers 2006; Hämäläinen 1997a). Ibuprofen was not associated with an increase in adverse events overall.

\section{Triptans}

Triptans as a class of medication were more effective than placebo in producing pain freedom in 3 studies involving children and 21 studies involving adolescents. We did not observe any significant differences in the effect sizes between the subgroups of individual triptans, including almotriptan, eletriptan, naratriptan, rizatriptan, sumatriptan, or zolmitriptan. While there was some evidence to suggest that intranasal preparations of sumatriptan and zolmitriptan produce higher effect sizes than oral preparations of all the triptans listed above, the evidence was inconsistent. Evidence for the efficacy of the triptans was variable, as measured through the secondary outcomes of headache relief, use of rescue medication, headache recurrence, presence of nausea, and presence of vomiting, but in general it favored the triptans. The efficacy, however, is counterbalanced with an increased risk of minor (non-serious) adverse events overall. However, there were no serious adverse events reported. Commonly reported adverse events included fatigue, dizziness, asthenia, dry mouth, and nausea or vomiting with oral preparations, and taste disturbance, nasal symptoms, and nausea with intranasal preparations. The combination of sumatriptan with naproxen sodium was also more effective than placebo in producing pain freedom in one adolescent study. We did not observe any significant differences in the effect sizes between studies that included children versus adolescents. The only significant study characteristic that was associated with a higher effect size was the use of a cross-over design versus parallel group design.

\section{Dihydroergotamine}

There is insufficient evidence for oral dihydroergotamine in the treatment of migraine in children or adolescents. We only identified one small cross-over study, which found that oral dihydroergotamine was not superior to placebo.

\section{Overall completeness and applicability of evidence}

Of the 27 randomized controlled trials we identified on migraine symptom relieving medications used in the outpatient setting for children and adolescents, 24 belonged to the triptan class, including almotriptan, eletriptan, naratriptan, rizatriptan, sumatriptan, and zolmitriptan. Pharmaceutical companies sponsored most of the triptan studies $(\mathrm{N}=19)$. We only identified three studies of the most frequently used pain medications (paracetamol and ibuprofen) and none examining other nonsteroidal anti-inflammatory drugs (NSAIDs) or early treatment (Goadsby 2008; Suthisisang 2010). We only identified one study on a combination medication (sumatriptan plus naproxen sodium).

\section{Quality of the evidence}

We judged the quality of evidence for the effect of triptans on pain relief to be moderate, having downgraded it due to serious inconsistency in adolescents and imprecision in children (small sample size, few events, and wide confidence intervals. For ibuprofen, we downgraded the quality of the evidence by two levels to low due to very serious imprecision (small sample size, few events, and wide confidence intervals). It is likely that future research will help to tighten the confidence intervals around the effect size of the above medications. More evidence is needed to assess the effect of paracetamol in children and adolescents. Although we identified heterogeneity between the results in the triptan studies, we believe that further research is unlikely to change the direction of the effect.

\section{Potential biases in the review process}

The reviewers searched the indexed and gray literature extensively to identify all published and unpublished studies of medications used in the treatment of migraine in children and adolescents. Pharmaceutical company clinical trial registries were available for sumatriptan, sumatriptan + naproxen sodium, rizatriptan, and zolmitriptan studies, and we identified some negative trials in these sources. The absence of trial registries for the other medications may bias the identification of other negative trials. The funnel plot examination suggested some potential for publication bias, but the Egger statistical tests for bias were not significant.

\section{Agreements and disagreements with other studies or reviews}

A number of similar systematic reviews have been published. The review by Major 2003 of triptan studies in children and adolescents aged 6 to 18 years concluded that intranasal sumatriptan was effective, while other oral triptans were not. The American Academy of Neurology Quality Standards Subcommittee and the Practice Committee of the Child Neurology Society have published a practice parameter on the pharmacological treatment of migraine (Lewis 2004). Our conclusions are similar with regard to the evidence for efficacy of ibuprofen in children but differ with regard to the efficacy of paracetamol. The practice parameter also concluded that sumatriptan nasal spray was effective for the acute treatment of migraine in adolescents. Damen 2005 evaluated all randomized controlled trials for the acute treatment of migraine in children and adolescents less than 18 years of age but identified a smaller number of trials (10 studies). The authors performed a meta-analysis, and concluded there was evidence for the use of ibuprofen, paracetamol, and intranasal sumatriptan. Silver 2008 also included all medications for the acute treatment of migraine 
in their search, but identified only 11 studies in children and adolescents under 18 years of age. The authors concluded that there was evidence only for the use of ibuprofen and sumatriptan and did not differentiate between oral and intranasal sumatriptan preparations. A meta-analysis and qualitative review of ibuprofen and paracetamol in adults, adolescents, and children concluded that ibuprofen was at least as efficacious as paracetamol (Pierce 2010). Eiland 2010 recommended the triptan class as an acute treatment option for children and adolescents with migraines, also concluding that there was evidence to recommend sumatriptan and zolmitriptan nasal sprays as well as rizatriptan or almotriptan tablets over the other triptans. Vollono 2011 examined 11 studies and concluded that triptans are an important option in the symptomatic treatment of childhood and adolescent migraine. Individually, they found that zolmitriptan and rizatriptan were superior to placebo in most studies, and almotriptan was well tolerated. Toldo 2012 recommended paracetamol and ibuprofen as first line treatments for migraine in children and adolescents. The triptans were deemed safe, and the authors concluded that sumatriptan nasal spray was more effective than placebo and that zolmitriptan nasal spray and rizatriptan tablets were likely effective. Wöber-Bingöl 2013 examined 14 studies on triptans in adolescents and 6 studies in children and concluded that evidence for the acute pharmacological treatment of migraine in children was poor, but evidence for adolescents was better, albeit still limited. The authors outlined that sumatriptan nasal spray and zolmitriptan nasal spray were approved for adolescents in Europe; while in the United States almotriptan can be used for adolescents and rizatriptan is approved for patients aged 6 to 17 years. The combination of sumatriptan and naproxen sodium in adolescents has also since been approved for use in adolescents in the United States. Bonfert 2013 included 33 studies examining acute and preventive treatment for migraine and tension-type headaches. The reviewers did not conduct a meta-analysis but reviewed the individual studies, concluding that ibuprofen and paracetamol should be considered first and second line therapies for the acute treatment of migraine in children and adolescents, with almotriptan and rizatriptan as suitable third-line agents.

Finally, a recent review identified only seven studies in adolescents aged 12 to 17 years and concluded that enrichment designs significantly reduced placebo response (Sun 2013). Our review includes a higher number of studies ( $N=27$ ), including negative studies published only in pharmaceutical-industry sponsored trial registries. We draw similar conclusions with regard to the benefit and safety of ibuprofen in treating children and adolescents with migraine. As with previous reviews, the low cost, broad availability, and safety may make ibuprofen a preferred first choice. We differ however in our conclusion that there is insufficient evidence to recommend paracetamol. In general our conclusions are similar with regard to the triptans as a class of medication being effective in the treatment of children and adolescents with migraine. We differ in that we found insufficient evidence to recommend one triptan over the others in our meta-analysis and sub-group analyses. While rizatriptan, sumatriptan, and zolmitriptan were statistically superior to placebo as subgroups, the overall test for subgroup heterogeneity was not significant. In our meta-analysis, we combined the studies of triptan medications irrespective of route of delivery and dosage.

\section{AUTHORS' CONCLUSIONS}

\section{Implications for practice}

We found low quality evidence from two small studies that ibuprofen appears to improve pain relief in children with migraine. We have only limited information on adverse events in the trials included in this review. There is insufficient evidence in favor of paracetamol. We did not identify evidence regarding early treatment, the use of other NSAIDs, or the combination of these analgesics with other medications (e.g. metoclopramide, caffeine) in children or adolescents.

For children and adolescents with migraine, triptans appear to be effective in the acute treatment of migraine. Sumatriptan plus naproxen sodium is effective in adolescents, but we did not find any studies in children. Triptans are generally safe but carry an increased risk of minor (non-serious) adverse events.

For clinicians, the choice of triptan medication may be guided by factors such as patient preference, route of delivery, or palatability. A parent who responds well to one of the medications may be more likely to request that medication for their child. More than half of the triptan studies in children and adolescents were of sumatriptan, and this medication serves as the reference drug in this class. The choice of triptan may also be based on local availability, drug cost reimbursement, and regulatory approval. We found inconsistent evidence in our subgroup analysis of the intranasal versus oral triptan preparations, but patients may prefer one route over the other (e.g. intranasal if significant vomiting or oral if patient has chronic rhinitis).

For policymakers and funders, the triptan class of medications, as well as sumatriptan in combination with naproxen sodium, are suitable options for children and adolescents with migraine. One or more of these medications should be made available in situations where ibuprofen has failed to provide pain freedom or headache relief.

\section{Implications for research}

\section{General}

Future studies should separate the childhood and adolescent age groups to enable separate meta-analyses of these groups. More studies of simple analgesics commonly used in the treatment of migraine like paracetamol and ibuprofen, other NSAIDs, or head to head comparisons are warranted.

\section{Design}

Studies employing a cross-over design were associated with significantly higher effect size estimates. Similar findings have been reported previously (Lathyris 2007). This may have been due to inadequate blinding in cross-over studies or higher effect estimates due to the smaller sample size. Guidelines for controlled trials of drugs in migraine advocate the use of either cross-over or parallel design (Tfelt-Hansen 2012).

\section{Measurement (endpoints)}

Pain freedom as an outcome measure demonstrated low heterogeneity between studies and may be most suitable as a primary outcome measure. Data on other outcome measures (e.g. nausea, headache relief, etc.) should also be collected, as described 
in the guidelines for controlled trials of drugs in migraine (TfeltHansen 2012).

\section{ACKNOWLEDGEMENTS}

Dr. Lawrence Richer wishes to thank Dr. Brian Rowe for mentoring his Master of Science in Clinical Epidemiology training and thesis preparation.
Cochrane Review Group funding acknowledgement: The National Institute for Health Research (NIHR) is the largest single funder of the Cochrane PaPaS Group. Disclaimer: The views and opinions expressed therein are those of the authors and do not necessarily reflect those of the NIHR, National Health Service (NHS) or the Department of Health. 


\section{RE F E R E N C E S}

\section{References to studies included in this review}

Ahonen 2004 \{published data only\}

Ahonen K, Hämäläinen ML, Rantala H, Hoppu K. Nasal sumatriptan is effective in treatment of migraine attacks in children: a randomized trial. Neurology 2004;62(6):883-7. [DOI: 10.1212/01.WNL.0000115105.05966.A7]

\section{Ahonen 2006 \{published data only\}}

Ahonen K, Hämäläinen ML, Eerola M, Hoppu K. A randomized trial of rizatriptan in migraine attacks in children. Neurology 2006;67(7):1135-40. [DOI: 10.1212/01.wnl.0000238179.79888.44]

\section{Callenbach 2007 \{published and unpublished data\}SUM30042}

* Callenbach PM, Pels LP, Mulder PG, Linssen WH, Gooskens RH, Van der Zwan JL, et al. Sumatriptan nasal spray in the acute treatment of migraine in adolescents and children. European Journal of Paediatric Neurology 2007;11(6):325-30. [DOI: 10.1016/j.ejpn.2007.02.010]

SUM30042. A multi-centre, randomised, double-blind, placebocontrolled, cross-over study to investigate the efficacy, safety and tolerability of sumatriptan nasal spray $(10 \mathrm{mg}$ or $20 \mathrm{mg}$ ) in the treatment of migraine in patients aged 12-17. http:// www.gsk-clinicalstudyregister.com/study/SUM30042\#rs (accessed 24 June 2015).

\section{Derosier 2012 \{published and unpublished data\}}

Derosier FJ, Lewis D, Hershey AD, Winner PK, Pearlman E, Rothner AD, et al. Randomized trial of sumatriptan and naproxen sodium combination in adolescent migraine. Pediatrics 2012;129(6):e1411-20. [DOI: 10.1542/peds.2011-2455]

\section{Evers 2006 \{published data only\}}

Evers S, Rahmann A, Kraemer C, Kurlemann G, Debus O, Husstedt IW, et al. Treatment of childhood migraine attacks with oral zolmitriptan and ibuprofen. Neurology 2006;67(3):497-9. [DOI: 10.1212/01.wnl.0000231138.18629.d5]

\section{Fujita 2014 \{published and unpublished data\}SUM111035}

* Fujita M, Sato K, Nishioka H, Sakai F. Oral sumatriptan for migraine in children and adolescents: a randomized, multicenter, placebo-controlled, parallel group study. Cephalalgia 2014;34(5):365-75. [DOI: $10.1177 / 0333102413510213]$

SUM111035. A randomized, multicenter, placebo-controlled, parallel group study to evaluate the efficacy and safety of oral sumatriptan for the acute treatment of migraine in children and adolescents. http://www.gsk-clinicalstudyregister.com/ study/111035\#ps (accessed 24 June 2015).

\section{Hämäläinen 1997a \{published data only\}}

Hämäläinen ML, Hoppu K, Valkeila E, Santavuori P. Ibuprofen or acetaminophen for the acute treatment of migraine in children: a double-blind, randomized, placebo-controlled, crossover study. Neurology 1997;48(1):103-7. [DOI: 10.1212/WNL.48.1.103]
Hämäläinen 1997b \{published data only\}

Hämäläinen ML, Hoppu K, Santavuori P. Sumatriptan for migraine attacks in children: a randomized placebo-controlled study. Do children with migraine respond to oral sumatriptan differently from adults? Neurology 1997;48(4):1100-3. [PMID: 9109909]

\section{Hämäläinen 1997c \{published data only\}}

Hämäläinen M, Hoppu K, Santavuori PR. Oral dihydroergotamine for therapy-resistant migraine attacks in children. Pediatric Neurology 1997;16(2):114-7. [DOI: 10.1016/ S0887-8994(96)00289-5]

Hämäläinen 2002 \{published and unpublished data\}SUM30009

* Hämäläinen M, Jones M, Loftus J, Saiers J. Sumatriptan nasal spray for migraine: a review of studies in patients aged 17 years and younger. International Journal of Clinical Practice 2002;56(9):704-9. [PMID: 12469987]

SUM30009. A single centre, placebo-controlled, double blind, randomised cross-over, single attack study evaluating the efficacy and tolerability of sumatriptan nasal spray $10 \mathrm{mg}$ for the acute treatment of migraine in children suffering from refractory migraine with/without aura. http://www.gskclinicalstudyregister.com/study/SUM30009\#rs (accessed 24 June 2015).

\section{Ho 2012 \{published data only\}}

Ho TW, Pearlman E, Lewis D, Hämäläinen M, Connor K, Michelson D, et al. Efficacy and tolerability of rizatriptan in pediatric migraineurs: results from a randomized, doubleblind, placebo-controlled trial using a novel adaptive enrichment design. Headache 2012;32(10):750-65. [DOI: 10.1177/0333102412451358]

\section{Lewis 2002 \{published data only\}}

Lewis DW, Kellstein D, Dahl G, Burke B, Frank LM, Toor S, et al. Children's ibuprofen suspension for the acute treatment of pediatric migraine. Headache 2002;42(8):780-6. [DOI: 10.1046/ j.1526-4610.2002.02180.x]

\section{Lewis 2007 \{published data only\}}

Lewis DW, Winner P, Hershey AD, Waslewski WW, Adolescent Migraine Steering Committee. Efficacy of zolmitriptan nasal spray in adolescent migraine. Pediatrics 2007;120(2):390-6. [DOI: 10.1542/peds.2007-0085]

\section{Linder 2008 \{published and unpublished data\}}

Linder SL, Mathew NT, Cady RK, Finlayson G, Ishkanian G, Lewis DW. Efficacy and tolerability of almotriptan in adolescents: a randomized, double-blind, placebocontrolled trial. Headache 2008;48(9):1326-36. [DOI: 10.1111/ j.1526-4610.2008.01138.x]

\section{NCT01211145 \{published and unpublished data\}NCT01211145}

NCT01211145. Zomig - treatment of acute migraine headache in adolescents (TEENZ). clinicaltrials.gov/ct2/show/NCT01211145 (accessed 24 June 2015). 
Rothner 1997 \{published and unpublished data\}S2WA3012

* Rothner A, Edwards K, Kerr L, DeBussey S, Asgharnejad M. Efficacy and safety of naratriptan tablets in adolescent migraine. Journal of Neurological Sciences 1997;150(Suppl 1):S106.

S2WA3012. A randomized, double-blind, placebo-controlled, parallel study to evaluate the efficacy, safety and tolerability of oral naratriptan in an adolescent migraine population. http://www.gsk-clinicalstudyregister.com/study/S2WA3012\#rs (accessed 24 June 2015).

Rothner 1999a \{published and unpublished data\}SUMB2003

* Rothner D, Asgharnejad M. Tolerability of sumatriptan tablets in the acute treatment of migraine in adolescent patients: a review of data from clinical trials. European Journal of Neurology 1999;6(Suppl 3):106.

SUMB2003. A double-blind, randomised, placebo-controlled study to compare the efficacy and safety of oral sumatriptan (25mg, 50mg and $100 \mathrm{mg}$ ) in the acute treatment of migraine in adolescents. http://www.gsk-clinicalstudyregister.com/study/ SUMB2003\#rs (accessed 24 June 2015).

\section{Rothner 1999b \{published and unpublished data\}S2CT37}

Rothner D, Asgharnejad M. Tolerability of sumatriptan tablets in the acute treatment of migraine in adolescent patients: a review of data from clinical trials. European Journal of Neurology 1999;6(Suppl 3):106.

\section{Rothner 1999c \{published and unpublished data\}S2CT40}

Rother D, Asgharnejad M. Tolerability of sumatriptan tablets in the acute treatment of migraine in adolescent patients: a review of data from clinical trials. European Journal of Neurology 1999;6(Suppl 3):106. [GSK ID: S2CT40]

\section{Rothner 2006 \{published data only\}}

Rothner AD, Wasiewski W, Winner P, Lewis D, Stankowski J. Zolmitriptan oral tablet in migraine treatment: high placebo responses in adolescents. Headache 2006;46(1):101-9. [DOI: 10.1111/j.1526-4610.2006.00313.x]

\section{Ueberall 1999 \{published data only\}}

Ueberall MA, Wenzel D. Intranasal sumatriptan for the acute treatment of migraine in children. Neurology 1999;52(7):1507-10. [PMID: 10227648]

\section{Visser 2004a \{published data only\}}

Visser WH, Winner P, Strohmaier K, Klipfel M, Peng Y, McCarroll K, et al. Rizatriptan $5 \mathrm{mg}$ for the acute treatment of migraine in adolescents: results from a doubleblind, single-attack study and two open-label, multipleattack studies. Headache 2004;44:891-9. [DOI: 10.1111/ j.1526-4610.2004.04171.x]

\section{Winner 1997 \{published and unpublished data\}SUMA2002} Winner P, Prensky A, Linder S, DeBussey S, Asgharnejad M. Adolescent migraine: efficacy and safety of sumatriptan tablets. Journal of the Neurological Sciences 1997;150(Suppl 1):S172. [DOI: 10.1016/S0022-510X(97)85694-8]

\section{Winner 2000 \{published and unpublished data\}SUMA3005}

Winner P, Rothner AD, Saper J, Nett R, Asgharnejad M, Laurenza A, et al. A randomized, double-blind, placebocontrolled study of sumatriptan nasal spray in the treatment of acute migraine in adolescents. Pediatrics 2000;106(5):989-97. [PMID: 11061765]

\section{Winner 2002 \{published data only\}}

Winner P, Lewis D, Visser WH, Jiang K, Ahrens S, Evans JK, et al. Rizatriptan $5 \mathrm{mg}$ for the acute treatment of migraine in adolescents: a randomized, double-blind, placebocontrolled study. Headache 2002;42(1):49-55. [DOI: 10.1046/ j.1526-4610.2002.02013.x]

\section{Winner 2006 \{published data only\}}

SUM30045. A double-blind, placebo-controlled, parallel group study to evaluate two dose levels (5mg And 20mg) of sumatriptan nasal spray in the acute treatment of a single migraine attack in adolescent migraineurs (12-17 years of age). http://www.gsk-clinicalstudyregister.com/study/SUM30045\#rs (accessed 24 June 2015).

* Winner P, Rothner AD, Wooten JD, Webster C, Ames M. Sumatriptan nasal spray in adolescent migraineurs: a randomized, double-blind, placebo-controlled, acute study. Headache 2006;46(2):212-22. [DOI: 10.1111/ j.1526-4610.2006.00339.x]

Winner P, Rothner D, Webster CJ, Ames MH, Kori SH. Randomized, double-blind, placebo- controlled study of sumatriptan nasal spray in adolescent migraineurs. Neurology 2004;62(7 Suppl 5):A182.

\section{Winner 2007 \{published data only\}}

Pitman V. Efficacy, safety and tolerability of oral eletriptan (40 $\mathrm{mg}$ ) for the treatment of migraine in adolescents (12-17 years). Headache 2000;40(5):424-5.

* Winner P, Liner SL, Lipton RB, Almas M, Parsons B, Pitman V. Eletriptan for the acute treatment of migraine in adolescents: results of a double-blind, placebo-controlled trial. Headache 2007;47(4):511-8. [DOI: 10.1111/j.1526-4610.2007.00755.x]

\section{References to studies excluded from this review}

Brousseau 2004 \{published data only\}

Brousseau DC, Duffy SJ, Anderson AC, Linakis JG. Treatment of pediatric migraines: a randomized, double-blind trial of prochlorperazine versus ketorolac. Annals of Emergency Medicine 2004;43(2):256-62. [DOI: 10.1016/ S0196-0644(03)00716-9]

\section{Cady 2011 \{published data only\}}

Cady RK, Goldstein J, Nett R, Mitchell R, Beach ME, Browning R. A double-blind placebo-controlled pilot study of sublingual feverfew and ginger (LipiGesic TM M) in the treatment of migraine. Headache 2011;51(7):1078-86. [DOI: 10.1111/ j.1526-4610.2011.01910.x] 
Gertsch 2011 \{published data only\}

Gertsch EA, Loharuka S, Wolter-Warmerdam KG, Tong S, Kedia S. Intravenous magnesium as abortive treatment for headaches in children. Annals of Neurology 2011;70(S15):S167. [DOI: 10.1002/ana.22563]

\section{NCT00355394 \{unpublished data only\}}

NCT00355394. Treatment of acute migraine headache in children. clinicaltrials.gov/show/NCT00355394 (accessed 3 February 2016).

\section{Soriani 2001 \{published data only\}}

Soriani S, Battistella PA, Naccarella C, Tozzi E, Fiumana E, Fanaro S. Nimesulide and acetaminophen for the treatment of juvenile migraine: a study for comparison of efficacy, safety, and tolerability. Headache Quarterly 2001;12:233-6.

\section{SUM40090 \{published data only\}}

SUM40090. The use of oral sumatriptan on compassionate grounds for the acute treatment of migraine in adolescent patients (ages 12 to 17). http://www.gskclinicalstudyregister.com/study/SUM40090\#rs (accessed 24 June 2015).

\section{Trautmann 2010 \{published data only\}}

Trautmann E, Kroner-Herwig B. A randomized controlled trial of Internet-based self-help training for recurrent headache in childhood and adolescence. Behaviour Research \& Therapy 2010;48(1):28-37. [DOI: 10.1016/j.brat.2009.09.004]

Winner 2011 \{published data only\}

Winner P. Sumatriptan formulated with RT technology ${ }^{\mathrm{TM}}$ as early intervention for migraine in adolescents. Journal of Pediatric Neurology 2011;9(2):169-75. [DOI: 10.3233/ JPN-2011-0471]

\section{References to studies awaiting assessment}

Winner 2015 \{published and unpublished data\}

NCT01016678. Treximet Early Intervention Adolescent Migraine (TEAM). clinicaltrials.gov/ct2/show/NCT01016678 (accessed 24 June 2015)

* Winner P, Linder S, Hershey AD. Consistency of response to sumatriptan/naproxen sodium in a randomized placebocontrolled, cross-over study for the acute treatment of migraine in adolescents. Headache 2015;55:519-28. [DOI: 10.1111/ head.12555]

\section{Additional references}

\section{Bille 1997}

Bille B. A 40-year follow-up of school children with migraine. Cephalalgia 1997;17(4):488-91; discussion 487. [DOI: 10.1046/ j.1468-2982.1997.1704488.x]

\section{Bonfert 2013}

Bonfert M, Straube A, Schroeder AS, Reilich P, Ebinger F, Heinen F. Primary headache in children and adolescents: update on pharmacotherapy of migraine and tension-type headache. Neuropediatrics 2013;44(1):3-19. [DOI: 10.1055/ s-0032-1330856]

\section{Curtin 2002}

Curtin F, Elbourne D, Altman DG. Meta-analysis combining parallel and cross-over clinical trials. II: binary outcomes. Statistics in Medicine 2002;21(15):2145-59. [DOI: 10.1002/ sim.1206]

\section{Damen 2005}

Damen L, Bruijn JK, Verhagen AP, Berger MY, Passchier J, Koes BW. Symptomatic treatment of migraine in children: a systematic review of medication trials. Pediatrics 2005;116(2):e295-302. [DOI: 10.1542/peds.2004-2742]

\section{Davies 2000}

Davies GM, Santanello N, Lipton R. Determinants of patient satisfaction with migraine therapy. Cephalalgia 2000;20(6):554-60. [DOI: 10.1046/j.1468-2982.2000.00082.x]

\section{Egger 1997}

Egger M, Davey Smith G, Schneider M, Minder C. Bias in meta-analysis detected by a simple, graphical test. BMJ 1997;315(7109):629-34. [DOI: 10.1136/bmj.315.7109.629]

\section{Eiland 2010}

Eiland LS, Hunt MO. The use of triptans for pediatric migraines. Paediatric Drugs 2010;12(6):379-89. [DOI: 10.2165/11532860-000000000-00000]

\section{Goadsby 2008}

Goadsby PJ. The 'Act when Mild' (AwM) study: a step forward in our understanding of early treatment in acute migraine. Cephalalgia 2008;28(Suppl 2):36-41. [DOI: 10.1111/ j.1468-2982.2008.01689.x]

\section{GRADEPro 2015 [Computer program]}

McMaster University (developed by Evidence Prime, Inc.) GRADEpro Guideline Development Tool. McMaster University (developed by Evidence Prime, Inc.), 2015. Available from www.gradepro.org.

\section{Harbord 2006}

Harbord RM, Egger M, Sterne JAC. A modified test for smallstudy effects in meta-analyses of controlled trials with binary endpoints. Statistics in Medicine 2006;25(20):3443-57. [DOI: 10.1002/sim.2380]

\section{Higgins 2002}

Higgins JPT, Thompson SG. Quantifying heterogeneity in a meta-analysis. Statistics in Medicine 2002;21(11):1539-58. [DOI: 10.1002/sim.1186]

\section{Higgins 2011}

Higgins JPT, Green S (editors). Cochrane Handbook for Systematic Reviews of Interventions Version 5.1.0 [updated March 2011]. The Cochrane Collaboration, 2011. Available from: www.cochrane-handbook.org. 


\section{ICHD-2}

Headache Classification Subcommittee of the International Headache Society. The International Classification of Headache Disorders, 2nd edition. Cephalalgia 2004;24(1 Suppl):1-160. [DOI: 10.1111/j.1468-2982.2003.00823.x]

\section{ICHD-3 beta}

Headache Classification Committee of the International Headache Society. The International Classification of Headache Disorders, 3rd edition (beta version). Cephalalgia 2013;33(9):629-808. [DOI: 10.1177/0333102413485658]

\section{IHS 1988}

International Headache Society. Classification and diagnostic criteria for headache disorders, cranial neuralgias, and facial pain. Cephalalgia 1988;8(Suppl 7):1-96.

\section{Lathyris 2007}

Lathyris DN, Trikalinos TA, Ioannidis JP. Evidence from crossover trials: empirical evaluation and comparison against parallel arm trials. International Journal of Epidemiology 2007;36(2):422-30. [DOI: 10.1093/ije/dym001]

\section{Levy 2008}

Levy D, Zhang X-C, Jakubowski M, Burstein R. Sensitization of meningeal nociceptors: inhibition by naproxen. European Journal of Neuroscience 2008;27(4):917-22. [DOI: 10.1111/ j.1460-9568.2008.06068.x]

\section{Lewis 2004}

Lewis D, Ashwal S, Hershey A, Hirtz D, Yonker M, Silberstein S. Practice parameter: pharmacological treatment of migraine headache in children and adolescents: report of the American Academy of Neurology Quality Standards Subcommittee and the Practice Committee of the Child Neurology Society. Neurology 2004;63(12):2215-24. [DOI: 10.1212/01.WNL.0000147332.41993.90]

\section{Lipton 2002}

Lipton RB, Hamelsky SW, Dayno JM. What do patients with migraine want from acute migraine treatment? Headache 2002;42(Suppl 1):3-9. [PMID: 11966858]

\section{Major 2003}

Major PW, Grubisa HSI, Thie NMR. Triptans for treatment of acute pediatric migraine: a systematic literature review. Pediatric Neurology 2003;29(5):425-9. [DOI: 10.1016/ S0887-8994(03)00400-4]

\section{Pierce 2010}

Pierce CA, Voss B. Efficacy and safety of ibuprofen and acetaminophen in children and adults: a meta-analysis and qualitative review. Annals of Pharmacotherapy 2010;44(3):489-506. [DOI: 10.1345/aph.1M332]

\section{Powers 2003}

Powers SW, Patton SR, Hommel KA, Hershey AD. Quality of life in childhood migraines: clinical impact and comparison to other chronic illnesses. Pediatrics 2003;112(1 Pt 1):e1-5. [PMID: 12837897]

\section{Powers 2004}

Powers SW, Patton SR, Hommel KA, Hershey AD. Quality of life in paediatric migraine: characterization of age-related effects using PedsQL 4.0. Cephalalgia 2004;24(2):120-7. [DOI: 10.1111/ j.1468-2982.2004.00652.x]

\section{RevMan 2014 [Computer program]}

Review Manager. Version 5.3. The Nordic Cochrane Centre, Copenhagen: Cochrane, 2014.

\section{Silver 2008}

Silver S, Gano D, Gerretsen P. Acute treatment of paediatric migraine: a meta-analysis of efficacy. Journal of Paediatrics \& Child Health 2008;44(1-2):3-9. [DOI: 10.1111/ j.1440-1754.2007.01206.x]

\section{Stata 14 [Computer program]}

Stata Statistical Software: Release 14. StataCorp. College Station, TX: StataCorp LP, 2015.

\section{Stovner 2007}

Stovner LJ, Hagen K, Jensen R, Katsarava Z, Lipton RB, Scher AI, et al. The global burden of headache: a documentation of headache prevalence and disability worldwide. Cephalalgia 2007;27(3):193-210. [DOI: 10.1111/j.1468-2982.2007.01288.x]

\section{Sun 2013}

Sun H, Bastings E, Temeck J, Men A, Tandon V, Murphy D, et al. Migraine therapeutics in adolescents: a systematic analysis and historic perspectives of triptan trials in adolescents. JAMA Pediatrics 2013;167(3):243-9. [DOI: 10.1001/ jamapediatrics.2013.872]

\section{Suthisisang 2010}

Suthisisang CC, Poolsup N, Suksomboon N, Lertpipopmetha V, Tepwitukgid B. Meta-analysis of the efficacy and safety of naproxen sodium in the acute treatment of migraine. Headache 2010;50(5):808-18. [DOI: 10.1111/j.1526-4610.2010.01635.x]

\section{Tfelt-Hansen 2012}

Tfelt-Hansen P, Pascual J, Ramadan N, Dahlof C, D'Amico D, Diener $\mathrm{H}-\mathrm{C}$, et al. Guidelines for controlled trials of drugs in migraine: third edition. A guide for investigators. Cephalalgia 2012;32(1):6-38. [DOI: 10.1177/0333102411417901]

\section{Toldo 2012}

Toldo I, De Carlo D, Bolzonella B, Sartori S, Battistella PA. The pharmacological treatment of migraine in children and adolescents: an overview. Expert Review of Neurotherapeutics 2012;12(9):1133-42. [DOI: 10.1586/ern.12.104]

\section{Vollono 2011}

Vollono C, Vigevano F, Tarantino S, Valeriani M. Triptans other than sumatriptan in child and adolescent migraine: literature review. Expert Review of Neurotherapeutics 2011;11(3):395-401. [DOI: 10.1586/ern.10.147]

\section{Winner 1995}

Winner P, Martinez W, Mate L, Bello L. Classification of pediatric migraine: proposed revisions to the IHS criteria. Headache 1995;35(7):407-10 


\section{Wöber-Bingöl 2013}

Wöber-Bingöl Ç. Pharmacological treatment of acute migraine in adolescents and children. Paediatric Drugs 2013;15(3):235-46. [DOI: 10.1007/s40272-013-0019-3]

\section{References to other published versions of this review}

\section{Richer 2009}

Richer LP. Practice Variation in the Treatment of Children with Migraine in the Emergency Department [MSC Thesis]. Edmonton, AB: University of Alberta, 2009.

* Indicates the major publication for the study

\section{CHARACTERISTICS OF STUDIES}

Characteristics of included studies [ordered by study ID]

Ahonen 2004

\section{Study characteristics}

\begin{tabular}{|c|c|}
\hline Methods & Randomized, double-blind, placebo-controlled, two-way cross-over trial of sumatriptan nasal spray \\
\hline \multirow[t]{2}{*}{ Participants } & $\begin{array}{l}\text { Children and adolescents } 8-17 \text { years and body weight } \geq 20 \mathrm{~kg} \text { with a diagnosis of migraine with or with- } \\
\text { out aura meeting the IHS } 1988 \text { criteria from } 3 \text { pediatric hospitals in Finland. Participants were expect- } \\
\text { ed to have least } 2 \text { migraine attacks per month lasting } 4 \mathrm{~h} \text { and demonstrated resistance to usual therapy } \\
\text { for migraine with paracetamol or nonsteroidal anti-inflammatory drugs (NSAIDs). No participants were } \\
\text { receiving preventive medication. }\end{array}$ \\
\hline & $\begin{array}{l}\text { Randomized }(N=129) \text {; medication not used }(N=35) ; 1 \text { medication used }(N=11) \text {; intention-to-treat } \\
\text { analysis }(N=94) \text {; primary efficacy analysis }(N=83)\end{array}$ \\
\hline Interventions & $\begin{array}{l}\text { Sumatriptan nasal spray } 10 \mathrm{mg} \text { (weight } 20 \text { to } 39 \mathrm{~kg} \text { ) or } 20 \mathrm{mg} \text { ( } \geq 40 \mathrm{~kg} \text { ) versus placebo. Children were } \\
\text { instructed to take a single nasal insufflation at the onset of a migraine attack if headache severity was } \\
\text { classified as } \geq 3 \text { on a } 5 \text {-faces pain intensity scale. Each participant treated } 2 \text { migraine attacks - } 1 \text { with } \\
\text { placebo and the other with sumatriptan. Rescue medications were allowed at any point. }\end{array}$ \\
\hline \multirow[t]{2}{*}{ Outcomes } & $\begin{array}{l}\text { - Headache relief at } 2 \mathrm{~h} \text { (defined as severe or moderate (a grade of } \geq 3 \text { ) to at least } 2 \text { grades lower or fell } \\
\text { asleep during these } 2 \mathrm{~h} \text { and was pain-free on awakening) } \\
\text { - Pain-free at } 2 \mathrm{~h} \\
\text { - Use of rescue medication } \\
\text { - Adverse events }\end{array}$ \\
\hline & $\begin{array}{l}\text { Other reported outcomes: } \\
\text { - Headache relief and pain-free at } 1,3 \text {, and } 4 \mathrm{~h} \text { after treatment } \\
\text { - Participant preference }\end{array}$ \\
\hline
\end{tabular}

Headache severity scale 5-faces pain scale ( 5 severe, 4 to 3 moderate, 2 mild, 1 no pain)

\begin{tabular}{ll}
\hline Funding source & GlaxoSmithKline \\
\hline Publication & Journal
\end{tabular}

Notes All children who had used at least 1 treatment were included in the intention-to-treat analysis

\section{Risk of bias}

\begin{tabular}{lll}
\hline Bias & Authors' judgement & Support for judgement \\
\hline $\begin{array}{l}\text { Random sequence genera- } \\
\text { tion (selection bias) }\end{array}$ & Low risk & Quote: "Randomization was done in the hospital pharmacy" \\
\hline
\end{tabular}


Ahonen 2004 (Continued)

$\begin{array}{ll}\begin{array}{l}\text { Allocation concealment } \\ \text { (selection bias) }\end{array} & \text { Quote: "The randomization code was stored by one of the authors who did } \\ \text { not meet any of the patients, and it was not broken until the database of treat- } \\ \text { ment efficacy was created and locked" }\end{array}$

\begin{tabular}{ll}
\hline Blinding (performance & Low risk \\
bias and detection bias) & Quote: "study drugs of identical appearance"; "indistinguishable". \\
All outcomes & $\begin{array}{l}\text { Comment: Probably done, since both preparations were supplied by Glax- } \\
\text { oSmithKline }\end{array}$
\end{tabular}

\begin{tabular}{lll}
\hline $\begin{array}{l}\text { Incomplete outcome data } \\
\text { (attrition bias) }\end{array}$ & Low risk & Comment: study drug and placebo groups were balanced \\
All outcomes & & \\
\hline $\begin{array}{l}\text { Selective reporting (re- } \\
\text { porting bias) }\end{array}$ & Low risk & Comment: all primary outcomes were reported \\
\hline
\end{tabular}

\section{Ahonen 2006}

\section{Study characteristics}

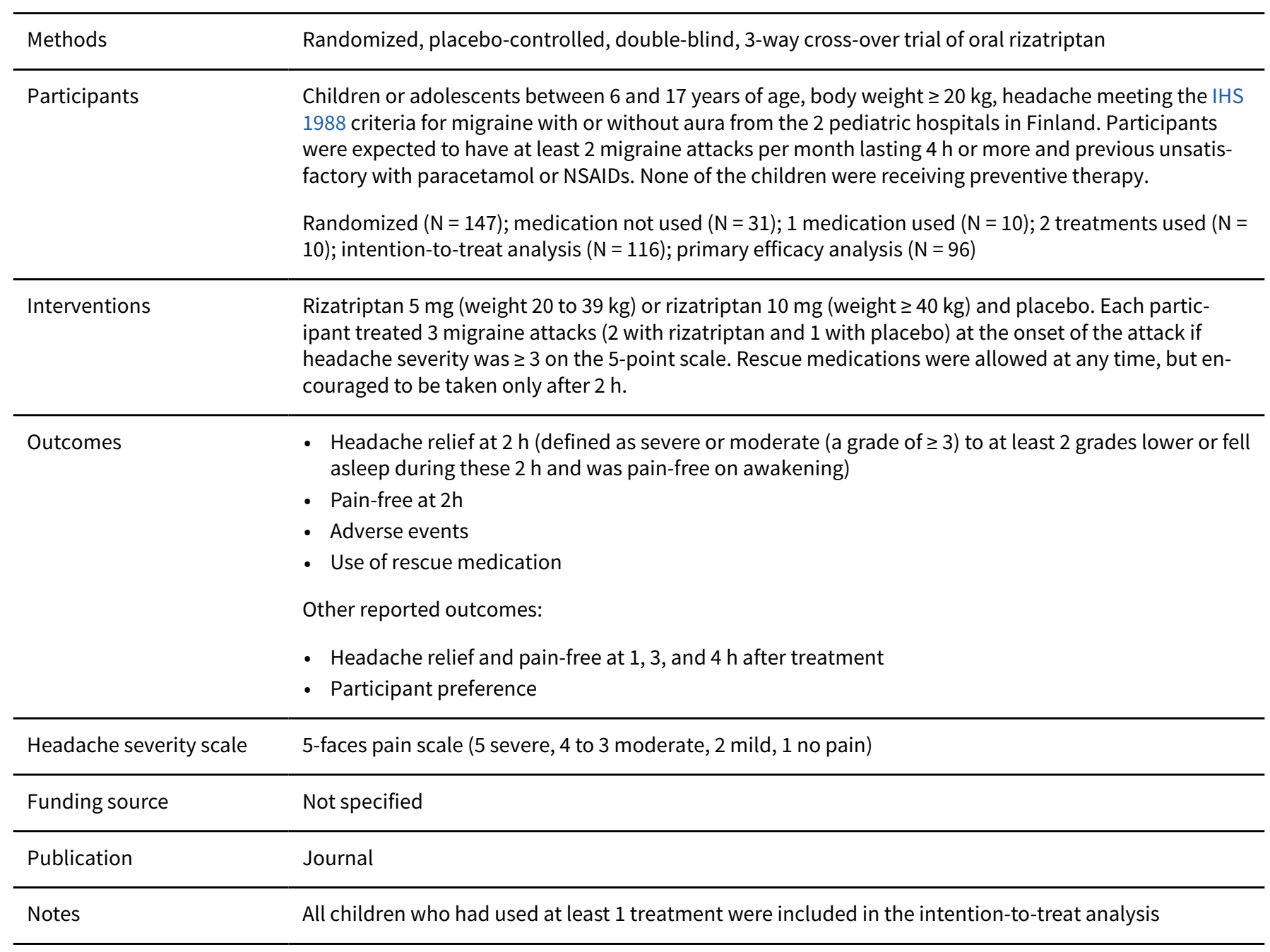

\section{Risk of bias}


Ahonen 2006 (Continued)

\begin{tabular}{lll} 
Bias & Authors' judgement & Support for judgement \\
\hline $\begin{array}{l}\text { Random sequence genera- } \\
\text { tion (selection bias) }\end{array}$ & Low risk & Quote: "tossing a coin method" \\
\hline $\begin{array}{l}\text { Allocation concealment } \\
\text { (selection bias) }\end{array}$ & Low risk & $\begin{array}{l}\text { Quote: "Randomization was done in the hospital pharmacy"; "randomization } \\
\text { code was stored by one of the authors... was not broken until the database of } \\
\text { treatment efficacy was created and locked" }\end{array}$ \\
\hline
\end{tabular}

Blinding (performance Low risk Quote: "drugs packed in capsules of identical appearance"
bias and detection bias)
All outcomes

\begin{tabular}{lll}
\hline $\begin{array}{l}\text { Incomplete outcome data } \\
\text { (attrition bias) }\end{array}$ & Low risk & \\
All outcomes & & \\
\hline $\begin{array}{l}\text { Selective reporting (re- } \\
\text { porting bias) }\end{array}$ & Low risk & Comment: all expected outcomes reported \\
\hline
\end{tabular}

\section{Callenbach 2007}

\section{Study characteristics}

\begin{tabular}{|c|c|}
\hline Methods & Randomized, double-blind, placebo-controlled, cross-over, 2-attack study of sumatriptan nasal spray \\
\hline \multirow[t]{2}{*}{ Participants } & $\begin{array}{l}\text { Participants from } 18 \text { centres in the Netherlands were } 12-17 \text { years of age with a diagnosis of migraine } \\
\text { with or without aura per revised IHS } 1988 \text { criteria (Winner 1995) whom had failed, or responded inade- } \\
\text { quately, to at least } 1 \text { over the counter or prescription medication for migraine, duration typically longer } \\
\text { than } 4 \text { hours if untreated, and between } 1 \text { and } 8 \text { attacks per month in each of the } 2 \text { months before enrol- } \\
\text { ment }\end{array}$ \\
\hline & Randomized $(N=66)$; withdrawn $(N=20)$; analyzed $(N=46)$ \\
\hline
\end{tabular}

Interventions

Each participant treated 2 attacks - 1 with sumatriptan nasal spray ( $10 \mathrm{mg}$ if $<40 \mathrm{~kg}$ or $20 \mathrm{mg}$ if $>40 \mathrm{~kg}$ ) and 1 with placebo nasal spray. Recurrence within $2-24 \mathrm{~h}$ could be treated with a second dose.

\begin{tabular}{ll}
\hline Outcomes & - Headache relief at $2 \mathrm{~h}$ \\
& - Pain free at $2 \mathrm{~h}$ \\
& - Presence of nausea, \\
& - Udve of rescue medication \\
& - Recurrence of migraine within 2-2h $\mathrm{h}$ \\
& Other reported outcomes: \\
& - Headache relief, pain free, nausea, vomiting, photophobia, and phonophobia at 15, 30, and 60 min \\
\hline Headache severity scale & 4-point scale (none, mild, moderate, severe) \\
\hline Funding source & GlaxoSmithKline \\
\hline Publication & Journal and Clinical Trial Registry \\
\hline Notes & - \\
\hline
\end{tabular}


Callenbach 2007 (Continued)

Risk of bias

\begin{tabular}{lll}
\hline Bias & Authors' judgement & Support for judgement \\
\hline $\begin{array}{l}\text { Random sequence genera- } \\
\text { tion (selection bias) }\end{array}$ & Unclear risk & Quote: "in a randomized order" \\
& & $\begin{array}{l}\text { Comment: other studies funded by GlaxoSmithKline reported acceptable se- } \\
\text { quence generation (e.g. Winner 2007) }\end{array}$ \\
\hline $\begin{array}{l}\text { Allocation concealment } \\
\text { (selection bias) }\end{array}$ & Unclear risk & Comment: no information provided \\
\hline $\begin{array}{l}\text { Blinding (performance } \\
\text { bias and detection bias) } \\
\text { All outcomes }\end{array}$ & Unclear risk & Comment: no information provided \\
\hline $\begin{array}{l}\text { Incomplete outcome data } \\
\text { (attrition bias) } \\
\begin{array}{l}\text { All outcomes } \\
\text { Selective reporting (re- }\end{array}\end{array}$ & Low risk & Comment: withdrawals balanced across intervention groups \\
\hline \begin{tabular}{l} 
porting bias) \\
\hline
\end{tabular} & & Comment: all expected outcomes reported \\
\hline
\end{tabular}

Derosier 2012

\section{Study characteristics}

\begin{tabular}{|c|c|}
\hline Methods & $\begin{array}{l}\text { Outpatient, double-blind, randomized, placebo-controlled, parallel group trial with an enrichment de- } \\
\text { sign of oral sumatriptan + naproxen sodium }\end{array}$ \\
\hline \multirow[t]{2}{*}{ Participants } & $\begin{array}{l}\text { Eligible participants were } 12 \text { to } 17 \text { years old at screening and had }>6 \text { months history of } 2 \text { to } 8 \text { migraine } \\
\text { attacks per month (with or without aura: ICHD-2), typically lasting }>3 \mathrm{~h} \text { and associated with moderate } \\
\text { to severe headache pain. Triptan-naive subjects were eligible. }\end{array}$ \\
\hline & $\begin{array}{l}\text { Run-in phase }(N=976) \text {; Randomized }(N=589) \text {; Medication not used }(N=57) \text {; Withdrawn }(N=42) \text {; inten- } \\
\text { tion-to-treat and primary efficacy analysis }(N=490)\end{array}$ \\
\hline Interventions & $\begin{array}{l}\text { Subjects treating } 1 \text { moderate to severe migraine with single-blind placebo during the run-in phase and } \\
\text { reporting pain } 2 \mathrm{~h} \text { post dose (placebo non responders) were randomly assigned into the double-blind } \\
\text { phase. In the double-blind phase, subjects treated } 1 \text { moderate to severe migraine with either matching } \\
\text { placebo or sumatriptan + naproxen sodium } 10 \mathrm{mg}+60 \mathrm{mg}, 30 \mathrm{mg}+180 \mathrm{mg} \text {, or } 85 \mathrm{mg}+500 \mathrm{mg} \text {. }\end{array}$ \\
\hline \multirow[t]{3}{*}{ Outcomes } & $\begin{array}{l}\text { - Pain-free at } 2 \mathrm{~h} \text { post-treatment in the double-blind phase (absence of headache pain post-treatment } \\
\text { from moderate or severe at baseline, without previous use of rescue medication) } \\
\text { - Nausea free at } 2 \mathrm{~h} \\
\text { - Use of rescue medication within } 2-24 \mathrm{~h}\end{array}$ \\
\hline & Other reported outcomes: \\
\hline & - Sustained freedom from pain, photophobia, phonophobia, and nausea from 2-24 h post-treatment \\
\hline Headache severity scale & 4-level pain scale (none, mild, moderate, severe) \\
\hline Funding source & GlaxoSmithKline \\
\hline Publication & Journal and Clinical Trial Registry \\
\hline
\end{tabular}


Derosier 2012 (Continued)

Notes Single-blind run-in phase (enrichment design) assessment was at $2 \mathrm{~h}$

\section{Risk of bias}

\begin{tabular}{lll}
\hline Bias & Authors' judgement & Support for judgement \\
\hline $\begin{array}{ll}\text { Random sequence genera- } \\
\text { tion (selection bias) }\end{array}$ & Unclear risk & $\begin{array}{l}\text { Quote: "Upon determination of subject eligibility and completion of the ran- } \\
\text { domizations visit, site staff telephoned an interactive voice response system } \\
\text { and dispensed randomly assigned, age-group stratified treatment." }\end{array}$ \\
\hline
\end{tabular}

\begin{tabular}{lll}
\hline $\begin{array}{l}\text { Allocation concealment } \\
\text { (selection bias) }\end{array}$ & Low risk & Comment: used interactive voice response system for randomization \\
\hline $\begin{array}{l}\text { Blinding (performance } \\
\text { bias and detection bias) }\end{array}$ & Unclear risk & $\begin{array}{l}\text { Parent/guardian and subject were informed that they would not know which } \\
\text { study drug was provided for the first or second migraine treated, and that the } \\
\text { investigator would not know which study drug was provided for the second } \\
\text { migraine treated. To maintain blinding, sites received education on describing } \\
\text { the single-blind phase. }\end{array}$
\end{tabular}

\begin{tabular}{|c|c|c|}
\hline $\begin{array}{l}\text { Incomplete outcome data } \\
\text { (attrition bias) }\end{array}$ & Low risk & $\begin{array}{l}\text { Comment: withdrawals and reasons for withdrawal (outlined in Figure } 1 \text { of } \\
\text { Derosier 2012) were balanced between groups }\end{array}$ \\
\hline
\end{tabular}

All outcomes

Selective reporting (re- Low risk Comment: all expected outcomes were reported
porting bias)

porting bias)

Evers 2006

\section{Study characteristics}

Methods

Double-blind, placebo-controlled, cross-over study to investigate the efficacy of oral zolmitriptan in the treatment of migraine attacks in children and adolescents

Participants

Children and adolescents aged 6-18 years from an headache outpatient clinic (not reported separately) Migraine with and without aura according to the criteria of the ICHD-2

No neurologic, psychiatric, and vascular disorder

Randomized ( $\mathrm{N}=32)$; withdrawn ( $\mathrm{N}=3)$; intention-to-treat and primary efficacy analysis $(\mathrm{N}=29)$

\begin{tabular}{ll}
\hline Interventions & Ibuprofen $200 \mathrm{mg}$ PO (children under 12) or $400 \mathrm{mg}$ PO (adolescents) \\
& Zolmitriptan $2.5 \mathrm{mg}$ PO \\
\hline Outcomes & Pain relief (defined as no or mild headache after moderate or severe headache) after $2 \mathrm{~h}$ \\
- Pain free after $2 \mathrm{~h}$ \\
- Headache recurrence and use of rescue medication within $24 \mathrm{~h}$ \\
- Nausea and vomiting after $2 \mathrm{~h}$ \\
- All adverse events classified (probably/possibly drug related or not drug related) \\
Other reported outcomes: \\
- Pain-free and headache relief after $0.5,1,4$, and $24 \mathrm{~h}$ \\
- Headache recurrence, sustained pain-free response, frequency of accompanying symptoms (nausea, \\
vomiting, photophobia, phonophobia) after $0.5,1,3$, and $24 \mathrm{~h}$
\end{tabular}


Evers 2006 (Continued)

Headache severity scale $\quad$ 4-point scale (none, mild, moderate, severe)

\begin{tabular}{ll}
\hline Funding source & Not clear \\
\hline Publication & Journal \\
\hline Notes & - \\
\hline
\end{tabular}

\section{Risk of bias}

\begin{tabular}{|c|c|c|}
\hline Bias & Authors' judgement & Support for judgement \\
\hline $\begin{array}{l}\text { Random sequence genera- } \\
\text { tion (selection bias) }\end{array}$ & Unclear risk & Quote: "The order of the study drugs was randomized for every patient." \\
\hline $\begin{array}{l}\text { Allocation concealment } \\
\text { (selection bias) }\end{array}$ & Low risk & $\begin{array}{l}\text { Comment: cross-over study where each participant received the study drugs in } \\
\text { random order }\end{array}$ \\
\hline $\begin{array}{l}\text { Blinding (performance } \\
\text { bias and detection bias) } \\
\text { All outcomes }\end{array}$ & Unclear risk & Comment: blinding was not reported \\
\hline $\begin{array}{l}\text { Incomplete outcome data } \\
\text { (attrition bias) } \\
\text { All outcomes }\end{array}$ & Low risk & $\begin{array}{l}\text { Comment: } 3 \text { of } 32 \text { participants dropped out (withdrawal of consent } N=2 \text { ) lost } \\
\text { to follow-up } N=1 \text { ) }\end{array}$ \\
\hline $\begin{array}{l}\text { Selective reporting (re- } \\
\text { porting bias) }\end{array}$ & Low risk & Comment: aAll primary and secondary outcomes were reported \\
\hline
\end{tabular}

Fujita 2014

\section{Study characteristics}

\begin{tabular}{ll}
\hline Methods $\quad$ Randomized, double-blind, placebo-controlled, parallel group trial of oral sumatriptan \\
\hline
\end{tabular}

Participants

Participants from 17 centres in Japan were 10-17 years of age, diagnosed with migraine with or without aura per ICHD-2 criteria for a minimum of 6 months, and 2-8 attacks monthly lasting for $>3 \mathrm{~h}$ in the last 2 months prior to entry.

Randomized ( $\mathrm{N}=178)$; withdrawn $(\mathrm{N}=34)$; intention-to-treat and primary efficacy analysis $(\mathrm{N}=144)$

Interventions Oral sumatriptan $25 \mathrm{mg}$ (1 tablet and 1 matching placebo), sumatriptan $50 \mathrm{mg}$ (2 tablets), or placebo (2 tablets) taken as soon as possible (within 30 minutes) after the development of a migraine with grade 3 or more pain

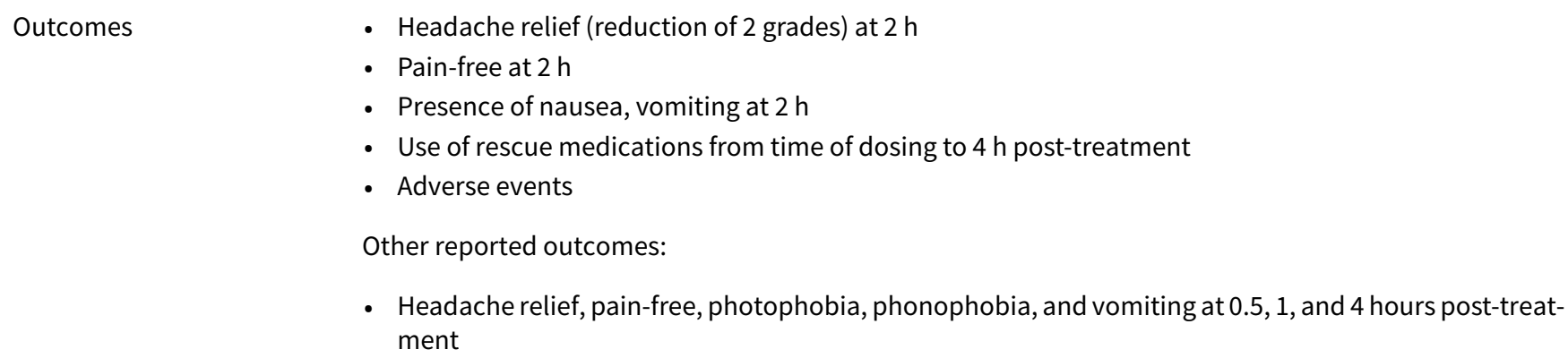

- Pain-free at $2 \mathrm{~h}$

- Presence of nausea, vomiting at $2 \mathrm{~h}$

- Use of rescue medications from time of dosing to $4 \mathrm{~h}$ post-treatment

- Adverse events

Other reported outcomes:

- Headache relief, pain-free, photophobia, phonophobia, and vomiting at $0.5,1$, and 4 hours post-treatment 
Fujita 2014 (Continued)

Headache severity scale $\quad 5$-grade scale

\begin{tabular}{ll}
\hline Funding source & GlaxoSmithKline \\
\hline Publication & Journal and Clinical Trial Registry \\
\hline Notes & - \\
\hline
\end{tabular}

\section{Risk of bias}

\begin{tabular}{|c|c|c|}
\hline Bias & Authors' judgement & Support for judgement \\
\hline $\begin{array}{l}\text { Random sequence genera- } \\
\text { tion (selection bias) }\end{array}$ & Low risk & $\begin{array}{l}\text { Quote: "Investigator (or subinvestigator) completed the registration form and } \\
\text { sent it to the randomization center by facsimile. The randomization center... } \\
\text { assigned a randomization number to the patient." }\end{array}$ \\
\hline $\begin{array}{l}\text { Allocation concealment } \\
\text { (selection bias) }\end{array}$ & Low risk & $\begin{array}{l}\text { Quote: "For allocation of the participants, a computer-generated list of ran- } \\
\text { dom numbers was used." }\end{array}$ \\
\hline $\begin{array}{l}\text { Blinding (performance } \\
\text { bias and detection bias) } \\
\text { All outcomes }\end{array}$ & Low risk & $\begin{array}{l}\text { Quote: "The investigator (or subinvestigator) dispensed the investigational } \\
\text { product to the patient according to the computer-generated randomization } \\
\text { number." }\end{array}$ \\
\hline $\begin{array}{l}\text { Incomplete outcome data } \\
\text { (attrition bias) } \\
\text { All outcomes }\end{array}$ & Low risk & Comment: used last observation carried forward (LOCF) \\
\hline $\begin{array}{l}\text { Selective reporting (re- } \\
\text { porting bias) }\end{array}$ & Low risk & Comment: all stated outcomes were reported \\
\hline
\end{tabular}

Ho 2012

\section{Study characteristics}

\begin{tabular}{ll}
\hline Methods & $\begin{array}{l}\text { Randomized, double-blind, placebo-controlled, parallel group trial of oral rizatriptan with an enrich- } \\
\text { ment design }\end{array}$
\end{tabular}
ment design

Participants

Participants were males and females aged $6-17$ years who were $\geq 20 \mathrm{~kg}$ in weight and who had at least a 6-month history of migraine attacks with or without aura as defined by ICHD-2, usually lasting $3 \mathrm{~h}$ or more (when untreated). Participants had $\geq 1$ and $\leq 8$ moderate to severe migraine attacks with or without aura per month in the 2 months before the screening visit, and had not, by history, experienced satisfactory relief with NSAIDs or paracetamol. Patients were excluded if they had not experienced satisfactory relief from migraine pain during prior treatment with 2 or more adequate courses of triptans. Non-responders to placebo in stage 1 were randomized 1:1 to rizatriptan:placebo, with randomization stratified by age (6-11 years versus $12-17$ years).

Randomized ( $\mathrm{N}=1382)$; not treated $(\mathrm{N}=405)$; randomized in stage $1(\mathrm{~N}=915)$; randomized in stage $2(\mathrm{~N}$ =791); withdrawn $(\mathrm{N}=21)$; intention-to-treat and primary efficacy analysis $(\mathrm{N}=770)$

Interventions

Oral-disintegrating tablet of rizatriptan $5 \mathrm{mg}(<40 \mathrm{~kg})$ or $10 \mathrm{mg}(\geq 40 \mathrm{~kg})$ or placebo. Participants treated within $30 \mathrm{~min}$ of a moderate/severe migraine attack. In stage 1, participants were randomized 20:1 to placebo or rizatriptan. In stage 2, participants with ongoing moderate/severe pain after 15 min (nonresponders) who received placebo in stage 1 were randomized 1:1 to rizatriptan or placebo.

$\begin{array}{ll}\text { Outcomes } & \text { Pain-free at } 2 \mathrm{~h} \\ \text { - } & \text { Pain relief (reduction of at least } 2 \text { grades from baseline) at } 2 \mathrm{~h}\end{array}$


Ho 2012 (Continued)

- Vomiting, nausea free at $2 \mathrm{~h}$

- Use of rescue medications within $24 \mathrm{~h}$

- Adverse events

Other reported outcomes:

- Sustained pain-free 24 and 48 h post-treatment

- Photophobia-free, phonophobia-free at $2 \mathrm{~h}$

\begin{tabular}{ll}
\hline Headache severity scale & 4-point scale (none, mild, moderate, severe) \\
\hline Funding source & Merck \\
\hline Publication & Journal and abstract \\
\hline Notes & - \\
\hline
\end{tabular}

\section{Risk of bias}

\begin{tabular}{lll}
\hline Bias & Authors' judgement & Support for judgement \\
\hline $\begin{array}{l}\text { Random sequence genera- } \\
\text { tion (selection bias) }\end{array}$ & Unclear risk & Comment: randomization process not described \\
\hline $\begin{array}{l}\text { Allocation concealment } \\
\text { (selection bias) }\end{array}$ & Unclear risk & Comment: allocation performed using interactive voice response system \\
\hline $\begin{array}{l}\text { Blinding (performance } \\
\text { bias and detection bias) } \\
\text { All outcomes }\end{array}$ & Unclear risk & Comment: no information provided \\
\hline $\begin{array}{l}\text { Incomplete outcome data } \\
\text { (attrition bias) } \\
\text { All outcomes }\end{array}$ & Low risk & Comment: withdrawals are balanced between intervention groups \\
\hline $\begin{array}{l}\text { Selective reporting (re- } \\
\text { porting bias) }\end{array}$ & Low risk & Comment: all expected outcomes reported including adverse events \\
\hline
\end{tabular}

\section{Hämäläinen 1997a}

\section{Study characteristics}

$\begin{array}{ll}\text { Methods } & \begin{array}{l}\text { Randomized, double-blind, placebo-controlled, 3-way cross-over trial of ibuprofen, paracetamol, and } \\ \text { placebo }\end{array}\end{array}$

Participants

Children or adolescents $<18$ years with a diagnosis of migraine with or without aura meeting IHS 1988 criteria from 3 pediatric hospitals in the Greater Helsinki Area of Finland who found previous therapy for migraine unsatisfactory. Participants were required to have 2 migraine attacks per month lasting 2 hor more.

Randomized ( $N=106)$; lost to follow-up $(\mathrm{N}=2)$; medication not used $(\mathrm{N}=16) ; 1$ medication used $(\mathrm{N}=$ 5); 2 medications used ( $N=8)$; withdrawn $(N=9)$; intention-to-treat analysis ( $N=88)$; primary efficacy analysis $(\mathrm{N}=66)$

Interventions Each participant treated 1 of 3 migraine attacks with either oral paracetamol ( $15 \mathrm{mg} / \mathrm{kg}$ ), oral ibuprofen $(10 \mathrm{mg} / \mathrm{kg})$, or placebo. The active drugs and matching placebo were supplied by the University 
Hämäläinen 1997a (Continued)

Pharmacy of Helsinki in 3 mixtures containing peppermint water, black currant syrup, sugar syrup, and either $30 \mathrm{mg} / \mathrm{ml}$ paracetamol or $20 \mathrm{mg} / \mathrm{ml}$ ibuprofen, or, as a placebo, cellulose. Each participant received a package of 3 identically numbered bottles and a plastic $10 \mathrm{ml}$ syringe for exact weight-based dosing $(0.5 \mathrm{ml} / \mathrm{kg}$, maximum dose $30 \mathrm{ml})$.

- Headache relief at $2 \mathrm{~h}$ (defined as severe or moderate (a grade of $\geq 3$ ) to at least 2 grades lower
- Pain-free at $2 \mathrm{~h}$
- Use of rescue medication within $2 \mathrm{~h}$
- Adverse events
Other reported outcomes:
- Headache relief and pain-free at $1 \mathrm{~h}$ after treatment
- Patient preference

$\begin{array}{ll}\text { Headache severity scale } & \text { Participants were allowed to choose between the 5-faces pain scale (5 severe, } 4 \text { to } 3 \text { moderate, } 2 \text { mild, } 1 \\ \text { no pain) or the } 100 \mathrm{~mm} \text { visual analogue scale (VAS). The VAS (0 to 100) data were transformed to a nom- } \\ \text { inal scale: grade } 1: 0 \text { to } \leq 12 \text {; grade 2: } 12 \text { to } \leq 37 \text {; grade } 3: 37 \text { to } \leq 62 \text {; grade } 4: 62 \text { to } \leq 87 \text {; and grade 5: } 87 \text { to } \\ \leq 100\end{array}$

\begin{tabular}{ll}
\hline Funding source & Not specified \\
\hline Publication & Journal \\
\hline Notes & $\begin{array}{l}\text { All additional children and adolescents with any data on efficacy were included in the intention-to- } \\
\text { treat analysis, which was performed without regard to pain intensity at the start of the attack. }\end{array}$
\end{tabular}

\section{Risk of bias}

\begin{tabular}{|c|c|c|}
\hline Bias & Authors' judgement & Support for judgement \\
\hline $\begin{array}{l}\text { Random sequence genera- } \\
\text { tion (selection bias) }\end{array}$ & Unclear risk & Comment: no information provided \\
\hline $\begin{array}{l}\text { Allocation concealment } \\
\text { (selection bias) }\end{array}$ & Unclear risk & Comment: no information provided \\
\hline $\begin{array}{l}\text { Blinding (performance } \\
\text { bias and detection bias) } \\
\text { All outcomes }\end{array}$ & Low risk & $\begin{array}{l}\text { Quote: "[T]he active drugs and matching placebo were supplied by the Uni- } \\
\text { versity Pharmacy of Helsinki in three mixtures containing peppermint wa- } \\
\text { ter, black currant syrup, sugar syrup, and either } 30 \mathrm{mg} / \mathrm{ml} \text { paracetamol or } 20 \\
\mathrm{mg} / \mathrm{ml} \text { ibuprofen, or as placebo (cellulose). Each participant received a pack- } \\
\text { age of three identically numbered bottles and a plastic } 10 \mathrm{ml} \text { syringe for exact } \\
\text { weight-based dosing }(0.5 \mathrm{ml} / \mathrm{kg} \text {; max } 30 \mathrm{ml}) . "\end{array}$ \\
\hline
\end{tabular}

Incomplete outcome data Low risk Comment: missing outcome data balanced across intervention groups
(attrition bias)

All outcomes

Selective reporting (re- Low risk Comment: all expected outcomes reported
porting bias)

\section{Hämäläinen 1997b}

\section{Study characteristics}

Methods Randomized, double-blind, placebo-controlled, 2-way cross-over trial of oral sumatriptan


Hämäläinen 1997b (Continued)

Participants

Children or adolescents 8-17 years with a diagnosis of migraine with or without aura meeting IHS 1988 criteria from 3 pediatric hospitals in the Greater Helsinki Area of Finland who had not benefited from previous migraine therapy. Participants were required to have 2 migraine attacks per month. None of the participants were using preventive therapy, but had already participated in previous placebo-controlled trials with paracetamol and ibuprofen, dihydroergotamine, or both.

Randomized ( $N=31)$; medication not used $(N=4) ; 1$ medication used $(N=3)$; withdrawn $(N=1)$; primary efficacy analysis $(\mathrm{N}=23)$

Interventions

Each participant treated 1 migraine attack at home with oral sumatriptan (50 mg for a body surface area of $0.75-1.5 \mathrm{~m}^{2}$ ( 6-12 years of age) and $100 \mathrm{mg}$ for a body surface area greater than $1.5 \mathrm{~m}^{2}(\sim>12$ years of age) and 1 migraine attack with placebo in a randomized order. Rescue medications were permitted at any time.

\begin{tabular}{ll}
\hline Outcomes & - Headache relief at $2 \mathrm{~h}$ (defined as a reduction in pain intensity by at least 50\%) \\
- Pain-free at $2 \mathrm{~h}$ & - Use of rescue medication \\
- Adverse events & Other reported outcomes: \\
& $\begin{array}{l}\text { - Pain intensity difference (pain intensity before drug minus pain intensity at assessment time) } \\
\text { - Summed pain intensity difference (pain intensity difference times h elapsed from previous assess- } \\
\text { ment }\end{array}$ \\
\hline Headache severity scale & 100 mm VAS \\
\hline Funding source & Arvo, Lea Ylppo Foundation, and Academy of Finland \\
\hline Publication & Journal \\
\hline Notes & -
\end{tabular}

\section{Risk of bias}

\begin{tabular}{|c|c|c|}
\hline Bias & Authors' judgement & Support for judgement \\
\hline $\begin{array}{l}\text { Random sequence genera- } \\
\text { tion (selection bias) }\end{array}$ & Unclear risk & Comment: no information provided \\
\hline $\begin{array}{l}\text { Allocation concealment } \\
\text { (selection bias) }\end{array}$ & Unclear risk & Comment: no information provided \\
\hline $\begin{array}{l}\text { Blinding (performance } \\
\text { bias and detection bias) } \\
\text { All outcomes }\end{array}$ & Low risk & Quote: "matching placebo... Each patient received two identical packages" \\
\hline $\begin{array}{l}\text { Incomplete outcome data } \\
\text { (attrition bias) } \\
\text { All outcomes }\end{array}$ & Low risk & Comment: missing outcome data balanced across intervention groups \\
\hline $\begin{array}{l}\text { Selective reporting (re- } \\
\text { porting bias) }\end{array}$ & Low risk & Comment: all expected outcomes were reported \\
\hline
\end{tabular}


Hämäläinen 1997c

\section{Study characteristics}

\begin{tabular}{|c|c|}
\hline Methods & Randomized, double-blind, placebo-controlled, 4-way cross-over trial of oral dihydroergotamine \\
\hline \multirow[t]{2}{*}{ Participants } & $\begin{array}{l}\text { Children or adolescents }<18 \text { years with a diagnosis of migraine per IHS } 1988 \text { criteria and at least } 2 \text { mi- } \\
\text { graine attacks per month. Most participants had participated in a previous trial of paracetamol and } \\
\text { ibuprofen versus placebo. }\end{array}$ \\
\hline & Randomized ( $\mathrm{N}=16) ; 1$ medication used $(\mathrm{N}=13)$; analyzed $(\mathrm{N}=12)$ \\
\hline Interventions & $\begin{array}{l}\text { Dihydroergotamine (DHE) mesylate oral solution } 2 \mathrm{mg} / \mathrm{ml} \text { and placebo. Each participant treated } 1 \text { mi- } \\
\text { graine attack at home with DHE } 20 \mu \mathrm{g} / \mathrm{kg} \text { (DHE solution } 2 \text { drops } / 10 \mathrm{~kg} \text { ) and } 1 \text { with placebo. If the first } \\
\text { dose provided any relief, a second dose could be taken after } 1 \mathrm{~h} \text {. If neither treatment produced an ade- } \\
\text { quate response, } 1 \text { further migraine attack was treated with } \mathrm{DHE} 40 \mu \mathrm{g} / \mathrm{kg} \text { and } 1 \text { with placebo after con- } \\
\text { tact with the investigator. }\end{array}$ \\
\hline \multirow[t]{6}{*}{ Outcomes } & - Headache relief at $2 \mathrm{~h}$ (reduction of severe or moderate pain by at least 2 grades) \\
\hline & - Pain-free at $2 \mathrm{~h}$ \\
\hline & - Use of rescue medications \\
\hline & - Adverse events \\
\hline & Other reported outcomes: \\
\hline & - Patient preference \\
\hline Headache severity scale & 5-point scale ( 5 severe, $3-4$ moderate, 2 mild, 1 no pain) \\
\hline Funding source & Not specified \\
\hline Publication & Journal \\
\hline Notes & - \\
\hline
\end{tabular}

\section{Risk of bias}

\begin{tabular}{lll}
\hline Bias & Authors' judgement & Support for judgement \\
\hline $\begin{array}{l}\text { Random sequence genera- } \\
\text { tion (selection bias) }\end{array}$ & Unclear risk & Comment: no information provided \\
\hline $\begin{array}{l}\text { Allocation concealment } \\
\text { (selection bias) }\end{array}$ & Unclear risk & Comment: no information provided \\
\hline $\begin{array}{l}\text { Blinding (performance } \\
\text { bias and detection bias) } \\
\text { All outcomes }\end{array}$ & Unclear risk & Quote: "each patient received two identical bottles" \\
\hline $\begin{array}{l}\text { Incomplete outcome data } \\
\text { (attrition bias) } \\
\text { All outcomes }\end{array}$ & Unclear risk & Comment: the taste may have been different between the bottles \\
\hline $\begin{array}{l}\text { Selective reporting (re- } \\
\text { porting bias) }\end{array}$ & Low risk & Comment: patients who were excluded were not described \\
\hline
\end{tabular}


Hämäläinen 2002

\section{Study characteristics}

\begin{tabular}{|c|c|}
\hline Methods & $\begin{array}{l}\text { Randomized, double-blind, placebo-controlled, single attack cross-over trial of sumatriptan nasal } \\
\text { spray }\end{array}$ \\
\hline \multirow[t]{2}{*}{ Participants } & $\begin{array}{l}\text { Participants from } 1 \text { center in Germany were children 8-12 years of age with 6-month history of migraine } \\
\text { with or without aura per IHS } 1988 \text { criteria, an attack frequency of 2-8 monthly, and minimum duration } \\
\text { of } 4 \mathrm{~h} \text {. }\end{array}$ \\
\hline & $\begin{array}{l}\text { Randomized }(N=60) \text {; withdrawn }(N=3) \text {; intention-to-treat analysis and primary efficacy analysis }(N= \\
\text { 59) }\end{array}$ \\
\hline Interventions & $\begin{array}{l}\text { Each participant treated } 1 \text { migraine attack with nasal sumatriptan }(10 \mathrm{mg}) \text { or placebo nasal spray. The } \\
\text { second migraine was treated with the other medication }\end{array}$ \\
\hline \multirow[t]{3}{*}{ Outcomes } & $\begin{array}{l}\text { - Headache relief at } 2 \mathrm{~h} \text { (2-point decrease in headache intensity) } \\
\text { - Pain free at } 2 \mathrm{~h} \\
\text { - Presence of nausea and vomiting at } 2 \mathrm{~h} \\
\text { - Use of rescue medication with } 24 \mathrm{~h} \\
\text { - Adverse events }\end{array}$ \\
\hline & Other reported outcomes: \\
\hline & $\begin{array}{l}\text { - Headache relief, pain free, nausea, vomiting, photophobia, and phonophobia at } 15,30,60,90,180 \text {, } \\
\text { and } 240 \text { minutes }\end{array}$ \\
\hline Headache severity scale & 4-point scale (none, mild, moderate, severe) \\
\hline Funding source & GlaxoSmithKline \\
\hline Publication & Clinical trial registry \\
\hline Notes & - \\
\hline
\end{tabular}

\section{Risk of bias}

\begin{tabular}{|c|c|c|}
\hline Bias & Authors' judgement & Support for judgement \\
\hline \multirow{2}{*}{$\begin{array}{l}\text { Random sequence genera- } \\
\text { tion (selection bias) }\end{array}$} & Unclear risk & Quote: "randomized at visit one". \\
\hline & & $\begin{array}{l}\text { Comment: probably done as with previous studies by sponsor but not report- } \\
\text { ed }\end{array}$ \\
\hline $\begin{array}{l}\text { Allocation concealment } \\
\text { (selection bias) }\end{array}$ & Unclear risk & $\begin{array}{l}\text { Quote: "randomized at visit one and received a single dose of sumatriptan } 10 \\
\text { mg nasal spray or placebo to treat one migraine attack. At visit } 2 \text { they received } \\
\text { the alternate treatment..." }\end{array}$ \\
\hline $\begin{array}{l}\text { Blinding (performance } \\
\text { bias and detection bias) } \\
\text { All outcomes }\end{array}$ & Unclear risk & Comment: no information provided \\
\hline $\begin{array}{l}\text { Incomplete outcome data } \\
\text { (attrition bias) } \\
\text { All outcomes }\end{array}$ & Low risk & Comment: missing outcome data balanced across intervention groups \\
\hline $\begin{array}{l}\text { Selective reporting (re- } \\
\text { porting bias) }\end{array}$ & Low risk & Comment: all expected outcomes reported \\
\hline
\end{tabular}


Lewis 2002

\section{Study characteristics}

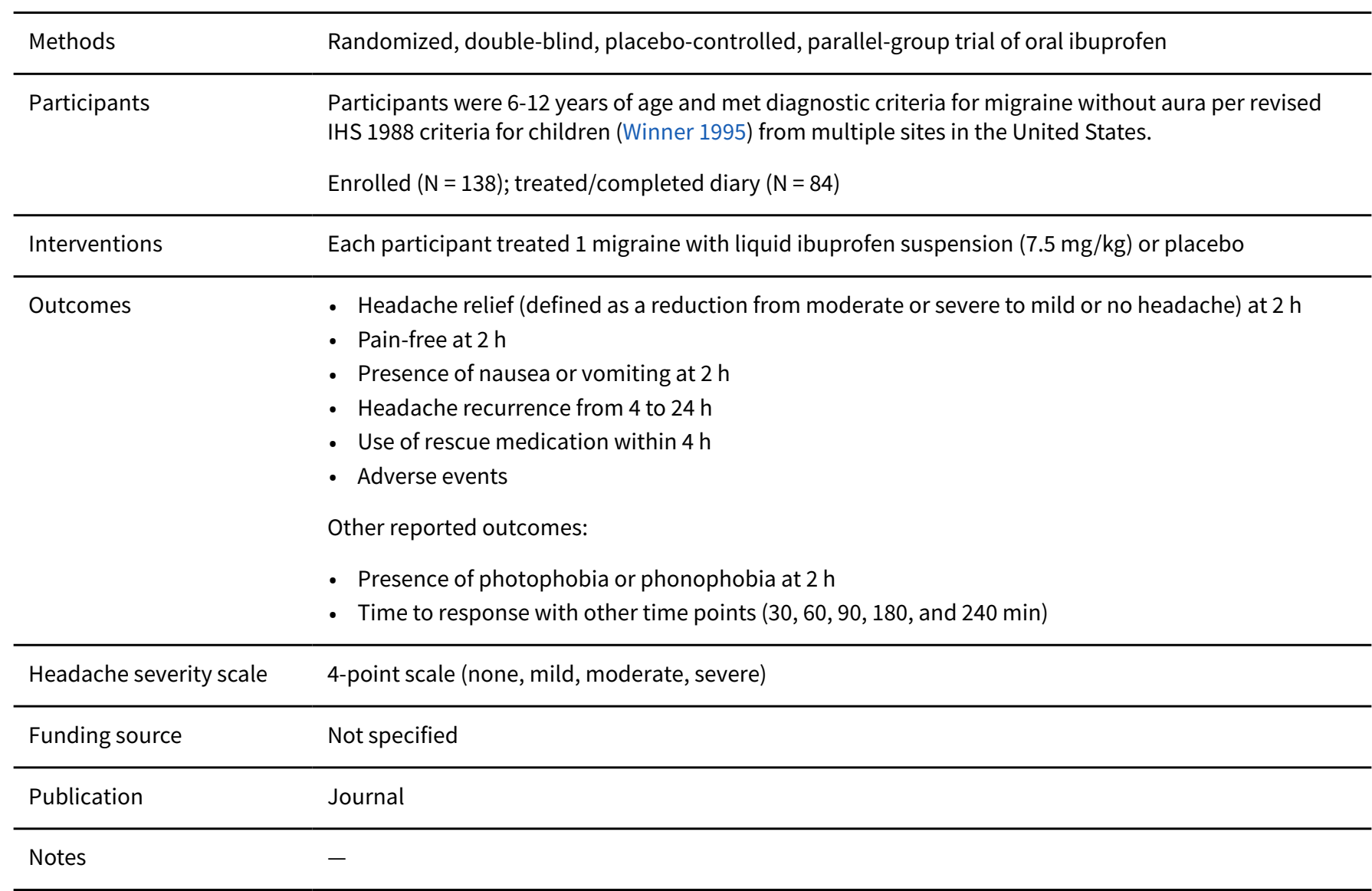

\section{Risk of bias}

\begin{tabular}{lll}
\hline Bias & Authors' judgement & Support for judgement \\
\hline $\begin{array}{l}\text { Random sequence genera- } \\
\text { tion (selection bias) }\end{array}$ & Unclear risk & $\begin{array}{l}\text { Quote: "Subjects were randomly assigned (stratified by gender) to the study } \\
\text { medication in a double-blind fashion." }\end{array}$ \\
\hline $\begin{array}{l}\text { Allocation concealment } \\
\text { (selection bias) }\end{array}$ & Unclear risk & $\begin{array}{l}\text { Quote: "Subjects were randomized to one of the following groups in a 1:1 ra- } \\
\text { tio" }\end{array}$ \\
\hline $\begin{array}{l}\text { Blinding (performance } \\
\text { bias and detection bias) } \\
\text { All outcomes }\end{array}$ & Low risk & Quote: "matching placebo suspension" \\
\hline $\begin{array}{l}\text { Incomplete outcome data } \\
\text { (attrition bias) } \\
\text { All outcomes }\end{array}$ & Low risk & Comment: no description of taste or color \\
\hline $\begin{array}{l}\text { Selective reporting (re- } \\
\text { porting bias) }\end{array}$ & Low risk & $\begin{array}{l}\text { Quote: "Fifty-four patients were randomized but were not evaluable... Six } \\
\text { treated with study agent" }\end{array}$ \\
\hline
\end{tabular}


Lewis 2007

\section{Study characteristics}

$\begin{array}{ll}\text { Methods } & \text { Multicenter, randomized, double-blind, placebo-controlled, 2-way, 2-attack, cross-over study of } \\ \text { zolmitriptan nasal spray with a single-blind 'placebo challenge' or 'enrichment' phase }\end{array}$

Participants
ria or revised IHS-1988 criteria (Winner 1995) with a frequency of 2 or more migraine attacks per month
during the school year and $<14$ days per month without migraine for the 3 months before screening.
The usual duration of untreated migraine was required to be $>2$ h. Participants were permitted to use
preventive medication that had been stable for 2 months before randomization.

Randomized ( $\mathrm{N}=248)$; withdrawn $(\mathrm{N}=34)$; placebo responder to both attacks $(\mathrm{N}=12)$; placebo responder to 1 attack $(N=12)$; missing efficiency data $(N=19)$; intention-to-treat analysis $(N=171)$

Interventions

Each participant treated 1 migraine attack with zolmitriptan $5 \mathrm{mg}$ nasal spray and another with matching placebo within a 12-week period. Each attack was treated initially with placebo normal saline within $30 \mathrm{~min}$ after the headache reached moderate or severe intensity. If migraine intensity remained moderate or severe, then participants were randomly assigned to use zolmitriptan or matching placebo (1:1). A second dose of randomized treatment or approved escape medications were permitted $2 \mathrm{~h}$ after the first dose if moderate or severe pain persisted.

Outcomes

- Headache relief (decrease from moderate or severe to mild or no headache) at $2 \mathrm{~h}$ ( $1 \mathrm{~h}$ was used as the primary outcome in the study)

- Pain-free at $2 \mathrm{~h}$

- Use of rescue medication

- Presence of nausea

- Use of rescue medications within $2 \mathrm{~h}$

- Adverse events

Other reported outcomes:

- Presence of photophobia and phonophobia

- Other time points including 15, 30, 45, 60, and $90 \mathrm{~min}$

\begin{tabular}{ll}
\hline Headache severity scale & 4-point scale (none, mild, moderate, severe) \\
\hline Funding source & AstraZeneca \\
\hline Publication & Journal and clinical trial registry \\
\hline Notes & -
\end{tabular}

\section{Risk of bias}

\begin{tabular}{lll}
\hline Bias & Authors' judgement & Support for judgement \\
\hline $\begin{array}{l}\text { Random sequence genera- } \\
\text { tion (selection bias) }\end{array}$ & Unclear risk & Quote: "Patients were randomly assigned strictly sequentially" \\
\hline $\begin{array}{l}\text { Allocation concealment } \\
\text { (selection bias) }\end{array}$ & Low risk & $\begin{array}{l}\text { Quote: "double-blind randomization schedule (prepared by the study spon- } \\
\text { sor)" }\end{array}$ \\
\hline $\begin{array}{l}\text { Blinding (performance } \\
\text { bias and detection bias) } \\
\text { All outcomes }\end{array}$ & Low risk & Quote: "matching placebo" \\
& $\begin{array}{l}\text { Comment: unique study design with placebo challenge where all subjects ini- } \\
\text { tially received placebo in a single-blind (participant) fashion. Only those who } \\
\text { did not respond were randomly assigned to active drug or placebo. }\end{array}$ \\
\hline
\end{tabular}


Lewis 2007 (Continued)

Incomplete outcome data Low risk Comment: missing outcome data distributed evenly across intervention (attrition bias)

All outcomes

\section{groups}

Selective reporting (re- Low risk Comment: all expected outcomes reported porting bias)

\section{Linder 2008}

\section{Study characteristics}

\begin{tabular}{|c|c|}
\hline Methods & Randomized, double-blind, placebo-controlled, parallel-group multicenter trial of oral almotriptan \\
\hline Participants & $\begin{array}{l}\text { Participants from the United States ( } 81 \text { sites), Argentina ( } 6 \text { sites), Colombia ( } 3 \text { sites), and Mexico ( } 3 \text { sites) } \\
\text { diagnosed with migraine were aged } 12-17 \text { years (block randomization in } 2 \text { groups: } 12-14 \text { years and } \\
15-17 \text { years). The participants were required to have a }>1 \text {-year history of migraine with or without au- } \\
\text { ra per the IHS } 1988 \text { criteria and a frequency of } 1-6 \text { moderate or severe attacks per month, lasting }>4 \mathrm{~h} \\
\text { without treatment and occurring at intervals of }>24 \mathrm{~h} \text { for the } 2 \text { months prior to screening. Following a } \\
\text { 30-day run-in period to document migraine severity and frequency, eligible participants were random- } \\
\text { ized 1:1:1:1 within the } 2 \text { age groups to treat } 1 \text { attack. }\end{array}$ \\
\hline & $\begin{array}{l}\text { Enrolled }(N=866) \text {; did not receive medication }(N=146) \text {; non-compliant }(N=6) \text {; safety analysis }(N=720) \text {; } \\
\text { primary efficacy analysis }(N=714)\end{array}$ \\
\hline
\end{tabular}

Interventions

Each participant treated 1 attack with either oral almotriptan $(6.25 \mathrm{mg}, 12.5 \mathrm{mg}$, or $25 \mathrm{mg}$ ) or placebo as soon as possible within $4 \mathrm{~h}$ after the onset of moderate to severe pain.

\begin{tabular}{|c|c|}
\hline Outcomes & $\begin{array}{l}\text { - Headache relief at } 2 \mathrm{~h} \text { (a decrease from moderate or severe pain intensity to mild or no pain) } \\
\text { - Pain-free at } 2 \mathrm{~h} \\
\text { - Presence of nausea at } 2 \mathrm{~h} \\
\text { - Use of rescue medication within } 2-24 \mathrm{~h} \\
\text { - Headache recurrence within } 2-24 \mathrm{~h} \\
\text { - Adverse events } \\
\text { Other reported outcomes: } \\
\text { - Other time points }(0.25,0.5,1,1.5 \mathrm{~h}) \\
\text { - Presense of photophobia or phonophobia at } 2 \mathrm{~h} \\
\text { - Sustained pain relief } \\
\text { - Sustained pain-free }\end{array}$ \\
\hline Headache severity scale & 4-point scale (none, mild, moderate, severe) \\
\hline Funding source & Janssen-Ortho LLC: Ortho-McNeil Neurologics, Inc. \\
\hline Publication & Journal and clinical trial registry \\
\hline Notes & - \\
\hline Risk of bias & \\
\hline Bias & Authors' judgement Support for judgement \\
\hline $\begin{array}{l}\text { Random sequence genera- } \\
\text { tion (selection bias) }\end{array}$ & Quote: "randomized 1:1:1:1 within 2 age groups" \\
\hline
\end{tabular}


Linder 2008 (Continued)

$\begin{array}{ll}\begin{array}{l}\text { Allocation concealment } \\ \text { (selection bias) }\end{array} & \text { Unclear risk }\end{array} \quad \begin{aligned} & \text { Comment: each participant received } 2 \text { tablets of either study medication or } \\ & \text { placebo }\end{aligned}$
(selection bias)

Unclear risk

Comment: described as 'double-blind'. Previous studies by sponsor included

Blinding (performance acceptable blinding methods (e.g. Lewis 2007).

All outcomes

Incomplete outcome data Low risk

Comment: missing outcome data balanced across intervention groups

(attrition bias)

All outcomes

Selective reporting (re- Low risk Comment: all expected outcomes reported porting bias)

NCT01211145

\section{Study characteristics}

\begin{tabular}{|c|c|}
\hline Methods & Randomized, double-blind, placebo-controlled, parallel group trial of zolmitriptan nasal spray \\
\hline Participants & $\begin{array}{l}\text { Participants from } 74 \text { study sites worldwide were adolescents } 12-17 \text { years of age, diagnosed with mi- } \\
\text { graine per IHS } 1988 \text { or revised IHS criteria (Winner } 1995) \text { and a history of at least } 2 \text { migraine attacks per } \\
\text { month. Lack of response to single-blind placebo run-in period was also required. } \\
\text { Randomized }(N=798) \text {; did not receive study drug }(N=141) \text {; analyzed }(N=584)\end{array}$ \\
\hline Interventions & Zolmitriptan 0.5, 2.5, $5 \mathrm{mg}$ nasal spray \\
\hline Outcomes & $\begin{array}{l}\text { - Pain-free at } 2 \mathrm{~h} \\
\text { - Headache relief (defined as decreased from severe or moderate to mild or none) at } 2 \mathrm{~h} \\
\text { - Use of rescue medication during the first } 24 \mathrm{~h} \\
\text { - Presense of nausea or vomiting at } 2 \mathrm{~h} \\
\text { Other reported outcomes: } \\
\text { - Presence of photophobia, phonophobia, nausea, or vomiting at } 0.25,1,3,4 \text {, and } 24 \mathrm{~h} \\
\text { - Headache relief (defined as decreased from severe or moderate to mild or none and no use of rescue } \\
\text { medication) at } 0.25,1,3,4 \text {, and } 24 \mathrm{~h} \\
\text { - Pain-free at } 0.25,1,3,4 \text {, and } 24 \mathrm{~h}\end{array}$ \\
\hline Headache severity scale & 4-point scale (none, mild, moderate, severe) \\
\hline Funding source & AstraZeneca \\
\hline Publication & Clinical trial registry \\
\hline Notes & $\begin{array}{l}\text { At the interim futility analysis, the zolmitriptan } 0.5 \text { and } 2.5 \mathrm{mg} \text { groups were declared futile, allocation } \\
\text { discontinued, and not included in the efficacy analysis }\end{array}$ \\
\hline
\end{tabular}

\section{Risk of bias}

\section{Bias}

Random sequence genera- Unclear risk tion (selection bias)

\section{Authors' judgement Support for judgement}

Quote: "were randomized into the study to obtain 800 evaluable patients" 
NCT01211145 (Continued)

Comment: no description of randomization procedures provided

\begin{tabular}{|c|c|c|}
\hline $\begin{array}{l}\text { Allocation concealment } \\
\text { (selection bias) }\end{array}$ & Unclear risk & Comment: no information provided \\
\hline $\begin{array}{l}\text { Blinding (performance } \\
\text { bias and detection bias) } \\
\text { All outcomes }\end{array}$ & Unclear risk & Comment: study is described as blinded but no information provided \\
\hline $\begin{array}{l}\text { Incomplete outcome data } \\
\text { (attrition bias) } \\
\text { All outcomes }\end{array}$ & Low risk & $\begin{array}{l}\text { Quote: "Of the } 798 \text { patients, } 82.3 \% \text { ( } 657 / 798 \text { patients) received study drug, } \\
90.4 \% \text { ( } 721 / 798 \text { patients) completed the study and } 9.5 \% \text { ( } 76 / 798 \text { patients) dis- } \\
\text { continued from the study. . All patients received their assigned treatment. .. } \\
\text { Overall, the most common reason for study discontinuation was eligibility } \\
\text { criteria not fulfilled ( } 6.6 \%, 53 / 798 \text { patients). No patients discontinued due to } \\
\text { AEs." }\end{array}$ \\
\hline
\end{tabular}

Selective reporting (re- $\quad$ Unclear risk $\quad$ Comment: a clinical study report synopsis was reported with limited data
porting bias)
porting bias)

Rothner 1997

\section{Study characteristics}

\begin{tabular}{|c|c|}
\hline Methods & Randomized, double-blind, placebo-controlled, parallel trial of oral naratriptan \\
\hline \multirow[t]{2}{*}{ Participants } & $\begin{array}{l}\text { Participants were from the United States ( } 44 \text { sites), aged } 12-17 \text { years with a 1-year history of migraine } \\
\text { with or without aura as per the IHS } 1988 \text { criteria and had 1-8 migraine attacks per month of moderate } \\
\text { to severe intensity during the } 2 \text { months preceding the screening visit. }\end{array}$ \\
\hline & Randomized $(\mathrm{N}=350)$; withdrawn $(\mathrm{N}=51)$; intention-to-treat and primary efficacy analysis $(\mathrm{N}=300)$ \\
\hline Interventions & $\begin{array}{l}\text { Each participant treated } 1 \text { migraine with oral naratriptan }(0.25 \mathrm{mg}, 1.0 \mathrm{mg} \text {, or } 2.5 \mathrm{mg}) \text { or placebo. } \\
\text { A second, identical dose was available (optional) for participants who experienced recurrence. }\end{array}$ \\
\hline \multirow[t]{15}{*}{ Outcomes } & $\begin{array}{l}\text { - Headache relief at } 2 \mathrm{~h} \text { (reduction in pain severity from moderate or severe to none or mild); study } \\
\text { primary outcome was at } 4 \mathrm{~h}\end{array}$ \\
\hline & - Pain-free at $2 \mathrm{~h}$ \\
\hline & - Use of rescue medication within $24 \mathrm{~h}$ \\
\hline & - Presence of nausea at $2 \mathrm{~h}$ \\
\hline & - Headache recurrence \\
\hline & - Adverse events \\
\hline & Other reported outcomes: \\
\hline & - Headache relief at $15,30,45,60,90$, and 180 minutes \\
\hline & - Pain-free at $15,30,45,60,90,180$, and 240 minutes \\
\hline & - Presence of nausea, photophobia, phonophobia at $15,30,45,60,90,180$, and 240 minutes \\
\hline & - Sum of pain intensity scores \\
\hline & - Sustained headache relief within $4-24 \mathrm{~h}$ \\
\hline & - Clinical disability at $15,30,45,60,90,120,180$, and 240 minutes \\
\hline & - Sum of clinical disability intensity differences \\
\hline & - Incidence of and time to meaningful relief within 240 minutes \\
\hline Headache severity scale & 4-point scale (none, mild, moderate, severe) \\
\hline
\end{tabular}


Rothner 1997 (Continued)

\begin{tabular}{|c|c|c|}
\hline Funding source & \multicolumn{2}{|l|}{ GlaxoSmithKline } \\
\hline Publication & \multicolumn{2}{|c|}{ Abstract and clinical trial registry } \\
\hline Notes & - & \\
\hline \multicolumn{3}{|l|}{ Risk of bias } \\
\hline Bias & Authors' judgement & Support for judgement \\
\hline $\begin{array}{l}\text { Random sequence genera- } \\
\text { tion (selection bias) }\end{array}$ & Unclear risk & Quote: "Subjects were randomized (1:1:1:1)" \\
\hline $\begin{array}{l}\text { Allocation concealment } \\
\text { (selection bias) }\end{array}$ & Unclear risk & Comment: no information provided \\
\hline $\begin{array}{l}\text { Blinding (performance } \\
\text { bias and detection bias) } \\
\text { All outcomes }\end{array}$ & Unclear risk & $\begin{array}{l}\text { Comment: described as double-blind and previous studies by sponsor had ac- } \\
\text { ceptable blinding }\end{array}$ \\
\hline $\begin{array}{l}\text { Incomplete outcome data } \\
\text { (attrition bias) } \\
\text { All outcomes }\end{array}$ & Low risk & Comment: missing outcome data balanced across intervention groups \\
\hline $\begin{array}{l}\text { Selective reporting (re- } \\
\text { porting bias) }\end{array}$ & Low risk & Comment: all expected outcomes reported \\
\hline
\end{tabular}

Rothner 1999a

\section{Study characteristics}

Methods Randomized, double-blind, placebo-controlled, parallel-group 3-attack trial of oral sumatriptan

Participants Participants from 62 centers in 7 countries were 12 -17 years of age with a minimum 6-month history of migraine with or without aura per IHS 1988 criteria and 1-6 attacks per month

Randomized ( $N=347)$; withdrawn ( $N=117)$; intention-to-treat and primary efficacy analysis $(\mathrm{N}=273)$

Interventions $\quad$ Each participant treated 1 migraine with oral sumatriptan $25 \mathrm{mg}, 50 \mathrm{mg}, 100 \mathrm{mg}$, or placebo. No maximum time after the onset of migraine was specified.

\begin{tabular}{ll} 
- Headache relief at $2 \mathrm{~h}$ (moderate or severe pain intensity reduced to no or mild pain) \\
- Pain free at $2 \mathrm{~h}$ \\
- Presence of nausea within $4 \mathrm{~h}$ \\
- Use of rescue medication within $24 \mathrm{~h}$ \\
- Recurrence of migraine within $4-24 \mathrm{~h}$ \\
Other reported outcomes: \\
- Presense of photophobia or phonophobia within $4 \mathrm{~h}$ \\
- Other time points (headache relief at $1 \mathrm{~h}$ was primary outcome in study) \\
- Time to meaningful relief \\
\hline Headache severity scale & 4-point scale (none, mild, moderate, severe) \\
\hline \hline
\end{tabular}

Drugs for the acute treatment of migraine in children and adolescents (Review) 
Rothner 1999a (Continued)

\begin{tabular}{ll} 
Funding source & GlaxoSmithKline \\
\hline Publication & Abstract and clinical trial registry \\
\hline Notes & $\begin{array}{l}\text { Headache alleviation: reduction in headache from grade } 3 \text { or } 2 \text { to grade } 1 \text { or } 0 \text { within } 2 \mathrm{~h} \text { where } 3= \\
\text { headache, I can't do anything; } 2=\text { headache, I can do easy activities; } 1=\text { headache, I can carry on as } \\
\text { usual; and } 0=\text { no headache. } \\
\text { Funding: not stated }\end{array}$ \\
\hline
\end{tabular}

\section{Risk of bias}

\begin{tabular}{lll}
\hline Bias & Authors' judgement & Support for judgement \\
\hline $\begin{array}{l}\text { Random sequence genera- } \\
\text { tion (selection bias) }\end{array}$ & Unclear risk & Comment: described as randomized but no details \\
\hline $\begin{array}{l}\text { Allocation concealment } \\
\text { (selection bias) }\end{array}$ & Unclear risk & Comment: no description of allocation concealment \\
\hline $\begin{array}{l}\text { Blinding (performance } \\
\text { bias and detection bias) } \\
\text { All outcomes }\end{array}$ & Unclear risk & Comment: no description of efforts to maintain blinding \\
\hline $\begin{array}{l}\text { Incomplete outcome data } \\
\text { (attrition bias) } \\
\text { All outcomes }\end{array}$ & Low risk & Comment: missing outcome data balanced across intervention groups \\
\hline $\begin{array}{l}\text { Selective reporting (re- } \\
\text { porting bias) }\end{array}$ & Low risk & Comment: all expected outcomes reported \\
\hline
\end{tabular}

Rothner 1999b

\section{Study characteristics}

\begin{tabular}{|c|c|}
\hline Methods & Randomized, double-blind, placebo-controlled, parallel-group trial of oral sumatriptan \\
\hline \multirow[t]{2}{*}{ Participants } & $\begin{array}{l}\text { Participants from Canada ( } 14 \text { sites) were aged } 12-17 \text { years, had a } 3 \text {-month history of migraine with or } \\
\text { without aura as per the IHS } 1988 \text { criteria (except headaches could be }<2 \mathrm{~h} \text { ) and the migraine attack had } \\
\text { lasted }<24 \mathrm{~h} \text {. }\end{array}$ \\
\hline & Randomized ( $N=119)$; withdrawn $(N=27)$; intention-to-treat and primary efficacy analysis $(N=92)$ \\
\hline Interventions & $\begin{array}{l}\text { Each participant treated } 1 \text { migraine with oral sumatriptan ( } 50 \mathrm{mg} \text { for body weight } 30-50 \mathrm{~kg} ; 100 \mathrm{mg} \text { for } \\
\text { body weight }>50 \mathrm{~kg} \text { ) or placebo. Use of rescue medication was permitted after } 4 \mathrm{~h} \text { of study treatment. }\end{array}$ \\
\hline \multirow[t]{4}{*}{ Outcomes } & $\begin{array}{l}\text { - Headache relief at } 2 \mathrm{~h} \text { (2-grade decrease in headache disability) } \\
\text { - Pain free at } 2 \mathrm{~h} \\
\text { - Presence of nausea } \\
\text { - Use of rescue medication after } 4 \mathrm{~h} \\
\text { - Headache recurrence within } 24 \mathrm{~h} \\
\text { - Adverse events }\end{array}$ \\
\hline & Other reported outcomes: \\
\hline & - $4 \mathrm{~h}$ time point \\
\hline & - Presense of photophobia or phonophobia \\
\hline
\end{tabular}


Rothner 1999b (Continued)

- Clinical disability

- Time to start of headache improvement

- Time to return to normal activities

- Time until completely back to normal

\begin{tabular}{ll}
\hline Headache severity scale & 4-point scale (none, mild, moderate, severe) \\
\hline Funding source & GlaxoSmithKline \\
\hline Publication & Abstract and clinical trial registry \\
\hline Notes & - \\
\hline
\end{tabular}

\section{Risk of bias}

\begin{tabular}{|c|c|c|}
\hline Bias & Authors' judgement & Support for judgement \\
\hline $\begin{array}{l}\text { Random sequence genera- } \\
\text { tion (selection bias) }\end{array}$ & Unclear risk & Quote: "Subjects were randomized (1:1:1 ratio) to receive..." \\
\hline $\begin{array}{l}\text { Allocation concealment } \\
\text { (selection bias) }\end{array}$ & Unclear risk & Comment: no information provided \\
\hline $\begin{array}{l}\text { Blinding (performance } \\
\text { bias and detection bias) } \\
\text { All outcomes }\end{array}$ & Unclear risk & Comment: described as "placebo-controlled"; participant-reported outcomes \\
\hline $\begin{array}{l}\text { Incomplete outcome data } \\
\text { (attrition bias) } \\
\text { All outcomes }\end{array}$ & Low risk & Comment: missing outcome data balanced across intervention groups. \\
\hline $\begin{array}{l}\text { Selective reporting (re- } \\
\text { porting bias) }\end{array}$ & Low risk & Comment: all expected outcomes reported \\
\hline
\end{tabular}

Rothner 1999c

\section{Study characteristics}

Methods Randomized, double-blind, placebo-controlled, parallel-group trial of oral sumatriptan

\section{Participants}

Participants were from 18 centers in 8 countries and 12-17 years of age with migraine with or without aura per IHS 1988 criteria; treated 1 attack following a run-in period of up to 8 weeks during which their usual medication was used to treat 1 migraine attack

Randomized ( $\mathrm{N}=139)$; withdrawn $(\mathrm{N}=37)$; intention-to-treat and primary efficacy analysis $(\mathrm{N}=102)$

\begin{tabular}{ll}
\hline Interventions & Oral sumatriptan $50 \mathrm{mg}$ ( 30 to $50 \mathrm{~kg}$ ) or sumatriptan $100 \mathrm{mg}$ (>50 kg) versus placebo \\
\hline Outcomes & - Headache/disability relief (grade $2 / 3$ to $0 / 1$ ) at $2 \mathrm{~h}$ \\
- Pain free at $2 \mathrm{~h}$ \\
- Presence of nausea \\
- Use of rescue medication after $4 \mathrm{~h}$ \\
- Hdverse events
\end{tabular}


Rothner 1999c (Continued)

Other reported outcomes:

- $4 \mathrm{~h}$ time point

- Presense of photophobia or phonophobia

- Time to headache improvement

- Time to disappearance of headache

- Time to resumption of normal activities

- Time to feeling 'completely back to normal'

- Global response to study medication

Headache severity scale

Headache/clinical disability score (grade 3 = headache - "I can't do anything"; grade 2 = headache - "I can do easy activities"; grade $1=$ headache - "I can carry on as usual", grade $0=$ no headache)

\begin{tabular}{|c|c|c|}
\hline Funding source & \multicolumn{2}{|l|}{ GlaxoSmithKline } \\
\hline Publication & \multicolumn{2}{|c|}{ Abstract and clinical trial registry } \\
\hline Notes & - & \\
\hline \multicolumn{3}{|l|}{ Risk of bias } \\
\hline Bias & Authors' judgement & Support for judgement \\
\hline $\begin{array}{l}\text { Random sequence genera- } \\
\text { tion (selection bias) }\end{array}$ & Unclear risk & Comment: described as "randomized in a 1:1:1 ratio..." \\
\hline $\begin{array}{l}\text { Allocation concealment } \\
\text { (selection bias) }\end{array}$ & Unclear risk & Comment: no description of methods to maintain allocation concealment \\
\hline $\begin{array}{l}\text { Blinding (performance } \\
\text { bias and detection bias) } \\
\text { All outcomes }\end{array}$ & Unclear risk & $\begin{array}{l}\text { Comment: described as "double-blind"; previous studies by sponsor had ade- } \\
\text { quate blinding procedures }\end{array}$ \\
\hline $\begin{array}{l}\text { Incomplete outcome data } \\
\text { (attrition bias) } \\
\text { All outcomes }\end{array}$ & Low risk & Comment: withdrawals balances between intervention groups \\
\hline $\begin{array}{l}\text { Selective reporting (re- } \\
\text { porting bias) }\end{array}$ & Unclear risk & $\begin{array}{l}\text { Comment: outcomes extensively reported in the GlaxoSmithKline clinical trial } \\
\text { registry }\end{array}$ \\
\hline
\end{tabular}

Rothner 2006

\section{Study characteristics}

\begin{tabular}{|c|c|}
\hline Methods & Randomized, double-blind, placebo-controlled, parallel-group trial of oral zolmitriptan \\
\hline \multirow[t]{2}{*}{ Participants } & $\begin{array}{l}\text { Participants were from the United States ( } 40 \text { sites), Canada ( } 10 \text { sites), India ( } 23 \text { sites), Finland, Germany, } \\
\text { and the United Kingdom. Eligible participants were aged } 12-17 \text { years with a diagnosis of migraine with } \\
\text { or without aura per the IHS } 1988 \text { criteria and were required to have } 2-10 \text { migraine or non-migraine } \\
\text { headaches per month lasting longer than } 4 \mathrm{~h} \text { without treatment in the last } 3 \text { months preceding screen- } \\
\text { ing }\end{array}$ \\
\hline & $\begin{array}{l}\text { Randomized }(N=850) \text {; did not treat at least } 1 \text { attack }(N=151) \text {; intention-to-treat and primary efficacy } \\
\text { analysis }(N=696)\end{array}$ \\
\hline
\end{tabular}


Rothner 2006 (Continued)

Interventions Each participant treated 1 migraine attack with oral zolmitriptan ( $2.5 \mathrm{mg}, 5 \mathrm{mg}$, or $10 \mathrm{mg})$ or placebo no later than $1 \mathrm{~h}$ after the onset of moderate or severe headache, more than $24 \mathrm{~h}$ had elapsed since the last migraine attack and the migraine attack occurred within 12 weeks of randomization. Participants were allowed to take an approved escape medication 2 or more $\mathrm{h}$ after study treatment.

$\begin{array}{ll}\text { Outcomes } & \text { Headache relief at } 2 \mathrm{~h} \text { (pain decrease from moderate or severe to mild or none) } \\ \text { - Pain free } & \text { Adverse events } \\ \text { Other reported outcomes: } \\ \text { - Other time points including } 30 \text { and } 60 \mathrm{~min}\end{array}$

Headache severity scale 4-point scale (none, mild, moderate, severe)

\begin{tabular}{ll}
\hline Funding source & AstraZeneca \\
\hline Publication & Journal and clinical trial registry \\
\hline Notes & - \\
\hline
\end{tabular}

\section{Risk of bias}

\begin{tabular}{|c|c|c|}
\hline Bias & Authors' judgement & Support for judgement \\
\hline $\begin{array}{l}\text { Random sequence genera- } \\
\text { tion (selection bias) }\end{array}$ & Unclear risk & Quote: "numbers allocated sequentially as patients entered the study" \\
\hline $\begin{array}{l}\text { Allocation concealment } \\
\text { (selection bias) }\end{array}$ & Unclear risk & $\begin{array}{l}\text { Quote: "The randomization schedule was produced by the Biometrics Group of } \\
\text { AstraZeneca." }\end{array}$ \\
\hline $\begin{array}{l}\text { Blinding (performance } \\
\text { bias and detection bias) } \\
\text { All outcomes }\end{array}$ & Low risk & Quote: "three tablets, all of which were identical in appearance" \\
\hline $\begin{array}{l}\text { Incomplete outcome data } \\
\text { (attrition bias) } \\
\text { All outcomes }\end{array}$ & Low risk & Comment: missing outcome data balanced across intervention groups \\
\hline $\begin{array}{l}\text { Selective reporting (re- } \\
\text { porting bias) }\end{array}$ & Low risk & Comment: all expected outcomes reported \\
\hline
\end{tabular}

Ueberall 1999

\section{Study characteristics}

\begin{tabular}{ll}
\hline Methods & Randomized, double-blind, placebo-controlled, 2 -way cross-over trial of intranasal sumatriptan \\
\hline Participants & $\begin{array}{l}\text { Participants were }<10 \text { years of age with migraine with or without aura per IHS } 1988 \text { criteria and at leas } \\
2 \text { migraine attacks per month } \\
\text { Randomized }(\mathrm{N}=14) \text {; analyzed }(\mathrm{N}=14)\end{array}$ \\
\hline Interventions & $\begin{array}{l}\text { Each participant treated } 1 \text { migraine with intranasal sumatriptan }(20 \mathrm{mg}) \text { or placebo. The second mi- } \\
\text { graine was treated with the other medication. }\end{array}$
\end{tabular}


Ueberall 1999 (Continued)

\begin{tabular}{|c|c|}
\hline Outcomes & $\begin{array}{l}\text { - Headache relief at } 2 \mathrm{~h} \\
\text { - Pain free at } 2 \mathrm{~h} \\
\text { - Headache recurrence } \\
\text { - Use of rescue medication } \\
\text { - Presence of nausea or vomiting within } 4 \mathrm{~h} \\
\text { - } \text { Adverse events } \\
\text { Other reported outcomes: } \\
\text { - Presense of photophobia or phonophobia within } 4 \mathrm{~h} \\
\text { - Other time points ( } 30,60,180,240 \text { minutes) } \\
\text { - Time to meaningful recovery } \\
\text { - Treatment preference }\end{array}$ \\
\hline Headache severity scale & 4-point scale (none, mild, moderate, severe) \\
\hline Funding source & Not specified \\
\hline Publication & Journal \\
\hline Notes & - \\
\hline
\end{tabular}

\section{Risk of bias}

\begin{tabular}{lll}
\hline Bias & Authors' judgement & Support for judgement \\
\hline $\begin{array}{l}\text { Random sequence genera- } \\
\text { tion (selection bias) }\end{array}$ & Low risk & Quote: "Randomization was based on a computer algorithm..." \\
\hline $\begin{array}{l}\text { Allocation concealment } \\
\text { (selection bias) }\end{array}$ & Unclear risk & $\begin{array}{l}\text { Quote: "Patients were randomly assigned to two alternative treatment strata"; } \\
\text { "access to treatment assignments were given to D.W., if necessary" }\end{array}$ \\
\hline $\begin{array}{l}\text { Blinding (performance } \\
\text { bias and detection bias) } \\
\text { All outcomes }\end{array}$ & Unclear risk & Quote: "0.9\% sodium chloride" used as placebo \\
\hline $\begin{array}{l}\text { Incomplete outcome data } \\
\text { (attrition bias) } \\
\text { All outcomes }\end{array}$ & Low risk & $\begin{array}{l}\text { Comment: cross-over trial; blinding likely maintained. Disturbance of taste re- } \\
\text { ported both for sumatriptan and placebo }\end{array}$ \\
\hline $\begin{array}{l}\text { Selective reporting (re- } \\
\text { porting bias) }\end{array}$ & Low risk & Quote: "Data sufficient for analysis were provided by all 14 children". \\
\hline
\end{tabular}

\section{Visser 2004a}

\section{Study characteristics}

\begin{tabular}{ll}
\hline Methods & Randomized, double-blind, placebo-controlled, parallel-group single-attack trial of oral rizatriptan \\
\hline Participants & $\begin{array}{l}\text { Participants from } 44 \text { centers in the United States } 12-17 \text { years of age with a } 1 \text { year history of migraine } \\
\text { with or without aura per IHS } 1988 \text { criteria and } 1-8 \text { attacks per month. Randomization was stratified by } \\
\text { age }(12-14 \text { and } 15-17 \text { years). } \\
\text { Randomized ( } N=686) \text {; did not take study medication }(\mathrm{N}=210) \text {; primary efficacy analysis }(\mathrm{N}=476)\end{array}$ \\
\hline \hline
\end{tabular}


Visser 2004a (Continued)

Interventions
Each participant treated 1 migraine with oral rizatriptan $(5 \mathrm{mg})$ or placebo within 30 minutes of onset. Up to 2 recurrences could be treated with the same medication. Participants could only treat migraine attacks on days they were not in school or at camp.

\begin{tabular}{|c|c|}
\hline Outcomes & $\begin{array}{l}\text { - Headache relief at } 2 \mathrm{~h} \text { (reduction from moderate or severe to mild or none) } \\
\text { - Pain free at } 2 \mathrm{~h} \\
\text { - Headache recurrence within } 24 \mathrm{~h} \\
\text { - Presence of nausea or vomiting } \\
\text { - Adverse events } \\
\text { Other reported outcomes: } \\
\text { - Presense of photophobia or phonophobia } \\
\text { - Other time points }(0.5,1,1.5,3 \text {, and } 4 \mathrm{~h}), \\
\text { - Functional ability } \\
\text { - Headache severity }\end{array}$ \\
\hline Headache severity scale & 4-level (none, mild, moderate, severe) \\
\hline Funding source & Merck \\
\hline Publication & Journal \\
\hline
\end{tabular}

\section{Risk of bias}

\begin{tabular}{lll}
\hline Bias & Authors' judgement & Support for judgement \\
\hline $\begin{array}{l}\text { Random sequence genera- } \\
\text { tion (selection bias) }\end{array}$ & Unclear risk & Comment: no information provided \\
\hline $\begin{array}{l}\text { Allocation concealment } \\
\text { (selection bias) }\end{array}$ & Unclear risk & Comment: no information provided \\
\hline $\begin{array}{l}\text { Blinding (performance } \\
\text { bias and detection bias) } \\
\text { All outcomes }\end{array}$ & Unclear risk & Comment: described as double-blind \\
\hline $\begin{array}{l}\text { Incomplete outcome data } \\
\text { (attrition bias) }\end{array}$ & Low risk & $\begin{array}{l}\text { Quote: "The number of patients who discontinued prior to taking study med- } \\
\text { ication and the distribution of reasons for the lack of treatment were compara- } \\
\text { ble across the treatment arms." }\end{array}$ \\
\hline $\begin{array}{l}\text { Selective reporting (re- } \\
\text { porting bias) }\end{array}$ & Low risk & Comment: all expected outcomes reported \\
\hline
\end{tabular}

Winner 1997

\section{Study characteristics}

\begin{tabular}{ll}
\hline Methods & $\begin{array}{l}\text { Randomized, double-blind, placebo-controlled, 4-period, outpatient, cross-over, 4-attack study of oral } \\
\text { sumatriptan }\end{array}$ \\
\hline Participants & $\begin{array}{l}\text { Participants were } 12-17 \text { yrs with }>6 \text { month history of migraine with or without aura as defined by IHS } \\
\text { 1988; had 1-8 moderate or severe migraine attacks monthly during the } 2 \text { months prior to screening }\end{array}$ \\
\hline
\end{tabular}


Winner 1997 (Continued)

Randomized ( $\mathrm{N}=355)$; withdrawn ( $\mathrm{N}=194)$; intention-to-treat and primary efficacy analysis $(\mathrm{N}=298)$

Interventions Each participant treated up to 4 migraine attacks of moderate or severe intensity in a cross-over fashion; 1 attack with placebo and 3 with sumatriptan $25 \mathrm{mg}, 50 \mathrm{mg}$, or $100 \mathrm{mg}$ (same dose for all 3 attacks). Participants were randomized in a balanced fashion to 1-12 treatment sequences.
- Headache relief (reduction in severity from moderate or severe to none or mild) at $2 \mathrm{~h}$ after the first dose of study drug for the first attack and across attacks were the primary outcome measures; data from treatment of the first migraine attack are used in the systematic review

- Pain-free at $2 \mathrm{~h}$

- Presense of nausea or vomiting at $2 \mathrm{~h}$

- Use of rescue medication

- Adverse events

Other reported outcomes:

- Time to meaningful relief (within $4 \mathrm{~h}$ )

- Presense of photophobia or phonophobia

- Clinical disability

- Other time points $(15,30,45,60,90,180$, and $240 \mathrm{~min})$

\begin{tabular}{ll}
\hline Headache severity scale & 4-level (none, mild, moderate, severe) \\
\hline Funding source & GlaxoSmithKline \\
\hline Publication & Journal and clinical trial registry \\
\hline Notes & - \\
\hline
\end{tabular}

\section{Risk of bias}

\begin{tabular}{|c|c|c|}
\hline Bias & Authors' judgement & Support for judgement \\
\hline $\begin{array}{l}\text { Random sequence genera- } \\
\text { tion (selection bias) }\end{array}$ & Unclear risk & $\begin{array}{l}\text { Comment: described as "randomized in a balanced manner to } 1 \text { of } 12 \text { treat- } \\
\text { ment sequences" }\end{array}$ \\
\hline $\begin{array}{l}\text { Allocation concealment } \\
\text { (selection bias) }\end{array}$ & Unclear risk & $\begin{array}{l}\text { Comment: methods to maintain allocation concealment were not described; } \\
\text { previous studies by sponsor had adequate allocation concealment }\end{array}$ \\
\hline $\begin{array}{l}\text { Blinding (performance } \\
\text { bias and detection bias) } \\
\text { All outcomes }\end{array}$ & Unclear risk & $\begin{array}{l}\text { Comment: described as "double-blind, placebo-controlled"; methods to main- } \\
\text { tain blinding were not reported }\end{array}$ \\
\hline $\begin{array}{l}\text { Incomplete outcome data } \\
\text { (attrition bias) } \\
\text { All outcomes }\end{array}$ & Low risk & $\begin{array}{l}\text { Comment: a total of } 194 \text { subjects withdrew, but were balanced across inter- } \\
\text { vention groups }\end{array}$ \\
\hline $\begin{array}{l}\text { Selective reporting (re- } \\
\text { porting bias) }\end{array}$ & Low risk & Comment: all expected outcomes reported \\
\hline
\end{tabular}

\section{Study characteristics}


Winner 2000 (Continued)

Methods

Randomized, double-blind, placebo-controlled, single-attack, parallel-group study of intranasal sumatriptan

Participants

Males and females 12-17 years of age with a diagnosis of migraine (with or without aura) meeting IHS 1988 criteria and typical duration $>4 \mathrm{~h}$ and with at least a 6-month history of 2-8 moderate or severe migraine attacks per month for each of the 2 months preceding study enrolment. Participants were required to have $<15$ days of tension headache per month and were required to have failed at least 1 previous over-the-counter or prescription medication for the treatment of migraine.

Randomized ( $N=653)$; withdrawn $(\mathrm{N}=147)$; missing efficacy data $(\mathrm{N}=3)$; intention-to-treat analysis $(\mathrm{N}$ $=510)$; primary efficacy analysis $(\mathrm{N}=507)$

Interventions Each participant treated 1 migraine with nasal sumatriptan $(5,10$, or $20 \mathrm{mg})$ or placebo. A second dose of the same nasal spray could be used 2-24 $\mathrm{h}$ after the initial dose.

\begin{tabular}{ll}
\hline Outcomes & - Headache relief at $2 \mathrm{~h}$ (reduction from moderate or severe to mild or no pain) \\
& - Pain-free at $2 \mathrm{~h}$ \\
& - Headache recurrence (from 2 to $24 \mathrm{~h}$ ) \\
& - Rescue medication (from 2 to $24 \mathrm{~h}$ ) \\
& - Adsociated symptoms (nausea, vomiting) (within $2 \mathrm{~h}$ ) \\
& Other reported outcomes: \\
& - Photophobia or phonophobia within $2 \mathrm{~h}$ \\
\hline Headache severity scale & 4-level (none, mild, moderate, severe) \\
\hline Funding source & GlaxoSmithKline \\
\hline Publication & Journal and clinical trial registry \\
\hline Notes & -
\end{tabular}

\section{Risk of bias}

\begin{tabular}{|c|c|c|}
\hline Bias & Authors' judgement & Support for judgement \\
\hline $\begin{array}{l}\text { Random sequence genera- } \\
\text { tion (selection bias) }\end{array}$ & Low risk & $\begin{array}{l}\text { Quote: "Patients were randomized after successful screening using a comput- } \\
\text { er-generated, parallel-group design, 1:1:1:1 ratio (block size of } 8 \text { )" }\end{array}$ \\
\hline $\begin{array}{l}\text { Allocation concealment } \\
\text { (selection bias) }\end{array}$ & Low risk & $\begin{array}{l}\text { Quote: "The allocation schedule was concealed in tamper-evident, blinded en- } \\
\text { velopes kept by the sponsor" }\end{array}$ \\
\hline $\begin{array}{l}\text { Blinding (performance } \\
\text { bias and detection bias) } \\
\text { All outcomes }\end{array}$ & Low risk & Quote: "identically appearing placebo" \\
\hline $\begin{array}{l}\text { Incomplete outcome data } \\
\text { (attrition bias) } \\
\text { All outcomes }\end{array}$ & Low risk & Comment: missing outcome data balanced across intervention groups \\
\hline $\begin{array}{l}\text { Selective reporting (re- } \\
\text { porting bias) }\end{array}$ & Low risk & Comment: all expected outcomes reported \\
\hline
\end{tabular}


Winner 2002

\section{Study characteristics}

\begin{tabular}{|c|c|}
\hline Methods & Randomized, double-blind, placebo-controlled, parallel-group trial of oral rizatriptan \\
\hline \multirow[t]{2}{*}{ Participants } & $\begin{array}{l}\text { Participants were } 12-17 \text { yrs, with an average of at least } 1 \text { but no more than } 8 \text { migraines per IHS } 1988 \text { cri- } \\
\text { teria and stratified in } 2 \text { groups: } 12-14 \text { years and } 15-17 \text { years. Efforts were made to enrol equal numbers } \\
\text { in each age group. }\end{array}$ \\
\hline & Randomized $(N=360)$; did not receive study medication $(N=64)$; primary efficacy analysis $(N=296)$ \\
\hline Interventions & $\begin{array}{l}\text { Each participant was instructed to take the study medication (rizatriptan } 5 \mathrm{mg} \text { or placebo) within } 30 \\
\text { min of onset of a moderate or severe migraine }\end{array}$ \\
\hline \multirow[t]{9}{*}{ Outcomes } & - Pain-free at $2 \mathrm{~h}$ \\
\hline & - Headache relief (reduction in pain to mild or none) at $2 \mathrm{~h}$ \\
\hline & - Presence of nausea \\
\hline & - Use of rescue medication \\
\hline & - Headache recurrence (within $24 \mathrm{~h}$ ) \\
\hline & - Adverse events \\
\hline & Other reported outcomes: \\
\hline & - Presence of photophobia or phonophobia \\
\hline & - Functional disability \\
\hline Headache severity scale & 4-level (none, mild, moderate, severe) \\
\hline Funding source & Merck \\
\hline Publication & Journal \\
\hline Notes & - \\
\hline
\end{tabular}

\section{Risk of bias}

\begin{tabular}{|c|c|c|}
\hline Bias & Authors' judgement & Support for judgement \\
\hline $\begin{array}{l}\text { Random sequence genera- } \\
\text { tion (selection bias) }\end{array}$ & Unclear risk & Quote: "Patients were randomly assigned" \\
\hline $\begin{array}{l}\text { Allocation concealment } \\
\text { (selection bias) }\end{array}$ & Unclear risk & Comment: no information provided. \\
\hline $\begin{array}{l}\text { Blinding (performance } \\
\text { bias and detection bias) } \\
\text { All outcomes }\end{array}$ & Unclear risk & Comment: no information provided \\
\hline $\begin{array}{l}\text { Incomplete outcome data } \\
\text { (attrition bias) } \\
\text { All outcomes }\end{array}$ & High risk & $\begin{array}{l}\text { Comment: small imbalance of missing outcome data in the placebo group }(\mathrm{N}= \\
6 \mathrm{vs} N=1)\end{array}$ \\
\hline $\begin{array}{l}\text { Selective reporting (re- } \\
\text { porting bias) }\end{array}$ & Low risk & Comment: all expected outcomes reported \\
\hline
\end{tabular}


Winner 2006

\section{Study characteristics}

\begin{tabular}{|c|c|}
\hline Methods & $\begin{array}{l}\text { Randomized, double-blind, placebo-controlled, parallel-group, multicenter, single-attack, outpatient } \\
\text { study of intranasal sumatriptan }\end{array}$ \\
\hline \multirow[t]{2}{*}{ Participants } & $\begin{array}{l}\text { Participants were } 12-17 \text { years of age; had a history of migraine of at least } 6 \text { months duration (with or } \\
\text { without aura) in accordance with IHS 1988; had at least 1-8 moderate or severe migraine attacks per } \\
\text { month in each of the } 2 \text { months before study enrolment; and were able to distinguish migraine attacks } \\
\text { as discrete attacks, separate from other headaches (i.e., tension headaches) }\end{array}$ \\
\hline & $\begin{array}{l}\text { Randomized ( } N=888) \text {; did not receive study medication }(N=150) \text {; withdrawn }(N=7) \text {; intention-to-treat } \\
\text { and primary efficacy analysis }(N=731)\end{array}$ \\
\hline Interventions & Sumatriptan 5 mg nasal spray; sumatriptan 20 mg nasal spray; or placebo \\
\hline \multirow[t]{5}{*}{ Outcomes } & $\begin{array}{l}\text { - Headache relief at } 2 \mathrm{~h} \text { (grade } 2 \text { or } 3 \text { reduced to } 0 \text { or } 1 \text { ) (relief at } 1 \mathrm{~h} \text { was the study primary outcome) } \\
\text { - Pain-free } \\
\text { - Presense of nausea } \\
\text { - Use of rescue medications (within } 24 \mathrm{~h} \text { ) } \\
\text { - Headache recurrence (within } 24 \mathrm{~h} \text { ) } \\
\text { - Adverse events }\end{array}$ \\
\hline & Other reported outcomes: \\
\hline & - Sustained pain-freedom to $24 \mathrm{~h}$ \\
\hline & - Sustained headache relief from $2-24 \mathrm{~h}$ \\
\hline & - Presence of photophobia or phonophobia (within $2 \mathrm{~h}$ ) \\
\hline
\end{tabular}

\begin{tabular}{ll}
\hline Headache severity scale & 4-level (none, mild, moderate, severe) \\
\hline Funding source & GlaxoSmithKline \\
\hline Publication & Journal and clinical trial registry \\
\hline Notes & - \\
\hline
\end{tabular}

\section{Risk of bias}

\begin{tabular}{lll}
\hline Bias & Authors' judgement & Support for judgement \\
\hline $\begin{array}{l}\text { Random sequence genera- } \\
\text { tion (selection bias) }\end{array}$ & Low risk & $\begin{array}{l}\text { Quote: "randomized in a 1:1:1 ratio (in blocks of six) to one of three treatment } \\
\text { groups"; "computer-generated randomization schedule" }\end{array}$ \\
& $\begin{array}{l}\text { Comment: previous migraine studies by GlaxoSmithKline have documented } \\
\text { acceptable sequence generation (e.g. Winner 2000) }\end{array}$ \\
\hline $\begin{array}{l}\text { Allocation concealment } \\
\text { (selection bias) }\end{array}$ & Low risk & Quote: "randomization schedule prepared by the sponsor" \\
\hline $\begin{array}{l}\text { Blinding (performance } \\
\text { bias and detection bias) }\end{array}$ & Low risk & Comment: centralized allocation \\
\hline $\begin{array}{l}\text { All outcomes } \\
\begin{array}{l}\text { Incomplete outcome data } \\
\text { All outcomes }\end{array}\end{array}$ & $\begin{array}{l}\text { Quote: "[nasal spray] devices for active drug and placebo were identical in ap- } \\
\text { pearance and construction to maintain the study blind." }\end{array}$ \\
\hline
\end{tabular}


Winner 2006 (Continued)

Selective reporting (re- Low risk Comment: missing outcome data balanced across intervention groups porting bias)

Winner 2007

\section{Study characteristics}

\begin{tabular}{|c|c|}
\hline Methods & Randomized, double-blind, parallel-group, placebo-controlled trial of oral eletriptan \\
\hline Participants & $\begin{array}{l}\text { Participants were } 12-17 \text { years, met ICHD-2 criteria for migraine with or without aura, and suffered at } \\
\text { least } 1 \text { migraine attack every } 6 \text { weeks. Mean migraine duration was required to be a minimum of } 4 \mathrm{~h} \text {. } \\
\text { Randomized }(\mathrm{N}=348) \text {; did not receive study medication ( } N=74) \text {; intention-to-treat and primary effica- } \\
\text { cy analysis }(\mathrm{N}=274)\end{array}$ \\
\hline Interventions & Eletriptan $40 \mathrm{mg}$ PO, placebo taken within $4 \mathrm{~h}$ of headache onset \\
\hline Outcomes & $\begin{array}{l}\text { - Headache relief at } 2 \mathrm{~h} \text { (reduction from moderate or severe to mild or no pain) } \\
\text { - Pain-free at } 2 \mathrm{~h} \\
\text { - } \text { Presense of nausea } \\
\text { - Headache recurrence (within } 2 \text { to } 24 \mathrm{~h} \text { ) } \\
\text { - Adverse events } \\
\text { Other reported outcomes: } \\
\text { - Headache relief and pain-free at } 1 \mathrm{~h} \\
\text { - Presence of photophobia or phonophobia } \\
\text { - Change in functional impairment } \\
\text { - Migraine-free (no headache and no associated symptoms at } 2 \mathrm{~h} \\
\text { - Acceptability of medication }\end{array}$ \\
\hline Headache severity scale & 4-level (none, mild, moderate, severe) \\
\hline Funding source & Pfizer \\
\hline Publication & Journal \\
\hline Notes & - \\
\hline
\end{tabular}

\section{Risk of bias}

\begin{tabular}{lll}
\hline Bias & Authors' judgement & Support for judgement \\
\hline $\begin{array}{l}\text { Random sequence genera- } \\
\text { tion (selection bias) }\end{array}$ & Unclear risk & Comment: no information provided \\
\hline $\begin{array}{l}\text { Allocation concealment } \\
\text { (selection bias) }\end{array}$ & Unclear risk & Comment: no information provided \\
\hline $\begin{array}{l}\text { Blinding (performance } \\
\text { bias and detection bias) } \\
\begin{array}{l}\text { All outcomes } \\
\hline\end{array}\end{array}$ & Unclear risk & Comment: described as "placebo-controlled", but no other description \\
\hline
\end{tabular}


Winner 2007 (Continued)

Incomplete outcome data Low risk Quote: "Three hundred and eighty-four were screened, of whom 348 were ran(attrition bias) domized to study drug ..."; "Seventy-four were randomized but did not take All outcomes the study drug: (1) 35 did not treat a migraine attack during the 12-week time window..."

Comment: withdrawals balanced across intervention groups

$\begin{array}{ll}\begin{array}{l}\text { Selective reporting (re- } \\ \text { porting bias) }\end{array} & \text { Low risk } \\ \end{array}$

AE: adverse events; DHE: dihydroergotamine; LOCF: last observation carried forward; PO: per os (by mouth); VAS: visual analogue scale.

Characteristics of excluded studies [ordered by study ID]

\begin{tabular}{|c|c|}
\hline Study & Reason for exclusion \\
\hline Brousseau 2004 & $\begin{array}{l}\text { The Emergency Department setting and parenteral interventions studied (intravenous prochlor- } \\
\text { perazine versus ketorolac) were significantly different from included clinical trials of interventions } \\
\text { in the outpatient setting. As there were few other clinical trials in the Emergency Department set- } \\
\text { ting, we made a post hoc decision to exclude this study to simplify the review conclusions. }\end{array}$ \\
\hline Cady 2011 & Non-drug clinical trial and participants were not exclusively pediatric \\
\hline Gertsch 2011 & Open-label, uncontrolled study \\
\hline NCT00355394 & $\begin{array}{l}\text { The Emergency Department setting and parenteral intervention studied (intravenous metoclo- } \\
\text { pramide) was significantly different from included clinical trials of interventions in the outpatient } \\
\text { setting. As there were few other clinical trials in the Emergency Department setting, we made a } \\
\text { post hoc decision to exclude this study to simplify the review conclusions. }\end{array}$ \\
\hline Soriani 2001 & $\begin{array}{l}\text { A non-placebo-controlled randomized study comparing paracetamol and nimesulide. Each of } 60 \\
\text { participants in the study treated } 10 \text { attacks, and the primary outcome of headache relief was re- } \\
\text { ported as a percentage of attacks. No individual participant data was reported so was not included } \\
\text { in the meta-analysis. }\end{array}$ \\
\hline SUM40090 & Open-label, uncontrolled study \\
\hline Trautmann 2010 & Non-drug clinical trial \\
\hline Winner 2011 & Study of rapid disintegrating formulation of sumatriptan was not a randomized controlled trial \\
\hline
\end{tabular}

Characteristics of studies awaiting classification [ordered by study ID]

Winner 2015

$\begin{array}{ll}\text { Methods } & \begin{array}{l}\text { Randomized, placebo-controlled, double-blind cross-over trial of oral sumatriptan }+ \text { naproxen } \\ \text { sodium }\end{array}\end{array}$

Participants

Male and female adolescents $12-17$ years of age meeting ICHD-2 criteria with an average of at least 1 but no more than 8 migraines per month in the previous 6 months

Enrolled ( $N=104)$; did not receive study medication $(N=10)$; primary efficacy analysis $(N=94)$ 
Winner 2015 (Continued)

Interventions

Sumatriptan + naproxen sodium $85 \mathrm{mg}+500 \mathrm{mg}$; or placebo for the treatment of 4 migraine attacks ( 3 active, 1 placebo)

Outcomes

- Pain freedom at $2 \mathrm{~h}$ (post-treatment pain severity of 0 with no use of rescue medication)

- Presense of nausea or vomiting

- Use of rescue medications (within $24 \mathrm{~h}$ )

- Headache recurrence from 2-24 h

- Adverse event

Other reported outcomes:

- Presence of photophobia or phonophobia

DATA AND ANALYSES

\section{Comparison 1. Ibuprofen vs placebo in children}

\begin{tabular}{lllll}
\hline $\begin{array}{l}\text { Outcome or subgroup ti- } \\
\text { tle }\end{array}$ & No. of studies & $\begin{array}{l}\text { No. of partici- } \\
\text { pants }\end{array}$ & Statistical method & Effect size \\
\hline 1.1 Pain-free & 2 & 125 & Risk Ratio (M-H, Random, 95\% Cl) & $1.87[1.15,3.04]$ \\
\hline 1.2 Adverse events (any) & 1 & 80 & $\begin{array}{l}\text { Risk Difference (M-H, Random, 95\% } \\
\text { Cl) }\end{array}$ & $0.00[-0.13,0.13]$ \\
\hline 1.3 Headache relief & 2 & Risk Ratio (M-H, Random, 95\% Cl) & $1.49[1.11,2.00]$ \\
\hline 1.4 Rescue medication & 2 & 125 & Risk Ratio (M-H, Random, 95\% Cl) & $0.19[0.02,1.56]$ \\
\hline 1.5 Headache recurrence & 1 & 164 & Risk Ratio (M-H, Fixed, 95\% Cl) & $0.25[0.01,5.68]$ \\
\hline
\end{tabular}

Analysis 1.1. Comparison 1: Ibuprofen vs placebo in children, Outcome 1: Pain-free

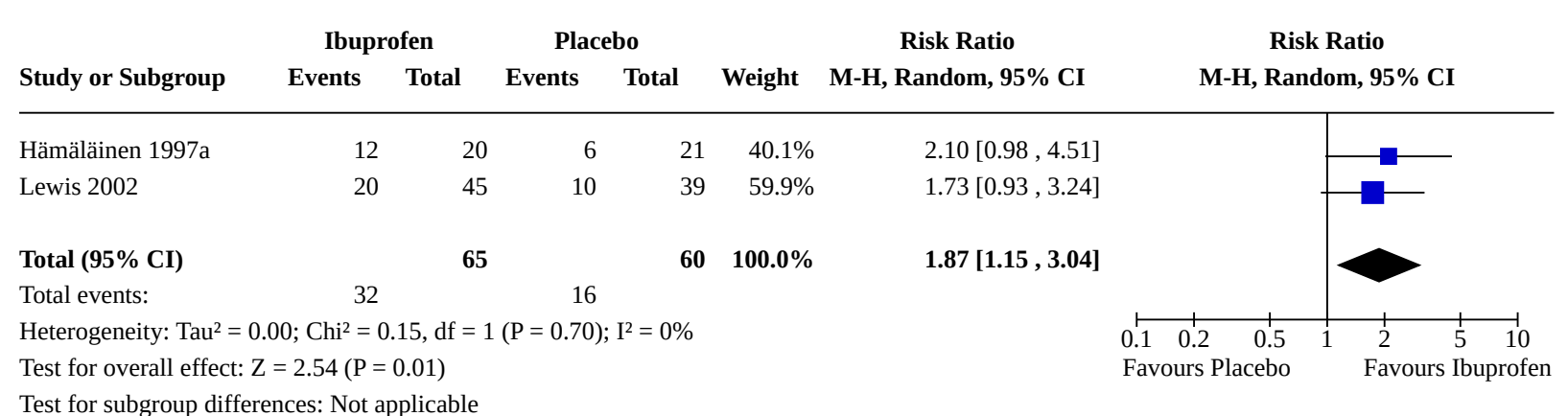


Analysis 1.2. Comparison 1: Ibuprofen vs placebo in children, Outcome 2: Adverse events (any)

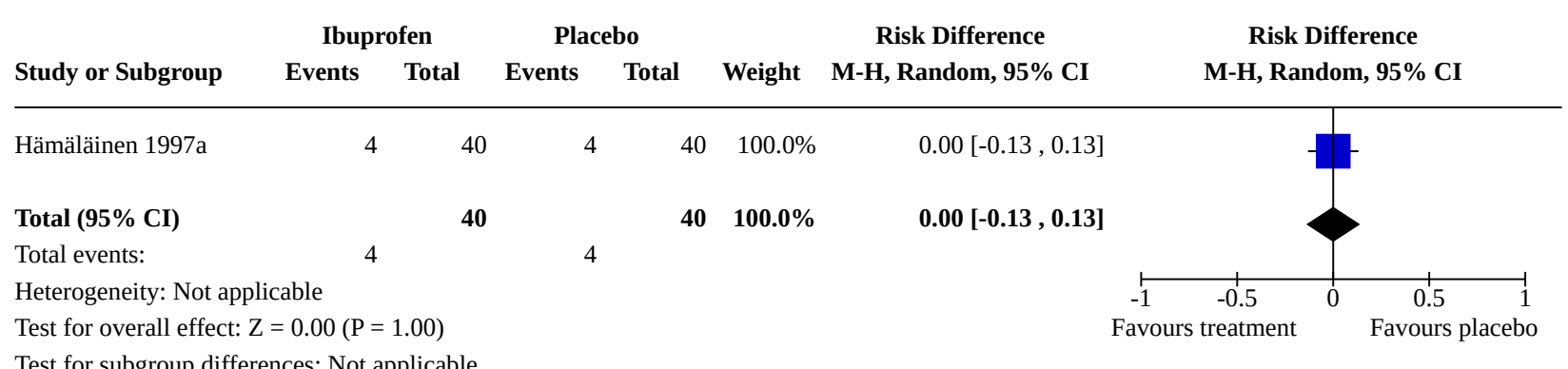

Analysis 1.3. Comparison 1: Ibuprofen vs placebo in children, Outcome 3: Headache relief

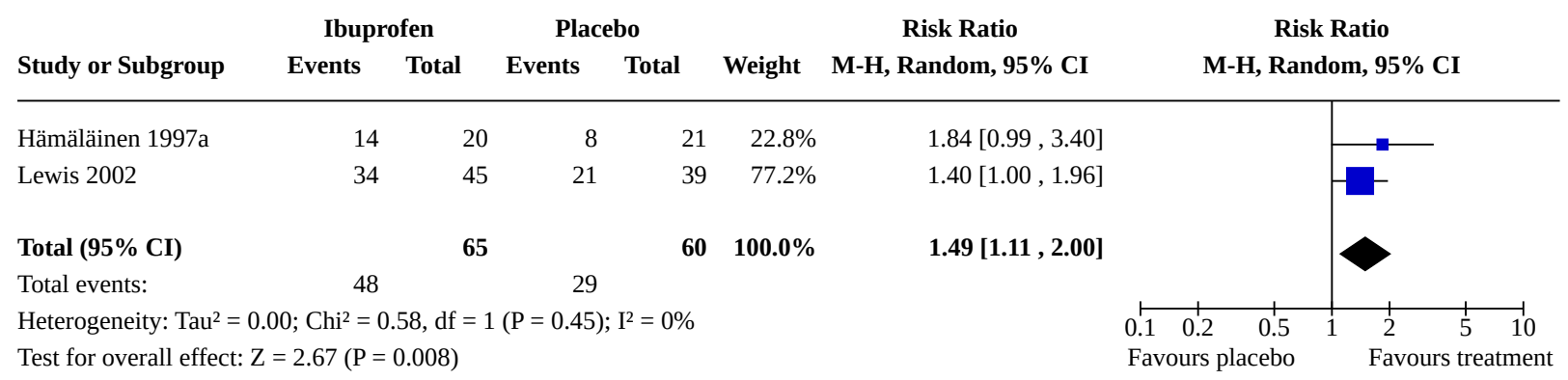

Test for subgroup differences: Not applicable

\section{Analysis 1.4. Comparison 1: Ibuprofen vs placebo in children, Outcome 4: Rescue medication}

\begin{tabular}{|c|c|c|c|c|c|c|c|}
\hline & Ibup & & & & & Risk Ratio & Risk Ratio \\
\hline Study or Subgroup & Events & Total & Events & Total & Weight & M-H, Random, 95\% CI & M-H, Random, 95\% CI \\
\hline
\end{tabular}

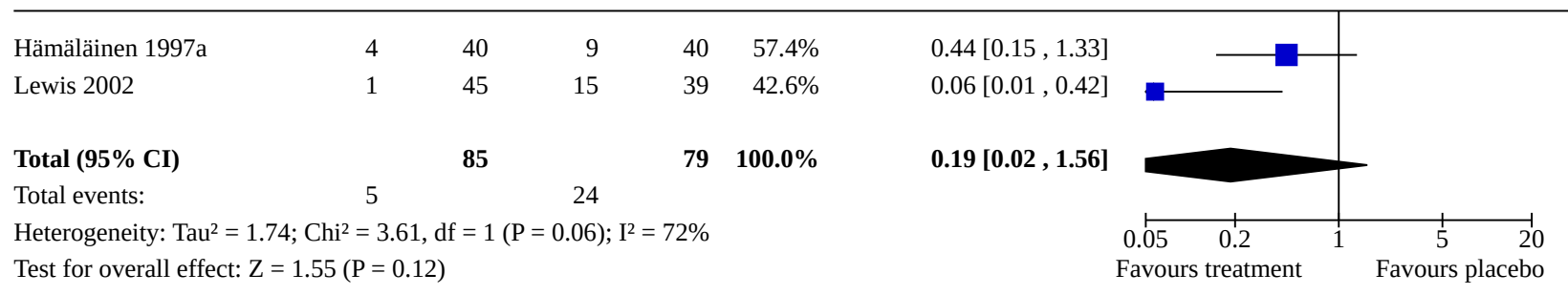

Test for subgroup differences: Not applicable

Analysis 1.5. Comparison 1: Ibuprofen vs placebo in children, Outcome 5: Headache recurrence

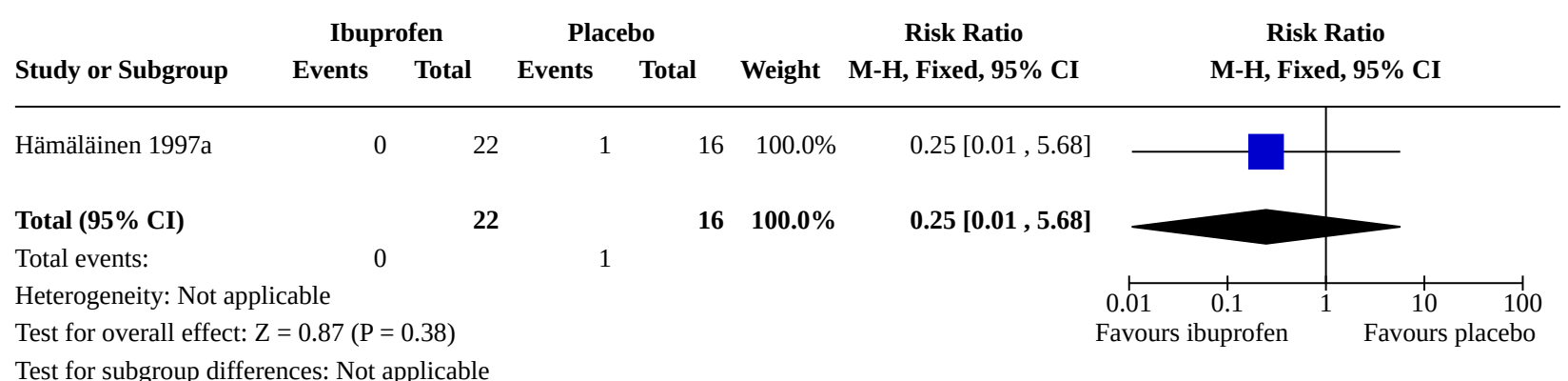


Comparison 2. Triptans vs placebo in children

\begin{tabular}{|c|c|c|c|c|}
\hline $\begin{array}{l}\text { Outcome or subgroup } \\
\text { title }\end{array}$ & No. of studies & $\begin{array}{l}\text { No. of partici- } \\
\text { pants }\end{array}$ & Statistical method & Effect size \\
\hline 2.1 Pain-free & 3 & 345 & Risk Ratio (M-H, Random, 95\% Cl) & $1.67[1.06,2.62]$ \\
\hline 2.1.1 Rizatriptan & 1 & 200 & Risk Ratio (M-H, Random, 95\% Cl) & $1.31[0.89,1.92]$ \\
\hline 2.1.2 Sumatriptan & 2 & 145 & Risk Ratio (M-H, Random, 95\% Cl) & $2.29[1.00,5.23]$ \\
\hline 2.2 Adverse events (any) & 3 & 420 & Risk Difference (M-H, Random, 95\% Cl) & $0.06[-0.04,0.17]$ \\
\hline 2.2.1 Rizatriptan & 1 & 275 & Risk Difference (M-H, Random, 95\% Cl) & $0.00[-0.09,0.09]$ \\
\hline 2.2.2 Sumatriptan & 2 & 145 & Risk Difference (M-H, Random, 95\% Cl) & $0.13[0.01,0.26]$ \\
\hline 2.3 Headache relief & 3 & 345 & Risk Ratio (M-H, Random, 95\% Cl) & $1.36[0.88,2.08]$ \\
\hline 2.3.1 Rizatriptan & 1 & 200 & Risk Ratio (M-H, Random, 95\% Cl) & $0.97[0.75,1.24]$ \\
\hline 2.3.2 Sumatriptan & 2 & 145 & Risk Ratio (M-H, Random, 95\% Cl) & $1.65[1.21,2.26]$ \\
\hline 2.4 Rescue medication & 2 & 145 & Risk Ratio (M-H, Random, 95\% Cl) & $0.31[0.06,1.45]$ \\
\hline 2.4.1 Sumatriptan & 2 & 145 & Risk Ratio (M-H, Random, 95\% Cl) & $0.31[0.06,1.45]$ \\
\hline $\begin{array}{l}2.5 \text { Headache recur- } \\
\text { rence }\end{array}$ & 1 & 18 & Risk Ratio (M-H, Random, 95\% Cl) & Not estimable \\
\hline 2.5.1 Sumatriptan & 1 & 18 & Risk Ratio (M-H, Random, 95\% Cl) & Not estimable \\
\hline 2.6 Presence of nausea & 3 & 345 & Risk Ratio (M-H, Random, 95\% Cl) & $0.64[0.46,0.90]$ \\
\hline 2.6.1 Rizatriptan & 1 & 200 & Risk Ratio (M-H, Random, 95\% Cl) & $0.68[0.38,1.22]$ \\
\hline 2.6.2 Sumatriptan & 2 & 145 & Risk Ratio (M-H, Random, 95\% Cl) & $0.62[0.42,0.94]$ \\
\hline $\begin{array}{l}2.7 \text { Presence of vomit- } \\
\text { ing }\end{array}$ & 3 & 345 & Risk Ratio (M-H, Random, 95\% Cl) & $0.50[0.13,1.86]$ \\
\hline 2.7.1 Rizatriptan & 1 & 200 & Risk Ratio (M-H, Random, 95\% Cl) & $1.73[0.43,7.06]$ \\
\hline 2.7.2 Sumatriptan & 2 & 145 & Risk Ratio (M-H, Random, 95\% Cl) & $0.30[0.09,0.99]$ \\
\hline
\end{tabular}




\section{Analysis 2.1. Comparison 2: Triptans vs placebo in children, Outcome 1: Pain-free}

\begin{tabular}{lcccccc} 
& \multicolumn{2}{c}{ Triptan } & \multicolumn{2}{c}{ Placebo } & Risk Ratio & Risk Ratio \\
Study or Subgroup & Events & Total & Events $\quad$ Total & Weight & M-H, Random, 95\% CI & M-H, Random, 95\% CI
\end{tabular}

\subsubsection{Rizatriptan}

Ho 2012

Subtotal (95\% CI)

$39 \quad 98$

31

$102 \quad 50.9 \%$

$1.31[0.89,1.92]$

Total events:

98

$102 \quad 50.9 \%$

$1.31[0.89,1.92]$

Heterogeneity: Not applicable

Test for overall effect: $\mathrm{Z}=1.38(\mathrm{P}=0.17)$

\subsubsection{Sumatriptan}

Ueberall 1999

Hämäläinen 2002

Subtotal (95\% CI)

9

14

31

Total events:

27

59

2

$14 \quad 10.0 \%$

$4.50[1.18,17.21]$

$1.77[1.06,2.97]$

$2.29[1.00,5.23]$

Heterogeneity: $\mathrm{Tau}^{2}=0.18 ; \mathrm{Chi}^{2}=1.65, \mathrm{df}=1(\mathrm{P}=0.20) ; \mathrm{I}^{2}=40 \%$

Test for overall effect: $\mathrm{Z}=1.97(\mathrm{P}=0.05)$

\section{Total (95\% CI)}

171

$174 \quad 100.0 \%$

Total events: 75

48

Heterogeneity: $\mathrm{Tau}^{2}=0.07 ; \mathrm{Chi}^{2}=3.47, \mathrm{df}=2(\mathrm{P}=0.18) ; \mathrm{I}^{2}=42 \%$

Test for overall effect: $\mathrm{Z}=2.21(\mathrm{P}=0.03)$

Test for subgroup differences: $\mathrm{Chi}^{2}=1.45, \mathrm{df}=1(\mathrm{P}=0.23), \mathrm{I}^{2}=30.9 \%$

$1.67[1.06,2.62]$

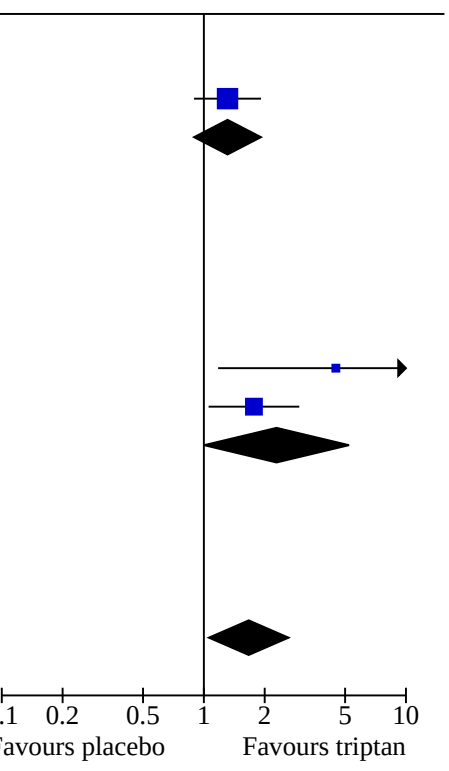

Analysis 2.2. Comparison 2: Triptans vs placebo in children, Outcome 2: Adverse events (any)
Triptan
Placebo
Risk Difference
Risk Difference

Study or Subgroup Events Total Events Total

Weight M-H, Random, 95\% CI M-H, Random, 95\% CI

2.2.1 Rizatriptan

Ho 2012

Subtotal (95\% CI)

$25 \quad 125$

$125 \quad 30$

$150 \quad 53.0 \%$

$0.00[-0.09,0.09]$

Total events:

$125 \quad 30$

$150 \quad 53.0 \%$

$0.00[-0.09,0.09]$

Heterogeneity: Not applicable

Test for overall effect: $\mathrm{Z}=0.00(\mathrm{P}=1.00)$

\subsubsection{Sumatriptan}

Ueberall 1999

Hämäläinen 2002

Subtotal (95\% CI)

3

14

30

Total events:

16

2

$14 \quad 12.1 \%$

$0.07[-0.21,0.35]$

0.15 [0.01, 0.29]

$0.13[0.01,0.26]$

Heterogeneity: $\mathrm{Tau}^{2}=0.00 ; \mathrm{Chi}^{2}=0.24, \mathrm{df}=1(\mathrm{P}=0.62) ; \mathrm{I}^{2}=0 \%$

Test for overall effect: $\mathrm{Z}=2.09(\mathrm{P}=0.04)$

\section{Total (95\% CI)}

198

$222 \quad 100.0 \%$

Total events:

44

39

Heterogeneity: $\mathrm{Tau}^{2}=0.00 ; \mathrm{Chi}^{2}=3.04, \mathrm{df}=2(\mathrm{P}=0.22) ; \mathrm{I}^{2}=34 \%$

Test for overall effect: $\mathrm{Z}=1.14(\mathrm{P}=0.26)$

Test for subgroup differences: $\mathrm{Chi}^{2}=2.80, \mathrm{df}=1(\mathrm{P}=0.09), \mathrm{I}^{2}=64.2 \%$ 


\section{Analysis 2.3. Comparison 2: Triptans vs placebo in children, Outcome 3: Headache relief}

\begin{tabular}{|c|c|c|c|c|c|c|c|}
\hline \multirow[b]{2}{*}{ Study or Subgroup } & \multicolumn{2}{|c|}{ Triptan } & \multicolumn{2}{|c|}{ Placebo } & \multirow[b]{2}{*}{ Weight } & \multirow{2}{*}{$\begin{array}{c}\text { Risk Ratio } \\
\text { M-H, Random, 95\% CI }\end{array}$} & \multirow{2}{*}{$\begin{array}{c}\text { Risk Ratio } \\
\text { M-H, Random, } \mathbf{9 5 \% ~ C ~}\end{array}$} \\
\hline & Events & Total & Events & Total & & & \\
\hline \multicolumn{8}{|l|}{ 2.3.1 Rizatriptan } \\
\hline Ho 2012 & 53 & 98 & 57 & 102 & $41.2 \%$ & $0.97[0.75,1.24]$ & \\
\hline Subtotal (95\% CI) & & 98 & & 102 & $41.2 \%$ & $0.97[0.75,1.24]$ & \\
\hline Total events: & 53 & & 57 & & & & \\
\hline \multicolumn{8}{|c|}{ Heterogeneity: Not applicable } \\
\hline \multicolumn{8}{|c|}{ Test for overall effect: $\mathrm{Z}=0.26(\mathrm{P}=0.80)$} \\
\hline \multicolumn{8}{|l|}{ 2.3.2 Sumatriptan } \\
\hline Ueberall 1999 & 12 & 14 & 6 & 14 & $23.1 \%$ & $2.00[1.05,3.80]$ & $=$ \\
\hline Hämäläinen 2002 & 38 & 59 & 24 & 58 & $35.8 \%$ & $1.56[1.09,2.23]$ & \\
\hline Subtotal $(95 \%$ CI) & & 73 & & 72 & $58.8 \%$ & $1.65[1.21,2.26]$ & \\
\hline Total events: & 50 & & 30 & & & & \\
\hline \multicolumn{8}{|c|}{ Heterogeneity: $\mathrm{Tau}^{2}=0.00 ; \mathrm{Chi}^{2}=0.45, \mathrm{df}=1(\mathrm{P}=0.50) ; \mathrm{I}^{2}=0 \%$} \\
\hline \multicolumn{8}{|c|}{ Test for overall effect: $\mathrm{Z}=3.14(\mathrm{P}=0.002)$} \\
\hline Total $(95 \%$ CI) & & 171 & & 174 & $100.0 \%$ & $1.36[0.88,2.08]$ & \\
\hline Total events: & 103 & & 87 & & & & \\
\hline \multicolumn{7}{|c|}{ Heterogeneity: $\mathrm{Tau}^{2}=0.10 ; \mathrm{Chi}^{2}=7.27, \mathrm{df}=2(\mathrm{P}=0.03) ; \mathrm{I}^{2}=72 \%$} & $0.1 \quad 0.2 \quad 0.5$ \\
\hline \multicolumn{7}{|c|}{ Test for overall effect: $\mathrm{Z}=1.40(\mathrm{P}=0.16)$} & Favours placebo \\
\hline
\end{tabular}

\section{Analysis 2.4. Comparison 2: Triptans vs placebo in children, Outcome 4: Rescue medication}

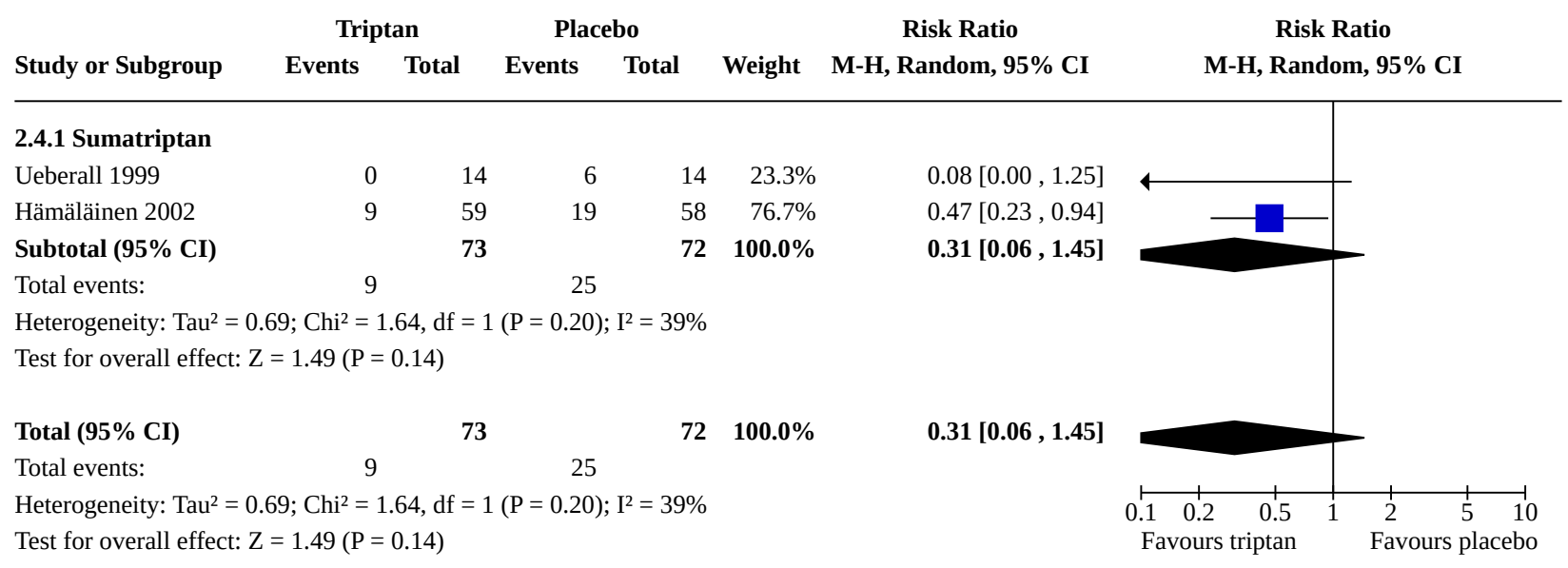


Analysis 2.5. Comparison 2: Triptans vs placebo in children, Outcome 5: Headache recurrence

\begin{tabular}{|c|c|c|c|c|c|c|c|c|}
\hline \multirow{3}{*}{$\begin{array}{l}\text { Study or Subgroup } \\
\text { 2.5.1 Sumatriptan }\end{array}$} & \multicolumn{2}{|c|}{ Triptan } & \multicolumn{2}{|c|}{ Placebo } & \multirow[b]{2}{*}{ Weight } & \multirow{2}{*}{$\begin{array}{c}\text { Risk Ratio } \\
\text { M-H, Random, 95\% CI }\end{array}$} & \multirow{2}{*}{\multicolumn{2}{|c|}{$\begin{array}{c}\text { Risk Ratio } \\
\text { M-H, Random, 95\% CI }\end{array}$}} \\
\hline & Events & Total & Events & Total & & & & \\
\hline & & & & & & & & \\
\hline Ueberall 1999 & 0 & 12 & 0 & & 6 & Not estimable & & \\
\hline Subtotal $(95 \%$ CI) & & 12 & & & 6 & Not estimable & & \\
\hline Total events: & 0 & & 0 & & & & & \\
\hline \multicolumn{9}{|c|}{ Heterogeneity: Not applicable } \\
\hline \multicolumn{9}{|c|}{ Test for overall effect: Not applicable } \\
\hline Total $(95 \%$ CI) & & 12 & & & 6 & Not estimable & & \\
\hline Total events: & 0 & & 0 & & & & & \\
\hline Heterogeneity: Not ap & cable & & & & & & $\begin{array}{lll}0.1 & 0.2 & 0.5\end{array}$ & $\begin{array}{lll}1 & 1 & 1 \\
2 & 5 & 10\end{array}$ \\
\hline Test for overall effect & t applicabl & & & & & & Favours triptan & Favours placebo \\
\hline
\end{tabular}

\section{Analysis 2.6. Comparison 2: Triptans vs placebo in children, Outcome 6: Presence of nausea}

\begin{tabular}{lcccccc} 
& \multicolumn{2}{c}{ Triptan } & \multicolumn{2}{c}{ Placebo } & Risk Ratio & Risk Ratio \\
Study or Subgroup & Events & Total & Events $\quad$ Total & Weight & M-H, Random, 95\% CI & M-H, Random, 95\% CI
\end{tabular}

\begin{tabular}{lcccccc}
\hline 2.6.1 Rizatriptan & & & & & & \\
Ho 2012 & 15 & 98 & 23 & 102 & $32.5 \%$ & $0.68[0.38,1.22]$ \\
Subtotal (95\% CI) & & $\mathbf{9 8}$ & & $\mathbf{1 0 2}$ & $\mathbf{3 2 . 5 \%}$ & $\mathbf{0 . 6 8}[\mathbf{0 . 3 8}, \mathbf{1 . 2 2}]$ \\
Total events: & 15 & & 23 & & &
\end{tabular}

Heterogeneity: Not applicable

Test for overall effect: $\mathrm{Z}=1.29(\mathrm{P}=0.20)$

\subsubsection{Sumatriptan}

\section{Ueberall 1999}

Hämäläinen 2002

Subtotal (95\% CI)

Total events:

$\begin{array}{rr}3 & 14 \\ 20 & 59 \\ & 73\end{array}$

14
59
73

29

Heterogeneity: $\mathrm{Tau}^{2}=0.00 ; \mathrm{Chi}^{2}=0.97, \mathrm{df}=1(\mathrm{P}=0.33) ; \mathrm{I}^{2}=0 \%$ Test for overall effect: $\mathrm{Z}=2.26(\mathrm{P}=0.02)$

Total (95\% CI)

171

$174 \quad 100.0 \%$

Total events: 38 60

Heterogeneity: $\mathrm{Tau}^{2}=0.00 ; \mathrm{Chi}^{2}=1.01, \mathrm{df}=2(\mathrm{P}=0.60) ; \mathrm{I}^{2}=0 \%$

Test for overall effect: $\mathrm{Z}=2.59(\mathrm{P}=0.010)$

Test for subgroup differences: $\mathrm{Chi}^{2}=0.05, \mathrm{df}=1(\mathrm{P}=0.82), \mathrm{I}^{2}=0 \%$

$0.38[0.12,1.13]$
$0.68[0.44,1.05]$
$\mathbf{0 . 6 2}[\mathbf{0 . 4 2}, \mathbf{0 . 9 4}]$

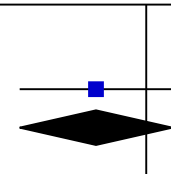


Analysis 2.7. Comparison 2: Triptans vs placebo in children, Outcome 7: Presence of vomiting

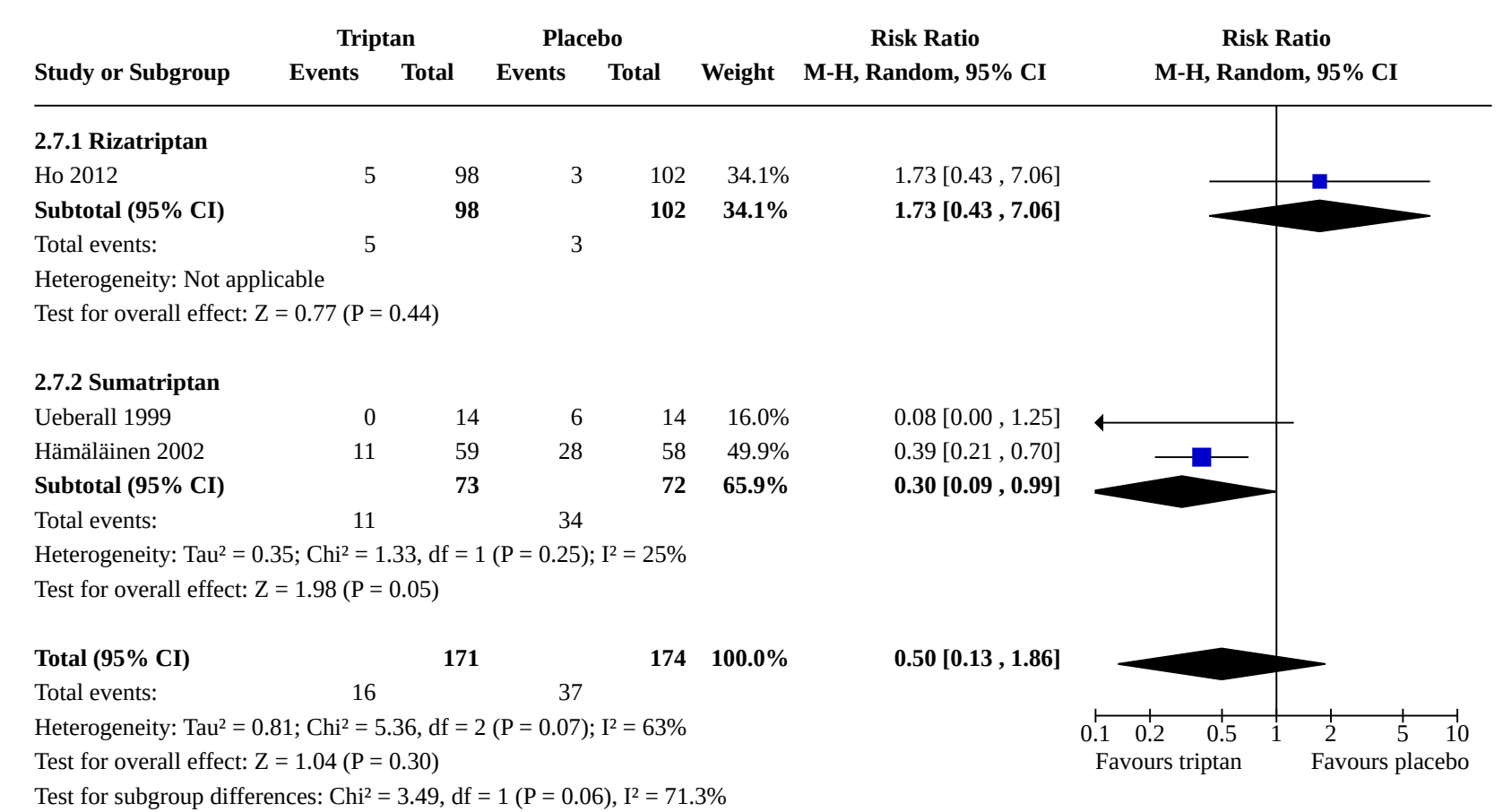

\section{Comparison 3. Triptans vs placebo in adolescents}

\begin{tabular}{|c|c|c|c|c|}
\hline $\begin{array}{l}\text { Outcome or subgroup } \\
\text { title }\end{array}$ & No. of studies & $\begin{array}{l}\text { No. of partici- } \\
\text { pants }\end{array}$ & Statistical method & Effect size \\
\hline 3.1 Pain-free & 21 & 6761 & Risk Ratio (M-H, Random, 95\% Cl) & $1.32[1.19,1.47]$ \\
\hline 3.1.1 Almotriptan & 1 & 714 & Risk Ratio (M-H, Random, 95\% Cl) & $1.10[0.88,1.39]$ \\
\hline 3.1.2 Eletriptan & 1 & 274 & Risk Ratio (M-H, Random, 95\% Cl) & $1.46[0.88,2.43]$ \\
\hline 3.1.3 Naratriptan & 1 & 300 & Risk Ratio (M-H, Random, 95\% Cl) & $1.06[0.65,1.75]$ \\
\hline 3.1.4 Rizatriptan & 4 & 1526 & Risk Ratio (M-H, Random, 95\% Cl) & $1.34[1.13,1.60]$ \\
\hline 3.1.5 Sumatriptan & 10 & 2415 & Risk Ratio (M-H, Random, 95\% Cl) & $1.27[1.10,1.48]$ \\
\hline 3.1.6 Zolmitriptan & 4 & 1532 & Risk Ratio (M-H, Random, 95\% Cl) & $1.66[1.16,2.38]$ \\
\hline 3.2 Adverse events (any) & 21 & 7876 & Risk Difference (M-H, Random, 95\% Cl) & $0.13[0.08,0.18]$ \\
\hline 3.2.1 Almotriptan & 1 & 720 & Risk Difference (M-H, Random, 95\% Cl) & $0.05[0.00,0.09]$ \\
\hline 3.2.2 Eletriptan & 1 & 242 & Risk Difference (M-H, Random, 95\% Cl) & $0.14[0.02,0.26]$ \\
\hline 3.2.3 Naratriptan & 1 & 300 & Risk Difference (M-H, Random, 95\% Cl) & $0.16[0.05,0.27]$ \\
\hline 3.2.4 Rizatriptan & 4 & 1706 & Risk Difference (M-H, Random, 95\% Cl) & $0.04[-0.02,0.10]$ \\
\hline 3.2.5 Sumatriptan & 10 & 2969 & Risk Difference (M-H, Random, 95\% Cl) & $0.18[0.09,0.27]$ \\
\hline
\end{tabular}




\begin{tabular}{|c|c|c|c|c|}
\hline $\begin{array}{l}\text { Outcome or subgroup } \\
\text { title }\end{array}$ & No. of studies & $\begin{array}{l}\text { No. of partici- } \\
\text { pants }\end{array}$ & Statistical method & Effect size \\
\hline 3.3 Headache relief & 20 & 6182 & Risk Ratio (M-H, Random, 95\% Cl) & $1.14[1.04,1.24]$ \\
\hline 3.3.1 Almotriptan & 1 & 714 & Risk Ratio (M-H, Random, 95\% Cl) & $1.27[1.10,1.47]$ \\
\hline 3.3.2 Eletriptan & 1 & 277 & Risk Ratio (M-H, Random, 95\% Cl) & $0.96[0.79,1.17]$ \\
\hline 3.3.3 Naratriptan & 1 & 300 & Risk Ratio (M-H, Random, 95\% Cl) & $0.80[0.65,1.00]$ \\
\hline 3.3.4 Rizatriptan & 4 & 1526 & Risk Ratio (M-H, Random, 95\% Cl) & $1.24[0.99,1.56]$ \\
\hline 3.3.5 Sumatriptan & 10 & 2392 & Risk Ratio (M-H, Random, 95\% Cl) & $1.14[1.02,1.28]$ \\
\hline 3.3.6 Zolmitriptan & 3 & 973 & Risk Ratio (M-H, Random, 95\% Cl) & $1.21[0.87,1.69]$ \\
\hline 3.4 Rescue medication & 18 & 5066 & Risk Ratio (M-H, Random, 95\% Cl) & $0.79[0.72,0.87]$ \\
\hline 3.4.1 Almotriptan & 1 & 714 & Risk Ratio (M-H, Random, 95\% Cl) & $0.57[0.28,1.16]$ \\
\hline 3.4.2 Eletriptan & 1 & 277 & Risk Ratio (M-H, Random, 95\% Cl) & $0.82[0.59,1.12]$ \\
\hline 3.4.3 Naratriptan & 1 & 300 & Risk Ratio (M-H, Random, 95\% Cl) & $0.92[0.55,1.53]$ \\
\hline 3.4.4 Rizatriptan & 3 & 956 & Risk Ratio (M-H, Random, 95\% Cl) & $0.74[0.55,1.01]$ \\
\hline 3.4.6 Zolmitriptan & 2 & 368 & Risk Ratio (M-H, Random, 95\% Cl) & $0.55[0.20,1.52]$ \\
\hline $\begin{array}{l}\text { 3.5 Headache recur- } \\
\text { rence }\end{array}$ & 15 & 2463 & Risk Ratio (M-H, Random, 95\% Cl) & $0.79[0.68,0.93]$ \\
\hline 3.5.1 Almotriptan & 1 & 477 & Risk Ratio (M-H, Random, 95\% Cl) & $1.13[0.44,2.89]$ \\
\hline 3.5.2 Eletriptan & 1 & 161 & Risk Ratio (M-H, Random, 95\% Cl) & $0.81[0.53,1.23]$ \\
\hline 3.5.3 Naratriptan & 1 & 201 & Risk Ratio (M-H, Random, 95\% Cl) & $0.84[0.42,1.67]$ \\
\hline 3.5.4 Rizatriptan & 1 & 177 & Risk Ratio (M-H, Random, 95\% Cl) & $0.63[0.30,1.32]$ \\
\hline 3.5.5 Sumatriptan & 9 & 1319 & Risk Ratio (M-H, Random, 95\% Cl) & $0.78[0.65,0.94]$ \\
\hline 3.5.6 Zolmitriptan & 2 & 128 & Risk Ratio (M-H, Random, 95\% Cl) & $0.98[0.36,2.65]$ \\
\hline 3.6 Presence of nausea & 17 & 4975 & Risk Ratio (M-H, Random, 95\% Cl) & $0.94[0.79,1.12]$ \\
\hline 3.6.1 Almotriptan & 1 & 356 & Risk Ratio (M-H, Random, 95\% Cl) & $1.45[1.04,2.02]$ \\
\hline 3.6.2 Eletriptan & 1 & 277 & Risk Ratio (M-H, Random, 95\% Cl) & $0.96[0.84,1.09]$ \\
\hline 3.6.3 Naratriptan & 1 & 300 & Risk Ratio (M-H, Random, 95\% Cl) & $1.08[0.66,1.78]$ \\
\hline 3.6.4 Rizatriptan & 2 & 1060 & Risk Ratio (M-H, Random, 95\% Cl) & $0.63[0.49,0.80]$ \\
\hline
\end{tabular}




\begin{tabular}{|c|c|c|c|c|}
\hline $\begin{array}{l}\text { Outcome or subgroup } \\
\text { title }\end{array}$ & No. of studies & $\begin{array}{l}\text { No. of partici- } \\
\text { pants }\end{array}$ & Statistical method & Effect size \\
\hline 3.6.5 Sumatriptan & 10 & 2279 & Risk Ratio (M-H, Random, 95\% Cl) & $1.01[0.78,1.29]$ \\
\hline 3.6.6 Zolmitriptan & 2 & 703 & Risk Ratio (M-H, Random, 95\% Cl) & $0.39[0.04,4.02]$ \\
\hline $\begin{array}{l}3.7 \text { Presence of vomit- } \\
\text { ing }\end{array}$ & 12 & 4037 & Risk Ratio (M-H, Random, 95\% Cl) & $0.73[0.48,1.12]$ \\
\hline 3.7.1 Almotriptan & 0 & 0 & Risk Ratio (M-H, Random, 95\% Cl) & Not estimable \\
\hline 3.7.2 Eletriptan & 0 & 0 & Risk Ratio (M-H, Random, 95\% Cl) & Not estimable \\
\hline 3.7.3 Naratriptan & 1 & 300 & Risk Ratio (M-H, Random, 95\% Cl) & $1.96[0.24,16.05]$ \\
\hline 3.7.4 Rizatriptan & 1 & 769 & Risk Ratio (M-H, Random, 95\% Cl) & $0.51[0.22,1.18]$ \\
\hline 3.7.5 Sumatriptan & 8 & 2265 & Risk Ratio (M-H, Random, 95\% Cl) & $0.68[0.39,1.20]$ \\
\hline 3.7.6 Zolmitriptan & 2 & 703 & Risk Ratio (M-H, Random, 95\% Cl) & $1.12[0.79,1.58]$ \\
\hline
\end{tabular}


Analysis 3.1. Comparison 3: Triptans vs placebo in adolescents, Outcome 1: Pain-free

\begin{tabular}{lccccccc} 
& \multicolumn{2}{c}{ Triptan } & \multicolumn{2}{c}{ Placebo } & \multicolumn{2}{c}{ Risk Ratio } & Risk Ratio \\
Study or Subgroup & Events & Total & Events & Total & Weight & M-H, Random, 95\% CI & M-H, Random, 95\% CI
\end{tabular}

\subsubsection{Almotriptan}

Linder 2008

Subtotal (95\% CI)

Total events:

$212 \quad 544$

544

60

170

170

$10.6 \%$

212

60

Heterogeneity: Not applicable

Test for overall effect: $\mathrm{Z}=0.85(\mathrm{P}=0.40)$

\subsubsection{Eletriptan}

Winner 2007

Subtotal (95\% CI)

31

$$
\begin{aligned}
& 141 \\
& 141
\end{aligned}
$$

20

133

$3.6 \%$

Total events:

31

20

$3.6 \%$

Heterogeneity: Not applicable

Test for overall effect: $\mathrm{Z}=1.46(\mathrm{P}=0.14)$

\subsubsection{Naratriptan}

Rothner 1997

Subtotal (95\% CI)

$52 \quad 226$
226

Total events:

52

226

Heterogeneity: Not applicable

Test for overall effect: $\mathrm{Z}=0.25(\mathrm{P}=0.81)$

\subsubsection{Rizatriptan}

Ahonen 2006

Winner 2002

Ho 2012

Visser 2004a

Subtotal (95\% CI)

Total events:

Heterogeneity: $\mathrm{Tau}^{2}=0.01 ; \mathrm{Chi}^{2}=3.61$ df $=3(\mathrm{P}=0.31) ; \mathrm{I}^{2}=17 \%$

Test for overall effect: $\mathrm{Z}=3.28(\mathrm{P}=0.001)$

\subsubsection{Sumatriptan}

Hämäläinen 1997b

Rothner 1999b

Rothner 1999c

Callenbach 2007

Rothner 1999a

Fujita 2014

Ahonen 2004

Winner 1997

Winner 2000

Winner 2006

Subtotal (95\% CI)

Total events:

\section{4}

$48 \quad 149$

$87 \quad 284$

$\begin{array}{ll}87 & 284 \\ 91 & 233\end{array}$

\section{7}

40

62

96

142

$3.7 \%$

$6.4 \%$

$8.5 \%$

$240 \quad 9.8 \%$

$764 \quad 28.4 \%$

$$
194
$$

Heterogeneity: $\mathrm{Tau}^{2}=0.00 ; \mathrm{Chi}^{2}=8.94, \mathrm{df}=9(\mathrm{P}=0.44) ; \mathrm{I}^{2}=0 \%$

Test for overall effect: $\mathrm{Z}=3.15(\mathrm{P}=0.002)$

\subsubsection{Zolmitriptan}

Evers 2006

Lewis 2007

Rothner 2006

NCT01211145

Suhtotal (95\% r.I)

$\begin{array}{rrrrr}5 & 23 & 2 & 23 & 0.5 \% \\ 9 & 62 & 3 & 30 & 0.7 \% \\ 11 & 66 & 5 & 36 & 1.1 \% \\ 12 & 46 & 9 & 46 & 1.8 \% \\ 43 & 208 & 10 & 35 & 2.9 \% \\ 16 & 74 & 20 & 70 & 3.0 \% \\ 26 & 83 & 17 & 83 & 3.4 \% \\ 58 & 222 & 14 & 76 & 3.5 \% \\ 116 & 377 & 32 & 130 & 6.8 \% \\ 191 & 483 & 68 & 242 & 10.5 \% \\ & \mathbf{1 6 4 4} & & \mathbf{7 7 1} & \mathbf{3 4 . 3 \%}\end{array}$

$2.50[0.54,11.60]$

1.45 [0.42, 4.98]

$1.20[0.45,3.18]$

$1.33[0.62,2.86]$

$0.72[0.40,1.30]$

$0.76[0.43,1.34]$

$1.53[0.90,2.60]$

$1.42[0.84,2.39]$

$1.25[0.89,1.75]$

$1.41[1.12,1.77]$

$1.27[1.10,1.48]$

$6.00[0.83,43.59]$

2.07 [1.37, 3.13]

$1.13[0.80,1.61]$

$1.77[1.30,2.41]$

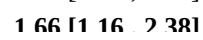


Analysis 3.1. (Continued)

\begin{tabular}{|c|c|c|c|c|c|}
\hline NCT01211145 & 86 & 288 & 50 & 296 & $7.6 \%$ \\
\hline Subtotal (95\% CI) & & 933 & & 599 & $19.3 \%$ \\
\hline Total events: & 258 & & 107 & & \\
\hline \multicolumn{6}{|c|}{ Heterogeneity: Tau $^{2}=0.07 ; \mathrm{Chi}^{2}=7.34, \mathrm{df}=3(\mathrm{P}=0.06) ; \mathrm{I}^{2}=59 \%$} \\
\hline \multicolumn{6}{|c|}{ Test for overall effect: $\mathrm{Z}=2.79(\mathrm{P}=0.005)$} \\
\hline Total (95\% CI) & & 4250 & & 2511 & $100.0 \%$ \\
\hline Total events: & 1300 & & 577 & & \\
\hline \multicolumn{6}{|c|}{ Heterogeneity: $\mathrm{Tau}^{2}=0.01 ; \mathrm{Chi}^{2}=27.11, \mathrm{df}=20(\mathrm{P}=0.13) ; \mathrm{I}^{2}=26 \%$} \\
\hline \multicolumn{6}{|c|}{ Test for overall effect: $\mathrm{Z}=5.11(\mathrm{P}<0.00001)$} \\
\hline Test for subgroup dif & $: \mathrm{Chi}^{2}=$ & $72, \mathrm{df}=$ & & & \\
\hline
\end{tabular}

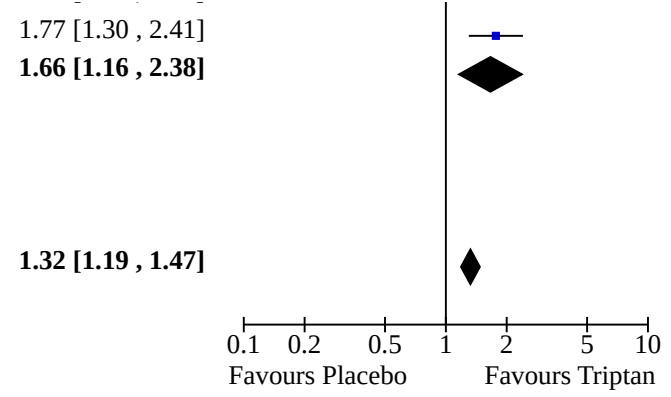


Analysis 3.2. Comparison 3: Triptans vs placebo in adolescents, Outcome 2: Adverse events (any)

\begin{tabular}{lccccccc} 
& \multicolumn{2}{c}{ Triptan } & \multicolumn{2}{c}{ Placebo } & \multicolumn{2}{c}{ Risk Difference } & Risk Difference \\
Study or Subgroup & Events & Total & Events & Total & Weight & M-H, Random, 95\% CI & M-H, Random, 95\% CI
\end{tabular}

3.2.1 Almotriptan

Linder 2008

Subtotal (95\% CI)

Total events:

$57 \quad 548$

548

10

172

$5.9 \%$

Heterogeneity: Not applicable

Test for overall effect: $Z=2.08(P=0.04)$

\subsubsection{Eletriptan}

Winner 2007

Subtotal $(95 \%$ CI)

55

129

Total events:

55

32

113

$4.5 \%$

Heterogeneity: Not applicable

Test for overall effect: $\mathrm{Z}=2.36(\mathrm{P}=0.02)$

\subsubsection{Naratriptan}

Rothner 1997

Subtotal (95\% CI)

76

226

226

Total events:

76

Heterogeneity: Not applicable

Test for overall effect: $\mathrm{Z}=2.96(\mathrm{P}=0.003)$

\subsubsection{Rizatriptan}

Winner 2002

Visser 2004a

Ahonen 2006

Ho 2012

Subtotal (95\% CI)

Total events:

Heterogeneity: $\mathrm{Tau}^{2}=0.00 ; \mathrm{Chi}^{2}=8.24, \mathrm{df}=3(\mathrm{P}=0.04) ; \mathrm{I}^{2}=64 \%$

Test for overall effect: $\mathrm{Z}=1.36(\mathrm{P}=0.17)$

\subsubsection{Sumatriptan}

Hämäläinen 1997b

Callenbach 2007

Rothner 1999b

Rothner 1999c

Fujita 2014

Ahonen 2004

Winner 2000

Rothner 1999a

Winner 1997

Winner 2006

Subtotal $(95 \%$ CI)

Total events:

$\begin{array}{ll}50 & 149 \\ 47 & 234 \\ 16 & 116 \\ 81 & 337 \\ & \mathbf{8 3 6}\end{array}$

\section{2}

147

242

$4.7 \%$

$5.5 \%$

$5.6 \%$

116

$5.6 \%$

$870 \quad 21.4 \%$

177

Heterogeneity: $\mathrm{Tau}^{2}=0.02 ; \mathrm{Chi}^{2}=63.26, \mathrm{df}=9(\mathrm{P}<0.00001) ; \mathrm{I}^{2}=86 \%$

Test for overall effect: $\mathrm{Z}=3.88(\mathrm{P}=0.0001)$

\subsubsection{Zolmitriptan}

Evers 2006

Lewis 2007

Rothner 2006

NCT01211145

Suhtotal (95\% r.I)

$\begin{array}{rrrrr}8 & 23 & 2 & 23 & 2.6 \% \\ 21 & 46 & 10 & 46 & 3.2 \% \\ 19 & 62 & 6 & 30 & 3.3 \% \\ 11 & 66 & 5 & 36 & 4.0 \% \\ 12 & 74 & 10 & 70 & 4.6 \% \\ 35 & 90 & 7 & 87 & 4.6 \% \\ 185 & 377 & 53 & 130 & 4.9 \% \\ 129 & 445 & 16 & 85 & 5.1 \% \\ 239 & 289 & 102 & 252 & 5.4 \% \\ 145 & 493 & 20 & 245 & 5.8 \% \\ & 1965 & & \mathbf{1 0 0 4} & \mathbf{4 3 . 5 \%} \\ 804 & & 231 & & \end{array}$

$2.6 \%$

$3.2 \%$

$4.0 \%$

$4.6 \%$

$4.6 \%$

$4.9 \%$

$5.4 \%$

$.8 \%$

$0.18[0.09,0.27]$

$0.26[0.03,0.49]$

0.24 [0.05, 0.43]

$0.11[-0.08,0.29]$

$0.03[-0.12,0.17]$

$0.02[-0.10,0.14]$

$0.08[-0.02,0.18]$

$0.10[0.01,0.19]$

$0.42[0.35,0.50]$

$0.21[0.16,0.27]$
$0.05[0.00,0.09]$

$0.05[0.00,0.09]$

$0.14[0.02,0.26]$

$0.14[0.02,0.26]$

$0.16[0.05,0.27]$

0.16 [0.05, 0.27]

$-0.02[-0.13,0.09]$

$0.04[-0.03,0.11]$

$0.12[0.05,0.19]$

$0.01[-0.05,0.08]$

$0.04[-0.02,0.10]$

$0.31[0.19,0.42]$

$0.21[-0.01,0.42]$

$0.08[0.01,0.15]$

$0.21[0.14,0.27]$

0.10 [0.05, 0.15]

ก 14 In ก7 n 201

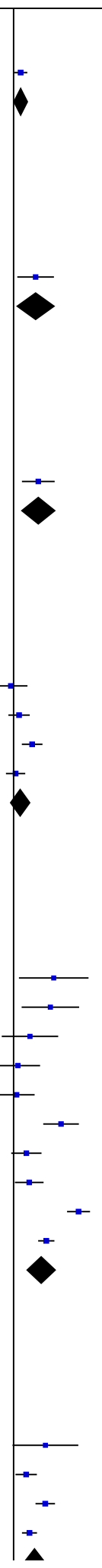


Analysis 3.2. (Continued)

NCT01211145

Subtotal (95\% CI)

Total events:

101

502

29

1254

321

Heterogeneity: $\mathrm{Tau}^{2}=0.00 ; \mathrm{Chi}^{2}=9.07, \mathrm{df}=3(\mathrm{P}=0.03) ; \mathrm{I}^{2}=67 \%$

Test for overall effect: $\mathrm{Z}=4.05(\mathrm{P}<0.0001)$

\section{Total $(95 \%$ CI)}

4958

Total events:

1507

$2918 \quad 100.0 \%$

Heterogeneity: $\mathrm{Tau}^{2}=0.01 ; \mathrm{Chi}^{2}=138.31, \mathrm{df}=20(\mathrm{P}<0.00001) ; \mathrm{I}^{2}=86 \%$

Test for overall effect: $\mathrm{Z}=5.33(\mathrm{P}<0.00001)$

Test for subgroup differences: $\mathrm{Chi}^{2}=14.26, \mathrm{df}=5(\mathrm{P}=0.01), \mathrm{I}^{2}=64.9 \%$
$0.10[0.05,0.15]$

$0.14[0.07,0.20]$

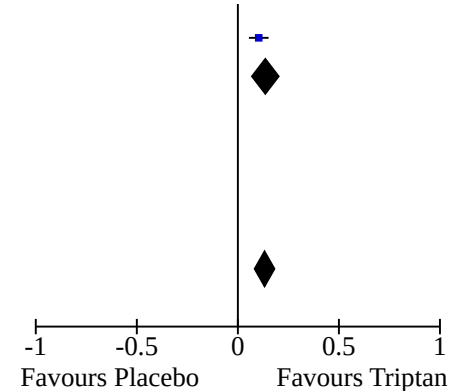


Analysis 3.3. Comparison 3: Triptans vs placebo in adolescents, Outcome 3: Headache relief

\begin{tabular}{lccccccc} 
& \multicolumn{2}{c}{ Triptan } & \multicolumn{2}{c}{ Placebo } & \multicolumn{2}{c}{ Risk Ratio } \\
Study or Subgroup & Events & Total & Events & Total & Weight & M-H, Random, 95\% CI \\
\hline 3.3.1 Almotriptan & & & & & & & \\
Linder 2008 & 383 & 544 & 94 & 170 & $7.5 \%$ & $1.27[1.10,1.47]$ \\
Subtotal (95\% CI) & & $\mathbf{5 4 4}$ & & $\mathbf{1 7 0}$ & $\mathbf{7 . 5 \%}$ & $\mathbf{1 . 2 7}[\mathbf{1 . 1 0}, \mathbf{1 . 4 7}]$ \\
Total events: & 383 & & 94 & & &
\end{tabular}

Heterogeneity: Not applicable

Test for overall effect: $\mathrm{Z}=3.25(\mathrm{P}=0.001)$

\subsubsection{Eletriptan}

Winner 2007

Subtotal (95\% CI)

$\begin{array}{lllll}82 & 144 & 79 & 133 & 6.4 \%\end{array}$

$0.96[0.79,1.17]$

Total events:

82

133

$6.4 \%$

Heterogeneity: Not applicable

Test for overall effect: $\mathrm{Z}=0.41(\mathrm{P}=0.68)$

\subsubsection{Naratriptan}

Rothner 1997

Subtotal (95\% CI)

Total events:

Heterogeneity: Not applicable

Test for overall effect: $\mathrm{Z}=1.94(\mathrm{P}=0.05)$

\subsubsection{Rizatriptan}

Ahonen 2006

Winner 2002

Ho 2012

Visser 2004a

Subtotal (95\% CI)

Total events:

Heterogeneity: Tau$^{2}=0.04 ; \mathrm{Chi}^{2}=20.70, \mathrm{df}=3(\mathrm{P}=0.0001) ; \mathrm{I}^{2}=86 \%$

Test for overall effect: $\mathrm{Z}=1.87(\mathrm{P}=0.06)$

\subsubsection{Sumatriptan}

Hämäläinen 1997b

Rothner 1999b

Callenbach 2007

Rothner 1999c

Fujita 2014

Ahonen 2004

Rothner 1999a

Winner 1997

Winner 2000

Winner 2006

Subtotal (95\% CI)

Total events:

$\begin{array}{rrrrr}71 & 96 & 35 & 96 & 4.8 \% \\ 98 & 149 & 80 & 142 & 6.7 \% \\ 167 & 284 & 147 & 286 & 7.4 \% \\ 159 & 233 & 165 & 240 & 7.9 \% \\ & \mathbf{7 6 2} & & \mathbf{7 6 4} & \mathbf{2 6 . 9 \%} \\ 495 & & 427 & & \end{array}$

$4.8 \%$

$6.7 \%$

$7.9 \%$

$6.9 \%$ 
Analysis 3.3. (Continued)

Subtotal (95\% CI)

Total events:

657 377 168

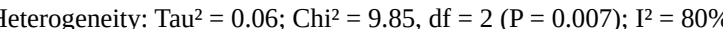

Test for overall effect: $\mathrm{Z}=1.16(\mathrm{P}=0.25)$

Total (95\% CI)

3955

$2227 \quad 100.0 \%$

Total events: 2358

1176

Heterogeneity: Tau $^{2}=0.02 ; \mathrm{Chi}^{2}=57.11, \mathrm{df}=19(\mathrm{P}<0.0001) ; \mathrm{I}^{2}=67 \%$

Test for overall effect: $\mathrm{Z}=2.70(\mathrm{P}=0.007)$

Test for subgroup differences: $\mathrm{Chi}^{2}=15.11$, $\mathrm{df}=5(\mathrm{P}=0.010), \mathrm{I}^{2}=66.9 \%$
$1.21[0.87,1.69]$

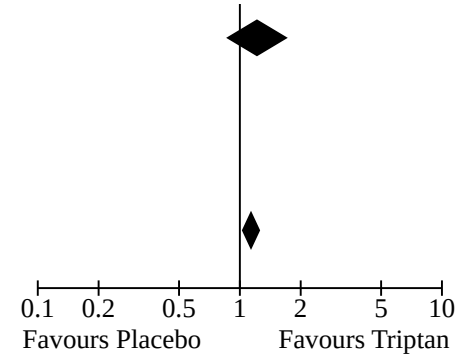


Analysis 3.4. Comparison 3: Triptans vs placebo in adolescents, Outcome 4: Rescue medication

\begin{tabular}{lccccccc} 
& \multicolumn{2}{c}{ Triptan } & \multicolumn{2}{c}{ Placebo } & \multicolumn{2}{c}{ Risk Ratio } & Risk Ratio \\
Study or Subgroup & Events & Total & Events & Total & Weight & M-H, Random, 95\% CI & M-H, Random, 95\% CI
\end{tabular}

\subsubsection{Almotriptan}

Linder 2008

Subtotal (95\% CI)

Total events:

544

11

170

$1.6 \%$

20

11

Heterogeneity: Not applicable

Test for overall effect: $\mathrm{Z}=1.55(\mathrm{P}=0.12)$

\subsubsection{Eletriptan}

Winner 2007

Subtotal (95\% CI)

Total events:

$46 \quad 144$

52

133

$8.1 \%$

Heterogeneity: Not applicable

46

144

52

$8.1 \%$

Test for overall effect: $\mathrm{Z}=1.24(\mathrm{P}=0.21)$

\subsubsection{Naratriptan}

Rothner 1997

Subtotal (95\% CI)

45

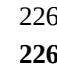

226

16

74

Total events:

45

Heterogeneity: Not applicable

Test for overall effect: $\mathrm{Z}=0.32(\mathrm{P}=0.75)$

\subsubsection{Rizatriptan}

Ahonen 2006

Winner 2002

Visser 2004a

Subtotal (95\% CI)

Total events:

Heterogeneity: $\mathrm{Tau}^{2}=0.05 ; \mathrm{Chi}^{2}=5.87, \mathrm{df}=2(\mathrm{P}=0.05) ; \mathrm{I}^{2}=66 \%$

Test for overall effect: $\mathrm{Z}=1.92(\mathrm{P}=0.05)$

3.4.5 Sumatriptan

Winner 1997

Hämäläinen 1997b

Fujita 2014

Rothner 1999c

Callenbach 2007

Rothner 1999a

Rothner 1999b

Ahonen 2004

Winner 2000

Winner 2006

Subtotal (95\% CI)

Total events:

\section{7}

58

84

96

149

233

478

$\begin{array}{rrr}38 & 96 & 3.3 \% \\ 65 & 142 & 11.3 \% \\ 101 & 240 & 16.0 \% \\ & \mathbf{4 7 8} & \mathbf{3 0 . 6 \%}\end{array}$
204
$0.57[0.28,1.16]$

$0.57[0.28,1.16]$

$0.82[0.59,1.12]$

$0.82[0.59,1.12]$

$0.92[0.55,1.53]$

$0.92[0.55,1.53]$

$0.45[0.27,0.74]$

$0.85[0.65,1.11]$

0.86 [0.68, 1.07]

$0.74[0.55,1.01]$

$0.46[0.10,1.99]$

$1.00[0.33,2.99]$

$1.05[0.45,2.43]$

0.97 [0.48, 1.97]

$0.87[0.47,1.61]$

$0.80[0.47,1.35]$

0.58 [0.34, 0.99]

$0.69[0.48,0.99]$

$0.69[0.51,0.94]$

$0.92[0.74,1.15]$

$0.80[0.70,0.92]$

Heterogeneity: $\mathrm{Tau}^{2}=0.00 ; \mathrm{Chi}^{2}=5.98, \mathrm{df}=9(\mathrm{P}=0.74) ; \mathrm{I}^{2}=0 \%$

Test for overall effect: $\mathrm{Z}=3.21(\mathrm{P}=0.001)$

\subsubsection{Zolmitriptan}

Evers 2006

Lewis 2007

Subtotal (95\% CI)

2

29
162
$\mathbf{1 9 1}$

8

29

$0.4 \%$

Total events:

64

177

$12.8 \%$

Heterogeneity: $\mathrm{Tau}^{2}=0.36 ; \mathrm{Chi}^{2}=2.25, \mathrm{df}=1(\mathrm{P}=0.13) ; \mathrm{I}^{2}=56 \%$

Tect for nverall effert $7=115(\mathrm{P}=025)$ 
Analysis 3.4. (Continued)

Heterogeneity: $\mathrm{Tau}^{2}=0.36 ; \mathrm{Chi}^{2}=2.25, \mathrm{df}=1(\mathrm{P}=0.13) ; \mathrm{I}^{2}=56 \%$ Test for overall effect: $\mathrm{Z}=1.15(\mathrm{P}=0.25)$

Total (95\% CI)

3255

$1811 \quad 100.0 \%$

$0.79[0.72,0.87]$

Total events:

718

599

Heterogeneity: $\mathrm{Tau}^{2}=0.00 ; \mathrm{Chi}^{2}=15.47, \mathrm{df}=17(\mathrm{P}=0.56) ; \mathrm{I}^{2}=0 \%$

Test for overall effect: $\mathrm{Z}=5.08(\mathrm{P}<0.00001)$

Test for subgroup differences: $\mathrm{Chi}^{2}=1.88, \mathrm{df}=5(\mathrm{P}=0.87), \mathrm{I}^{2}=0 \%$

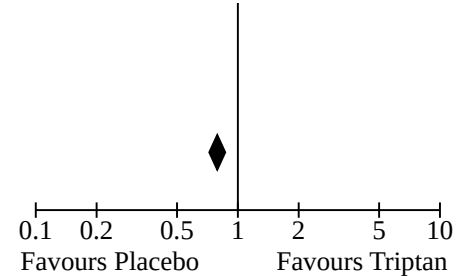


Analysis 3.5. Comparison 3: Triptans vs placebo in adolescents, Outcome 5: Headache recurrence

\begin{tabular}{|c|c|c|c|c|c|c|c|}
\hline \multirow[b]{2}{*}{ Study or Subgroup } & \multicolumn{2}{|c|}{ Triptan } & \multicolumn{2}{|c|}{ Placebo } & \multicolumn{2}{|r|}{ Risk Ratio } & Risk Ratio \\
\hline & Events & Total & Events & Total & Weight & M-H, Random, 95\% CI & M-H, Random, 95\% CI \\
\hline
\end{tabular}

\subsubsection{Almotriptan}

Linder 2008

Subtotal (95\% CI)

Total events:

$23 \quad 383$

383

23

Heterogeneity: Not applicable

Test for overall effect: $\mathrm{Z}=0.25(\mathrm{P}=0.80)$

\subsubsection{Eletriptan}

Winner 2007

Subtotal (95\% CI)

Total events:

26$$
82
$$

$79 \quad 14.2 \%$

Heterogeneity: Not applicable

Test for overall effect: $\mathrm{Z}=1.00(\mathrm{P}=0.32)$

\subsubsection{Naratriptan}

Rothner 1997

Subtotal (95\% CI)

24

Total events:

153

9

$48 \quad 5.2 \%$

24

Heterogeneity: Not applicable

Test for overall effect: $\mathrm{Z}=0.50(\mathrm{P}=0.61)$

\subsubsection{Rizatriptan}

Winner 2002

Subtotal (95\% CI)

Total events:

98
98

98
98

11

Heterogeneity: Not applicable

Test for overall effect: $\mathrm{Z}=1.22(\mathrm{P}=0.22)$

\subsubsection{Sumatriptan}

Hämäläinen 1997b

Callenbach 2007

Ahonen 2004

Winner 1997

Rothner 1999c

Winner 2000

Rothner 1999b

Rothner 1999a

Winner 2006

Subtotal (95\% CI)

Total events:

Heterogeneity: $\mathrm{Tau}^{2}=0.00 ; \mathrm{Chi}^{2}=2.08, \mathrm{df}=7(\mathrm{P}=0.96) ; \mathrm{I}^{2}=0 \%$

Test for overall effect: $\mathrm{Z}=2.57(\mathrm{P}=0.01)$

\subsubsection{Zolmitriptan}

Evers 2006

NCT01211145

Subtotal (95\% CI)

Total events:

$$
3
$$

5

$$
\begin{aligned}
& 14 \\
& 62
\end{aligned}
$$$$
2
$$

$0.9 \%$

$1.6 \%$

$2.5 \%$

8

Heterogeneity: $\mathrm{Tau}^{2}=0.00 ; \mathrm{Chi}^{2}=0.41, \mathrm{df}=1(\mathrm{P}=0.52) ; \mathrm{I}^{2}=0 \%$

Test for overall effect: $\mathrm{Z}=0.03(\mathrm{P}=0.97)$

Total (95\% CI)

1730

$3 \cap 6$

$733 \quad 100.0 \%$
$1.13[0.44,2.89]$

1.13 [0.44, 2.89]

$0.81[0.53,1.23]$

$0.81[0.53,1.23]$

$0.84[0.42,1.67]$

0.84 [0.42, 1.67]

$0.63[0.30,1.32]$

$0.63[0.30,1.32]$

Not estimable

$1.05[0.28,4.00]$

$0.60[0.16,2.25]$

$0.76[0.41,1.42]$

$1.07[0.59,1.95]$

$0.89[0.52,1.53]$

$0.71[0.44,1.13]$

$0.71[0.44,1.13]$

$0.75[0.54,1.05]$

$0.78[0.65,0.94]$

$1.50[0.29,7.65]$

$0.77[0.22,2.68]$

0.98 [0.36, 2.65]

$0.79[0.68,0.93]$ 
Analysis 3.5. (Continued)

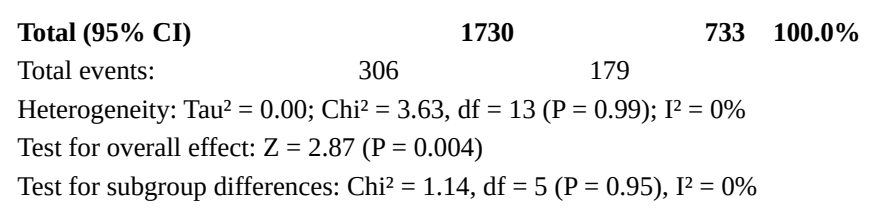

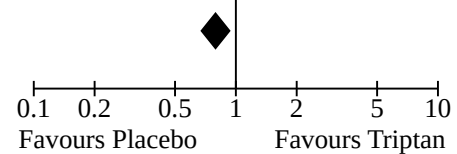


Analysis 3.6. Comparison 3: Triptans vs placebo in adolescents, Outcome 6: Presence of nausea

\begin{tabular}{|c|c|c|c|c|c|c|}
\hline \multirow[b]{2}{*}{ Study or Subgroup } & \multicolumn{2}{|c|}{ Triptan } & \multicolumn{2}{|c|}{ Placebo } & \multirow[b]{2}{*}{ Weight } & \multirow{2}{*}{$\begin{array}{c}\text { Risk Ratio } \\
\text { M-H, Random, 95\% CI }\end{array}$} \\
\hline & Events & Total & Events & Total & & \\
\hline \multicolumn{7}{|l|}{ 3.6.1 Almotriptan } \\
\hline Linder 2008 & 65 & 186 & 41 & 170 & $7.8 \%$ & $1.45[1.04,2.02$ \\
\hline Subtotal (95\% CI) & & 186 & & 170 & $7.8 \%$ & $1.45[1.04,2$. \\
\hline Total events: & 65 & & 41 & & & \\
\hline
\end{tabular}

Heterogeneity: Not applicable

Test for overall effect: $Z=2.20(P=0.03)$

\subsubsection{Eletriptan}

Winner 2007

Subtotal (95\% CI)

$\begin{array}{lllll}108 & 144 & 104 & 133 & 10.0 \%\end{array}$

Total events:

$108 \quad 104$

$133 \quad 10.0 \%$

Heterogeneity: Not applicable

Test for overall effect: $\mathrm{Z}=0.63(\mathrm{P}=0.53)$

\subsubsection{Naratriptan}

Rothner 1997

Subtotal (95\% CI)

Total events:

Heterogeneity: Not applicable

Test for overall effect: $\mathrm{Z}=0.32(\mathrm{P}=0.75)$

\begin{tabular}{|c|c|c|c|c|c|}
\hline \multicolumn{6}{|l|}{ 3.6.4 Rizatriptan } \\
\hline Winner 2002 & 33 & 149 & 50 & 142 & $7.2 \%$ \\
\hline Ho 2012 & 52 & 381 & 85 & 388 & $8.0 \%$ \\
\hline Subtotal (95\% CI) & & 530 & & 530 & $15.2 \%$ \\
\hline Total events: & 85 & & 135 & & \\
\hline \multicolumn{6}{|c|}{ Heterogeneity: $\mathrm{Tau}^{2}=0.00 ; \mathrm{Chi}^{2}=0.00, \mathrm{df}=1(\mathrm{P}=0.97) ; \mathrm{I}^{2}=0 \%$} \\
\hline \multicolumn{6}{|c|}{ Test for overall effect: $\mathrm{Z}=3.82(\mathrm{P}=0.0001)$} \\
\hline \multicolumn{6}{|l|}{ 3.6.5 Sumatriptan } \\
\hline Ueberall 1999 & 3 & 14 & 8 & 14 & $2.1 \%$ \\
\hline Fujita 2014 & 7 & 18 & 4 & 21 & $2.2 \%$ \\
\hline Rothner 1999a & 80 & 232 & 7 & 41 & $4.0 \%$ \\
\hline Rothner 1999c & 28 & 66 & 8 & 36 & $4.2 \%$ \\
\hline Callenbach 2007 & 12 & 46 & 18 & 46 & $4.8 \%$ \\
\hline Rothner 1999b & 32 & 62 & 13 & 30 & $6.0 \%$ \\
\hline Hämäläinen 2002 & 20 & 59 & 29 & 58 & $6.4 \%$ \\
\hline Winner 1997 & 80 & 222 & 23 & 76 & $7.1 \%$ \\
\hline Winner 2000 & 73 & 377 & 33 & 130 & $7.4 \%$ \\
\hline Winner 2006 & 87 & 487 & 48 & 244 & $7.9 \%$ \\
\hline Subtotal (95\% CI) & & 1583 & & 696 & $52.2 \%$ \\
\hline Total events: & 422 & & 191 & & \\
\hline
\end{tabular}

Heterogeneity: $\mathrm{Tau}^{2}=0.08 ; \mathrm{Chi}^{2}=20.73, \mathrm{df}=9(\mathrm{P}=0.01) ; \mathrm{I}^{2}=57 \%$ Test for overall effect: $\mathrm{Z}=0.04(\mathrm{P}=0.97)$

\subsubsection{Zolmitriptan}

$\begin{array}{lrrrrr}\text { Evers 2006 } & 2 & 29 & 18 & 29 & 1.5 \% \\ \text { Rothner 2006 } & 108 & 483 & 32 & 162 & 7.5 \% \\ \text { Subtotal (95\% CI) } & & \mathbf{5 1 2} & & \mathbf{1 9 1} & \mathbf{9 . 0 \%} \\ \text { Total events: } & 110 & & 50 & & \end{array}$

Heterogeneity: Tau $^{2}=2.60 ; \mathrm{Chi}^{2}=11.02, \mathrm{df}=1(\mathrm{P}=0.0009) ; \mathrm{I}^{2}=91 \%$

Test for overall effect: $\mathrm{Z}=0.79(\mathrm{P}=0.43)$
$0.96[0.84,1.09]$

$0.63[0.43,0.91]$ $0.62[0.45,0.85]$ $0.63[0.49,0.80]$

$0.38[0.12,1.13]$ $2.04[0.71,5.86]$ $2.02[1.01,4.06]$ 1.91 [0.97, 3.74] $0.67[0.36,1.22]$ $1.19[0.74,1.92]$ $0.68[0.44,1.05]$ $1.19[0.81,1.75]$ $0.76[0.53,1.09]$ $0.91[0.66,1.25]$ $1.01[0.78,1.29]$

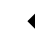

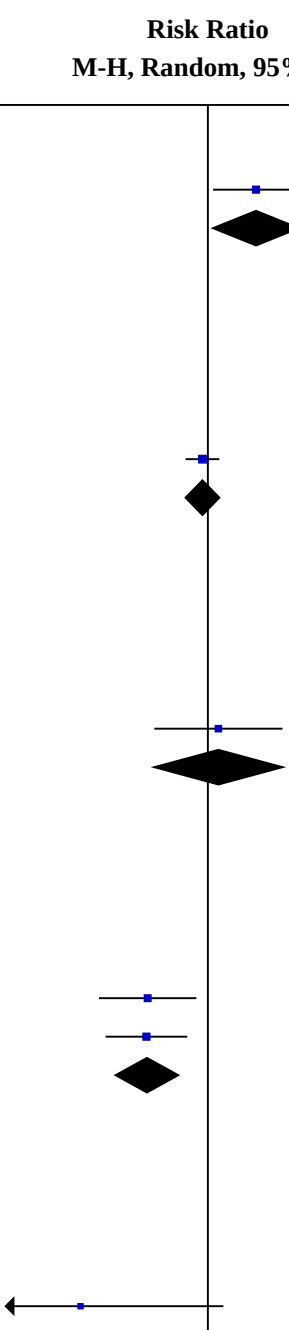

0.11 [0.03, 0.44] $1.13[0.80,1.61]$ 0.39 [0.04, 4.02]

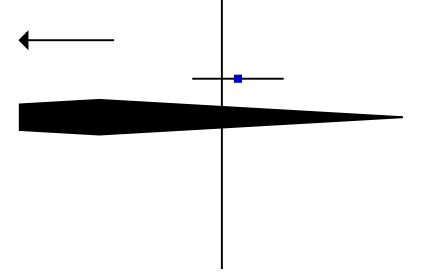


Analysis 3.6. (Continued)

Test for overall effect: $\mathrm{Z}=0.79(\mathrm{P}=0.43)$

\section{Total (95\% CI)}

Total events: 843

Heterogeneity: $\mathrm{Tau}^{2}=0.08 ; \mathrm{Chi}^{2}=49.30, \mathrm{df}=16(\mathrm{P}<0.0001) ; \mathrm{I}^{2}=68 \%$

Test for overall effect: $\mathrm{Z}=0.69(\mathrm{P}=0.49)$

Test for subgroup differences: $\mathrm{Chi}^{2}=18.77$, $\mathrm{df}=5(\mathrm{P}=0.002), \mathrm{I}^{2}=73.4 \%$

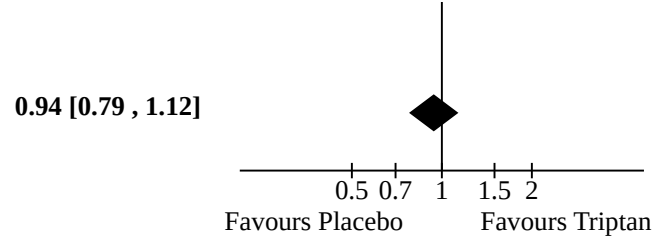


Analysis 3.7. Comparison 3: Triptans vs placebo in adolescents, Outcome 7: Presence of vomiting

\begin{tabular}{lcccccc} 
& \multicolumn{2}{c}{ Triptan } & \multicolumn{2}{c}{ Placebo } & Risk Ratio & Risk Ratio \\
Study or Subgroup & Events & Total & Events $\quad$ Total & Weight & M-H, Random, 95\% CI & M-H, Random, 95\% CI
\end{tabular}

3.7.1 Almotriptan

Subtotal (95\% CI)

$\mathbf{0}$

Total events:

0

$\mathbf{0}$

Heterogeneity: Not applicable

Test for overall effect: Not applicable

\subsubsection{Eletriptan}

Subtotal (95\% CI)

0

Total events:

0

Heterogeneity: Not applicable

Test for overall effect: Not applicable

\subsubsection{Naratriptan}

Rothner 1997

Subtotal (95\% CI)

Total events:

Heterogeneity: Not applicable

Test for overall effect: $\mathrm{Z}=0.63(\mathrm{P}=0.53)$

\subsubsection{Rizatriptan}

Ho 2012

Subtotal (95\% CI)

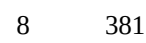

381

16

388

$11.1 \%$

$3.4 \%$

Total events:

8

388

$11.1 \%$

Heterogeneity: Not applicable

Test for overall effect: $\mathrm{Z}=1.58(\mathrm{P}=0.11)$

\subsubsection{Sumatriptan}

Winner 2000

Ueberall 1999

Rothner 1999c

Rothner 1999b

Winner 1997

Rothner 1999c

Rothner 1999a

Winner 2006

Winner 2000

Hämäläinen 2002

Subtotal (95\% CI)

Total events:

$\begin{array}{rr}4 & 18 \\ 0 & 14 \\ 7 & 66 \\ 5 & 62 \\ 3 & 222 \\ 5 & 46 \\ 10 & 232 \\ 7 & 487 \\ 21 & 377 \\ 11 & 59 \\ & \mathbf{1 5 8 3}\end{array}$

Heterogeneity: $\mathrm{Tau}^{2}=0.34 ; \mathrm{Chi}^{2}=16.93, \mathrm{df}=9(\mathrm{P}=0.05) ; \mathrm{I}^{2}=47 \%$

Test for overall effect: $\mathrm{Z}=1.32(\mathrm{P}=0.19)$

\subsubsection{Zolmitriptan}

Evers 2006

Rothner 2006

\section{0}

Subtotal (95\% CI)

108

483

Total events:

108

512

Heterogeneity: $\mathrm{Tau}^{2}=0.00 ; \mathrm{Chi}^{2}=0.57, \mathrm{df}=1(\mathrm{P}=0.45) ; \mathrm{I}^{2}=0 \%$

Test for overall effect: $\mathrm{Z}=0.61(\mathrm{P}=0.54)$

\section{Total (95\% CI)}

2702

$1335 \quad 100.0 \%$

Total events:

195

112

Heternoeneitv Tal1 $\left.^{2}=n\right) \Delta \cdot \Gamma \mathrm{hi}^{2}=351 \mathrm{ndf}=12(\mathrm{P}=\mathrm{n} \Omega) \cdot \mathrm{I}^{2}=\Delta 8 \%$
$1.96[0.24,16.05]$

Not estimable

Not estimable $1.96[0.24,16.05]$

$0.51[0.22,1.18]$ $0.51[0.22,1.18]$

$3.79[0.23,62.47]$ $0.08[0.00,1.25]$ $3.82[0.49,29.82]$ $1.21[0.25,5.88]$ $0.21[0.05,0.84]$ $1.67[0.42,6.57]$ $0.59[0.17,2.05]$ $0.44[0.16,1.19]$ $1.21[0.50,2.92]$ $0.39[0.21,0.70]$ $0.68[0.39,1.20]$

$0.33[0.01,7.86]$ $1.13[0.80,1.61]$ $1.12[0.79,1.58]$

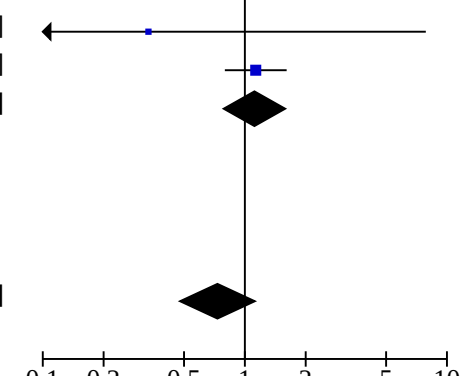




\section{Analysis 3.7. (Continued)}

Total events: $195 \quad 112$

Heterogeneity: Tau$^{2}=0.24 ; \mathrm{Chi}^{2}=25.10, \mathrm{df}=13(\mathrm{P}=0.02) ; \mathrm{I}^{2}=48 \%$

Test for overall effect: $\mathrm{Z}=1.44(\mathrm{P}=0.15)$

Test for subgroup differences: $\mathrm{Chi}^{2}=4.64, \mathrm{df}=3(\mathrm{P}=0.20), \mathrm{I}^{2}=35.4 \%$

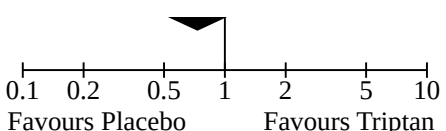

Favours Placebo Favours Triptan

\section{Comparison 4. Triptans vs placebo in adolescents, subgroup analysis}

\begin{tabular}{|c|c|c|c|c|}
\hline Outcome or subgroup title & No. of studies & $\begin{array}{l}\text { No. of partici- } \\
\text { pants }\end{array}$ & Statistical method & Effect size \\
\hline $\begin{array}{l}4.1 \text { Pain-free by route (oral or } \\
\text { intranasal) }\end{array}$ & 21 & 6764 & Risk Ratio (M-H, Random, 95\% Cl) & $1.32[1.19,1.47]$ \\
\hline 4.1.1 Oral & 15 & 4415 & Risk Ratio (M-H, Random, 95\% Cl) & $1.22[1.08,1.38]$ \\
\hline 4.1.2 Intranasal & 6 & 2349 & Risk Ratio (M-H, Random, 95\% Cl) & $1.52[1.32,1.75]$ \\
\hline $\begin{array}{l}4.2 \text { Sumatriptan vs placebo by } \\
\text { route (oral or intranasal) }\end{array}$ & 10 & 2415 & Risk Ratio (M-H, Random, 95\% Cl) & $1.27[1.10,1.48]$ \\
\hline 4.2.1 Intranasal & 4 & 1490 & Risk Ratio (M-H, Random, 95\% Cl) & $1.37[1.15,1.63]$ \\
\hline 4.2.2 Oral & 6 & 925 & Risk Ratio (M-H, Random, 95\% Cl) & $1.03[0.75,1.43]$ \\
\hline $\begin{array}{l}4.3 \text { Zolmitriptan vs placebo by } \\
\text { route (oral or intranasal) }\end{array}$ & 4 & 1532 & Risk Ratio (M-H, Random, 95\% Cl) & $1.66[1.16,2.38]$ \\
\hline 4.3.1 Intranasal & 2 & 859 & Risk Ratio (M-H, Random, 95\% Cl) & $1.87[1.46,2.40]$ \\
\hline 4.3.2 Oral & 2 & 673 & Risk Ratio (M-H, Random, 95\% Cl) & $1.94[0.42,9.07]$ \\
\hline $\begin{array}{l}\text { 4.4 Pain-free by preventive } \\
\text { medication }\end{array}$ & 21 & 6764 & Risk Ratio (M-H, Random, 95\% Cl) & $1.32[1.19,1.47]$ \\
\hline $\begin{array}{l}\text { 4.4.1 Preventive medication } \\
\text { not permitted }\end{array}$ & 8 & 1658 & Risk Ratio (M-H, Random, 95\% Cl) & $1.39[1.14,1.69]$ \\
\hline $\begin{array}{l}\text { 4.4.2 Preventive medication } \\
\text { permitted }\end{array}$ & 8 & 2316 & Risk Ratio (M-H, Random, 95\% Cl) & $1.28[1.04,1.56]$ \\
\hline 4.4.3 Unsure & 5 & 2790 & Risk Ratio $(\mathrm{M}-\mathrm{H}$, Random, 95\% Cl) & $1.33[1.11,1.61]$ \\
\hline
\end{tabular}


Analysis 4.1. Comparison 4: Triptans vs placebo in adolescents, subgroup analysis, Outcome 1: Pain-free by route (oral or intranasal)

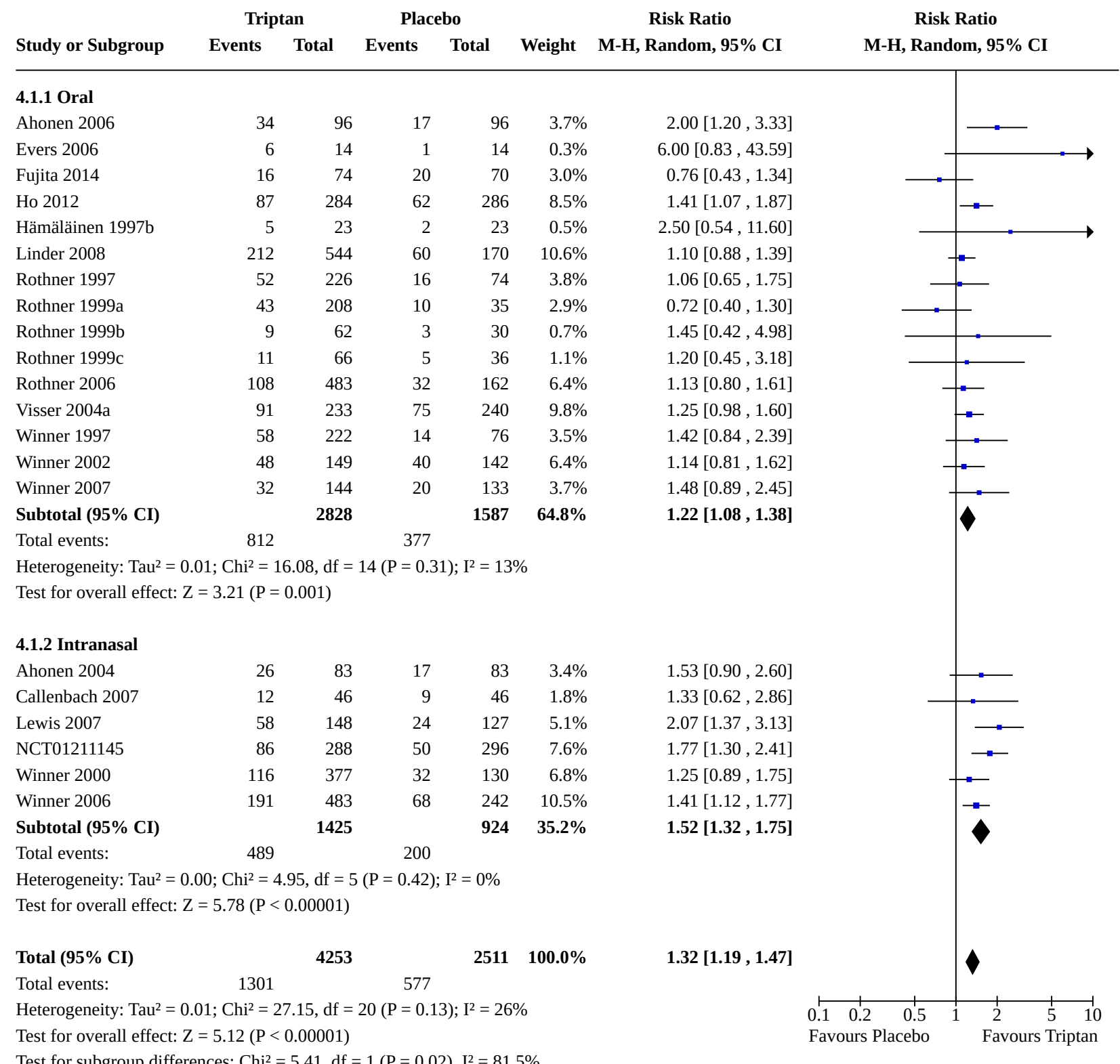


Analysis 4.2. Comparison 4: Triptans vs placebo in adolescents, subgroup analysis, Outcome 2: Sumatriptan vs placebo by route (oral or intranasal)

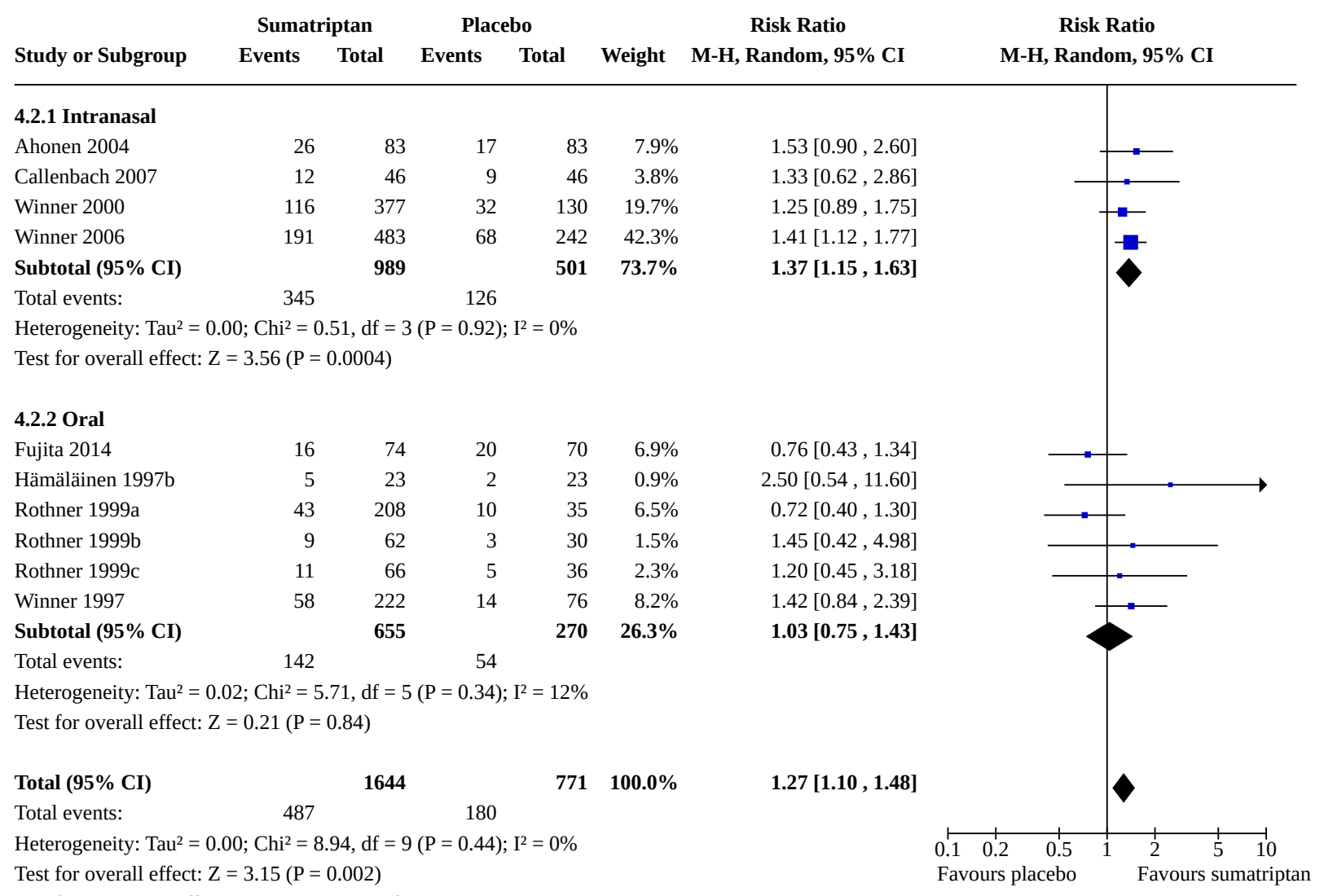


Analysis 4.3. Comparison 4: Triptans vs placebo in adolescents, subgroup analysis, Outcome 3: Zolmitriptan vs placebo by route (oral or intranasal)

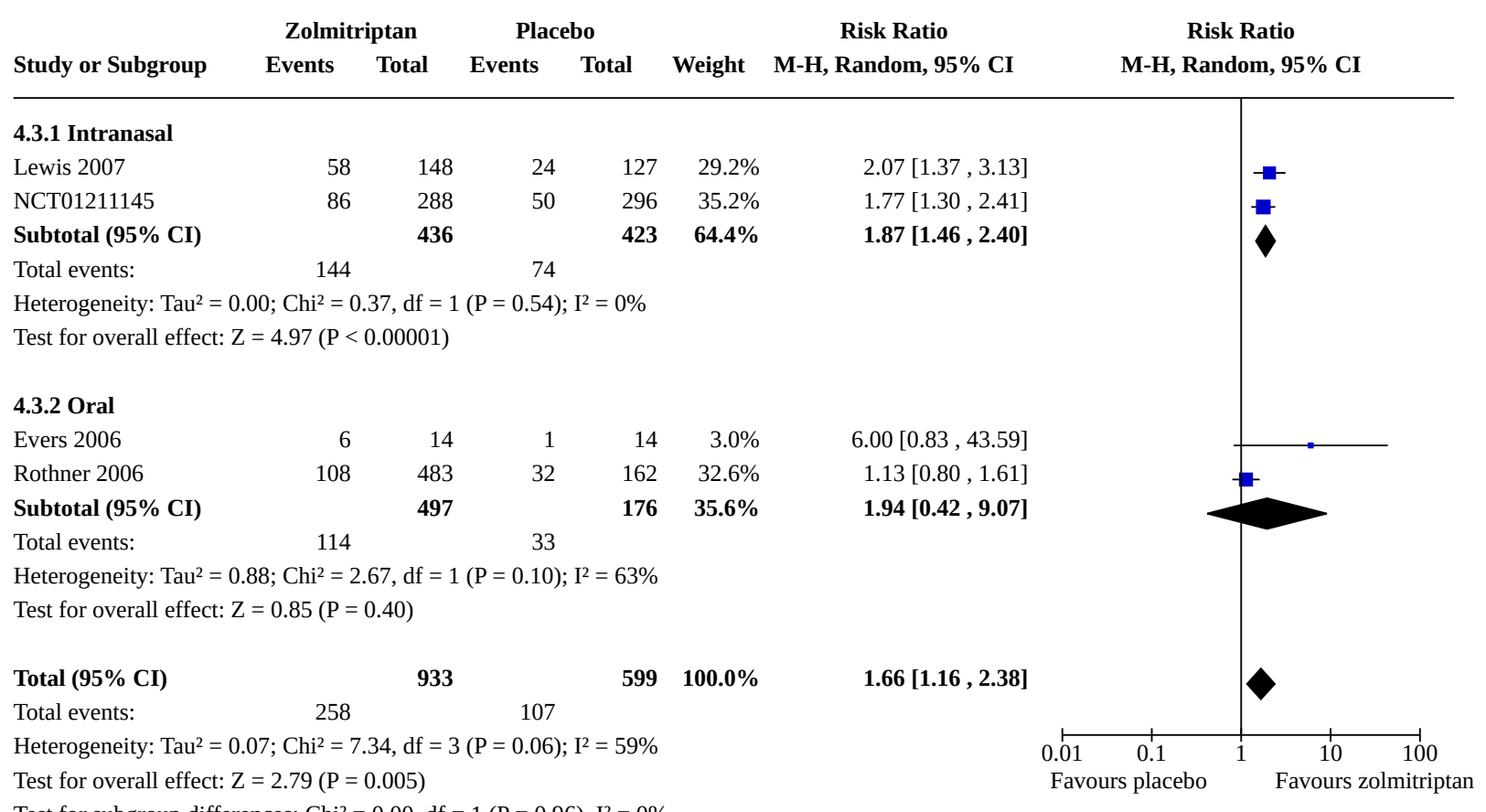


Analysis 4.4. Comparison 4: Triptans vs placebo in adolescents, subgroup analysis, Outcome 4: Pain-free by preventive medication

\begin{tabular}{|c|c|c|c|c|c|c|c|c|}
\hline \multirow[b]{2}{*}{ Study or Subgroup } & \multicolumn{2}{|c|}{ Triptan } & \multicolumn{2}{|c|}{ Placebo } & \multirow[b]{2}{*}{ Weight } & \multirow{2}{*}{$\begin{array}{c}\text { Risk Ratio } \\
\text { M-H, Random, 95\% CI }\end{array}$} & \multirow{2}{*}{\multicolumn{2}{|c|}{$\begin{array}{c}\text { Risk Ratio } \\
\text { M-H, Random, 95\% CI }\end{array}$}} \\
\hline & Events & Total & Events & Total & & & & \\
\hline \multicolumn{9}{|c|}{ 4.4.1 Preventive medication not permitted } \\
\hline Hämäläinen 1997b & 5 & 23 & 2 & 23 & $0.5 \%$ & $2.50[0.54,11.60]$ & & $\rightarrow$ \\
\hline Rothner 1999b & 9 & 62 & 3 & 30 & $0.7 \%$ & $1.45[0.42,4.98]$ & & \\
\hline Rothner 1999c & 11 & 66 & 5 & 36 & $1.1 \%$ & $1.20[0.45,3.18]$ & & \\
\hline Callenbach 2007 & 12 & 46 & 9 & 46 & $1.8 \%$ & $1.33[0.62,2.86]$ & & \\
\hline Rothner 1999a & 43 & 208 & 10 & 35 & $2.9 \%$ & $0.72[0.40,1.30]$ & & - \\
\hline Ahonen 2004 & 26 & 83 & 17 & 83 & $3.4 \%$ & $1.53[0.90,2.60]$ & & \\
\hline Ahonen 2006 & 34 & 96 & 17 & 96 & $3.7 \%$ & $2.00[1.20,3.33]$ & & \\
\hline Winner 2006 & 191 & 483 & 68 & 242 & $10.5 \%$ & $1.41[1.12,1.77]$ & & $\rightarrow$ \\
\hline Subtotal (95\% CI) & & 1067 & & 591 & $24.6 \%$ & $1.39[1.14,1.69]$ & & \\
\hline Total events: & 331 & & 131 & & & & & \\
\hline \multicolumn{9}{|c|}{ Heterogeneity: $\mathrm{Tau}^{2}=0.01 ; \mathrm{Chi}^{2}=7.52, \mathrm{df}=7(\mathrm{P}=0.38) ; \mathrm{I}^{2}=7 \%$} \\
\hline \multicolumn{9}{|c|}{ Test for overall effect: $\mathrm{Z}=3.32(\mathrm{P}=0.0009)$} \\
\hline \multicolumn{9}{|c|}{ 4.4.2 Preventive medication permitted } \\
\hline Evers 2006 & 6 & 14 & 1 & 14 & $0.3 \%$ & $6.00[0.83,43.59]$ & & $\longrightarrow$ \\
\hline Fujita 2014 & 16 & 74 & 20 & 70 & $3.0 \%$ & $0.76[0.43,1.34]$ & & - \\
\hline Winner 1997 & 58 & 222 & 14 & 76 & $3.5 \%$ & $1.42[0.84,2.39]$ & & \\
\hline Rothner 1997 & 52 & 226 & 16 & 74 & $3.8 \%$ & $1.06[0.65,1.75]$ & & 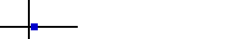 \\
\hline Lewis 2007 & 58 & 148 & 24 & 127 & $5.1 \%$ & $2.07[1.37,3.13]$ & & 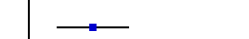 \\
\hline Winner 2002 & 48 & 149 & 40 & 142 & $6.4 \%$ & $1.14[0.81,1.62]$ & & \\
\hline Winner 2000 & 116 & 377 & 32 & 130 & $6.8 \%$ & $1.25[0.89,1.75]$ & & \\
\hline Visser 2004a & 91 & 233 & 75 & 240 & $9.8 \%$ & $1.25[0.98,1.60]$ & & \\
\hline Subtotal (95\% CI) & & 1443 & & 873 & $38.7 \%$ & $1.28[1.04,1.56]$ & & \\
\hline Total events: & 445 & & 222 & & & & & \\
\hline \multicolumn{9}{|c|}{ Heterogeneity: $\mathrm{Tau}^{2}=0.03 ; \mathrm{Chi}^{2}=12.02, \mathrm{df}=7(\mathrm{P}=0.10) ; \mathrm{I}^{2}=42 \%$} \\
\hline \multicolumn{9}{|c|}{ Test for overall effect: $\mathrm{Z}=2.38(\mathrm{P}=0.02)$} \\
\hline \multicolumn{9}{|l|}{ 4.4.3 Unsure } \\
\hline Winner 2007 & 32 & 144 & 20 & 133 & $3.7 \%$ & $1.48[0.89,2.45]$ & & \\
\hline Rothner 2006 & 108 & 483 & 32 & 162 & $6.4 \%$ & $1.13[0.80,1.61]$ & & $t=$ \\
\hline NCT01211145 & 86 & 288 & 50 & 296 & $7.6 \%$ & $1.77[1.30,2.41]$ & & $\rightarrow$ \\
\hline Но 2012 & 87 & 284 & 62 & 286 & $8.5 \%$ & $1.41[1.07,1.87]$ & & $\rightarrow$ \\
\hline Linder 2008 & 212 & 544 & 60 & 170 & $10.6 \%$ & $1.10[0.88,1.39]$ & & - \\
\hline Subtotal $(95 \% \mathrm{CI})$ & & 1743 & & 1047 & $36.7 \%$ & $1.33[1.11,1.61]$ & & \\
\hline Total events: & 525 & & 224 & & & & & \\
\hline \multicolumn{9}{|c|}{ Heterogeneity: $\mathrm{Tau}^{2}=0.02 ; \mathrm{Chi}^{2}=6.95, \mathrm{df}=4(\mathrm{P}=0.14) ; \mathrm{I}^{2}=42 \%$} \\
\hline \multicolumn{9}{|c|}{ Test for overall effect: $\mathrm{Z}=3.04(\mathrm{P}=0.002)$} \\
\hline Total (95\% CI) & & 4253 & & 2511 & $100.0 \%$ & $1.32[1.19,1.47]$ & & $\Delta$ \\
\hline Total events: & 1301 & & 577 & & & & & \\
\hline \multicolumn{7}{|c|}{ Heterogeneity: $\mathrm{Tau}^{2}=0.01 ; \mathrm{Chi}^{2}=27.15, \mathrm{df}=20(\mathrm{P}=0.13) ; \mathrm{I}^{2}=26 \%$} & $0.1 \quad 0.2 \quad 0.5$ & $\begin{array}{lll}1 & 5 & 10\end{array}$ \\
\hline \multicolumn{7}{|c|}{ Test for overall effect: $\mathrm{Z}=5.12(\mathrm{P}<0.00001)$} & Favours Placebo & Favours Triptan \\
\hline
\end{tabular}

Test for subgroup differences: $\mathrm{Chi}^{2}=0.37, \mathrm{df}=2(\mathrm{P}=0.83), \mathrm{I}^{2}=0 \%$

Comparison 5. Triptans vs placebo by age, subgroup analysis

\begin{tabular}{lllll}
\hline $\begin{array}{l}\text { Outcome or subgroup ti- } \\
\text { tle }\end{array}$ & No. of studies & $\begin{array}{l}\text { No. of partici- } \\
\text { pants }\end{array}$ & Statistical method & Effect size \\
\hline 5.1 Age group & 23 & Risk Ratio (M-H, Random, 95\% Cl) & Subtotals only \\
\hline
\end{tabular}




\begin{tabular}{lllll}
\hline $\begin{array}{l}\text { Outcome or subgroup ti- } \\
\text { tle }\end{array}$ & No. of studies & $\begin{array}{l}\text { No. of partici- } \\
\text { pants }\end{array}$ & Statistical method & Effect size \\
\hline 5.1 .1 Children & 3 & 345 & Risk Ratio (M-H, Random, 95\% Cl) & $1.67[1.06,2.62]$ \\
\hline $\begin{array}{l}\text { 5.1.2 Mixed children and } \\
\text { adolescents }\end{array}$ & 5 & 606 & Risk Ratio (M-H, Random, 95\% Cl) & $1.69[0.96,2.98]$ \\
\hline 5.1 .3 Adolescent & 16 & 6188 & Risk Ratio (M-H, Random, 95\% Cl) & $1.31[1.18,1.45]$ \\
\hline
\end{tabular}


Analysis 5.1. Comparison 5: Triptans vs placebo by age, subgroup analysis, Outcome 1: Age group
Triptan
Control
Risk Ratio
Risk Ratio

Study or Subgroup Events Total Events Total Weight $\quad$ M-H, Random, 95\% CI $\quad$ M-H, Random, 95\% CI

\begin{tabular}{lrrrrr}
\hline 5.1.1 Children & & & & & \\
Ho 2012 & 39 & 98 & 31 & 102 & $50.9 \%$ \\
Hämäläinen 2002 & 27 & 59 & 15 & 58 & $39.1 \%$ \\
Ueberall 1999 & 9 & 14 & 2 & 14 & $10.0 \%$ \\
Subtotal (95\% CI) & & $\mathbf{1 7 1}$ & & $\mathbf{1 7 4}$ & $\mathbf{1 0 0 . 0 \%}$ \\
Total events: & 75 & & 48 & &
\end{tabular}

Total events:

75

48

Heterogeneity: $\mathrm{Tau}^{2}=0.07 ; \mathrm{Chi}^{2}=3.47, \mathrm{df}=2(\mathrm{P}=0.18) ; \mathrm{I}^{2}=42 \%$

Test for overall effect: $\mathrm{Z}=2.21(\mathrm{P}=0.03)$

5.1.2 Mixed children and adolescents

$\begin{array}{lrrrrr}\text { Ahonen 2004 } & 26 & 83 & 17 & 83 & 26.5 \% \\ \text { Ahonen 2006 } & 34 & 96 & 17 & 96 & 27.0 \% \\ \text { Evers 2006 } & 13 & 29 & 2 & 29 & 11.1 \% \\ \text { Fujita 2014 } & 16 & 74 & 20 & 70 & 25.6 \% \\ \text { Hämäläinen 1997b } & 5 & 23 & 2 & 23 & 9.8 \% \\ \text { Subtotal (95\% CI) } & & \mathbf{3 0 5} & & \mathbf{3 0 1} & \mathbf{1 0 0 . 0 \%} \\ \text { Total events: } & 94 & & 58 & & \end{array}$

$1.53[0.90,2.60]$

$2.00[1.20,3.33]$

$6.50[1.61,26.28]$

$0.76[0.43,1.34]$

$2.50[0.54,11.60]$

$1.69[0.96,2.98]$

Heterogeneity: Tau $^{2}=0.24 ; \mathrm{Chi}^{2}=11.57, \mathrm{df}=4(\mathrm{P}=0.02) ; \mathrm{I}^{2}=65 \%$

Test for overall effect: $\mathrm{Z}=1.82(\mathrm{P}=0.07)$

\subsubsection{Adolescent}

Callenbach 2007

Ho 2012

Lewis 2007

Linder 2008

NCT01211145

Rothner 1997

Rothner 1999a

Rothner 1999b

Rothner 1999c

Rothner 2006

Visser 2004a

Winner 1997

Winner 2000

Winner 2002

Winner 2006

Winner 2007

Subtotal (95\% CI)

Total events:

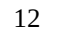

87

58

46

284

148

544

212

$86 \quad 288$

$52 \quad 226$

$43 \quad 208$

$9 \quad 62$

$11 \quad 66$

$108 \quad 483$

91233

$58 \quad 222$

$116 \quad 377$

$48 \quad 149$

191483

$32 \quad 144$

3963

1214

Heterogeneity: $\mathrm{Tau}^{2}=0.01 ; \mathrm{Chi}^{2}=17.64, \mathrm{df}=15(\mathrm{P}=0.28) ; \mathrm{I}^{2}=15 \%$

Test for overall effect: $\mathrm{Z}=5.24(\mathrm{P}<0.00001)$

Test for subgroup differences: $\mathrm{Chi}^{2}=1.76, \mathrm{df}=2(\mathrm{P}=0.42), \mathrm{I}^{2}=0 \%$
$1.31[0.89,1.92]$

$1.77[1.06,2.97]$

$1.67[1.06,2.62]$
$1.33[0.62,2.86]$

$1.41[1.07,1.87]$

$2.07[1.37,3.13]$

$1.10[0.88,1.39]$

1.77 [1.30, 2.41]

$1.06[0.65,1.75]$

$0.72[0.40,1.30]$

1.45 [0.42, 4.98]

1.20 [0.45, 3.18]

$1.13[0.80,1.61]$

$1.25[0.98,1.60]$

$1.42[0.84,2.39]$

$1.25[0.89,1.75]$

$1.14[0.81,1.62]$

$1.41[1.12,1.77]$

$1.48[0.89,2.45]$

1.31 [1.18, 1.45]
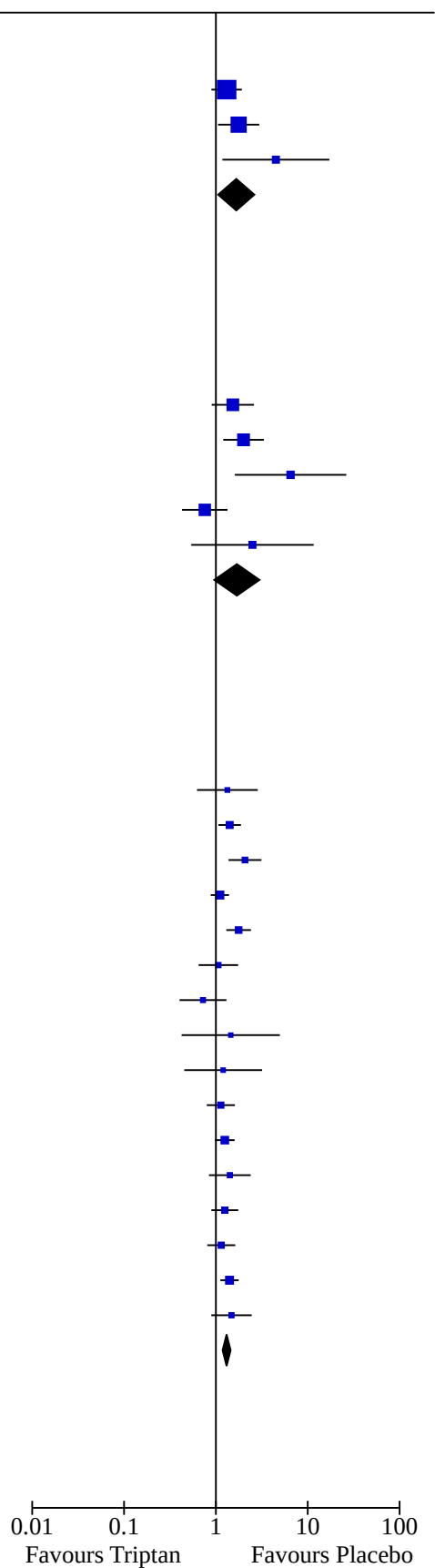

Comparison 6. Triptans vs placebo in adolescents, sensitivity analysis

\begin{tabular}{lllll}
\hline $\begin{array}{l}\text { Outcome or subgroup } \\
\text { title }\end{array}$ & No. of studies & $\begin{array}{l}\text { No. of partici- } \\
\text { pants }\end{array}$ & Statistical method & Effect size \\
\hline 6.1 Study design & 21 & 6794 & Risk Ratio (M-H, Random, 95\% Cl) & $1.33[1.19,1.49]$ \\
\hline
\end{tabular}




\begin{tabular}{|c|c|c|c|c|}
\hline $\begin{array}{l}\text { Outcome or subgroup } \\
\text { title }\end{array}$ & No. of studies & $\begin{array}{l}\text { No. of partici- } \\
\text { pants }\end{array}$ & Statistical method & Effect size \\
\hline 6.1.1 Cross-over & 7 & 1127 & Risk Ratio (M-H, Random, 95\% Cl) & $1.81[1.44,2.26]$ \\
\hline 6.1.2 Parallel & 14 & 5667 & Risk Ratio (M-H, Random, 95\% Cl) & $1.25[1.12,1.39]$ \\
\hline $\begin{array}{l}\text { 6.2 Allocation conceal- } \\
\text { ment }\end{array}$ & 21 & & Risk Ratio (M-H, Random, 95\% Cl) & Subtotals only \\
\hline 6.2.1 Low & 8 & 2365 & Risk Ratio (M-H, Random, 95\% Cl) & $1.50[1.19,1.89]$ \\
\hline 6.2.2 Unclear & 13 & 4429 & Risk Ratio (M-H, Random, 95\% Cl) & $1.25[1.12,1.40]$ \\
\hline 6.3 Source of funding & 21 & & Risk Ratio (M-H, Random, 95\% Cl) & Subtotals only \\
\hline 6.3.1 Pharmaceutical & 17 & 6332 & Risk Ratio (M-H, Random, 95\% Cl) & $1.29[1.16,1.43]$ \\
\hline $\begin{array}{l}\text { 6.3.2 Non-pharmaceuti- } \\
\text { cal }\end{array}$ & 2 & 104 & Risk Ratio (M-H, Random, 95\% Cl) & $4.22[1.50,11.84]$ \\
\hline 6.3.3 Unclear & 2 & 358 & Risk Ratio (M-H, Random, 95\% Cl) & $1.76[1.22,2.54]$ \\
\hline 6.4 Reported in a journal & 21 & & Risk Ratio (M-H, Random, 95\% Cl) & Subtotals only \\
\hline 6.4.1 Journal report & 15 & 5175 & Risk Ratio (M-H, Random, 95\% Cl) & $1.34[1.18,1.52]$ \\
\hline $\begin{array}{l}\text { 6.4.2 Registry or abstract } \\
\text { only }\end{array}$ & 6 & 1619 & Risk Ratio (M-H, Random, 95\% Cl) & $1.26[0.94,1.71]$ \\
\hline 6.5 Sample size & 21 & 6794 & Risk Ratio (M-H, Random, 95\% Cl) & $1.33[1.19,1.49]$ \\
\hline 6.5.1 Sample size $\leq 50$ & 2 & 104 & Risk Ratio (M-H, Random, 95\% Cl) & $4.22[1.50,11.84]$ \\
\hline 6.5.2 Sample size > 50 & 19 & 6690 & Risk Ratio (M-H, Random, 95\% Cl) & $1.31[1.18,1.46]$ \\
\hline
\end{tabular}


Analysis 6.1. Comparison 6: Triptans vs placebo in adolescents, sensitivity analysis, Outcome 1: Study design

\begin{tabular}{|c|c|c|c|c|c|c|c|c|}
\hline \multirow{3}{*}{$\begin{array}{l}\text { Study or Subgroup } \\
\text { 6.1.1 Cross-over }\end{array}$} & \multicolumn{2}{|c|}{ Triptan } & \multicolumn{2}{|c|}{ Control } & \multirow{3}{*}{ Weight } & \multirow{3}{*}{$\begin{array}{c}\text { Risk Ratio } \\
\text { M-H, Random, 95\% CI }\end{array}$} & \multirow{2}{*}{\multicolumn{2}{|c|}{$\begin{array}{c}\text { Risk Ratio } \\
\text { M-H, Random, 95\% CI }\end{array}$}} \\
\hline & Events & Total & Events & Total & & & & \\
\hline & & & & & & & & \\
\hline Ahonen 2004 & 26 & 83 & 17 & 83 & $3.6 \%$ & $1.53[0.90,2.60]$ & & 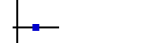 \\
\hline Ahonen 2006 & 34 & 96 & 17 & 96 & $3.8 \%$ & $2.00[1.20,3.33]$ & & $\rightarrow$ \\
\hline Callenbach 2007 & 12 & 46 & 9 & 46 & $2.0 \%$ & $1.33[0.62,2.86]$ & & $=$ \\
\hline Evers 2006 & 13 & 29 & 2 & 29 & $0.6 \%$ & $6.50[1.61,26.28]$ & & $\longrightarrow$ \\
\hline Hämäläinen 1997b & 5 & 23 & 2 & 23 & $0.5 \%$ & $2.50[0.54,11.60]$ & & $\longrightarrow$ \\
\hline Lewis 2007 & 58 & 148 & 24 & 127 & $5.2 \%$ & $2.07[1.37,3.13]$ & & $=$ \\
\hline Winner 1997 & 58 & 222 & 14 & 76 & $3.7 \%$ & $1.42[0.84,2.39]$ & & $=$ \\
\hline Subtotal $(95 \% \mathrm{CI})$ & & 647 & & 480 & $19.5 \%$ & $1.81[1.44,2.26]$ & & $\theta$ \\
\hline Total events: & 206 & & 85 & & & & & \\
\hline \multicolumn{9}{|c|}{ Heterogeneity: $\mathrm{Tau}^{2}=0.00 ; \mathrm{Chi}^{2}=5.84, \mathrm{df}=6(\mathrm{P}=0.44) ; \mathrm{I}^{2}=0 \%$} \\
\hline \multicolumn{9}{|c|}{ Test for overall effect: $\mathrm{Z}=5.13(\mathrm{P}<0.00001)$} \\
\hline \multicolumn{9}{|l|}{ 6.1.2 Parallel } \\
\hline Fujita 2014 & 16 & 74 & 20 & 70 & $3.2 \%$ & $0.76[0.43,1.34]$ & & - \\
\hline Ho 2012 & 87 & 284 & 62 & 286 & $8.2 \%$ & $1.41[1.07,1.87]$ & & - \\
\hline Linder 2008 & 212 & 544 & 60 & 170 & $9.9 \%$ & $1.10[0.88,1.39]$ & & + \\
\hline NCT01211145 & 86 & 288 & 50 & 296 & $7.5 \%$ & $1.77[1.30,2.41]$ & & - \\
\hline Rothner 1997 & 52 & 226 & 16 & 74 & $4.0 \%$ & $1.06[0.65,1.75]$ & & - \\
\hline Rothner 1999a & 43 & 208 & 10 & 35 & $3.1 \%$ & $0.72[0.40,1.30]$ & & $t$ \\
\hline Rothner 1999b & 9 & 62 & 3 & 30 & $0.8 \%$ & $1.45[0.42,4.98]$ & & $\rightarrow$ \\
\hline Rothner 1999c & 11 & 66 & 5 & 36 & $1.3 \%$ & $1.20[0.45,3.18]$ & & 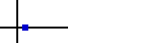 \\
\hline Rothner 2006 & 108 & 483 & 32 & 162 & $6.4 \%$ & $1.13[0.80,1.61]$ & & 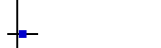 \\
\hline Visser 2004a & 91 & 233 & 75 & 240 & $9.3 \%$ & $1.25[0.98,1.60]$ & & - \\
\hline Winner 2000 & 116 & 377 & 32 & 130 & $6.8 \%$ & $1.25[0.89,1.75]$ & & - \\
\hline Winner 2002 & 48 & 149 & 40 & 142 & $6.4 \%$ & $1.14[0.81,1.62]$ & & + \\
\hline Winner 2006 & 191 & 483 & 68 & 242 & $9.9 \%$ & $1.41[1.12,1.77]$ & & - \\
\hline Winner 2007 & 32 & 144 & 20 & 133 & $3.9 \%$ & $1.48[0.89,2.45]$ & & $t=$ \\
\hline Subtotal $(95 \% \mathrm{CI})$ & & 3621 & & 2046 & $80.5 \%$ & $1.25[1.12,1.39]$ & & 1 \\
\hline Total events: & 1102 & & 493 & & & & & \\
\hline \multicolumn{9}{|c|}{ Heterogeneity: $\mathrm{Tau}^{2}=0.01 ; \mathrm{Chi}^{2}=15.48, \mathrm{df}=13(\mathrm{P}=0.28) ; \mathrm{I}^{2}=16 \%$} \\
\hline \multicolumn{9}{|c|}{ Test for overall effect: $\mathrm{Z}=4.16(\mathrm{P}<0.0001)$} \\
\hline Total $(95 \%$ CI $)$ & & 4268 & & 2526 & $100.0 \%$ & $1.33[1.19,1.49]$ & & 1 \\
\hline Total events: & 1308 & & 578 & & & & & \\
\hline \multicolumn{7}{|c|}{ Heterogeneity: $\mathrm{Tau}^{2}=0.02 ; \mathrm{Chi}^{2}=29.96, \mathrm{df}=20(\mathrm{P}=0.07) ; \mathrm{I}^{2}=33 \%$} & $0.01 \quad 0.1$ & 10 \\
\hline Test for overall effect: & $=4.92(\mathrm{P}<$ & $0.00001)$ & & & & & Favours Triptan & Favours $\mathrm{F}$ \\
\hline
\end{tabular}




\section{Analysis 6.2. Comparison 6: Triptans vs placebo in adolescents, sensitivity analysis, Outcome 2: Allocation concealment}

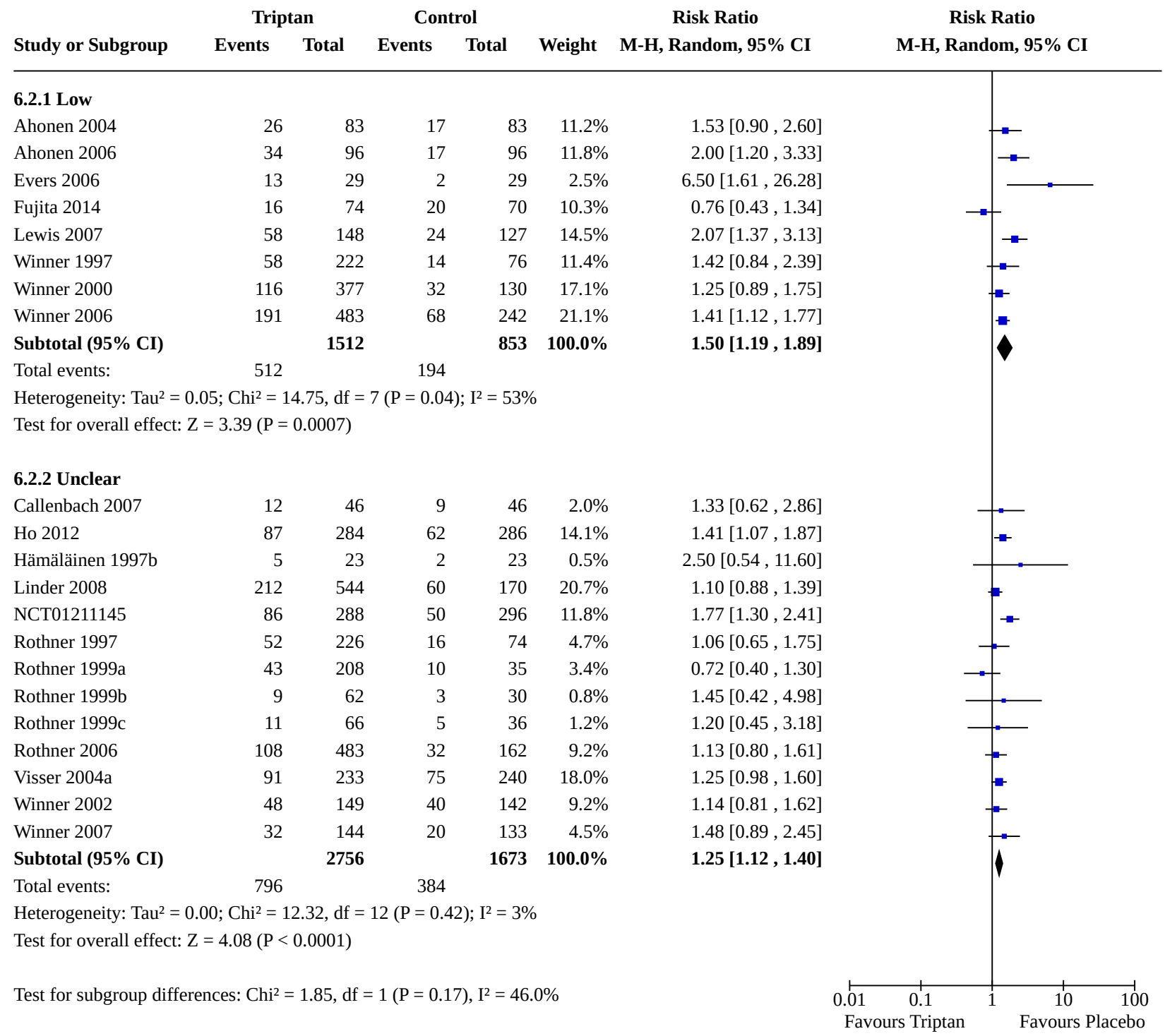


Analysis 6.3. Comparison 6: Triptans vs placebo in adolescents, sensitivity analysis, Outcome 3: Source of funding

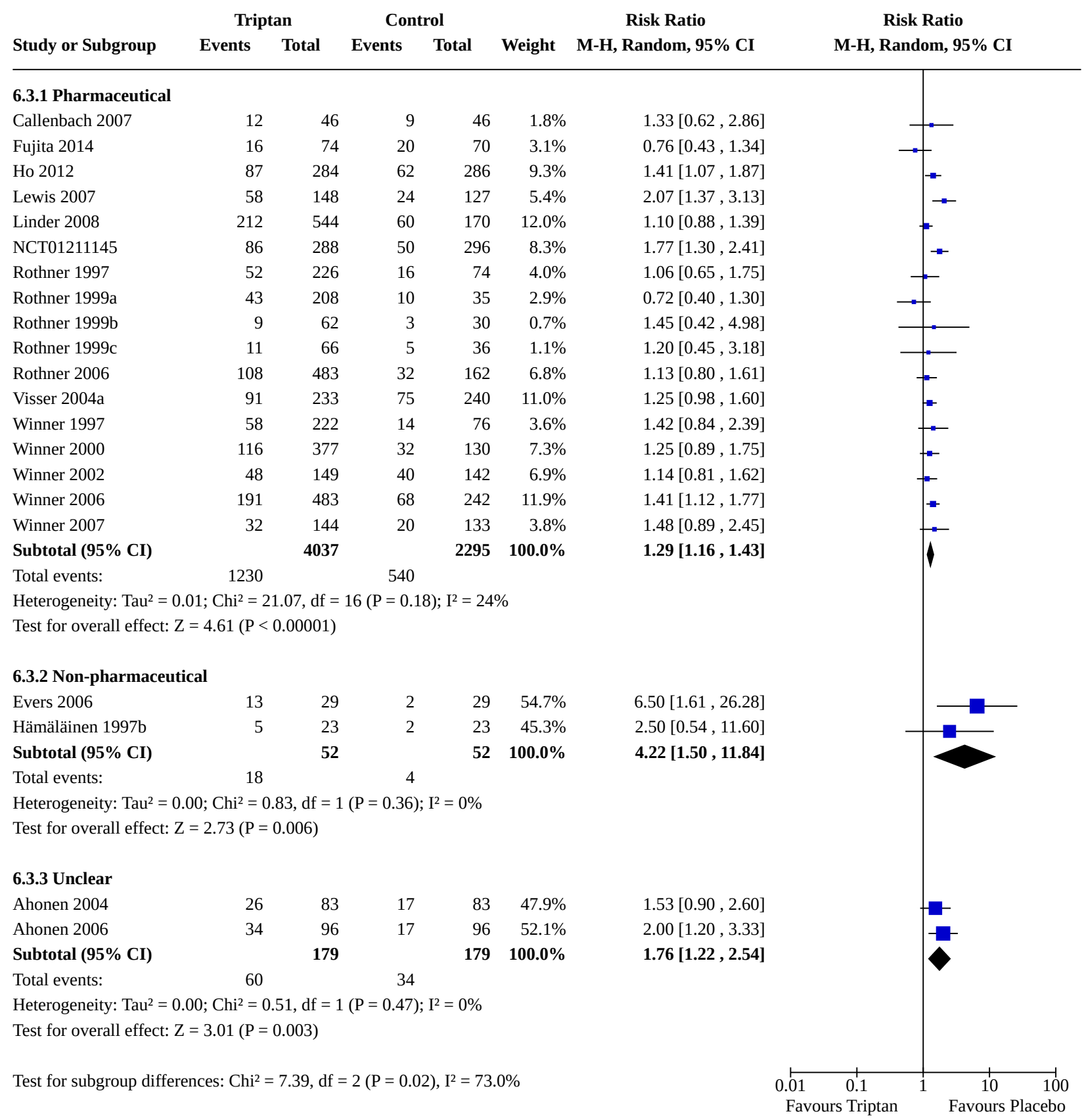




\section{Analysis 6.4. Comparison 6: Triptans vs placebo in adolescents, sensitivity analysis, Outcome 4: Reported in a journal}

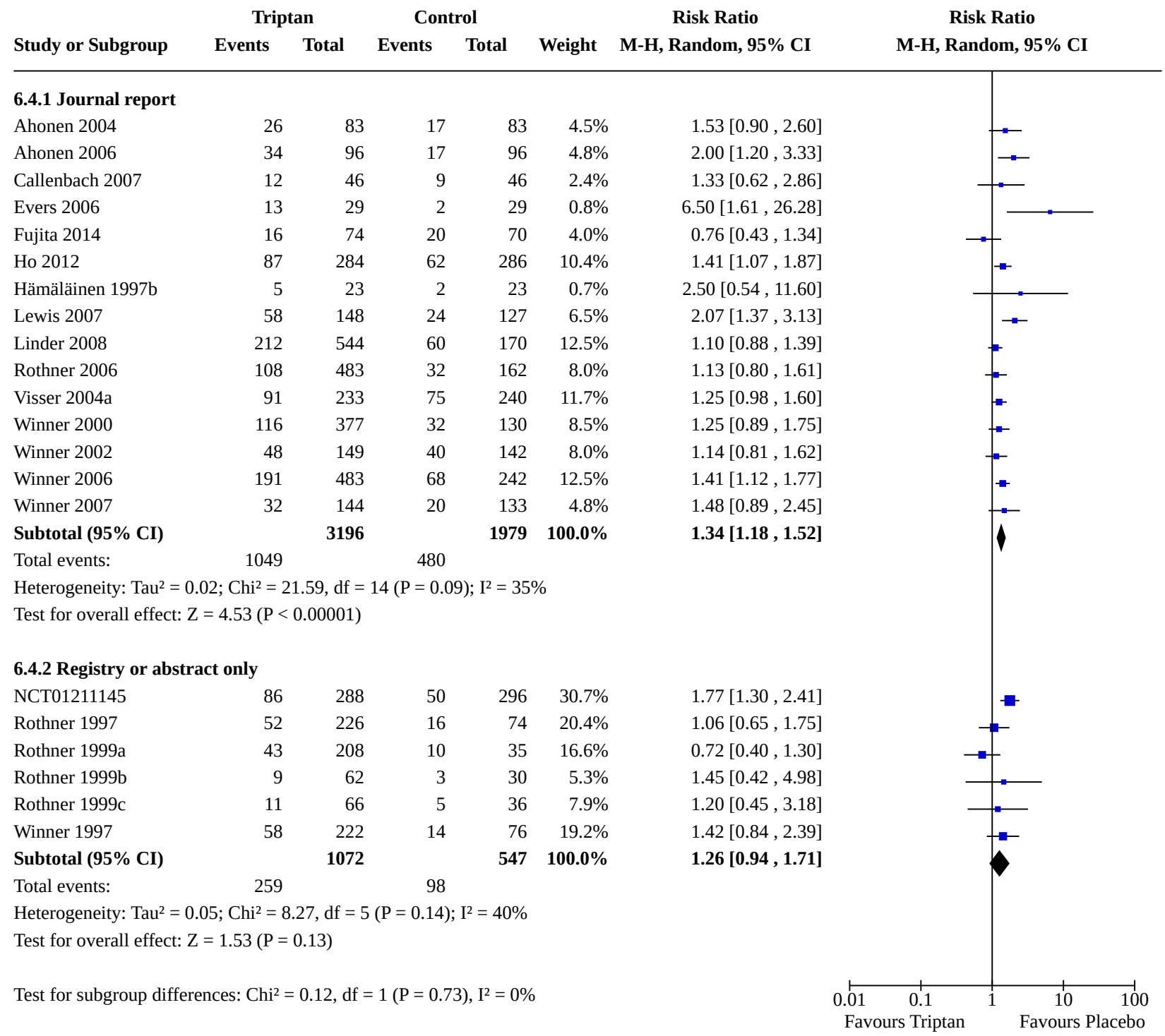


Analysis 6.5. Comparison 6: Triptans vs placebo in adolescents, sensitivity analysis, Outcome 5: Sample size

\begin{tabular}{|c|c|c|c|c|c|c|c|c|}
\hline \multirow[b]{2}{*}{ Study or Subgroup } & \multicolumn{2}{|c|}{ Triptan } & \multicolumn{2}{|c|}{ Control } & \multirow[b]{2}{*}{ Weight } & \multirow{2}{*}{$\begin{array}{c}\text { Risk Ratio } \\
\text { M-H, Random, 95\% CI }\end{array}$} & \multirow{2}{*}{\multicolumn{2}{|c|}{$\begin{array}{c}\text { Risk Ratio } \\
\text { M-H, Random, 95\% CI }\end{array}$}} \\
\hline & Events & Total & Events & Total & & & & \\
\hline \multicolumn{9}{|l|}{ 6.5.1 Sample size $\leq 50$} \\
\hline Evers 2006 & 13 & 29 & 2 & 29 & $0.6 \%$ & $6.50[1.61,26.28]$ & & $\longrightarrow$ \\
\hline Hämäläinen 1997b & 5 & 23 & 2 & 23 & $0.5 \%$ & $2.50[0.54,11.60]$ & & \\
\hline Subtotal $(95 \% \mathrm{CI})$ & & 52 & & 52 & $1.2 \%$ & $4.22[1.50,11.84]$ & & \\
\hline Total events: & 18 & & 4 & & & & & \\
\hline \multicolumn{9}{|c|}{ Heterogeneity: $\mathrm{Tau}^{2}=0.00 ; \mathrm{Chi}^{2}=0.83, \mathrm{df}=1(\mathrm{P}=0.36) ; \mathrm{I}^{2}=0 \%$} \\
\hline \multicolumn{9}{|c|}{ Test for overall effect: $\mathrm{Z}=2.73(\mathrm{P}=0.006)$} \\
\hline \multicolumn{9}{|l|}{ 6.5.2 Sample size > 50} \\
\hline Ahonen 2004 & 26 & 83 & 17 & 83 & $3.6 \%$ & $1.53[0.90,2.60]$ & & $G=$ \\
\hline Ahonen 2006 & 34 & 96 & 17 & 96 & $3.8 \%$ & $2.00[1.20,3.33]$ & & $=$ \\
\hline Callenbach 2007 & 12 & 46 & 9 & 46 & $2.0 \%$ & $1.33[0.62,2.86]$ & & $=$ \\
\hline Fujita 2014 & 16 & 74 & 20 & 70 & $3.2 \%$ & $0.76[0.43,1.34]$ & & + \\
\hline Ho 2012 & 87 & 284 & 62 & 286 & $8.2 \%$ & $1.41[1.07,1.87]$ & & - \\
\hline Lewis 2007 & 58 & 148 & 24 & 127 & $5.2 \%$ & $2.07[1.37,3.13]$ & & $\rightarrow$ \\
\hline Linder 2008 & 212 & 544 & 60 & 170 & $9.9 \%$ & $1.10[0.88,1.39]$ & & + \\
\hline NCT01211145 & 86 & 288 & 50 & 296 & $7.5 \%$ & $1.77[1.30,2.41]$ & & - \\
\hline Rothner 1997 & 52 & 226 & 16 & 74 & $4.0 \%$ & $1.06[0.65,1.75]$ & & - \\
\hline Rothner 1999a & 43 & 208 & 10 & 35 & $3.1 \%$ & $0.72[0.40,1.30]$ & & - \\
\hline Rothner 1999b & 9 & 62 & 3 & 30 & $0.8 \%$ & $1.45[0.42,4.98]$ & & 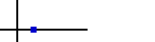 \\
\hline Rothner 1999c & 11 & 66 & 5 & 36 & $1.3 \%$ & $1.20[0.45,3.18]$ & & 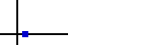 \\
\hline Rothner 2006 & 108 & 483 & 32 & 162 & $6.4 \%$ & $1.13[0.80,1.61]$ & & 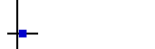 \\
\hline Visser 2004a & 91 & 233 & 75 & 240 & $9.3 \%$ & $1.25[0.98,1.60]$ & & 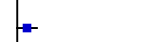 \\
\hline Winner 1997 & 58 & 222 & 14 & 76 & $3.7 \%$ & $1.42[0.84,2.39]$ & & $t=$ \\
\hline Winner 2000 & 116 & 377 & 32 & 130 & $6.8 \%$ & $1.25[0.89,1.75]$ & & $=$ \\
\hline Winner 2002 & 48 & 149 & 40 & 142 & $6.4 \%$ & $1.14[0.81,1.62]$ & & 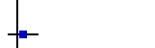 \\
\hline Winner 2006 & 191 & 483 & 68 & 242 & $9.9 \%$ & $1.41[1.12,1.77]$ & & $=$ \\
\hline Winner 2007 & 32 & 144 & 20 & 133 & $3.9 \%$ & $1.48[0.89,2.45]$ & & - \\
\hline Subtotal $(95 \% \mathrm{CI})$ & & 4216 & & 2474 & $98.8 \%$ & $1.31[1.18,1.46]$ & & 1 \\
\hline Total events: & 1290 & & 574 & & & & & \\
\hline \multicolumn{9}{|c|}{ Heterogeneity: $\mathrm{Tau}^{2}=0.01 ; \mathrm{Chi}^{2}=24.19, \mathrm{df}=18(\mathrm{P}=0.15) ; \mathrm{I}^{2}=26 \%$} \\
\hline \multicolumn{9}{|c|}{ Test for overall effect: $\mathrm{Z}=5.07(\mathrm{P}<0.00001)$} \\
\hline Total $(95 \%$ CI) & & 4268 & & 2526 & $100.0 \%$ & $1.33[1.19,1.49]$ & & 1 \\
\hline Total events: & 1308 & & 578 & & & & & \\
\hline \multicolumn{7}{|c|}{ Heterogeneity: $\mathrm{Tau}^{2}=0.02 ; \mathrm{Chi}^{2}=29.96, \mathrm{df}=20(\mathrm{P}=0.07) ; \mathrm{I}^{2}=33 \%$} & 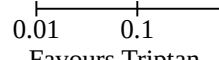 & 10 \\
\hline
\end{tabular}

ADDITIONAL TABLES

Table 1. Summary of characteristics of included studies

\begin{tabular}{llll}
\hline Study characteristics & Criteria & $\mathrm{N}=\mathbf{2 7} \boldsymbol{a}$ & \% \\
\hline Study design & Parallel & 16 & $59 \%$ \\
\cline { 2 - 4 } & Cross-over & 11 & $41 \%$ \\
\hline Sponsorship & Pharmaceutical & 19 & $70 \%$ \\
\cline { 2 - 4 } & Non-pharmaceutical & 5 & $19 \%$ \\
\cline { 2 - 4 } & & 5 & \multirow{2}{*}{5} \\
\hline
\end{tabular}


Table 1. Summary of characteristics of included studies (Continued)

\begin{tabular}{|c|c|c|c|}
\hline & Unclear & 3 & $11 \%$ \\
\hline \multirow[t]{3}{*}{ Age inclusion criteria } & Adolescents (12-17 years) & 17 & $63 \%$ \\
\hline & Children and adolescents & 6 & $22 \%$ \\
\hline & Children ( $<12$ years) & 4 & $15 \%$ \\
\hline \multirow[t]{3}{*}{ Pain scale } & 4-point scale & 21 & $78 \%$ \\
\hline & 5-faces scale & 5 & $18 \%$ \\
\hline & VAS & 1 & $4 \%$ \\
\hline \multirow{3}{*}{$\begin{array}{l}\text { Preventive medication per- } \\
\text { mitted? }\end{array}$} & Yes & 9 & $33 \%$ \\
\hline & No & 13 & $48 \%$ \\
\hline & Unclear & 5 & $19 \%$ \\
\hline \multirow[t]{2}{*}{ Route of delivery } & Oral & 19 & $70 \%$ \\
\hline & Intranasal & 8 & $30 \%$ \\
\hline \multirow[t]{4}{*}{ Medications } & Paracetamol & 1 & $4 \%$ \\
\hline & Ibuprofen & 3 & $7 \%$ \\
\hline & Triptans & 24 & $85 \%$ \\
\hline & DHE & 1 & $4 \%$ \\
\hline \multirow[t]{7}{*}{ Triptan medications } & Almotriptan & 1 & $4 \%$ \\
\hline & Eletriptan & 1 & $4 \%$ \\
\hline & Naratriptan & 1 & $4 \%$ \\
\hline & Rizatriptan & 4 & $17 \%$ \\
\hline & Sumatriptan & 12 & $50 \%$ \\
\hline & Sumatriptan + naproxen sodium & 1 & $4 \%$ \\
\hline & Zolmitriptan & 4 & $17 \%$ \\
\hline
\end{tabular}

DHE: dihydroergotamine; VAS: visual analogue scale.

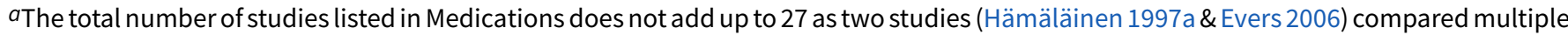
medications. 


\begin{tabular}{|c|c|c|c|c|c|c|c|c|}
\hline Review Manager ID & Study design & Agent & Route & $\begin{array}{l}\text { Child. } \\
\text { (<12 yrs) }\end{array}$ & $\begin{array}{l}\text { Adolesc. } \\
\text { (12-17 yrs) }\end{array}$ & Mean age & No & $\%$ Female \\
\hline \multicolumn{9}{|l|}{ Paracetamol } \\
\hline Hämäläinen 1997a & Cross-over & - & $\mathrm{PO}$ & Yes & Yes & 10.7 & 80 & $50 \%$ \\
\hline \multicolumn{9}{|l|}{ Ibuprofen } \\
\hline Hämäläinen 1997a & Cross-over & - & $\mathrm{PO}$ & Yes & Yes & 10.7 & 78 & $50 \%$ \\
\hline Lewis 2002 & Parallel & - & $\mathrm{PO}$ & Yes & No & 9.0 & 84 & ND \\
\hline Evers 2006 & Cross-over & - & $\mathrm{PO}$ & Yes & Yes & 13.9 & 29 & $56 \%$ \\
\hline \multicolumn{9}{|l|}{ Triptans (< 12 years) } \\
\hline Ho 2012 & Parallel & Rizatriptan & $\mathrm{PO}$ & Yes & NA & ND & 200 & $44 \%$ \\
\hline Ueberall 1999 & Cross-over & Sumatriptan & IN & Yes & No & 8.2 & 14 & $50 \%$ \\
\hline Hämäläinen 2002 & Cross-over & Sumatriptan & IN & Yes & No & 9.7 & 59 & $54 \%$ \\
\hline \multicolumn{9}{|l|}{ Triptans (12-17 years) } \\
\hline Linder 2008 & Parallel & Almotriptan & $\mathrm{PO}$ & No & Yes & 14.4 & 714 & $60 \%$ \\
\hline Winner 2007 & Parallel & Eletriptan & $\mathrm{PO}$ & No & Yes & 14.0 & 274 & $57 \%$ \\
\hline Rothner 1997 & Parallel & Naratriptan & $\mathrm{PO}$ & No & Yes & 14.3 & 300 & $54 \%$ \\
\hline Ho 2012 & Parallel & Rizatriptan & $\mathrm{PO}$ & NA & Yes & ND & 570 & $61 \%$ \\
\hline Visser 2004a & Parallel & Rizatriptan & $\mathrm{PO}$ & No & Yes & 14.2 & 476 & $55 \%$ \\
\hline Winner 2002 & Parallel & Rizatriptan & $\mathrm{PO}$ & No & Yes & 14.0 & 296 & $54 \%$ \\
\hline Ahonen 2006 & Cross-over & Rizatriptan & $\mathrm{PO}$ & Yes & Yes & 12.0 & 116 & $54 \%$ \\
\hline Callenbach 2007 & Cross-over & Sumatriptan & IN & No & Yes & 13.6 & 46 & $78 \%$ \\
\hline
\end{tabular}




\begin{tabular}{|c|c|c|c|c|c|c|c|c|}
\hline Rothner 1999b & Parallel & Sumatriptan & $\mathrm{PO}$ & No & Yes & 13.6 & 92 & $52 \%$ \\
\hline Winner 2000 & Parallel & Sumatriptan & IN & No & Yes & 14.1 & 507 & $52 \%$ \\
\hline Hämäläinen 1997b & Cross-over & Sumatriptan & $\mathrm{PO}$ & Yes & Yes & 12.3 & 23 & $52 \%$ \\
\hline Rothner 1999c & Parallel & Sumatriptan & $\mathrm{PO}$ & No & Yes & 13.5 & 102 & $42 \%$ \\
\hline Fujita 2014 & Parallel & Sumatriptan & $\mathrm{PO}$ & Yes & Yes & 14.1 & 144 & $58 \%$ \\
\hline Winner 1997 & Cross-over & Sumatriptan & PO & No & Yes & 13.9 & 298 & $58 \%$ \\
\hline Winner 2006 & Parallel & Sumatriptan & IN & No & Yes & 14.3 & 731 & $55 \%$ \\
\hline Ahonen 2004 & Cross-over & Sumatriptan & IN & Yes & Yes & 12.4 & 94 & $46 \%$ \\
\hline Rothner 1999a & Parallel & Sumatriptan & PO & No & Yes & 14.1 & 273 & $57 \%$ \\
\hline Derosier 2012 & Parallel & $\begin{array}{l}\text { Sumatriptan and } \\
\text { Naproxen Sodium }\end{array}$ & PO & No & Yes & 14.7 & 490 & $59 \%$ \\
\hline Lewis 2007 & Cross-over & Zolmitriptan & IN & No & Yes & 14.2 & 171 & $57 \%$ \\
\hline Evers 2006 & Cross-over & Zolmitriptan & PO & Yes & Yes & 13.9 & 29 & $56 \%$ \\
\hline Rothner 2006 & Parallel & Zolmitriptan & $\mathrm{PO}$ & No & Yes & 14.2 & 696 & $59 \%$ \\
\hline NCT01211145 & Parallel & Zolmitriptan & IN & No & Yes & 14 & 584 & ND \\
\hline \multicolumn{9}{|l|}{ Dihydroergotamine } \\
\hline Hämäläinen 1997c & Cross-over & - & $\mathrm{PO}$ & Yes & Yes & 10.3 & 13 & $38 \%$ \\
\hline
\end{tabular}

IN: intranasal; NA: not applicable; ND: no data available; No: total number in efficacy analysis (intention-to-treat when available); PO: per os (by mouth). 


\section{AP P E N D I CES}

\section{Appendix 1. Complete Search Strategy}

LITERATURE SEARCH-Drugs for the acute treatment of migraine in children and adolescents 


\begin{tabular}{|c|c|c|c|c|c|c|c|c|c|c|c|c|}
\hline Database & 2008 & & 2012 & & 2013 & & 2014 & & 2016 & & Total & \\
\hline & $\begin{array}{l}\text { Num- } \\
\text { ber re- } \\
\text { trieved }\end{array}$ & $\begin{array}{l}\text { After du- } \\
\text { plicates } \\
\text { removed }\end{array}$ & $\begin{array}{l}\text { Num- } \\
\text { ber re- } \\
\text { trieved }\end{array}$ & $\begin{array}{l}\text { After } \\
\text { dupli- } \\
\text { cates re- } \\
\text { moved }\end{array}$ & $\begin{array}{l}\text { Num- } \\
\text { ber re- } \\
\text { trieved }\end{array}$ & $\begin{array}{l}\text { After } \\
\text { dupli- } \\
\text { cates re- } \\
\text { moved }\end{array}$ & $\begin{array}{l}\text { Num- } \\
\text { ber re- } \\
\text { trieved }\end{array}$ & $\begin{array}{l}\text { After } \\
\text { dupli- } \\
\text { cates re- } \\
\text { moved }\end{array}$ & $\begin{array}{l}\text { Num- } \\
\text { ber re- } \\
\text { trieved }\end{array}$ & $\begin{array}{l}\text { After } \\
\text { dupli- } \\
\text { cates re- } \\
\text { moved }\end{array}$ & $\begin{array}{l}\text { Number } \\
\text { retrieved }\end{array}$ & $\begin{array}{l}\text { After du- } \\
\text { plicates } \\
\text { removed }\end{array}$ \\
\hline MEDLINE & 2844 & 2742 & 639 & 616 & 90 & 75 & - & - & 326 & 231 & 3899 & 3664 \\
\hline $\begin{array}{l}\text { MEDLINE In- } \\
\text { Process }\end{array}$ & 29 & 29 & 29 & 29 & 16 & 14 & - & - & - & - & 74 & 72 \\
\hline CCRT & 153 & 126 & 153 & 126 & 10 & 2 & - & - & - & - & 316 & 254 \\
\hline CDSR DARE & 664 & 650 & 664 & 650 & 324 & 169 & - & - & - & - & 1652 & 1469 \\
\hline IPA & 109 & 27 & 40 & 10 & 7 & 4 & - & - & - & - & 156 & 41 \\
\hline PsycINFO & 255 & 147 & 147 & 85 & 5 & 3 & - & - & - & - & 407 & 235 \\
\hline EMBASE & 6357 & 5548 & 2884 & 2517 & 508 & 412 & 794 & 787 & 626 & 516 & 11,169 & 9780 \\
\hline CINAHL & 712 & 190 & 263 & 70 & 31 & 21 & - & - & - & - & 1006 & 281 \\
\hline Total & 11,123 & 9459 & 4819 & 4103 & 991 & 700 & 794 & 787 & 952 & 747 & 18,679 & 15,796 \\
\hline
\end{tabular}


Searcher: Robin Featherstone

Requestor: Lawrence Richer

Date Submitted: 3 February 2016

Last update: 19 December 2014

Files submitted:

1. Richer-AcuteMigraine-Update_Feb2016.enlx

2. Richer-AcuteMigraine-Update_Feb2016.xlsx

Search Summary:

\begin{tabular}{llll}
\hline Database & Date Searched & Number Retrieved & After Duplicate Removala \\
\hline EMBASE & 3 February 2016 & 626 & 516 \\
\hline MEDLINE & 3 February 2016 & 326 & 231 \\
\hline Total & & $\mathbf{9 5 2}$ & $\mathbf{7 4 7}$ \\
\hline
\end{tabular}

aNote: Removed any records retrieved by previous updates.

Database: EMBASE via Ovid 1996 to 2016 Week 05

Search Title: Richer_Acute_Migraine_2016Update

Strategy:

Migraine-related terms:

1. exp Headache Disorders/

2. vascular headache/

3. headache/

4. (migraine\$ or headache\$ or head-ache\$ or cephalgia or cephalalgia).ti,ab.

5. or/1-4 (180,453)

Pharmaceutical related terms:

6. exp Drug Therapy/

7. (drug adj3 (therap\$ or treatment?)).mp.

8. ((anti-migrain\$ or antimigrain\$) adj3 (therap\$ or treatment?)).mp.

9. (ad or ae or dt or to).fs.

10. exp Treatment Outcome/

11. exp Analgesics/ 
12. "nonsteroidal anti-inflammatory agent?".mp.

13. "non-steroidal anti-inflammatory agent?".mp.

14. NSAID?.mp.

15. ibuprofen.mp.

16. fenoprofen.mp.

17. flurbiprofen.mp.

18. ketoprofen.mp.

19. ketorolac.mp.

20. diclofenac.mp.

21. etodolac.mp.

22. sulindac.mp.

23. diflunisal.mp.

24. naproxen.mp.

25. oxaprozin.mp.

26. tiaprofenic acid.mp.

27. mefenamic acid.mp.

28. indomethacin.mp.

29. tolmetin.mp.

30. celecoxib.mp.

31. meloxicam.mp.

32. piroxicam.mp.

33. tenoxicam.mp.

34. floctafenin\$.mp.

35. nabumeton\$.mp.

36. acetaminophen.mp.

37. paracetamol.mp.

38. ergot\$ alkaloid?.mp.

39. ergotamin\$.mp.

40. dihydroergotoxin $\$ . m p$.

41. dihydroergotamin\$.mp.

42. DHE.mp.

43. ergoloid mesylates.mp.

44. methysergide.mp.

45. ziconotide.mp. 
46. opioid\$.mp.

47. opiate\$.mp.

48. opium.mp.

49. meperidine.mp.

50. alfentan\#l.mp.

51. fentan\#l.mp.

52. rem\#fentan\#l.mp.

53. sufentan\#l.mp.

54. levomethadyl.mp.

55. butorphanol.mp.

56. codein?.mp.

57. morphine.mp.

58. pentazocin\$.mp.

59. (propoxyphen\$ or dextro?propoxyphen\$).mp.

60. nalbuphin\$.mp.

61. hydromorphon\$.mp.

62. oxycodon\$.mp.

63. oxymorphon\$.mp.

64. methadon\$.mp.

65. butalbital.mp.

66. aspirin.mp.

67. acetylsalicylic acid.mp.

68. caffeine.mp.

69. "combination analgesic?".tw.

70. APAP.tw.

71. dichloralphenazone.mp.

72. isomethepten $\$ . m p$.

73. corticosteroid\$.mp.

74. hydrocortisone.mp.

75. prednisolone.mp.

76. methylprednisolone.mp.

77. dexamethasone.mp.

78. tryptamin\$.mp.

79. triptan?.mp. 
80. sumatriptan.mp.

81. naratriptan.mp.

82. rizatriptan. $\mathrm{mp}$.

83. zolmitriptan.mp.

84. almotriptan.mp.

85. eletriptan.mp.

86. frovatriptan.mp.

87. serotonin agonist?.mp.

88. ((5-hydroxytryptamine or 5-HT) adj2 agonist?).mp.

89. (antiemetic? or anti-emetic?).mp.

90. (antinauseant? or anti-nauseant?).mp.

91. chlorpromazine.mp.

92. prochlorperazine.mp.

93. perphenazine.mp.

94. trifluoperazine.mp.

95. (met\#clopr\#mide or metochlopramide).mp.

96. scopolamin\$.mp.

97. dimenhydrinate.mp.

98. dronabinol.mp.

99. nabilon\$.mp.

100. thiethylperazine.mp.

101. trimethobenzamide.mp.

102. ondansetron.mp.

103. granisetron.mp.

104. dolasetron.mp.

105. diphenhydramine.mp.

106. hydroxyzine.mp.

107. promethazine.mp.

108. Valproic Acid.mp.

109. valproate.mp.

110. divalproex sodium.mp.

111. Clonidine.mp.

112. fluid bolus.mp.

113. normal saline.mp. 
114. magnesium.mp.

115. lidocaine.mp.

116. Botulinum Toxin Type A/

117. botulinium toxin.mp.

118. botox.mp.

119. oxygen.mp.

120. placebo\$.mp.

121. or/6-120 [combination of all pharmaceutical treatments for migraine]

RCT filter:

122. random ${ }^{\star}$.tw.

123. placebo*.mp.

124. double-blind ${ }^{*}$.tw.

125. or/122-124 [RCT filter from J Med Libr Assoc 2006]

Child related terms:

126. adolescent/

127. child/

128. newborn/

129. exp Pediatrics/

130. infant\$.mp.

131. infancy.mp.

132. newborn\$.mp.

133. baby.mp.

134. babies.mp.

135. neonat\$.mp.

136. preterm\$.mp.

137. prematur\$.mp.

138. postmatur\$.mp.

139. child\$.mp.

140. kid.mp.

141. kids.mp.

142. toddler\$.mp.

143. adolescen\$.mp.

144. teen\$.mp.

145. juvenile\$.mp. 
146. boy\$.mp.

147. girl.mp.

148. girls.mp.

149. minor\$.mp.

150. pubert\$.mp.

151. pubescen\$.mp.

152. pediatric\$.mp.

153. paediatric\$.mp.

154. peadiatric\$.mp.

155. or/126-154 [child filter as per original search]

156. and $/ 5,121,125,155$ [combination of migraine + drugs + RCT + child]

157. limit 156 to em $=201450-201605$ (639)

158. remove duplicates from 157 (626)

Database: Ovid MEDLINE(R) In-Process \& Other Non-Indexed Citations and Ovid MEDLINE(R) 1946 to Present

Search Title: Richer_Acute_Migraine_2016Update_1

Strategy:

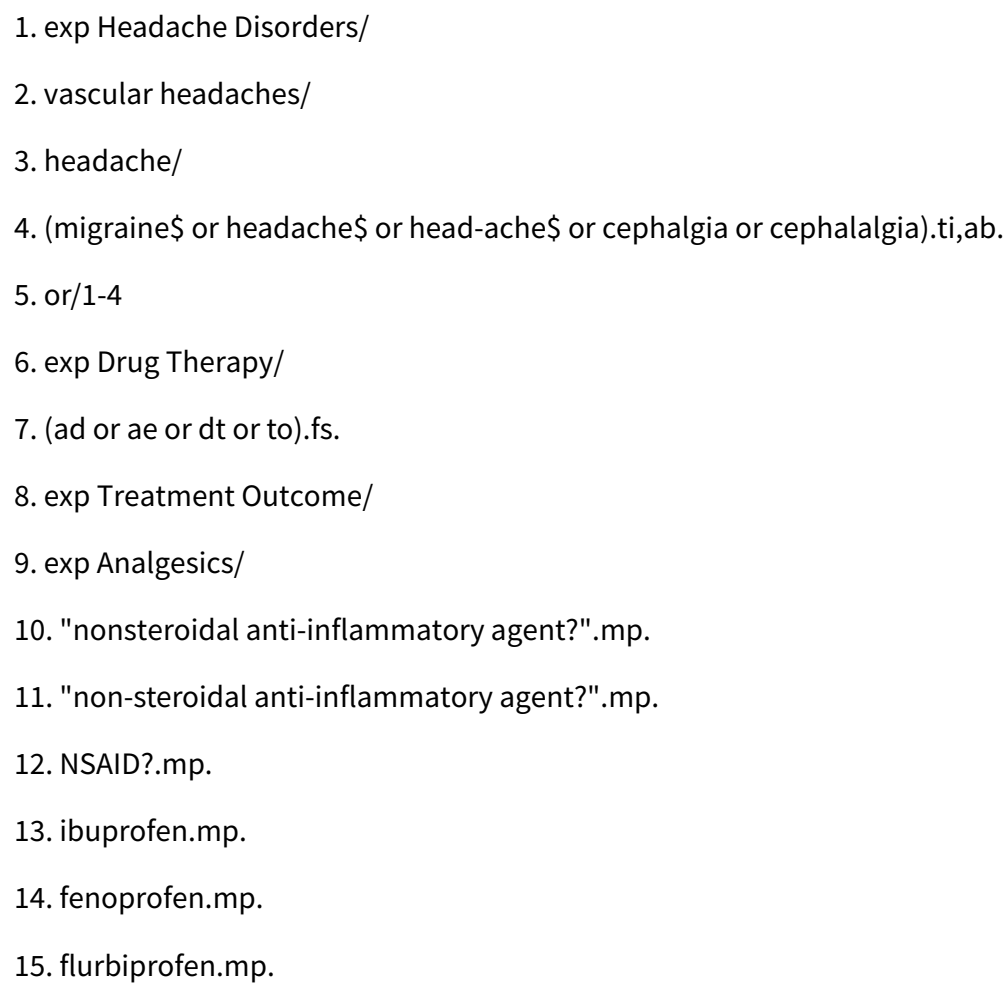

16. ketoprofen.mp.

Drugs for the acute treatment of migraine in children and adolescents (Review) 
17. ketorolac.mp.

18. diclofenac.mp.

19. etodolac.mp.

20. sulindac.mp.

21. naproxen.mp.

22. tolmetin.mp.

23. oxaprozin.mp.

24. tenoxicam.mp.

25. tiaprofenic acid.mp.

26. mefenamic acid.mp.

27. ((acetylsalicylic adj1 acid) or aspirin).mp.

28. piroxicam.mp.

29. celecoxib.mp.

30. meloxicam.mp.

31. indomethacin.mp.

32. floctafenin\$.mp.

33. nabumeton\$.mp.

34. acetaminophen.mp.

35. paracetamol.mp.

36. ergotamin\$.mp.

37. dihydroergotamin\$.mp.

38. DHE.mp.

39. opioid\$.mp.

40. opium.mp.

41. methadon\$.mp.

42. meperidine.mp.

43. butorphanol.mp.

44. hydromorphon\$.mp.

45. morphin\$.mp.

46. codein?.mp

47. butalbital.mp.

48. pentazocine.mp.

49. propoxyphene.mp.

50. nalbuphine.mp. 
51. oxycodon\$.mp.

52. ocymorphon\$.mp.

53. alfentanil.mp.

54. fentanyl.mp.

55. sufentanil.mp.

56. caffeine.mp.

57. "combination analgesic?".tw.

58. tryptamines.mp.

59. triptan?.mp

60. sumatriptan.mp.

61. naratriptan.mp.

62. rizatriptan.mp.

63. zolmitriptan.mp.

64. almotriptan.mp.

65. eletriptan.mp.

66. frovatriptan.mp.

67. serotonin agonist?.mp.

68. ((5-hydroxytriptamine or 5-HT) adj2 agonist?).mp.

69. (antiemetic? or anti-emetic?).mp. [mp=title, abstract, original title, name of substance word, subject heading word, keyword heading word, protocol supplementary concept word, rare disease supplementary concept word, unique identifier]

70. (antinauseant? or anti-nauseant?).mp.

71. thiethylperazin\$.mp.

72. trimethobenzamid\$.mp.

73. scopolamin\$.mp.

74. chlorpromazine.mp.

75. prochlorperazine.mp.

76. promethazin\$.mp.

77. perphenazin\$.mp.

78. trifluoperazin\$.mp.

79. met\#clopr\#mide.mp.

80. ondansetron.mp.

81. granisetron.mp.

82. dolasetron.mp.

83. diphenhydramine.mp.

84. hydroxyzine.mp. 
85. dimenhydrinate.mp.

86. dronabinol.mp.

87. nabilone.mp.

88. fluid bolus.mp.

89. normal saline.mp.

90. magnesium.mp.

91. lidocaine.mp.

92. corticosteroid\$.mp.

93. prednisolone.mp.

94. solumedrol.mp.

95. dexamethason\$.mp.

96. hydrocortisol.mp.

97. exp methylprednisolone/

98. Botulinum Toxin Type A/

99. botulinium toxin.mp.

100. botox.mp.

101. oxygen.mp.

102. clonidine.mp.

103. diflunisal.mp.

104. (levomethadyl or levo-methadyl).mp.

105. remifentanil.mp.

106. ziconotid\$.mp.

107. placebo\$.mp.

108. (antimigrain\$ or anti-migrain\$).mp.

109. divalproex.mp.

110. methysergid\$.mp.

111. (ergoloid adj1 mesylate\$).mp.

112. (abortive adj3 (therap\$ or treatment\$)).mp.

113. or/6-112

114. and $/ 5,113$

115. clinical trial.pt.

116. randomized controlled trial.pt.

117. randomi?ed.ti,ab.

118. placebo.ti,ab. 
119. dt.fs.

120. randomly.ti,ab.

121. trial.ti,ab.

122. groups.ti,ab.

123. or/115-122

124. animals/

125. humans/

126. 124 not (124 and 125)

127. 123 not 126

128. exp Infant/

129. exp Child/

130. Adolescent/

131. Minors/

132. exp Puberty/

133. exp Pediatrics/

134. infant\$.mp.

135. infancy.mp.

136. newborn\$.mp.

137. baby.mp.

138. babies.mp.

139. neonat\$.mp.

140. preterm\$.mp.

141. prematur\$.mp.

142. postmatur\$.mp.

143. child\$.mp.

144. kid.mp.

145. kids.mp.

146. toddler\$.mp.

147. adolescen\$.mp.

148. teen\$.mp.

149. boy\$.mp.

150. girl.mp.

151. minor\$.mp.

152. pubert\$়.mp. 
153. pubescen\$.mp.

154. prepubescen\$.mp.

155. pediatric\$.mp.

156. paediatric\$.mp.

157. peadiatric\$.mp.

158. or/128-156

159. and $/ 114,127,158$

160. limit 159 to ed=20141219-20161231

161. remove duplicates from 160

Searcher: Robin Featherstone (original strategy Andrea Milne)

Requestor: Lawrence Richer

Date Requested: 3 December 2014

Date Submitted: 19 December 2014

NOTE: Last update: April 2013

Search Summary:

\begin{tabular}{llll}
\hline Database & Date Searched & Number Retrieved & After Duplicates Removed \\
\hline EMBASE & 19 December 2014 & 794 & 787 \\
\hline
\end{tabular}

Database: EMBASE via Ovid 1996 to 2014 Week 50

Search Title: Migraine Acute - L Richer - Update 2.0 | EMBASE - 19 Dec 2014 - RF

Date Searched: 19 December 2014

Results:

\footnotetext{
Migraine related terms:

1. exp Headache Disorders/

2. vascular headache/

3. headache/

4. (migraine\$ or headache\$ or head-ache\$ or cephalgia or cephalalgia).ti,ab.

5. or/1-4 (180,453)

Pharmaceutical related terms:
} 


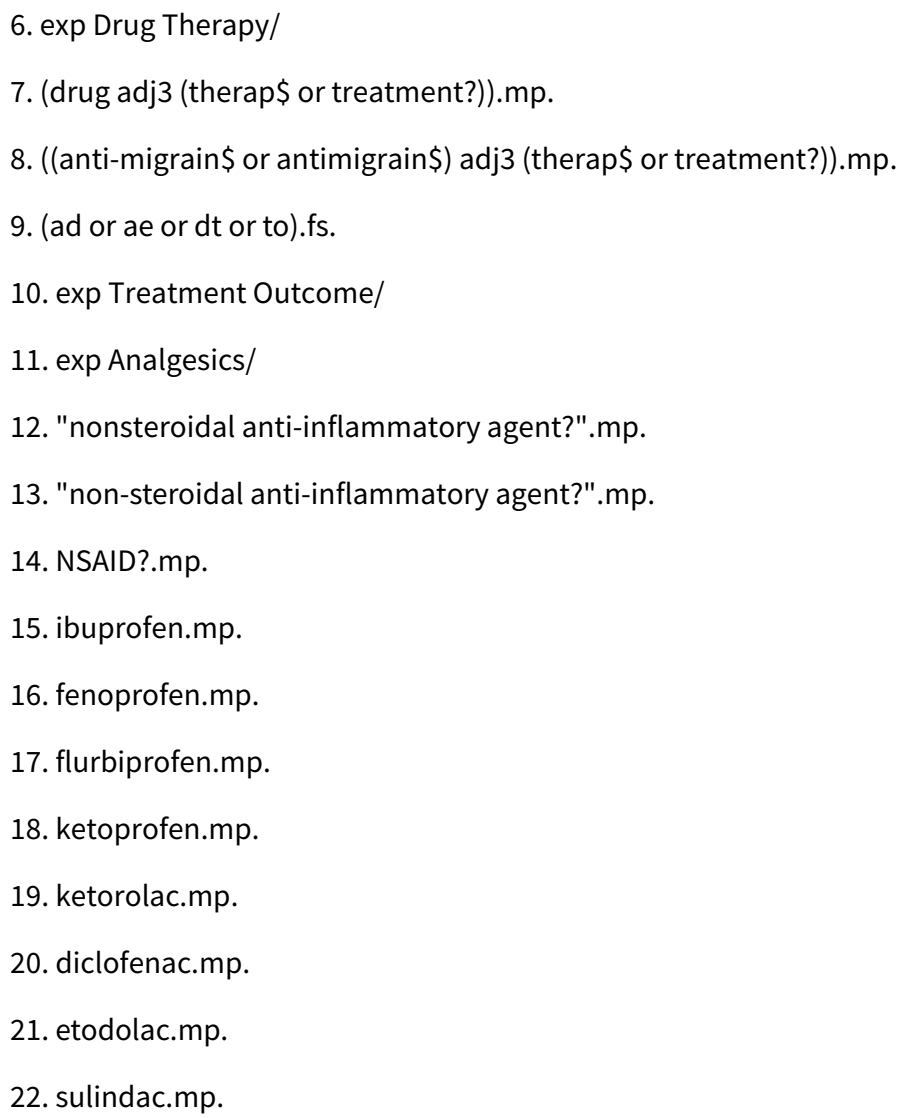

20. diclofenac.mp.

21. etodolac.mp.

22. sulindac.mp.

23. diflunisal.mp.

24. naproxen.mp.

25. oxaprozin.mp.

26. tiaprofenic acid.mp.

27. mefenamic acid.mp.

28. indomethacin.mp.

29. tolmetin.mp.

30. celecoxib.mp.

31. meloxicam.mp.

32. piroxicam.mp.

33. tenoxicam.mp.

34. floctafenin\$.mp.

35. nabumeton\$.mp.

36. acetaminophen.mp.

37. paracetamol.mp.

38. ergot\$ alkaloid?.mp.

39. ergotamin\$.mp. 
40. dihydroergotoxin\$.mp.

41. dihydroergotamin\$.mp.

42. DHE.mp.

43. ergoloid mesylates.mp.

44. methysergide.mp.

45. ziconotide.mp.

46. opioid\$.mp.

47. opiate\$.mp.

48. opium.mp.

49. meperidine.mp.

50. alfentan\#l.mp.

51. fentan\#l.mp.

52. rem\#fentan\#l.mp.

53. sufentan\#l.mp.

54. levomethadyl.mp.

55. butorphanol.mp.

56. codein?.mp.

57. morphine.mp.

58. pentazocin\$.mp.

59. (propoxyphen\$ or dextro?propoxyphen\$).mp.

60. nalbuphin\$.mp.

61. hydromorphon\$.mp.

62. oxycodon\$.mp.

63. oxymorphon\$.mp.

64. methadon\$.mp.

65. butalbital.mp.

66. aspirin.mp.

67. acetylsalicylic acid.mp.

68. caffeine.mp.

69. "combination analgesic?".tw.

70. APAP.tw.

71. dichloralphenazone.mp.

72. isomethepten\$.mp.

73. corticosteroid\$.mp. 


\section{4. hydrocortisone.mp. \\ 75. prednisolone.mp.}

76. methylprednisolone.mp.

77. dexamethasone.mp.

78. tryptamin\$.mp.

79. triptan?.mp.

80. sumatriptan.mp.

81. naratriptan.mp.

82. rizatriptan.mp.

83. zolmitriptan.mp.

84. almotriptan.mp.

85. eletriptan.mp.

86. frovatriptan.mp.

87. serotonin agonist?.mp.

88. ((5-hydroxytryptamine or 5-HT) adj2 agonist?).mp.

89. (antiemetic? or anti-emetic?).mp.

90. (antinauseant? or anti-nauseant?).mp.

91. chlorpromazine.mp.

92. prochlorperazine.mp.

93. perphenazine.mp.

94. trifluoperazine.mp.

95. (met\#clopr\#mide or metochlopramide).mp.

96. scopolamin\$.mp.

97. dimenhydrinate.mp.

98. dronabinol.mp.

99. nabilon\$.mp.

100. thiethylperazine.mp.

101. trimethobenzamide.mp.

102. ondansetron.mp.

103. granisetron.mp.

104. dolasetron.mp.

105. diphenhydramine.mp.

106. hydroxyzine.mp.

107. promethazine.mp. 
108. Valproic Acid.mp.

109. valproate.mp.

110. divalproex sodium.mp.

111. Clonidine.mp.

112. fluid bolus.mp.

113. normal saline.mp.

114. magnesium.mp.

115. lidocaine.mp.

116. Botulinum Toxin Type A/

117. botulinium toxin.mp.

118. botox.mp.

119. oxygen.mp.

120. placebo\$.mp.

121. or/6-120 [combination of all pharmaceutical treatments for migraine] $(4,461,554)$

RCT filter:

122. random*.tw.

123. placebo*.mp.

124. double-blind*.tw.

125. or/122-124 [RCT filter from J Med Libr Assoc 2006] $(938,236)$

Child related terms:

126. adolescent/

127. child/

128. newborn/

129. exp Pediatrics/

130. infant\$.mp.

131. infancy.mp.

132. newborn\$.mp.

133. baby.mp.

134. babies.mp.

135. neonat\$.mp.

136. preterm\$.mp.

137. prematur\$.mp.

138. postmatur\$.mp.

139. child\$.mp. 
140. kid.mp.

141. kids.mp.

142. toddler\$.mp.

143. adolescen\$.mp.

144. teen\$.mp.

145. juvenile\$.mp.

146. boy\$.mp.

147. girl.mp.

148. girls.mp.

149. minor\$.mp.

150. pubert\$.mp.

151. pubescen\$.mp.

152. pediatric $\$ . m p$.

153. paediatric\$.mp.

154. peadiatric\$.mp.

155. or/126-154 [child filter as per original search]

156. and/5,121,125,155 [combination of migrain + drugs + RCT + child] $(6,679)$

157. $2014^{\star}$.dp,em,yr. [date of publication, entry date, year of publication limits] $(1,525,211)$

158. ("201318" or "201319" or 20132* or $20133^{\star}$ or $20134^{\star}$ or $\left.20135^{\star}\right)$.em. [entry date limit] $(1,086,901)$

159. (or/157,158) and 156 [application of date limits] (931)

$160 .\left(1996^{\star}\right.$ or $1997^{\star}$ or $1998^{\star}$ or $1999^{\star}$ or $2000^{\star}$ or $2001^{\star}$ or $2002^{\star}$ or $2003^{\star}$ or $2004^{\star}$ or $2005^{\star}$ or $2006^{\star}$ or $2007^{\star}$ or $2008^{\star}$ or $2009^{\star}$ or $2010^{\star}$ or $2011^{\star}$ or $2012^{\star}$ or $2013^{\star}$ or $\left.2014^{\star}\right)$.dp,em,yr

161. 159 not $160(794)$

162. remove duplicates from 161 (787)

Search Summary (update after June 2008):

\begin{tabular}{lllllc}
\hline Review & $\begin{array}{l}\text { Number Re- } \\
\text { trieved }\end{array}$ & $\begin{array}{l}\text { After Dupli- } \\
\text { cate Removal }\end{array}$ & Update Search Date & $\begin{array}{l}\text { Number Re- } \\
\text { trieved }\end{array}$ & $\begin{array}{l}\text { After Dupli- } \\
\text { cate Removal }\end{array}$ \\
\hline MEDLINE & 639 & 616 & 29 April 2013 & 90 & 75 \\
\hline MEDLINE In-Process & 29 & 29 & 29 April 2013 & 16 & 14 \\
\hline CCRT & 153 & 127 & 29 April 2013 & 324 & 2 \\
\hline CDSR DARE & 664 & 650 & 29 April 2013 & 169 \\
\hline
\end{tabular}


(Continued)

\begin{tabular}{lllll} 
IPA & 40 & 10 & 29 April 2013 & 4 \\
\hline PsycINFO & 147 & 85 & 29 April 2013 & 3 \\
\hline EMBASE & 2,884 & 2,511 & 30 April 2013 & 508 \\
\hline CINAHL & 213 & 70 & 30 April 2013 & 31 \\
\hline Total & $\mathbf{4 7 6 9}$ & $\mathbf{4 0 9 8}$ & $\mathbf{6 9 9}$ \\
\hline
\end{tabular}

Database: MEDLINE via Ovid <1946 to Present>

Search Title: Migraine Acute - L Richer - Update 1.0 | MEDLINE - 7 June 2012 - AM

\section{Migraine related terms:}

1. exp Headache Disorders/

2. vascular headaches/

3. headache/

4. (migraine\$ or headache\$ or head-ache\$ or cephalgia or cephalalgia).ti,ab.

5. or/1-4 (70,483)

\section{Pharmaceutical related terms:}
6. exp Drug Therapy/
7. (ad or ae or dt or to).fs.
8. exp Treatment Outcome/
9. exp Analgesics/
10. "nonsteroidal anti-inflammatory agent?".mp.
11. "non-steroidal anti-inflammatory agent?".mp.
12. NSAID?.mp.
13. ibuprofen.mp.
14. fenoprofen.mp.
15. flurbiprofen.mp.
16. ketoprofen.mp.
17. ketorolac.mp.
18. diclofenac.mp.
19. etodolac.mp.
20. sulindac.mp.
21. naproxen.mp. 
(Continued)

22. tolmetin.mp.

23. oxaprozin.mp.

24. tenoxicam.mp.

25. tiaprofenic acid.mp.

26. mefenamic acid.mp.

27. ((acetylsalicylic adj1.acid) or aspirin).mp.

28. piroxicam.mp.

29. celecoxib.mp.

30. meloxicam.mp

31. indomethacin.mp.

32. floctafenin\$.mp.

33. nabumeton\$.mp.

34. acetaminophen.mp.

35. paracetamol.mp.

36. ergotamin\$.mp.

37. dihydroergotamin\$.mp.

38. DHE.mp

39. opioid\$.mp.

40. opium.mp.

41. methadon\$.mp.

42. meperidine.mp.

43. butorphanol.mp

44. hydromorphon\$.mp

45. morphin\$.mp.

46. codein?.mp.

47. butalbital.mp.

48. pentazocine.mp

49. propoxyphene.mp.

50. nalbuphine.mp.

51. oxycodon\$.mp.

52. ocymorphon\$.mp.

53. alfentanil.mp.

54. fentanyl.mp.

55. sufentanil.mp. 
(Continued)

56. caffeine.mp

57. "combination analgesic?".tw.

58. tryptamines.mp.

59. triptan?.mp.

60. sumatriptan.mp.

61. naratriptan.mp.

62. rizatriptan.mp.

63. zolmitriptan.mp.

64. almotriptan.mp.

65. eletriptan.mp.

66. frovatriptan.mp.

67. serotonin agonist?.mp.

68. ((5-hydroxytriptamine or 5-HT) adj2 agonist?).mp.

69. (antiemetic? or anti-emetic?).mp.

70. (antinauseant? or anti-nauseant?).mp.

71. thiethylperazin $\$ . m p$.

72. trimethobenzamid\$.mp.

73. scopolamin\$.mp.

74. chlorpromazine.mp.

75. prochlorperazine.mp.

76. promethazin\$.mp.

77. perphenazin\$.mp.

78. trifluoperazin\$.mp.

79. met\#clopr\#mide.mp

80. ondansetron.mp

81. granisetron.mp.

82. dolasetron.mp

83. diphenhydramine.mp.

84. hydroxyzine.mp.

85. dimenhydrinate.mp.

86. dronabinol.mp.

87. nabilone.mp.

88. fluid bolus.mp.

89. normal saline.mp. 
(Continued)

90. magnesium.mp.

91. lidocaine.mp.

92. corticosteroid\$.mp.

93. prednisolone.mp.

94. solumedrol.mp.

95. dexamethason\$.mp.

96. hydrocortisol.mp.

97. exp methylprednisolone/

98. Botulinum Toxin Type A/

99. botulinium toxin.mp.

100. botox.mp.

101. oxygen.mp.

102. clonidine.mp.

103. diflunisal.mp.

104. (levomethadyl or levo-methadyl).mp.

105. remifentanil.mp.

106. ziconotid\$.mp.

107. placebo\$.mp.

108. (antimigrain\$ or anti-migrain\$).mp.

109. divalproex.mp.

110. methysergid\$.mp.

111. (ergoloid adj1 mesylate\$).mp.

112. (abortive adj3 (therap\$ or treatment\$)).mp.

113. or/6-112 $(4,457,175)$

RCT filter:

114. and/5,113 $(33,933)$

115. randomized controlled trial.pt.

116. controlled clinical trial.pt.

117. randomized.ab.

118. placebo.ab.

119. clinical trials as topic.sh.

120. randomly.ab.

121. trial.ti.

122. or/115-121 $(762,426)$

Drugs for the acute treatment of migraine in children and adolescents (Review) 
(Continued)

123. exp animals/ not humans.sh. $(3,730,608)$

124. 122 not 123 [Updated Cochrane RCT filter max specificity and precision] $(702,878)$

Child related terms:

125. exp Infant/

126. exp Child/

127. Adolescent/

128. Minors/

129. exp Puberty/

130. exp Pediatrics/

131. infant\$.mp.

132. infancy.mp.

133. newborn\$.mp.

134. baby.mp.

135. babies.mp.

136. neonat\$.mp.

137. preterm\$.mp.

138. prematur\$.mp.

139. postmatur\$.mp.

140. child\$.mp.

141. kid.mp.

142. kids.mp.

143. toddler\$.mp.

144. adolescen\$.mp.

145. teen\$.mp.

146. boy\$.mp.

147. girl.mp.

148. minor\$.mp.

149. pubert\$.mp.

150. pubescen\$.mp.

151. prepubescen\$.mp.

152. pediatric\$.mp.

153. paediatric\$.mp.

154. peadiatric\$.mp. 
(Continued)

155. or/125-154 (3,241,093)

156. and/114,124,155 [combination of migraine + drug terms + RCT filter + child filter] $(2,844)$

Date limits for update:

157. limit 156 to ed="20080101-20120630" (639)

158. $\left(2008^{\star}\right.$ or $2009^{\star}$ or $\left.201^{\star}\right)$.dp,ep,yr. [date of publication (.dp), electronic date of entry (.ep) and year (.yr) search fields for update] $(3,078,760)$

159. and/156,158 [application of date restrictions to search results] (599)

160. or/157,159 [combination of entry date and other date restrictions] (639)

Date limits for update 2013:

161. limit 156 to ed="20120630-20130430" (90)

162. (2012 jun* or $\left.2013^{\star}\right)$.dp,ep. [date of publication (.dp), electronic date of entry (.ep)] $(95,823)$

163. and/156,162 [application of date restrictions to search results] (12)

164. or/161,163 [combination of date restrictions] (90)

Database: MEDLINE In-Process via Ovid < June 12, 2012>

Search Title: Migraine Acute - L Richer - Update 3.0 | Keyword Search - 8 June 2012 - AM

\section{Migraine related terms:}

1. (migraine\$ or headache\$ or head-ache\$ or cephalgia or cephalalgia).mp. $(3,432)$

\section{Pharmaceutical related terms:}

2. (drug adj3 (therap\$ or treatment?)).mp.

3. ((anti-migrain\$ or antimigrain\$) adj3 (therap\$ or treatment?)).mp.

4. (treatment adj5.outcome).mp.

5. analgesi\$.mp.

6. "nonsteroidal anti-inflammatory agent?".mp.

7. "non-steroidal anti-inflammatory agent?".mp.

8. NSAID?.mp.

9. ibuprofen.mp.

10. fenoprofen.mp.

11. flurbiprofen.mp.

12. ketoprofen.mp.

13. ketorolac.mp. 
(Continued)

14. diclofenac.mp.

15. etodolac.mp.

16. sulindac.mp.

17. diflunisal.mp.

18. naproxen.mp.

19. oxaprozin.mp.

20. tiaprofenic acid.mp.

21. mefenamic acid.mp.

22. indomethacin.mp.

23. tolmetin.mp.

24. celecoxib.mp

25. meloxicam.mp.

26. piroxicam.mp.

27. tenoxicam.mp.

28. floctafenin\$.mp.

29. nabumeton\$.mp.

30. acetaminophen.mp.

31. paracetamol.mp.

32. ergot\$ alkaloid?.mp.

33. ergotamin\$.mp.

34. dihydroergotoxin\$.mp.

35. dihydroergotamin\$.mp.

36. DHE.mp.

37. ergoloid mesylates.mp.

38. methysergide.mp.

39. ziconotide.mp.

40. opioid\$.mp.

41. opiate\$.mp

42. opium.mp.

43. meperidine.mp.

44. alfentan\#l.mp.

45. fentan\#l.mp.

46. rem\#fentan\#I.mp.

47. sufentan\#l.mp. 
(Continued)

48. levomethadyl.mp.

49. butorphanol.mp.

50. codein?.mp.

51. morphine.mp.

52. pentazocin\$.mp.

53. (propoxyphen\$ or dextro?propoxyphen\$).mp.

54. nalbuphin\$.mp.

55. hydromorphon\$.mp.

56. oxycodon\$.mp

57. oxymorphon\$.mp.

58. methadon\$.mp.

59. butalbital.mp.

60. aspirin.mp.

61. acetylsalicylic acid.mp.

62. caffeine.mp.

63. "combination analgesic?".tw.

64. APAP.tw.

65. dichloralphenazone.mp.

66. isomethepten\$.mp.

67. corticosteroid\$.mp.

68. hydrocortisone.mp.

69. prednisolone.mp.

70. methylprednisolone.mp.

71. dexamethasone.mp.

72. tryptamin $\$ . m p$.

73. triptan?.mp.

74. sumatriptan.mp.

75. naratriptan.mp

76. rizatriptan.mp.

77. zolmitriptan.mp.

78. almotriptan.mp.

79. eletriptan.mp.

80. frovatriptan.mp.

81. serotonin agonist?.mp. 
(Continued)

82. ((5-hydroxytryptamine or 5-HT) adj2 agonist?).mp.

83. (antiemetic? or anti-emetic?).mp.

84. (antinauseant? or anti-nauseant?).mp.

85. chlorpromazine.mp.

86. prochlorperazine.mp.

87. perphenazine.mp.

88. trifluoperazine.mp.

89. (met\#clopr\#mide or metochlopramide).mp.

90. scopolamin\$.mp.

91. dimenhydrinate.mp.

92. dronabinol.mp.

93. nabilon\$.mp.

94. thiethylperazine.mp.

95. trimethobenzamide.mp.

96. ondansetron.mp.

97. granisetron.mp.

98. dolasetron.mp.

99. diphenhydramine.mp.

100. hydroxyzine.mp.

101. promethazine.mp.

102. Valproic Acid.mp.

103. valproate.mp.

104. divalproex sodium.mp.

105. Clonidine.mp.

106. fluid bolus.mp.

107. normal saline.mp.

108. magnesium.mp.

109. lidocaine.mp.

110. botulinium toxin.mp.

111. botox.mp.

112. oxygen.mp.

113. placebo\$.mp.

114. or/2-113 [migraine drugs] $(50,953)$

RCT filter: 
(Continued)

115. randomized controlled trial.pt.

116. controlled clinical trial.pt.

117. randomized.ab.

118. placebo.ab.

119. randomly.ab.

120. trial.ti.

121. or/115-120 (27,679)

122. exp animals/ not humans.sh. (1)

123. 121.not 122 [Cochrane RCT filter, slightly modified for database] $(27,679)$

124. and/1,114,123 [combination of migraine + drugs + RCT terms] (233)

Child related terms:

125. infant\$.mp.

126. infancy.mp.

127. newborn\$.mp.

128. baby.mp.

129. babies.mp.

130. neonat\$়.mp.

131. preterm\$.mp.

132. prematur\$.mp.

133. postmatur\$.mp.

134. child\$.mp.

135. kid.mp.

136. kids.mp

137. toddler\$.mp.

138. adolescen\$.mp.

139. teen\$.mp.

140. boy\$.mp.

141. girl.mp.

142. girls.mp.

143. minor\$.mp.

144. pubert\$.mp.

145. pubescen\$.mp.

146. pediatric\$.mp.

147. paediatric\$.mp. 
(Continued)

148. peadiatric\$.mp.

149. or/125-148 [child filter] $(66,612)$

150. and/124,149 [migraine + drug + RCT + child] (29)

Date limits for update:

151. $\left(2008^{\star}\right.$ or $2009^{\star}$ or $\left.201^{\star}\right)$.ed,ep,up,yr. [entry date, e-pub date, update code, year of pub] $(1,343,461)$

152. 150 and 151 (29)

Date limits for update 2013:

153. ("2012" or "2013").ed,ep,up,yr. [entry date, e-pub date, update code, year of pub] $(471,980)$

154. and/150,153 (16)

Database Searched: Evidence Based Medicine Reviews via Ovid: Cochrane Central Register of Controlled Trials $<$ May $2012>$

Search Title: Migraine Acute - L Richer - Update 1.1 | Cochrane - no SD filters - 11 June 2012 - AM

\section{Migraine related terms:}

1. exp Headache Disorders/

2. vascular headaches/

3. headache/

4. (migraine\$ or headache\$ or head-ache\$ or cephalgia or cephalalgia).ti,ab.

\section{5. or/1-4 $(8,180)$}

Pharmaceutical related terms:
6. exp Drug Therapy/
7. (ad or ae or dt or to).fs.
8. exp Treatment Outcome/
9. $\exp$ Analgesics/
10. "nonsteroidal anti-inflammatory agent?".mp.
11. "non-steroidal anti-inflammatory agent?".mp.
12. NSAID?.mp.
13. ibuprofen.mp.
14. fenoprofen.mp.
15. flurbiprofen.mp.
16. ketoprofen.mp. 
(Continued)

17. ketorolac.mp.

18. diclofenac.mp.

19. etodolac.mp.

20. sulindac.mp.

21. naproxen.mp.

22. tolmetin.mp.

23. oxaprozin.mp

24. tenoxicam.mp.

25. tiaprofenic acid.mp.

26. mefenamic acid.mp.

27. ((acetylsalicylic adj1 acid) or aspirin).mp.

28. piroxicam.mp.

29. celecoxib.mp.

30. meloxicam.mp.

31. indomethacin.mp.

32. floctafenin\$.mp.

33. nabumeton\$.mp.

34. acetaminophen.mp.

35. paracetamol.mp.

36. ergotamin\$.mp.

37. dihydroergotamin\$.mp.

38. DHE.mp.

39. opioid\$.mp

40. opium.mp.

41. methadon\$.mp.

42. meperidine.mp.

43. butorphanol.mp.

44. hydromorphon\$.mp

45. morphin\$.mp.

46. codein?.mp.

47. butalbital.mp.

48. pentazocine.mp.

49. propoxyphene.mp.

50. nalbuphine.mp. 
(Continued)

51. oxycodon\$.mp.

52. ocymorphon\$.mp.

53. alfentanil.mp.

54. fentanyl.mp.

55. sufentanil.mp.

56. caffeine.mp.

57. "combination analgesic?".tw.

58. tryptamines.mp.

59. triptan?.mp.

60. sumatriptan.mp.

61. naratriptan.mp.

62. rizatriptan.mp.

63. zolmitriptan.mp.

64. almotriptan.mp.

65. eletriptan.mp.

66. frovatriptan.mp.

67. serotonin agonist?.mp.

68. ((5-hydroxytriptamine or 5-HT) adj2 agonist?).mp.

69. (antiemetic? or anti-emetic?).mp.

70. (antinauseant? or anti-nauseant?).mp.

71. thiethylperazin\$.mp.

72. trimethobenzamid\$.mp.

73. scopolamin\$.mp.

74. chlorpromazine.mp.

75. prochlorperazine.mp.

76. promethazin\$.mp.

77. perphenazin\$.mp.

78. trifluoperazin\$.mp.

79. met\#clopr\#mide.mp.

80. ondansetron.mp.

81. granisetron.mp.

82. dolasetron.mp.

83. diphenhydramine.mp.

84. hydroxyzine.mp. 
(Continued)

85. dimenhydrinate. $\mathrm{mp}$.

86. dronabinol.mp.

87. nabilone.mp.

88. fluid bolus.mp.

89. normal saline.mp.

90. magnesium.mp.

91. lidocaine.mp

92. corticosteroid\$.mp.

93. prednisolone.mp.

94. solumedrol.mp

95. dexamethason\$.mp.

96. hydrocortisol.mp.

97. exp methylprednisolone/

98. Botulinum Toxin Type A/

99. botulinium toxin.mp.

100. botox.mp.

101. oxygen.mp.

102. clonidine.mp.

103. diflunisal.mp.

104. (levomethadyl or levo-methadyl).mp.

105. remifentanil.mp.

106. ziconotid\$.mp.

107. placebo\$.mp.

108. (antimigrain\$ or anti-migrain\$).mp.

109. divalproex.mp.

110. methysergid\$.mp.

111. (ergoloid adj1 mesylate\$).mp.

112. (abortive adj3 (therap\$ or treatment\$)).mp.

113. or/6-112 $(335,914)$

114. and/5,113 $(6,616)$

Child related terms:

115. exp Infant/

116. exp Child/

117. Adolescent/ 
(Continued)

118. Minors/

119. exp Puberty/

120. exp Pediatrics/

121. infant\$.mp.

122. infancy.mp.

123. newborn\$.mp.

124. baby.mp.

125. babies.mp.

126. neonat\$.mp.

127. preterm\$.mp.

128. prematur\$.mp.

129. postmatur\$.mp.

130. child\$.mp.

131. kid.mp.

132. kids.mp.

133. toddler\$.mp.

134. adolescen\$.mp.

135. teen\$.mp.

136. boy\$.mp.

137. girl.mp.

138. minor\$.mp.

139. pubert\$.mp.

140. pubescen\$.mp.

141. prepubescen\$.mp.

142. pediatric\$.mp.

143. paediatric\$.mp.

144. peadiatric\$.mp.

145. or/115-144 $(136,786)$

146. and/114,145 [migraine + drugs + child] $(2,107)$

Removal of MEDLINE records:

147. limit 146 to medline records $(1,954)$

148. 146 not $147(153)$

Date limits for update: 
(Continued)

149. $\left(2008^{\star}\right.$ or $2009^{\star}$ or $\left.201^{\star}\right) \cdot u p .(671,470)$

150. and/148-149 [application of update code limit] (153)

151. limit 148 to latest update (2)

152. $\left(2012\right.$ jun ${ }^{\star}$ or $\left.2013^{\star}\right)$.up. [update code limit] $(27,314)$

153. new.uf. [update flag for new articles] $(30,970)$

154. (152 or 153) and 148 [application of update code and update flag to results] (10)

155. or/151,154 [combination of update results] (10)

Database Searched: Evidence Based Medicine Reviews via Ovid

Cochrane Database of Systematic Reviews <20(2005 to May 2012>, Database of Abstracts of Reviews of Effects <2nd Quarter 2012>

Search Title: Migraine Acute - L Richer - Update 3.2 | CCRT - 11 June 2012 - AM

Migraine related terms:

1. (migraine\$ or headache\$ or head-ache\$ or cephalgia or cephalalgia).mp. $(1,490)$

\section{Pharmaceutical related terms:}

2. (drug adj3 (therap\$ or treatment?)).mp.

3. ((anti-migrain\$ or antimigrain\$) adj3 (therap\$ or treatment?)).mp.

4. (treatment adj5 outcome).mp.

5. analgesi\$.mp.

6. "nonsteroidal anti-inflammatory agent?".mp.

7. "non-steroidal anti-inflammatory agent?".mp.

8. NSAID?.mp.

9. ibuprofen.mp.

10. fenoprofen.mp.

11. flurbiprofen.mp.

12. ketoprofen.mp.

13. ketorolac.mp.

14. diclofenac.mp.

15. etodolac.mp.

16. sulindac.mp.

17. diflunisal.mp.

18. naproxen.mp.

19. oxaprozin.mp. 
(Continued)

20. tiaprofenic acid.mp.

21. mefenamic acid.mp.

22. indomethacin.mp.

23. tolmetin.mp.

24. celecoxib.mp.

25. meloxicam.mp

26. piroxicam.mp.

27. tenoxicam.mp.

28. floctafenin\$.mp.

29. nabumeton\$.mp

30. acetaminophen.mp.

31. paracetamol.mp.

32. ergot\$ alkaloid?.mp.

33. ergotamin\$.mp.

34. dihydroergotoxin\$.mp.

35. dihydroergotamin\$.mp.

36. DHE.mp.

37. ergoloid mesylates.mp.

38. methysergide.mp.

39. ziconotide.mp.

40. opioid\$.mp

41. opiate\$.mp

42. opium.mp.

43. meperidine.mp.

44. alfentan\#l.mp.

45. fentan\#l.mp.

46. rem\#fentan\#l.mp.

47. sufentan\#l.mp.

48. levomethadyl.mp.

49. butorphanol.mp.

50. codein?.mp.

51. morphine.mp.

52. pentazocin\$.mp.

53. (propoxyphen\$ or dextro?propoxyphen\$).mp. 
(Continued)

54. nalbuphin\$.mp.

55. hydromorphon\$.mp.

56. oxycodon\$.mp.

57. oxymorphon\$.mp.

58. methadon\$.mp.

59. butalbital.mp.

60. aspirin.mp.

61. acetylsalicylic acid.mp.

62. caffeine.mp

63. "combination analgesic?".tw.

64. APAP.tw.

65. dichloralphenazone.mp.

66. isomethepten\$.mp.

67. corticosteroid\$.mp.

68. hydrocortisone.mp.

69. prednisolone.mp.

70. methylprednisolone.mp.

71. dexamethasone.mp.

72. tryptamin $\$ . m p$.

73. triptan?.mp.

74. sumatriptan.mp.

75. naratriptan.mp.

76. rizatriptan.mp.

77. zolmitriptan.mp.

78. almotriptan.mp.

79. eletriptan.mp.

80. frovatriptan.mp.

81. serotonin agonist?.mp.

82. ((5-hydroxytryptamine or 5-HT) adj2 agonist?).mp.

83. (antiemetic? or anti-emetic?).mp.

84. (antinauseant? or anti-nauseant?).mp.

85. chlorpromazine.mp.

86. prochlorperazine.mp.

87. perphenazine.mp. 
(Continued)

88. trifluoperazine.mp.

89. (met\#clopr\#mide or metochlopramide).mp.

90. scopolamin\$.mp.

91. dimenhydrinate.mp.

92. dronabinol.mp.

93. nabilon\$.mp.

94. thiethylperazine.mp.

95. trimethobenzamide.mp.

96. ondansetron.mp.

97. granisetron.mp

98. dolasetron.mp.

99. diphenhydramine.mp.

100. hydroxyzine.mp.

101. promethazine.mp.

102. Valproic Acid.mp.

103. valproate.mp.

104. divalproex sodium.mp.

105. Clonidine.mp.

106. fluid bolus.mp.

107. normal saline.mp.

108. magnesium.mp.

109. lidocaine.mp.

110. botulinium toxin.mp.

111. botox.mp.

112. oxygen.mp.

113. placebo\$.mp.

114. or/2-113 [migraine drugs] $(16,264)$

115. and/1,114 [combination of migraine + drugs] $(1,414)$

Child related terms:

116. infant\$.mp.

117. infancy.mp.

118. newborn\$.mp.

119. baby.mp.

120. babies.mp.

Drugs for the acute treatment of migraine in children and adolescents (Review) 
(Continued)

121. neonat\$.mp.

122. preterm\$.mp.

123. prematur\$.mp.

124. postmatur\$.mp.

125. child\$.mp.

126. kid.mp.

127. kids.mp.

128. toddler\$.mp.

129. adolescen\$.mp.

130. teen\$.mp.

131. boy\$.mp.

132. girl.mp.

133. girls.mp.

134. minor\$.mp.

135. pubert\$.mp.

136. pubescen\$.mp.

137. pediatric\$.mp.

138. paediatric\$.mp.

139. peadiatric\$.mp.

140. or/116-139 [child filter] $(9,102)$

141. and/115,140 [migraine + drug + RCT + child] (898)

142. remove duplicates from 141 (898)

Removal of articles which are protocols only:

143. limit 142 to protocols [Limit not valid in DARE; records were retained] (234)

144. 142 not $143(664)$

Date limits for update:

145. limit 144to last 5years (493)

146. $\left(2008^{\star}\right.$ or $2009^{\star}$ or $\left.201^{\star}\right) \cdot$ up. $(7,498)$

147. and/144,146 (664)

148. 145 or 147 (664)

Date limits for update 2013:

149. (2012 jun* or $\left.2013^{\star}\right) \cdot$.up. [update code limit] (859)

150. new.uf. [update flag for new articles] $(4,557)$ 
Database: International Pharmaceutical Abstracts via Ovid < 1970 to May $2012>$

Search Title: Migraine Acute - L Richer - Update 3.1|IPA - Keyword w/o pt terms - 11 June 2012 - AM

\section{Migraine related terms:}

1. (migraine\$ or headache\$ or head-ache\$ or cephalgia or cephalalgia).mp. $(3,917)$

Pharmaceutical related terms:

2. (drug adj3 (therap\$ or treatment?)).mp.

3. ((anti-migrain\$ or antimigrain\$) adj3 (therap\$ or treatment?)).mp.

4. (treatment adj5 outcome).mp.

5. analgesi\$.mp.

6. "nonsteroidal anti-inflammatory agent?".mp.

7. "non-steroidal anti-inflammatory agent?".mp.

8. NSAID?.mp.

9. ibuprofen.mp.

10. fenoprofen.mp.

11. flurbiprofen.mp.

12. ketoprofen.mp.

13. ketorolac.mp.

14. diclofenac.mp.

15. etodolac.mp.

16. sulindac.mp.

17. diflunisal.mp.

18. naproxen.mp.

19. oxaprozin.mp.

20. tiaprofenic acid.mp.

21. mefenamic acid.mp.

22. indomethacin.mp.

23. tolmetin.mp.

24. celecoxib.mp.

25. meloxicam.mp. 
(Continued)

26. piroxicam.mp.

27. tenoxicam.mp.

28. floctafenin\$.mp.

29. nabumeton\$.mp.

30. acetaminophen.mp.

31. paracetamol.mp

32. ergot\$ alkaloid?.mp

33. ergotamin\$.mp.

34. dihydroergotoxin\$.mp.

35. dihydroergotamin $\$ . m p$

36. DHE.mp.

37. ergoloid mesylates.mp.

38. methysergide.mp.

39. ziconotide.mp.

40. opioid\$.mp.

41. opiate\$.mp.

42. opium.mp.

43. meperidine.mp.

44. alfentan\#l.mp.

45. fentan\#l.mp.

46. rem\#fentan\#l.mp.

47. sufentan\#l.mp.

48. levomethadyl.mp.

49. butorphanol.mp.

50. codein?.mp.

51. morphine.mp.

52. pentazocin\$.mp.

53. (propoxyphen\$ or dextro?propoxyphen\$).mp.

54. nalbuphin\$.mp.

55. hydromorphon\$.mp.

56. oxycodon\$.mp.

57. oxymorphon\$.mp.

58. methadon\$.mp.

59. butalbital.mp. 
(Continued)

\section{0. aspirin.mp.}

61. acetylsalicylic acid.mp.

62. caffeine.mp.

63."combination analgesic?".tw.

64. APAP.tw.

65. dichloralphenazone.mp.

66. isomethepten\$.mp.

67. corticosteroid\$.mp.

68. hydrocortisone.mp.

69. prednisolone.mp.

70. methylprednisolone.mp.

71. dexamethasone.mp.

72. tryptamin\$.mp.

73. triptan?.mp.

74. sumatriptan.mp.

75. naratriptan.mp.

76. rizatriptan.mp.

77. zolmitriptan.mp.

78. almotriptan.mp.

79. eletriptan.mp.

80. frovatriptan.mp.

81. serotonin agonist?.mp.

82. ((5-hydroxytryptamine or 5-HT) adj2 agonist?).mp.

83. (antiemetic? or anti-emetic?).mp.

84. (antinauseant? or anti-nauseant?).mp.

85. chlorpromazine.mp.

86. prochlorperazine.mp.

87. perphenazine.mp.

88. trifluoperazine.mp.

89. (met\#clopr\#mide or metochlopramide).mp.

90. scopolamin\$.mp.

91. dimenhydrinate.mp.

92. dronabinol.mp.

93. nabilon\$.mp. 
(Continued)

94. thiethylperazine.mp.

95. trimethobenzamide.mp.

96. ondansetron.mp.

97. granisetron.mp.

98. dolasetron.mp.

99. diphenhydramine.mp.

100. hydroxyzine.mp.

101. promethazine.mp.

102. Valproic Acid.mp.

103. valproate.mp.

104. divalproex sodium.mp.

105. Clonidine.mp.

106. fluid bolus.mp.

107. normal saline.mp.

108. magnesium.mp.

109. lidocaine.mp.

110. botulinium toxin.mp.

111. botox.mp.

112. oxygen.mp.

113. placebo\$.mp.

114. or/2-113 [migraine drugs] $(97,647)$

\section{RCT filter:}

115. randomized.ab.

116. placebo.ab.

117. randomly.ab.

118. trial*.tw.

119. or/115-118 (59,621)

120. and/1,114,119 [combination of migraine + drugs + RCT terms] $(1,011)$

Child related terms:

121. infant\$.mp.

122. infancy.mp.

123. newborn\$.mp.

124. baby.mp. 
(Continued)

125. babies.mp.

126. neonat\$.mp.

127. preterm\$.mp.

128. prematur\$.mp.

129. postmatur\$.mp.

130. child\$.mp.

131. kid.mp.

132. kids.mp.

133. toddler\$.mp.

134. adolescen\$.mp.

135. teen\$.mp.

136. boy\$.mp.

137. girl.mp.

138. girls.mp.

139. minor\$.mp.

140. pubert\$.mp.

141. pubescen\$.mp.

142. pediatric\$.mp.

143. paediatric\$.mp.

144. peadiatric\$.mp.

145. or/121-144 [child filter] $(36,856)$

146. and/120,145 [migraine + drug + RCT + child] (109)

Date limits for update:

147. $\left(2008^{\star}\right.$ or $2009^{\star}$ or $\left.201^{\star}\right)$.ed,ep,up,yr. [entry date, e-pub date, update code, year of pub] $(87,846)$

148. 146 and $147(40)$

149. $\left(2012^{\star}\right.$ or $\left.2013^{\star}\right)$.em. [entry month date limit] $(27,810)$

150. and/146,149 [application of entry month date limit] (7)

Database: PsycINFO via Ovid < 1806 to June Week 12012 >

Search Title: Migraine Acute - L Richer - Update 4.0 | PsycINFO - 12 June 2012 - AM

\section{Migraine related terms:}



(Continued)
1. headache/
2. migraine/
3. muscle contraction headache/
4. (migraine\$ or headache\$ or head-ache\$ or cephalgia or cephalalgia).ti,ab.

5. or/1-4 $(15,618)$

Pharmaceutical related terms:

6. Drug Therapy/

7. exp drugs/

8. exp "side effects (drug)"/

9. (drug adj3 (therap\$ or treatment?)).mp.

10. ((anti-migrain\$ or antimigrain\$) adj3 (therap\$ or treatment?)).mp.

11. treatment outcomes/

12. (treatment adj5 outcome).mp.

13. analgesi\$.mp.

14. "nonsteroidal anti-inflammatory agent?".mp.

15. "non-steroidal anti-inflammatory agent?".mp.

16. NSAID?.mp.

17. ibuprofen.mp.

18. fenoprofen.mp.

19. flurbiprofen.mp.

20. ketoprofen.mp.

21. ketorolac.mp.

22. diclofenac.mp.

23. etodolac.mp.

24. sulindac.mp.

25. diflunisal.mp.

26. naproxen.mp.

27. oxaprozin.mp.

28. tiaprofenic acid.mp.

29. mefenamic acid.mp

30. indomethacin.mp.

31. tolmetin.mp.

32. celecoxib.mp.

33. meloxicam.mp. 
(Continued)

34. piroxicam.mp.

35. tenoxicam.mp.

36. floctafenin\$.mp.

37. nabumeton\$.mp.

38. acetaminophen.mp.

39. paracetamol.mp

40. ergot\$ alkaloid?.mp.

41. ergotamin\$.mp.

42. dihydroergotoxin $\$ . m p$

43. dihydroergotamin $\$ . m p$.

44. DHE.mp.

45. ergoloid mesylates.mp.

46. methysergide.mp.

47. ziconotide.mp.

48. opioid\$.mp.

49. opiate\$.mp.

50. opium.mp.

51. meperidine.mp.

52. alfentan\#l.mp.

53. fentan\#l.mp.

54. rem\#fentan\#l.mp.

55. sufentan\#l.mp.

56. levomethadyl.mp.

57. butorphanol.mp.

58. codein?.mp.

59. morphine.mp.

60. pentazocin\$.mp.

61. (propoxyphen\$ or dextro?propoxyphen\$).mp.

62. nalbuphin\$.mp.

63. hydromorphon\$.mp.

64. oxycodon\$.mp.

65. oxymorphon\$.mp.

66. methadon\$.mp.

67. butalbital.mp. 
(Continued)

68. aspirin.mp.

69. acetylsalicylic acid.mp.

70. caffeine.mp.

71. "combination analgesic?".tw.

72. APAP.tw.

73. dichloralphenazone.mp.

74. isomethepten\$.mp.

75. corticosteroid\$.mp.

76. hydrocortisone.mp.

77. prednisolone.mp.

78. methylprednisolone.mp.

79. dexamethasone.mp.

80. tryptamin\$.mp.

81. triptan?.mp.

82. sumatriptan.mp.

83. naratriptan.mp.

84. rizatriptan.mp.

85. zolmitriptan.mp.

86. almotriptan.mp.

87. eletriptan.mp.

88. frovatriptan.mp.

89. serotonin agonist?.mp.

90. ((5-hydroxytryptamine or 5-HT) adj2 agonist?).mp.

91. (antiemetic? or anti-emetic?).mp

92. (antinauseant? or anti-nauseant?).mp.

93. chlorpromazine.mp.

94. prochlorperazine.mp.

95. perphenazine.mp.

96. trifluoperazine.mp.

97. (met\#clopr\#mide or metochlopramide).mp.

98. scopolamin\$.mp.

99. dimenhydrinate. $\mathrm{mp}$.

100. dronabinol.mp.

101. nabilon\$.mp. 
(Continued)

102. thiethylperazine.mp.

103. trimethobenzamide.mp.

104. ondansetron.mp.

105. granisetron.mp.

106. dolasetron.mp.

107. diphenhydramine.mp.

108. hydroxyzine.mp.

109. promethazine.mp.

110. Valproic Acid.mp.

111. valproate.mp.

112. divalproex sodium.mp.

113. Clonidine.mp.

114. fluid bolus.mp.

115. normal saline.mp.

116. magnesium.mp.

117. lidocaine.mp.

118. botulinium toxin.mp.

119. botox.mp.

120. oxygen.mp.

121. placebo\$.mp.

122. or/6-121 [drug terms] $(310,358)$

\section{RCT filter:}

123. double-blind.tw.

124. random* assigned.tw.

125. control*.tw.

126. or/123-125 [HIRU max sensivity/specificity for RCTs] $(439,506)$

127. and/5,122,126 [sensivity/specificity filter] $(1,981)$

\section{Child related terms:}

128. infant\$.mp.

129. infancy.mp.

130. newborn\$.mp.

131. baby.mp.

132. babies.mp. 
(Continued)

133. neonat\$.mp.

134. preterm\$.mp.

135. prematur\$.mp.

136. postmatur\$.mp.

137. child\$.mp.

138. kid.mp.

139. kids.mp.

140. toddler\$.mp.

141. adolescen\$.mp.

142. teen\$.mp.

143. boy\$.mp.

144. girl.mp.

145. girls.mp.

146. minor\$.mp.

147. pubert\$.mp.

148. pubescen\$.mp.

149. pediatric\$.mp.

150. paediatric\$.mp.

151. peadiatric\$.mp.

152. or/128-151 $(717,968)$

153. and/127,152 [sensitivity/specificity filter] (255)

Date limits for update:

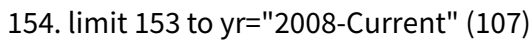

155. $\left(2008^{\star}\right.$ or $2009^{\star}$ or $\left.201^{\star}\right) \cdot y r$,dp,up. [year of publication, date of publication, update code search] $(803,770)$

156. and/153,155 [application of date limits] (147)

157. or/154,156 [ORing both date limits] (147)

158. (2012 jun ${ }^{\star}$ or $\left.2013^{\star}\right)$.dp,up. [date of publication, update code search] $(62,816)$

159. and/153,158 [application of date limits] (5)

Database: EMBASE via Ovid $<1980$ to present $>$

Search Title: Migraine Acute - L Richer - Update 2.0 | EMBASE - 8 June 2012 - AM 


\section{Migraine related terms:}

1. exp Headache Disorders/

2. vascular headache/

3. headache/

4. (migraine or headache\$ or head-ache\$ or cephalgia or cephalalgia).ti,ab.

5. or/1-4 (188,282)

Pharmaceutical related terms:

6. exp Drug Therapy/

7. (drug adj3 (therap\$ or treatment?)).mp.

8. ((anti-migrain\$ or antimigrain\$) adj3 (therap\$ or treatment?)).mp.

9. (ad or ae or dt or to).fs.

10. exp Treatment Outcome/

11. exp Analgesics/

12. "nonsteroidal anti-inflammatory agent?".mp.

13. "non-steroidal anti-inflammatory agent?".mp.

14. NSAID?.mp.

15. ibuprofen.mp.

16. fenoprofen.mp.

17. flurbiprofen.mp.

18. ketoprofen.mp.

19. ketorolac.mp.

20. diclofenac.mp.

21. etodolac.mp.

22. sulindac.mp.

23. diflunisal.mp.

24. naproxen.mp.

25. oxaprozin.mp.

26. tiaprofenic acid.mp.

27. mefenamic acid.mp.

28. indomethacin.mp.

29. tolmetin.mp.

30. celecoxib.mp.

31. meloxicam.mp. 
(Continued)

32. piroxicam.mp.

33. tenoxicam.mp.

34. floctafenin\$.mp.

35. nabumeton\$.mp.

36. acetaminophen.mp.

37. paracetamol.mp

38. ergot\$ alkaloid?.mp

39. ergotamin\$.mp.

40. dihydroergotoxin\$.mp.

41. dihydroergotamin $\$ . m p$.

42. DHE.mp.

43. ergoloid mesylates.mp.

44. methysergide.mp.

45. ziconotide.mp.

46. opioid\$.mp.

47. opiate\$.mp.

48. opium.mp.

49. meperidine.mp.

50. alfentan\#l.mp.

51. fentan\#l.mp.

52. rem\#fentan\#l.mp.

53. sufentan\#l.mp.

54. levomethadyl.mp.

55. butorphanol.mp.

56. codein?.mp.

57. morphine.mp.

58. pentazocin\$.mp.

59. (propoxyphen\$ or dextro?propoxyphen\$).mp.

60. nalbuphin\$.mp.

61. hydromorphon\$.mp.

62. oxycodon\$.mp.

63. oxymorphon\$.mp.

64. methadon\$.mp.

65. butalbital.mp. 
(Continued)

66. aspirin.mp.

67. acetylsalicylic acid.mp.

68. caffeine.mp.

69. "combination analgesic?".tw.

70. APAP.tw.

71. dichloralphenazone.mp.

72. isomethepten\$.mp.

73. corticosteroid\$.mp.

74. hydrocortisone.mp.

75. prednisolone.mp.

76. methylprednisolone.mp.

77. dexamethasone.mp.

78. tryptamin\$.mp.

79. triptan?.mp

80. sumatriptan.mp.

81. naratriptan.mp.

82. rizatriptan.mp.

83. zolmitriptan.mp.

84. almotriptan.mp.

85. eletriptan.mp.

86. frovatriptan.mp.

87. serotonin agonist?.mp.

88. ((5-hydroxytryptamine or 5-HT) adj2 agonist?).mp.

89. (antiemetic? or anti-emetic?).mp.

90. (antinauseant? or anti-nauseant?).mp.

91. chlorpromazine.mp.

92. prochlorperazine.mp.

93. perphenazine.mp.

94. trifluoperazine.mp.

95. (met\#clopr\#mide or metochlopramide).mp.

96. scopolamin\$.mp.

97. dimenhydrinate.mp.

98. dronabinol.mp.

99. nabilon\$.mp. 
(Continued)

100. thiethylperazine.mp.

101. trimethobenzamide.mp.

102. ondansetron.mp.

103. granisetron.mp.

104. dolasetron.mp.

105. diphenhydramine.mp.

106. hydroxyzine.mp.

107. promethazine.mp.

108. Valproic Acid.mp.

109. valproate.mp.

110. divalproex sodium.mp.

111. Clonidine.mp.

112. fluid bolus.mp.

113. normal saline.mp.

114. magnesium.mp.

115. lidocaine.mp.

116. Botulinum Toxin Type A/

117. botulinium toxin.mp.

118. botox.mp.

119. oxygen.mp.

120. placebo\$.mp.

121. or/6-120 [combination of all possible pharmaceutical treatments for migraine] $(5,743,355)$

\section{RCT filter:}

122. random*.tw

123. placebo*.mp.

124. double-blind ${ }^{*}$. tw.

125. or/122-124 [RCT filter from J Med Libr Assoc 2006] (907,731)

\section{Child related terms:}

126. adolescent/

127. child/

128. newborn/

129. exp Pediatrics/

130. infant\$.mp. 
(Continued)

131. infancy.mp.

132. newborn\$.mp.

133. baby.mp.

134. babies.mp.

135. neonat\$.mp.

136. preterm\$.mp.

137. prematur\$.mp.

138. postmatur\$.mp.

139. child\$.mp.

140. kid.mp.

141. kids.mp.

142. toddler\$.mp.

143. adolescen\$.mp.

144. teen\$.mp.

145. juvenile\$.mp.

146. boy\$.mp.

147. girl.mp.

148. girls.mp.

149. minor\$.mp.

150. pubert\$.mp.

151. pubescen\$.mp.

152. pediatric $\$ . m p$.

153. paediatric $\$ . m p$.

154. peadiatric $\$ . m p$.

155. or/126-154 [child filter as per original search]

156. and $/ \mathbf{5 , 1 2 1 , 1 2 5 , 1 5 5}$ [combination of migrain + drugs + RCT + child] $(6,357)$

157. $\left(2008^{\star}\right.$ or $2009^{\star}$ or $\left.201^{\star}\right)$.dp,em,yr. [date of publication, entry date, year of publication limits] $(4,936,810)$

158. and/156-157 [application of date limits] $(2,884)$

Update search limits for 2013:

159. $\left(2012\right.$ jun* or $\left.2013^{\star}\right) \cdot d p$. [date of publication limit] $(24,334)$

160. $\left(20122^{\star}\right.$ or $20123^{\star}$ or $20124^{\star}$ or $20125^{\star}$ or $\left.2013^{\star}\right)$.em. [entry date limit] $(1,247,362)$

161. (or/159-160) and 156 [application of date limits] (508) 
Database: CINAHL Plus with Full Text via Ebsco $<1937$ to present $>$

Search Title: Pediatric Migraine - CINAHL - Update - 12 June 2012 - AM

Limiters - Published Date from: 20120601-20130531 (31)

S17=S16 Limiters - Published Date from: 20080101-20120631 (263)

S16=S1 and S2 and S14 and S15 (712)

Child related terms:

S15=((MH "Infant+") or (MH "Child+") or (MH "Adolescence") or (MH "Puberty+") or (MH "Pediatrics+") or infant* or infanc* or newborn* or baby or neonat ${ }^{\star}$ or preterm* or prematur ${ }^{\star}$ or postmatur ${ }^{\star}$ or child* or kid or kids or toddler ${ }^{\star}$ or adolescen* or teen* or boy ${ }^{\star}$ or girl or girls* or minor ${ }^{\star}$ or pubert* or pubescen $^{\star}$ or pediatric ${ }^{\star}$ or paediatric or peadiatric $\left.^{\star}\right)(601,431)$

$\mathbf{S} 14=\mathbf{S} 3$ or $\mathbf{S} 4$ or $\mathbf{S} 5$ or $\mathbf{S 6}$ or $\mathbf{S 7}$ or $\mathbf{S} 8$ or $\mathbf{S} 9$ or $\mathbf{S 1 0}$ or $\mathbf{S 1 1}$ or $\mathbf{S 1 2}$ or $\mathbf{S 1 3}(807,111)$

\section{RCT filter:}

$\mathrm{S} 13=\mathrm{TX}$ allocat ${ }^{*}$ random*

S12=MH "Quantitative Studies"

S11=(MH "Placebos")

$\mathrm{S} 10=\mathrm{TX}$ placebo*

$\mathrm{S} 9=\mathrm{TX}$ random ${ }^{*}$ allocat ${ }^{*}$

S8=(MH "Random Assignment")

$\mathrm{S} 7=\mathrm{TX}_{\mathrm{randomi}}{ }^{*}$ control $^{\star}$ trial $^{\star}$

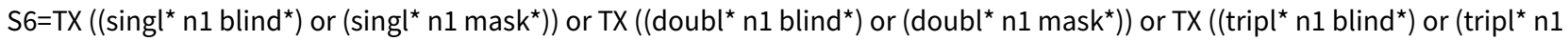
mask $\left.\left.^{\star}\right)\right)$ or TX ((trebl* n1 blind $\left.{ }^{\star}\right)$ or (trebl* n1 mask $\left.\left.{ }^{\star}\right)\right)$

$\mathrm{S} 5=$ TX $_{\text {clinic }}^{*} \mathrm{n} 1$ trial $^{\star}$

S4=PT Clinical trial

S3=(MH "Clinical Trials+")

Pharmaceutical related terms:

S2=( (MH "Drug Therapy+") or (MH "Drug Therapy, Combination+") or (MH "Drug Combinations+") or (MH "Drug Therapy+") or MH "Drug Therapy, Combination+" or MH "Drug Combinations+" or drug w3 therap* or drug w3 treatment* or anti-migrain* w3 therap* or antimigrain* w3 treatment* or (MH "Treatment Outcomes+") or (MH "Analgesics+") or "nonsteroidal anti-inflammatory agent?" or "non-steroidal anti-inflammatory agent?" or ibuprofen or fenoprofen or flurbiprofen or Ketorolac or Diclofenac or Etodolac or Sulindac or Diflunisal or Naproxen or Oxaprozin or "tiaprofenic acid" or "mefenamic acid" or Indomethacin or Tolmetin or Celecoxib ) or ( Meloxicam or Piroxicam or Tenoxicam or Floctafenin* or nabumeton* or acetaminophen or ergot* w1 alkaloid* or ergotamin* or dihydroergotoxin ${ }^{\star}$ or dihydroergotamin ${ }^{\star}$ or DHE or ergoloid w1 mesylates or methysergide or ziconotide or opioid* or opiate* ) or ( opium or alfentan?l or fentan?l or rem?fentan?l or sufentan?l or levomethadyl or butorphanol or codein* or morphine or pentazocin* or propoxyphen $^{\star}$ or dextro-propoxyphen* or dextropropoxyphen ${ }^{\star}$ or nalbuphin ${ }^{\star}$ or hydromorphon ${ }^{*}$ or oxycodon ${ }^{\star}$ ) (425780)

\section{Migraine related terms:}

$\mathrm{S} 1=\left(\mathrm{MH}\right.$ "Headache+" or MH "Vascular Headache+" ) or $\mathrm{Tl}$ ( migraine ${ }^{\star}$ or headache* or head-ache* or cephalgia or cephalalgia ) or AB ( migraine* or headache* or head-ache* or cephalgia or cephalalgia) $(18,833)$ 
WHAT' S NEW

\begin{tabular}{lll}
\hline Date & Event & Description \\
\hline 29 October 2020 & Review declared as stable & See Published notes. \\
\hline
\end{tabular}

\section{H I S T O R Y}

Protocol first published: Issue 2, 2005

Review first published: Issue 4, 2016

\begin{tabular}{lll}
\hline Date & Event & Description \\
\hline 17 October 2018 & Review declared as stable & See Published notes. \\
\hline 1 September 2010 & Feedback has been incorporated & $\begin{array}{l}\text { Incorporated feedback from Editorial review and updated } \\
\text { search. }\end{array}$ \\
\hline 15 May 2008 & Amended & Converted to new review format. \\
\hline
\end{tabular}

\section{CONTRIBUTIONS OF AUTHORS}

Lawrence Richer - protocol development, review of publications, data entry, analysis, report writing, presentation of findings, updates to report.

Meghan Linsdell - review of publications, data abstraction, data entry, review of report, updates to report.

Lori Billinghurst - protocol development, review and selection of publications, presentation of findings.

Kelly Russell - data abstraction, report writing, review of report.

Ben Vandermeer - data abstraction, statistical analysis, report writing.

Tamara Durec and Ellen Crumley - development of publication database search.

Lisa Hartling - protocol development, review of report.

Terry Klassen - protocol development, review of report.

\section{DECLARATIONS OF INTEREST}

Lawrence Richer: no relevant conflicts of interest to declare.

Lori Billinghurst: no relevant conflicts of interest to declare.

Kelly Russell: no relevant conflicts of interest to declare.

Ben Vandermeer: no relevant conflicts of interest to declare.

Tamara Durec: no relevant conflicts of interest to declare.

Ellen Crumley: no relevant conflicts of interest to declare.

Lisa Hartling: no relevant conflicts of interest to declare. 
Terry Klassen: no relevant conflicts of interest to declare.

Meghan Linsdell: no relevant conflicts of interest to declare.

\section{SOURCESOF SUPPORT}

\section{Internal sources}

- Department of Pediatrics, University of Alberta, Canada

- Alberta Research Centre for Child Health Evidence, Canada

\section{External sources}

- Stollery Children's Hospital Foundation, Canada

- American Academy of Pediatrics Resident Research Grant, USA

\section{DIFFERENCES BETWEEN PROTOCOL AND REVIEW}

- At the recommendation of the Cochrane Pain, Palliative and Supportive Care Group, we narrowed the review criteria to include only placebo-controlled trials. We did not include studies with active comparators or standard of care as the control.

- The original protocol outlined a plan to address possible carry-over and period effects in studies of cross-over design. Given that migraine is an episodic disorder and that interventions were used to treat discrete migraine episodes, we considered the probability of there being carry-over and period effects to be very low. Thus, we deemed it inappropriate to exclude studies of cross-over design as suggested in the Cochrane Handbook for Systematic Reviews of Interventions. We included all studies of cross-over design even if they did not report the time between treatment periods or a statistical test for carry-over effect. We performed a sensitivity analysis on study design to assess the influence of cross-over studies on measures of effect and harm.

- We changed the allowed ages from the range of 3 to 18 years to any age under 18 . For the subgroup analysis, we defined age groups according to custom in these types of studies (i.e. children less than 12 years of age; adolescents 12 to 17 years), as these age groups represent distinct ages whereby treatment may differ. No minimum age was included, as the diagnosis of migraine using appropriate criteria will preclude diagnosis in the very young, in whom criteria are not met.

- All studies reported the treatment of a single attack. The original protocol outlined a plan to address studies that reported the treatment of multiple headache episodes, but it was not necessary to implement this. If required, we will apply this plan in future revisions of the study.

- We added 'pain-free' as the primary outcome measure, given that it is a recommended primary outcome measure (Tfelt-Hansen 2012), it is the most desirable outcome for patients, and most studies report it.

- We changed 'headache relief' from a primary to a secondary outcome measure.

- No studies reported ordinal outcomes, continuous outcomes, or group mean change scores. Thus, we did not implement these aspects of the protocol, but we will if required in future revisions of the review.

- We removed photophobia and phonophobia from secondary outcome measures as recommended by reviewers and often only inferred from behaviour.

- We removed patient preference for treatment as a secondary outcome measure.

- We did not include assessment time points beyond two hours post medication administration given the known relatively short duration of migraine in many children and adolescents.

- We included a primary outcome measure to assess harm (i.e. any adverse events), as per the updated version 5.1.0 of the Cochrane Handbook for Systematic Reviews of Interventions (Higgins 2011).

- We revised the search strategy to improve search terms and focus on pharmacological interventions.

- We did not include a high versus low methodological quality score based on the Jadad scale in the sensitivity analysis, as we used the 'Risk of bias' tables to assess methodological quality. We used allocation concealment as per the protocol, as it is one of the domains in the 'Risk of bias' assessment.

- We added the GRADE assessment of quality of evidence.

- The original protocol proposed calculating within-patient improvement scores whenever the required data were reported, but these were not available.

- We added reports in a peer-reviewed indexed journal to the sensitivity analysis.

- We did not identify or include any quasi-randomized studies in the review. Future revisions of the review would not benefit from their inclusion, so we removed this selection criterion as suggested by reviewers.

- We amended the title from "Drugs for treating acute migraine headaches in children and adolescents" to "Drugs for the acute treatment of migraine in children and adolescents" for clarity. 


\section{NOTES}

This systematic review has not previously been published in full form. The data have been presented at the American Headache Society Annual Scientific meeting.

\section{Assessed for updating in 2018}

A full search was performed in February 2018 and after screening the results the authors did not identify any potentially relevant studies. At October 2018, this review has been stabilised following discussion with the authors and editors. New treatments for migraine are anticipated, and we will update the review if new evidence likely to change the conclusions is published, or if standards change substantially which necessitate major revisions.

\section{Assessed for updating in 2020}

At October 2020 we are not aware of any potentially relevant studies likely to change the conclusions, although this is an active area of research and new studies are expected in the next two to three years. Following discussion with the authors and editors, this review has now been stabilised and will be reassessed for updating in two years. If appropriate we will update the review sooner if new evidence likely to change the conclusions is published, or if standards change substantially which necessitates major revisions.

\section{INDEX TERMS}

\section{Medical Subject Headings (MeSH)}

Acetaminophen [therapeutic use]; Analgesics, Non-Narcotic [ ${ }^{\star}$ therapeutic use]; Dihydroergotamine [therapeutic use]; Ibuprofen [therapeutic use]; Migraine Disorders [ ${ }^{*}$ drug therapy]; Serotonin Receptor Agonists [adverse effects] [*therapeutic use]; Time Factors; Tryptamines [*therapeutic use]

\section{MeSH check words}

Adolescent; Child; Humans 